\title{
Expertise in accountancy : empirisch onderzoek naar de kennisontwikkeling van student tot ervaren accountant
}

Citation for published version (APA):

Vaatstra, H. F. (1996). Expertise in accountancy : empirisch onderzoek naar de kennisontwikkeling van student tot ervaren accountant. [Doctoral Thesis, Maastricht University]. Universiteit Maastricht. https://doi.org/10.26481/dis.19961223hv

Document status and date:

Published: 01/01/1996

DOI:

10.26481/dis.19961223hv

Document Version:

Publisher's PDF, also known as Version of record

Please check the document version of this publication:

- A submitted manuscript is the version of the article upon submission and before peer-review. There can be important differences between the submitted version and the official published version of record.

People interested in the research are advised to contact the author for the final version of the publication, or visit the DOI to the publisher's website.

- The final author version and the galley proof are versions of the publication after peer review.

- The final published version features the final layout of the paper including the volume, issue and page numbers.

Link to publication

\footnotetext{
General rights rights.

- You may freely distribute the URL identifying the publication in the public portal. please follow below link for the End User Agreement:

www.umlib.nl/taverne-license

Take down policy

If you believe that this document breaches copyright please contact us at:

repository@maastrichtuniversity.nl

providing details and we will investigate your claim.
}

Copyright and moral rights for the publications made accessible in the public portal are retained by the authors and/or other copyright owners and it is a condition of accessing publications that users recognise and abide by the legal requirements associated with these

- Users may download and print one copy of any publication from the public portal for the purpose of private study or research.

- You may not further distribute the material or use it for any profit-making activity or commercial gain

If the publication is distributed under the terms of Article $25 \mathrm{fa}$ of the Dutch Copyright Act, indicated by the "Taverne" license above, 


\section{Expertise in \\ Accountancy}

Empirisch onderzoek naar

de kennisontwikkeling van

student tot ervaren accountant 
Omslagontwerp:

Jannie Damstra, bnd Plano, Vleuten

Drukwerk:

Datawyse I Universitaire Pers Maastricht

CIP-gegevens Koninklịke Bibliotheek, Den Haag

Vaatstra, Hendrina Fokalien

Expertise in Accountancy: Empirisch onderzoek naar de kennisontwikkeling van student tot ervaren accountant / Hendrina Fokalien Vaatstra. - Maastricht: Universitaire Pers Maastricht. - III. Proefschrift Maastricht. - Met lit. opg. - Met Engelse samenvatting. ISBN 90-9010065-2

Trefwoorden: expertise / accountancy / kennisontwikkeling 


\section{Expertise in Accountancy}

Empirisch onderzoek naar de kennisontwikkeling van student tot ervaren accountant

\section{Proefschrift}

Ter verkrijging van de graad van doctor aan de Universiteit Maastricht,

op gezag van de Rector Magnificus, Prof. mr. M. J. Cohen volgens het besluit van het College van Decanen, in het openbaar te verdedigen op maandag. 23 december 1996 om 14.00 uur

door

Hendrina Fokalien Vaatstra 
Promotores:

Prof. dr. H.G. Schmidt.

Prof. dr. A. Schilder RA

Co-promotor:

Dr. H.P.A. Boshuizen

Beoordelingscommissie:

Prô. dr. A. van Witteloostuijn (voorzitter)

Prof. dr. W. Buijink

Prof. dr. J. Pleters (Universiteit Twente)

Dr. E. Vaassen RA

Prof. dr. Ph. Wallage RA (Universiteit van Amsterdam) 
Voor mijn ouders 



\section{Inhoudsopgave}

Inleiding 1

1 Professie en Opleiding, 3

Ontstaan van de professie 3

Van boekhouder naar accountant 4

Accountancy-organisaties $\quad 5$

$\begin{array}{ll}\text { Opleidingsmogelijkheden } & \mathbf{7}\end{array}$

Van NIVA naar NIVRA $\quad 8$

Huidige Taken 9

Controle van de jaarrekening $\quad 11$

$\begin{array}{ll}\text { Het accountantsteam } & 16\end{array}$

Opleidingen tot Registeraccountant $\quad 17$

$\begin{array}{ll}\text { Vergelijking van Opleidingen } & 27\end{array}$

2 De invloed van praktijkervaring oftewel 31

de ontwikkeling van expertise

Inleiding 31

Expertise 31

Studies vanuit Brunswik's Lensmodel 33

Studies naar de rol van heuristieken $\quad 36$

$\begin{array}{ll}\text { Studies naar het cognitieve redeneerproces } & 39\end{array}$

Studies naar kennis en kennisstructuur 46

Studies naar kennis en kennisstructuur bij accountants. 51

Conclusies en Onderzoeksvragen $\quad 63$

3 Een recall-studie $\quad 65$

Inleiding $\quad 65$

Onderzoekmethode $\quad 69$

$\begin{array}{ll}\text { Resultaten } & 73\end{array}$

Discussie en Conclusies $\quad 82$ 
4 Een hardopdenk-studie $\quad 87$

$\begin{array}{ll}\text { Inleiding } & 87\end{array}$

$\begin{array}{ll}\text { Onderzoekmethode } & 91\end{array}$

Resultaten 94

$\begin{array}{ll}\text { Discussie en Conclusies } & 101\end{array}$

5 Een kennistoets-studie $\quad 107$

$\begin{array}{ll}\text { Inleiding } & 107\end{array}$

Onderzoekmethode $\quad 110$

$\begin{array}{ll}\text { Resultaten } & 112\end{array}$

$\begin{array}{ll}\text { Discussie en Conclusies } & 117\end{array}$

6 Samenvatting, Conclustes \& Implicatles 123

Samenvatting 123

Conclusies 133

Discussie 136

$\begin{array}{ll}\text { Implicaties } & 137\end{array}$

$\begin{array}{ll}\text { Summary } & 145\end{array}$

Referenties $\quad 155$

$\begin{array}{ll}\text { Bijlage 1 } & 165\end{array}$

Bijlage 2 169

Bijlage $3 \quad 171$

$\begin{array}{ll}\text { Bijlage 4 } & 177\end{array}$

$\begin{array}{ll}\text { Dankwoord } & 181\end{array}$

$\begin{array}{ll}\text { Curriculum Vitae } & 183\end{array}$ 
De gedachte om empirisch onderzoek te verrichten naar de ontwikkeling van accountancy-expertise is eind jaren tachtig ontstaan naar aanleiding van gesprekken tussen prof. dr. A. Schilder en dr. W. Gijselaers over onderwijsvernieuwing in de accountancy-opleiding. Het proefschrift van Boshuizen (1989) 'De ontwikkeling van medische expertise' zorgde ervoor dat de reeds gewekte interesse van accountants in de ontwikkeling van expertise werd versterkt. Deze combinatie van factoren heeft geleid tot een projectvoorstel waarvan dit proefschrift het eindresultaat is.

De centrale vraag die in het projectvoorstel naar voren kwam, was of de ontwikkeling van expertise bij accountants vergelijkbaar is met de ontwikkeling van expertise in andere domeinen zoals bijvoorbeeld in de geneeskunde. Alhoewel veel mensen het medische domein misschien moeilijk te vergelijken vinden met het accountancydomein zien vooraanstaande onderzoekers als Ashton, Kleinmuntz, Sullivan en Tomassini (1988) een duidelijke gelijkenis tussen de medische- en de accountancyprofessie. Volgens deze onderzoekers bestaat beider taak uit diagnostiseren, met dit verschil dat de taak van artsen bestaat uit het diagnostiseren van patięnten. terwijl de taak van accountants is bedrijven en ondernemingen te diagnostiseren.

Om een beeld te krijgen van de inhoud van dit proefschrift worden hieronder de verschillende hoofistukken kort beschreven.

Het eerste hoofdstuk 'Professie en Opleiding' dient voornamelijk als context voor de rest van het proefschrift. Het doe! van dit hoofdstuk is iezers die weinig afweten van het accountancydomein een kort overzicht te geven van wat het accountancyberoep globaal gezien inhoudt. Daartoe wordt eerst een historische schets van het ontstaan van het accountantsberoep gegeven. Vervolgens worden de huidige taken van accountants besproken. Deze bespreking van de huidige taken gebeurt op zo'n manier dat het ook voor leken op het gebied van accountancy begrijpelijk is. Het hoofdstuk besluit met een beschrijving van de Registeraccountancy-opleidingen: HEAO, NIVRA/Nijenrode en 'reguliere' universiteiten. Om de lezer een overzicht te geven van de inhoud van de verschillende opleidingsmogelijkheden zijn de daar gedoceerde vakken kort samengevat. 
In Hoofdstuk 2 is nagegaan wat in de literatuur tot nu toe bekend was over de invloed van praktijkervaring en de ontwikkeling van expertise op het terreln van de accountancy. Het hoofdstuk begint met een uiteenzetting van wat in dit proefschrift onder expertise zal worden verstaan. Daarna worden achtereenvolgens de volgende onderzoeksstromingen besproken: studies vanuit Brunswik's Lensmodel, studies naar heuristieken, studies naar het cognitieve redeneerproces en studies naar de relatie tussen expertise-niveau en kennis en kennisstructuur. Het hoofdstuk eindigt met een aantal conclusies en onderzoeksvragen die in de hoofdstukken 3, 4 en 5 worden getoetst.

In Hoofdstuk 3 wordt de eerste empirische studie beschreven. Daarin is onderzocht of ervaren accountants beter zijn in het signaleren van knelpunten bij een bedrijf dan minder ervaren accountants. Tevens is met behulp van de 'recall' methode nagegaan of ervaren accountants meer en andersoortige kennis bezitten dan minder ervaren accountants. Bovendien is onderzocht of ervaren accountants relevante informatie sneller verwerken dan minder ervaren accountants. Aan het onderzoek hebben vijf groepen deeigenomen die verschilden qua expertise-niveau.

In de tweede studie (Hoofdstuk 4) is getracht aan de hand van hardopdenk-protocollen de soorten kennis die accountants gebrulken tijdens het doornemen van informatie over een bedrijf, in kaart te brengen. Aan het onderzoek hebben vier groepen variërend in expertise-niveau deelgenomen.

In Hoofdstuk 5 wordt de derde en tevens laatste studie beschreven. In die studie is met behulp van een kennistoets onderzocht of de geconstateerde relatie tussen expertise-niveau en soort kennis uit de twee empirische studies beschreven in Hoofdstuk 3 en 4, kan worden gespecificeerd. De taak bestond uit vragen over causale verbanden tussen financiële gegevens uit een jaarrekening. Aan het onderzoek hebben wederom vier groepen deelgenomen die verschilden qua expertise-niveau.

In Hoofdstuk 6 worden de vijf hoofdstukken nog eens kort samengevat. Vervolgens worden de getrokken conclusies beschreven en worden enkele beperkingen van de uitgevoerde studies weergegeven. Het hoofdstuk eindigt met adviezen die voor het accountancy-onderwijs en de praktijk van belang zijn. 


\section{Professie en Opleiding}

In dit hoofdstuk zal allereerst worden beschreven hoe het accountantsberoep is ontstaan, wat men er aan het begin van deze eeuw onder verstond en wat het beroep tegenwoordig inhoudt. Daarbij moet worden opgemerkt dat de beschrijuing van de werkzaamheden met name is bedoeld voor diegenen die weinig weten van accountancy. Vervolgens zullen de huidige verschillende opleidingsmogelijkheden worden besproken en vergeleken. $B \dot{y}$ het bespreken van deze opleidingen zal de inhoud van de verplichte cursussen kort worden samengevat.

\section{Ontstan van de professie}

In de tweede helft van de negentiende eeuw deden zich een aantal belangrijke ontwikkelingen in de Nederlandse economie voor. De sterke groei van de handel, het bank- en verzekeringswezen, de scheepvaart en de agrarische export brachten een steeds groter wordende hoeveelheid geld in omloop. Daarnaast werden er steeds meer Naamloze Vennootschappen opgericht waarbij een scheiding van beheer en eigendom verplicht was. Beide ontwikkelingen zorgden ervoor dat er vraag naar externe onafhankelijke personen ontstond die de beheerders van het grote kapitaal in opdracht van de bezitters moesten controleren (De Vries, 1985).

Een grote fraude in 1879 liet zien dat het inderdaad tijd werd om bij Naamloze Vennootschappen externe controles uit te laten voeren. In deze fraudezaak was het volgende het geval: één van de ondernemingen van de heer Pincoff, de N.V. Afrikaansche Handelsmaatschappij had in de jaren zeventig behoorlijke verliezen. geleden. Pincoff had twee interne boekhouders onder druk gezet om de boekhouding dusdanig te flatteren dat er in plaats van acht miljoen verlies, twee miljoen winst op de balans kwam te staan. De controlerende commissarissen waren er vanuit gegaan dat zowel de balans als de boeken in orde zouden zijn bij iemand die zo'n aanzien genoot als Pincoff. Een van de commissarissen, mr. M. Mees, ontdekte echter in 1879 een korte buitenlandse lening en rook onraad. Na een nauwkeurige inspectie 
van alle boeken werd er tevens een fraude van fl. 2,8 miljoen gevonden (De Vries, 1985).

Kortom, de maatschappelijke en economische ontwikkelingen tegen het einde van de negentiende eeuw resulteerden erin dat boekhouders geinteresseerd raakten in de specifieke administratieve problemen die deze ontwikkelingen met zich meebrachten.

\section{Van boekhouder naar accountant}

In 1883 werd te Rotterdam het eerste bureel van boekhouding 'Confidentia' opgericht. Uit een brochure van Confidentia uit 1891 kan worden afgelezen dat de taken van de boekhouders van Confidentia vrij sterk overeenkwamen met wat men later accountancywerkzaamheden zou gaan noemen. De nadruk lag in die tijd in de eerste plaats in het opzetten en beheren van administraties en pas daarna op de controle van administraties. De werkzaamheden die onder andere werden beschreven in die brochure, waren:

-het byhouden van koopmansboeken, het bywerken van achterstallige boeker, het aanleggen van boeken in nieuw opgerichte zaken en in die waarin een vereenvoudigde of verbeterde boekhouding werd verlangd;

chet controleren van filialen in andere plaatsen en het opmaken der balans in onderling verband;

-het opmaken van actief en passief van een furma die tijdelijk stagneerde;

het uitwerken voor arbiters van geschilpurten bij verwikkelingen tussen vennoten:

-het bighouden van de particuliere administratie en het opmaken van de balans voor byvoorbeeld kooplieden, winkeliers en industriëlen;

-het uitoefenen van controle op administraties, waarbij lastgevers geünteresseerd waren.

(De Bruyne, 1980; De Vries, 1985).

Om als medewerkers van Confldentia te kunnen optreden was het een vereiste om de Acte M.O. Boekhouden en Handelsrekenen te hebben en in de praktijk als administrateur of boekhouder te werken. In de beginfase van het bureel werden de werkzaamheden van de leden nog naast hun dagelijkse werk als administrateur of als boekhouder uitgevoerd. Na 1890 kwam daar, 
vanwege grote belangstelling voor deze werkzaamheden, verandering in en kon men er volledig van rondkomen. De boekhoudkundige voorlichting en administratieve controle werd toen een zelfstandig beroep.

Naarmate er meer belangstelling kwam voor zo'n bureel van boekhouding werd men minder tevreden over de term 'boekhouder'. De taken die de boekhouders van het bureel verrichtten waren toch van een andere aard dan het boekhoudkundige, administratieve werk wat ze daarvoor gedaan hadden als interne boekhouder van een bedrijf. Dankzij de contacten van Van Dien, Volmer en Korthals Altes met Engelse accountants werd de titel 'accountant' in 1893 door Van Dien in Nederland geintroduceerd. Van Dien, Volmer en Korthals Altes waren van mening dat de Engelse titel 'accountant' beter aansloot op het totale arsenaal van werkzaamheden dat zij verrichtten dan de beperktere termen 'boekhouder', 'controleur' of 'administrateur'. Echter niet iedereen stond achter het gebruik van de titel 'accountant' en het duurde dan ook een aantal jaren voordat de term werkelijk ingeburgerd was.

\section{Accountancy-organisaties}

Vanwege de grote vraag naar accountants kwamen er in de jaren $1893 / 1894$ steeds meer personen die zich voor accountant uitgaven. De. angst dat ook onbevoegden als zodanig zouden kunnen optreden en daardoor het pas ontstane beroep schade zouden kunnen toebrengen heeft geleid tot de oprichting van enkele accountancy-organisaties. De opzet was dat de organisatie zorg zou moeten dragen voor de vorming en de bescherming van het nieuwe beroep.

Op 1 januari 1895 werd de eerste organisatie voor accountants opgericht: het Nederlandsche Instituut van Accountants (NIVA). In het tijdschrift van het NIVA "de Accountant" van jull 1895 wordt het beroep als volgt geïntrođuceerd (NIVRA, 1983, p. 3):

[.... Hier heeft men te doen, niet met een zelfstandig accountant, die kwallyk zich zelve kan aanbevelen, ook noch met een 'Bureel van Boekhouding' dat van elgen voordeel zoeken bij iedere reclame, hoe onschuldig ook, kan verdacht worden, maar met eene instelling, die als zoodanig geen winst of voordeel beoogt $[\ldots . .$.$] Het$ eigenbelang zit hier dus niet op den troon, en dit mocht ook niet zijn, wilde althans 
eene combinatie van beroepsgenoten mogelijk wezen, die toch immers elkanders mededingers blijven. Zooveel te meer rijst daarmede ook hun invloed. Men kan intusschen anders meer zien, dan eene gemeenschappelijke poging der Nederlandsche administratieve experts, om in het. algemeen het goed recht der accountancy te bepleiten, en eindelijk eens eene grondige gedachtenwisseling uit te lokken over een onderwerp van groot gewicht, waarbij publieke en bijzondere belangen van duizenden zijn betrokken [.......]

De oprichters van het NIVA, C. Knapper Kzn, E. J. Korthals Altes, E. W. Schallenberg,

C. J. Theunisse en J. G. Ch. Volmer wilden drie dingen snel bereiken:

-de verbetering van de bedrifsuitoefening. Deze diende zo snel mogelijk op het Engelse niveau te komen;

-de beperking van toelating van alleen bonafide experts-boekhouders:

-de tnstelling van een eigen examen om in de toekomst mensen te kriggen die bekwaam waren (De Vries, 1985).

Het Nederlandsche Instituut van Accountants stelde hoge elsen aan haar leden. Wilde men lid worden van de vereniging dan kon men lid eerste klasse of lid tweede klasse worden. Eerste-klasseleden moesten tenminste vijf jaar als accountant hebben gewerkt of het NIVA-examen voor 1900 afgelegd hebben én gedurende vijf jaar als accountant werkzaam zijn geweest. Tot de tweede klasse werden alleen leden toegelaten die het diploma van het. NIVA hadden en tenminste 25 jaar oud waren. Tweede klasse-leden die gedurende viff jaren het beroep hadden ultgeoefend konden daarna lid van de eerste klasse worden.

In een rapport van het NIVA in 1895 werd beschreven wat de taak van een accountant zoal inhield:

- het inrichten van boekhoudingen

- het bijwerken en verbeteren van gebrekkige administraties

- het opmaken van balansen, winst- en liquidatierekeningen

- het assisteren van de curator bij faillissementen

- het controleren van rekeningen, boeken en balansen

(De Vries, 1985, p. 59).

Net als bilj de taakomschrijving in de brochure van Confidentia in 1889 stond de inrichting van de boekhouding op de eerste plaats en kwam de 
controle van de boekhouding als laatste taak. Dit laatste stond in contrast met de aandacht die door het publiek aan de controletaak werd geschonken. In 1896 bijvoorbeeld schreef J. D. Reiman het boek 'De accountant als controleur' waarin de controle van de administratie van naamloze vennootschappen als meest belangrijke taak van de accountant werd gezien. Rond 1900 ging de controletaak, mede door de vele fraudezaken, een steeds grotere rol spelen.

\section{Opleidingsmogelijkheden}

Er kwam steeds meer werk en al snel werden assistenten een noodzaak. Assistent kon men worden als men in het bezit was van een door het NIVA bestuur gewaarborgd boekhouddiploma. Assistenten mochten deelnemen aan cursussen van het NIVA maar mochten zich geen accountant noemen, omdat zij volgens het NIVA niet in het bezit waren van volwaardige deskundigheid en daardoor geen accountantsverantwoordelijkheid konden dragen (De Bruyne, 1980).

Met de groeil van toekomstige accountants kwamen er concurrenten van het NIVA op de markt. De belangrijkste waren: de Nederlandsche Bond van Accountants (de Bond) in 1899, de Nederlandsche Organisatie van Accountants (de Organisatie) in 1903, de Nederlandsche AccountantsVereeniging (NAV) die van 1906 tot 1919 tijdelijk was afgesplitst van het NIVA na een strijd onder andere veroorzaakt door Limperg en de in 1927 opgerichte Vereniging van Academisch Gevormde Accountants (VAGA).

In eerste instantie hadden het NIVA, de NAV, de Bond en de Organisatie hun eigen opleidingen en examens. Daarnaast waren er allerlei kleine organisaties actief die eveneens een eigen accountancyopleiding verzorgden. Deze variatie aan onderwijsprogramma's en examens waren er voor een belangrijk deel de oorzaak van dat de wettelijke erkenning van het accountancyberoep gedurende lange tijd uitbleef. De enige oplossing om tot wettelijke erkenning te komen was het. samenvoegen van opleidingen en examens. De wens om in ieder geval een eenvormig accountancy-examen te hebben leidde tot de fusie van de NAV en het NIVA in 1919. Een aantal jaren later, in 1927, fuseerde de Nederlandsche Organisatie van Accountants met het NIVA. Pas in 1927 was men het eens over het af te nemen examen en werd het eerste gemeenschappelijke examen afgenomen. De Nederlandsche Bond van Accountants 
fuseerde uiteindelijk in 1934 met het NIVA (De Bruyne, 1980; De Vries, 1985). De personen die betrokken waren geweest bij de oprichting van het NIVA, de NAV, de Bond en de Organisatie onderhielden eveneens contacten met Hogescholen. In 1915 resulteerde dat in de eerste academische accountancy-opleiding te Rotterdam waarbij personen als N. J. Polak, J. G. Ch. Volmer, R. A. Dijker en C. A. Blazer een grote rol speelden. In 1929 werd door Limperg in Amsterdam aan de universiteit bij de Faculteit der Handelswetenschappen een accountancy-opleiding gestart. Daarna volgde Tilburg met een academische accountancy-opleiding aan de Rooms Katholieke Handelshogeschool in 1931.

Ondanks het feit dat belangrijke personen van het NIVA, de Bond en de Organisatie in eerste instantie betrokken waren bij het opzetten van de universitaire opleidingen hadden zij toch moeite met de universitaire ontwikkelingen. Er werd dan ook besloten dat academicl geen lid van deze organisaties konden worden. Het resultaat was een Vereniging voor Academisch Geschoolde Accountants (VAGA) in 1927. Pas in 1932 werd het voor academisch opgeleide accountants mogelijk lid te worden van het. NIVA. Eind 1939 waren er van de in totaal 1983 NIVA leden slechts 35 in het bezit van een diploma van een van de Hogescholen.

Uiteraard moesten de normen van het universiteitsexamen wel voldoen aan de normen van het NIVA. Immers dit zou uit het vakoogpunt een goede norm moeten zijn. Of dat nu door een extra examen moest worden behaald of door praktijkervaring was nog niet duidelijk (De Vries, 1985). Een twistpunt tussen betrokken personen van het NIVA en de universiteiten was vooral het potentiēle gemis aan praktijkkennis bij de universitair opgeleide accountants en het mogelijke tekort aan theoretische kennis bij de NIVAaccountants (De Vries, 1985). Om het NIVA tegemoet te komen lieten de universiteiten in 1928 twee NIVA-accountants toe in de examencommissie van de untversitaire opleidingen. Deze zouden erop toe kunnen zlen of het examen voldoende vragen bevatte die betrekking hadden op de praktijk.

\section{Van NIVA naar NTVRA}

In 1930 kwam een wetswoorstel van de commissie-Bijleveld om een vereniging op te richten waaraan de leden van de Bond, de Organisatie, het NIVA en de VAGA zouden mogen deelnemen als zij een academisch examen 
hadden afgelegd of het examen van het nieuwe instituut zouden afleggen. De naam van de nieuwe vereniging zou Nederlands Instituut van Registeraccountants (NIVRA) zijn en haar taak zou bestaan uit het bijhouden van een speciaal accountantsregister van alle ingeschrevenen. Leden van minder belangrijke accountantsverenigingen moesten aan bepaalde voorwaarden voldoen. Zij dienden bijvoorbeeld veertig jaar of ouder te zijn en moesten minstens tien jaar praktijkervaring hebben. Vanwege deze extra voorwaarden hadden de accountants die geen lid waren van de Bond. de Organisatie, het NIVA of de VAGA vele bezwaren tegen deze plannen (De Vries, 1985). Door deze strijd bleek de wet politiek niet haalbaar en werd de indiening ervan voorlopig uitgesteld.

Met de aanvaarding van de Wet op de Registeraccountants (WRA) in 1962 was de wettelijke erkenning een feit en werd de accountancy als een professioneel beroep gezien (De Bruyne, 1980: De Hen, Berendsen \& Schoonderbeek, 1995). Nu zou wettelijk bepaald kunnen worden wie tot de Orde van Registeraccountants behoorden, hoe er gehandeld diende te worden in geval van slechte kwaliteit en wat de vorm en inhoud van het uniforme examen zou moeten zijn. In 1967 werd het Register van accountants ingesteld waarin alle leden van het NIVA en de VAGA werden ingeschreven. De opleidingen werden dus eindelijk als gelijkwaardig erkend (NIVRA, 1990).

Met de WRA werd het NIVA omgezet in NIVRA. Het NIVRA nam de opleiding van het NIVA over, de eindverantwoordelijkheid voor de inhoud van de opleiding en de examens lag nu echter bij de Minister van Onderwijs. Het examen werd uniform, en was nu niet alleen toegankelijk voor ingeschreven leden maar voor iedereen die belangstelling had (De Bruyne, 1980).

\section{Huidige taken}

Tegenwoordig is controle van de jaarrekening één van de hoofdtaken van accountants. Zoals eerder beschreven heeft de scheiding van eigendom en beheer het noodzakelijk gemaakt dat er een extern onafhankelijk persoon aangesteld werd om te controleren of de financiēle gegevens wel overeenstemmen met de werkelijke financiêle situatie van het bedrijf. Dit om belanghebbenden van het bedriff, zoals aandeelhouders, banken, beleggers, leveranciers, overheid en werknemers een betrouwbaar beeld te geven van de gang van zaken binnen het bedrijf. 
Een voorbeeld ter verduidelijking: als een bank door een bedrijf gevraagd wordt om een lening van fl. 500.000 te verstrekken, dan zal de bank financiēle gegevens van dat bedrijf willen hebben om te kunnen inschatten of dat bedrijf ook daadwerkelijk in staat zal zijn om die lening over een aantal jaren terug te betalen. Als het bedrijf geen accountantscontrole heeft, dan zal de bank de financiële gegevens op basis van goed vertrouwen en eigen onderzoek moeten geloven. Aangezien het bedrijf er belang bij heeft om de lening te verkrijgen bestaat er echter een kans dat het bedrijf de cijfers mooier makt dan dat ze in werkelijkheid zijn om zo de bank te overtuigen dat het bedrijf goed functioneert. Als er wel een accountant bij betrokken is, mag verwacht worden dat deze externe en onafhankelijke accountant de gegevens al gecontroleerd heeft op eventuele fouten en onregelmatigheden. Met behulp van de accountant is er dus een grotere kans dat de belanghebbenden een betrouwbaar beeld krijgen van hoe het bedrijf werkelijk draait.

Bij een algemene controle van de jaarrekening gaat de accountant na of de informatie die in de jaarrekening, het jaarverslag en de overige gegevens staat, overeenkomt met het werkelijke vermogen en resultaat van dat boekjaar (NIVRA, 1990). Daarbij onderzoekt de accountant of de transacties en andere ondernemingsactiviteiten juist en volledig zijn verwerkt. Als de jaarrekening en de andere gegevens een betrouwbaar, toereikend en aanvaardbaar beeld geven, dan zal een verklaring afgegeven worden waarin staat dat de jaarrekening goed is bevonden.

Een aanvullende controletaak van accountants is de controle bij fusies of overnames van bedrijven of bij het vaststellen van de waarde van aandelen bij vennootschappen. Ook bij deze controles gaat het er voornamelijk om vast te kunnen stellen of de opgegeven financiële situatie van het bedrijf overeenkomt met wat het bedrijf in werkelijkheid bezit. Hieruit zal echter geen verklaring voortvloeien, maar een advies naar de opdrachtgever.

Een laatste belangrijke taak die accountants kunnen vervullen is adviezen geven op het terrein van de optimalisering van de informatievoorziening, de organisatiestructuur, computerhandelingen en productiemethodes (Arens \& Loebbecke, 1994).

In dit proefschrift zal de algemene controle van de jaarrekening centraal staan. Dit houdt in dat de controle bij fusies en overnames en het verlenen van adviezen buiten beschouwing zijn gelaten. 


\section{Controle van de Jaarrekening}

Een accountant die als taak heeft de jaarrekening van een bedrijf te controleren zal over het algemeen minstens drie keer per jaar dat bedrijf bezoeken. De eerste keer zal dat zijn vanwege de controleplanning die wordt gemaakt. Daarin worden voorbereidingen getroffen voor de daadwerkelijke controle. Tijdens de vervolgfase van deze werkelijke controle, die de interimcontrole wordt genoemd, is het de tweede maal dat de accountant bij het bedrijf zal komen. Daarna zal de controle afgerond moeten worden en zal de accountant het bedrijf wederom bezoeken. Daarnaast zal het vaak gebeuren dat een accountant om nadere informatie te verkrijgen het bedrijf tussentijds zal bezoeken. Hoe het verloop van zo'n controleproces eruit ziet wordt in Figuur 1.1 weergegeven.

In de planningsfase zullen accountant en opdrachtgever, voordat begonnen wordt met de bedrijfsverkenning, overeenstemming moeten bereiken over de inhoud van de controle-opdracht (NIVRA, 1990). Verder zal er gesproken worden over andere vormen van dienstverlening zoals advisering over informatievoorziening. productiemethodes, etc. Ook de wijze waarop gerapporteerd gaat worden zal aan de orde komen.

Na de formele afspraken voorafgaand aan de opdrachtaanvaarding zal de accountant meer over het bedrijf te weten moeten komen om in te kunnen schatten welke risico's hij loopt bij de controle van een bedrijf. De hoogte van de risico's bepalen de hoeveelheid tijd en geld die er in de controle wordt gestoken (Arens \& Loebbecke, 1994) ${ }^{1}$.

Om deze risico's in te kunnen schatten zal de accountant bijvoorbeeld nagaan wat de wettelijke structuur van het bedrijf is: is het een N.V., B.V. of firma en wat de wettelijke voorschriften voor het bedrijf zijn. Eveneens is het belangrijk om te achterhalen waar het bedrijf in- en verkoopt. Als het bijvoorbeeld een Oost-Europees land is met sterk schommelende valutawaarden, dan is er waarschijnlijk meer kans op onvolkomenheden in de jaarrekening, dan als het een land met een zeer stabiele munteenheid betreft. Ook is het essentieel te weten of er nog meer vestigingen zijn van het bedrijf. Als er meerdere vestigingen zijn waarvan de accountant niet op de hoogte is, dan is het mogelijk dat daar een voorraad goederen ligt die niet is opgenomen in de balans. Tevens zal de accountant moeten weten of er

\footnotetext{
${ }^{1}$ De verschillende soorten risico's: het inherente risico, het interne controle risico en het ontdekkingsrisico die voor het risicomodel van belang zijn (zie Arens \& Loebbecke, 1994), worden hier niet uitgewerkt aangezien het risicomodel in dit proefschrift verder niet aan de orde komt.
} 
sprake is van veel concurrentie en hoe het bedrijf zich daarin kan handhaven. Meestal kan deze bedrijfsinformatie worden verkregen door enerzijds gesprekken met het management te voeren en door anderzijds eventuele vestigingsplaatsen te bezoeken en informatie over de branche te lezen.

Wat betreft de financièle stand van zaken is het belangrijk te weten hoe de financiële cijfers van het betreffende jaar zich verhouden tot eerdere jaren en hoe diverse înanciële gegevens van eenzelfde jaar zich onderling verhouden. Essentiële vragen die gesteld kunnen worden zijn bijvoorbeeid: hoe verhoudt de omzet zich tot andere jaren, wat is de trend van de hoogte van de voomaden en hoe ontwikkelt de brutowinstmarge zich in de loop der jaren. Daarnaast zljn bepaalde verhoudingen tussen kengetallen belangrijk, zoals de Solvabiliteitsratio: totale activa ten opzichte van totale schulden en de Liquiditeitsratio: de relatie tussen liquide middelen, kortlopende vorderingen en te betalen verplichtingen op korte termijn. Het is ook mogelijk dat de accountant gegevens van soortgelljke bedrijven erbij betrekt om daar de gecontroleerde onderneming mee te vergelijken (NIVRA, 1990).

Bij de volgende stap zal de accountant gaan inventariseren op welke wijze het bedrijf de administratieve organisatie geregeld heeft en welke controleprocedures het bedrijf hier intern op uitoefent. Zijn de administratieve organisatie en de interne controle goed uitgevoerd, dan kan men er tot op zekere hoogte vanuit gaan dat er relatief weinig fouten en onregelmatigheden in de jaarrekening zitten en dat het interne controle risico laag is. Op welke wijze kan nu in zo'n eerste fase worden bepaald of de administratieve organisatie goed in elkaar zit? Een van de belangrijkste kenmerken van een goed georganiseercle administratieve organisatie is het bestaan van functiescheidingen. Functiescheiding wil zeggen, dat er sprake is van een scheiding tussen de functies waarin de handelingen: beschikken, bewaren, registreren en controleren voorkomen. Dit betekent dat er niet één persoon verantwoordelijk is voor bijvoorbeeld bewaren en registreren, maar dat er één persoon verantwoordelijk is voor bewaren en ến voor registreren. Stel, iemand fungeert in een bedrijf als magazijnmeester. Tevens houdt hij de registratie bij van welke goederen er in en uit het magazijn gaan. Er is in dit bedrijf dus geen functiescheiding tussen bewaren en registreren. Het is goed mogelijk dat die persoon goederen meeneemt en daarin gaat handelen zonder dat andere personen er weet van hebben. Een betere functiescheiding zou hier zijn geweest als iemand anders de registratie bijhoudt van wat er in en uit het magazijn gaat. Voor de accountant is functiescheiding van essentieel 
belang om het risico op fraude te kunnen beoordelen en eventueel te kunnen verkleinen.

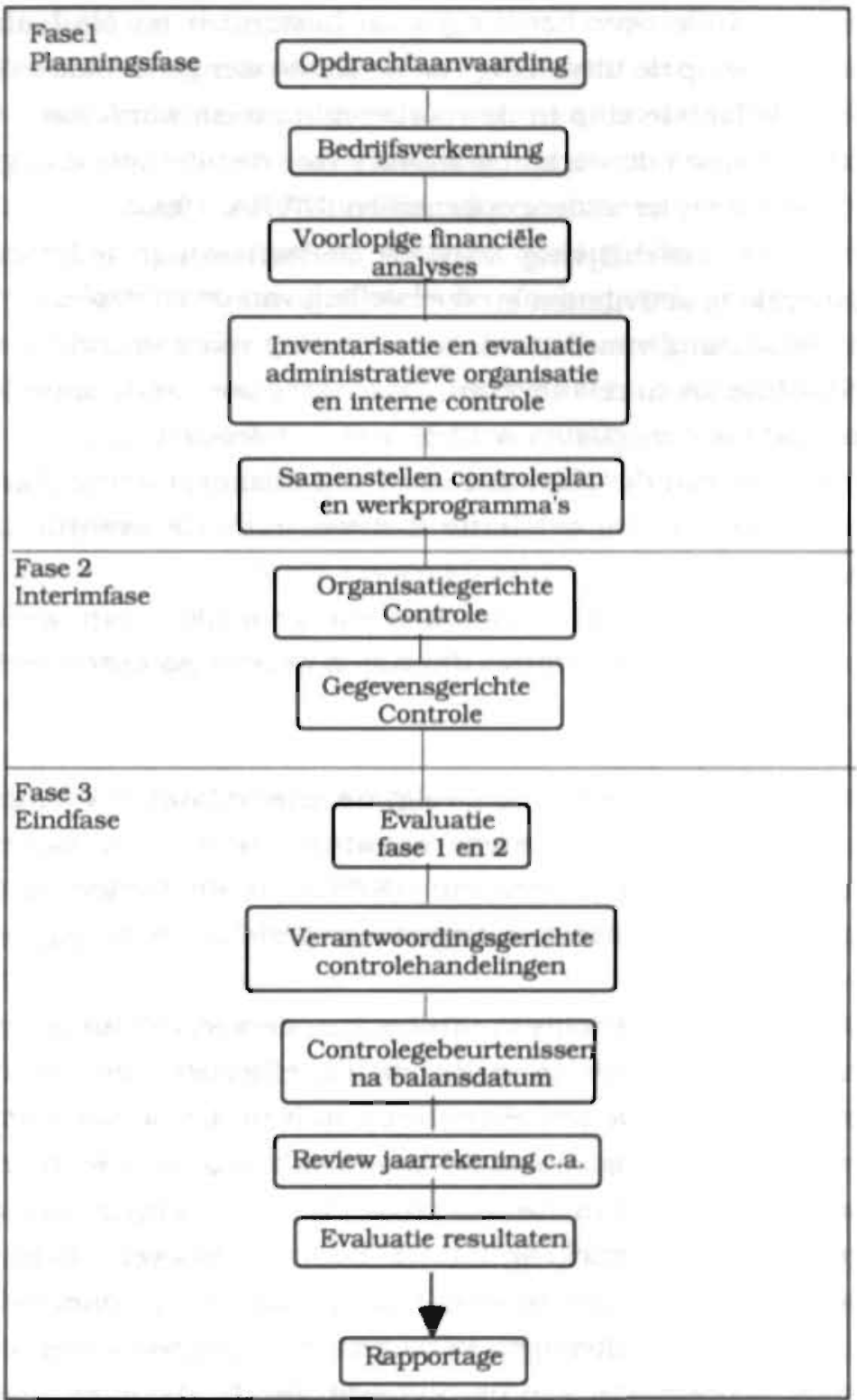

Figuur 1.1 Het verloop van het controleproces Uit: NIVRA (1990); Arens en Loebbecke (1994) 
Voor een accountant is het essentieel als het management van een bedrijf de volgende zaken goed heeft geregeld (Arens \& Loebbecke, 1994): a) functiescheiding, b) een heldere autorisatie van transacties en activiteiten, c) het correct opslaan van documenten en bestanden, d) het bestaan van fysieke controle over bezittingen en bestanden en als laatste, e) een continue controle op de uitvoering van de eerste vier genoemde zaken.

Tijdens de laatste stap in de voorbereidingsfase wordt het controleplan ultgewerkt en worden de werkprogramma's voor de interimfase opgesteld.

Hierin wordt onder andere opgenomen (NIVRA, 1990):

-een korte beschrijving van de onderneming. indicatie van de belangrijkste activiteiten en doelstelling van de controle:

-een opsomming van de in de jaarrekening voorkomende posten, zowel In absolute als in relatieve zin. Daarnaast worden de specifieke risico's genoemd die deze posten wellicht zullen opleveren:

-hoofdlijnen van de administratieve organisatie/interne controle en de uitkomsten van de evaluatie daarvan plus de eventueel te nemen maatregelen;

* controlemiddelen en technieken die gebrulkt gaan worden en de aspecten van de procedures die zullen worden gecontroleerd tijdens de interimcontrole.

Na deze eerste planningsfase volgt de interimfase. In de interimfase is het doel tot een meer precleze schatting te komen van fouten en onregelmatigheden in de jaarrekening (NIVRA, 1990). In deze fase vinden er twee soorten controles plaats: de organisatiegerichte en de gegevensgerichte controles.

Bij de organisatiegerichte controles kan de accountant gebruik maken van controlemiddelen als proceduretests, cifferbeoordelingen en waarnemingen ter plaatse. De proceduretest houdt in dat de accountant nagaat of de interne controle procedures daadwerkelijk nageleefd worden. Hij zal dit onder andere doen door te controleren of bevoegde personen hun handtekening of paraaf onder relevante stukken hebben gezet. Cijferbeoordelingen worden in deze fase gedaan om te onderzoeken of er wellicht bepaalde ontwikkelingen in de financiäle gegevens aanwezig zijn die afwijken van de norm. Het kan bijvoorbeeld zijn dat de omzet in vergelijking met de voorgaande jaren aanzienlijk is gedaald. De accountant zal dan moeten achterhalen wat de oorzaak daarvan is. Waarnemingen ter plaatse 
wil zeggen dat de accountant in het bedrijf observeert of de intern afgesproken procedures werkelijk worden nageleefd. Als er bijvoorbeeld verschillende entreeprijzen zijn voor een museum, $65^{+}$-kortingen en dergelijke, dan kan de accountant door bij de ingang te gaan staan controleren of de juiste kortingen inderdaad aan de juiste personen worden gegeven.

Gegevensgerichte controles worden uitgevoerd om vast te kunnen stellen of de waardenkringlopen geen fouten bevatten (NIVRA, 1990). Een waardenkringloop geeft aan hoe geldmiddelen en goederen de afdelingen in een bedrijfshuishouding doorlopen. Bijvoorbeeld, de waardenkringloop van een handelsonderneming bestaat uit waarden zoals goederen en geld die via de afdelingen inkopen en voorraden naar de afdeling verkopen gaan. Onder andere met behulp van deze waardenkringloop kan de accountant door verbandscontroles nagaan of datgene wat is ingekochit ook daadwerkelijk is ontvangen en betaald. Omgekeerd kan de accountant ook nagaan of datgene wat verkocht is ook is verzonden en of er geld voor is ontvangen. De accountant zal bij zulke verbandscontroles onderzoeken of de waarden op de juiste wijze zijn afgehandeld en verwerkt in de financiele administratie (NIVRA, 1990).

Deze tweede fase zal eindigen met een gedetallleerde planning voor de volgende en tevens laatste fase.

Fase drie is de afsluitende fase van het controleproces. Daarin wordt de controle afgerond en zal een verklaring worden afgegeven. Deze fase begint met een evaluatie van de uitkomsten van de eerste fase en de interimfase. In de evaluatie zal aandacht worden besteed aan de fouten die nog in de jaarrekening zouden kunnen zitten.

$\mathrm{Na}$ de evaluatie zullen er verantwoordingsgerichte controlehandelingen worden verricht, zoals de cijferbeoordeling en de controle van opvallende posten. De cijferbeoordelingen in deze fase komen overeen met de cijferbeoordelingen die in de eerste en tweede fase zijn genoemd. Alleen zijn ze hier specifieker gericht op posten van de jaarrekening. Bij de controle van opvallende posten worden transacties nagetrokken die op bepaalde rekeningen betrekking hebben. Dat zijn bijvoorbeeld bijzondere transacties met gelieerde ondernemingen of transacties waarin de bedrijfsleiding een bijzondere rol heeft gespeeld. Als het nodig is zullen er eveneens aanvullende controles uitgevoerd worden. Dit zijn bijvoorbeeld, het opvragen van 
bankverklaringen, het bijwonen van inventarisaties of het verrichten van kadastrale recherche (NIVRA, 1990).

Aangezien de jaarrekening per definitie later wordt opgesteld dan de balansdatum kunnen er in de tussenliggende periode lenkele weken tot maanden) nog belangrijke dingen zijn gebeurd. Deze gebeurtenissen zullen als ze informatie geven over de situatie per balansdatum betrokken moeten worden in de jaarrekening. Ook zal nagekeken worden of de jaarrekening, het jaarverslag en andere gegevens conform de wettelijke eisen zijn opgesteld. Verder zal de accountant nagaan of alle controles zijn uitgevoerd en of die allemaal in het dossier zijn vastgelegd. Hierna zal nogmaals worden bekeken of de tolerantie en risico's binnen de aanvaardbare marges zijn gebleven.

Het controleproces zal eindigen met een accountantsverklaring die goedkeurend, met beperking, oordeelonthoudend of afkeurend kan zijn. De Raad van Commissarissen en de directie krijgen een accountantsrapport waarin de resultaten van de controle worden beschreven en krijgen desgewenst aansluitend een mondelinge toelichting door de verantwoordelijke accountant.

\section{Het accountantsteam}

Tot nu toe is steeds gesproken van de accountant, alsof deze als Individu de gehele controle op zich neemt. Dat geldt in leder geval niet voor (middel)grote accountantskantoren waar accountants voornamelijk in teams werken. Over het algemeen bestaat zo'n team uit de volgende personen: een verinoot (partner), een medewerker (manager), een controleleider (senioi) en een aantal assistenten (junior). De vennoot is hiërarchisch gezien de hoogste persoon op een accountantskantoor. Hij zorgt met name voor nieuwe cliênten en voor adequate dienstverlening aan bestaande cliênten. Hij voert dan ook de intake-gesprekken met nieuwe cliënten en doet de uiteindelijke rapportage van de controle in het bijzijn van de medewerker. Tevens heeft de vennoot de supervisie oiver het gehele team en heeft hij de eindverantwoordelijkheid voor een opdracht. Na de vennoot komt de medewerker die verantwoordelijk is voor het werk van controleleiders en assistenten. Hij moet ervoor zorgen dat de controleleider en de assistenten voldoende instructies krijgen over de algemene opzet van de controle en wat 
er uiteindelijk moet worden bereikt. Medewerkers kijken de working papers ${ }^{2}$ na en geven vervolgopdrachten aan de controleleiders. De controleleider is de accountant die de verantwoordelijkheid draagt voor de daadwerkelijke uitvoering. Hij geeft specifieke uitleg en instructies aan de assistenten en controleert de wijze waarop de assistenten de taken uitvoeren. Hij staat daarbij onder supervisie van de medewerker (NIVRA, 1990).

\section{Opleidingen tot Reglsteraccountant}

Er zijn tegenwoordig drie opleidingstrajecten die een programma bieden waarmee het diploma van Registeraccountant behaald kan worden. Dat zijn de deeltijdopleiding bij de NIVRA-Nijenrode universiteit en een combinatie van full-time doctorale opleiding en deeltijd postdoctorale opleiding bij reguliere universiteiten. Daarnaast verzorgen de HEAO's een deel van de opleiding tot Registeraccountant. Deze HEAO opleiding dient vervolgd te worden door de deeltijdopleiding aan het NIVRA=Nijenrode of het doctorale accountancyprogramma aan de reguliere universiteiten.

Achtereenvolgens worden hieronder de HEAO-accountancy-opleiding, de NIVRA-Nijenrode opleiding en de 'reguliere' universitaire opleiding kort besproken.

\section{HEAO-deelopleiding ${ }^{3}$}

De vierjarige accountancy-opleiding aan de HEAO begint in het propaedeusejaar met inleidende economievakken. (In Tabel 1.1 wordt een overzicht van een HEAO-accountancyprogramma gegeven), Vakken als Algemene Economie, Bedrijfseconomie, Commerclële Economie, Boekhouden en Bedrijfsorganisatle vormen de kern in de propaedeuse. Daarnaast worden in de propaedeuse vakken gegeven zoals Recht, Informatiekunde, Statistiek, Wiskunde, Psychologie, Zakelijke Communicatie en Lichamelijke Opvoeding.

\footnotetext{
${ }^{2}$ Working papers bevatten de schriftelijke of electronische vastlegging van de controlewerkzaamheden, inclusief de lijsten waarop aantekeningen zijn gemaakt betreffende interne controleprocedures en posten die niet goed zijn bevonden bij een bedrijf.

${ }^{3}$ De opleidingsgegevens die hier worden gepresenteerd zijn afkomstig van de HEAO van de Hogeschool 'Windesheim' te Zwolle. De meeste accountancy programma die de HEAQ's aanbieden verschillen weinig qua accountancy vakken. Deze HEAO is als voorbeeld genomen om een globaal beeld te geven van de accountancy vakken die HEAO studenten dienen te volgen om Registeraccountant te kunnen worden.
} 
Vanaf het tweede studiejaar kunnen de studenten kiezen voor de accountantsrichting. In dit accountancytraject beginnen de studenten met een introductiecasus waarin het accountantsberoep en de accountantsstudie aan de orde zullen komen. De belangrijkste vakken die in het tweede jaar aan de orde komen zijn: Algemene Economie, Bedrijfscalculatie, Administratieve Organisatie, Bedrijfsadministratie, Wiskunde, Inleiding Bestuurlijke Informatlevoorziening. Statistiek, Belastingrecht, Financiering en Interne Berichtgeving. Het vak Bedriffscalculatie behandelt de technieken op het gebled van financièle rekenkunde. In het vak Administratieve Organisatie wordt studenten geleerd hoe organisatorische maatregelen van invloed kunnen zijn op de financlële administratie. Het vak Inleiding Bestuurlijke Informatievoorziening behandelt de elementaire beginselen van de Administratieve Organisatie in combinatie met gegevensverwerking met behulp van de computer. Bij Financiering worden de verschillende mogelijkheden ten aanzien van de financieringsstructuur van een onderneming behandeld. In het vak Kosten en Opbrengsten (komt overeen met Management Accounting) krijgen studenten te maken met de invloed van financièle informatie op de interne organisatie zelf.

Naast deze hoofdvakken wordt een aantal aanvullende vakken gegeven om studenten meer algemene kennis te verschaffen. Deze vakken zijn: Zakelijke Communicatte, Sociale Vaardigheidstraining en Engels.

Een belangrijk vak in het derde studiejaar is het vak Elementaire Kennis der Accountantscontrole waarin het doel van de controle, controlebegrippen en de controle aanpak centraal staan. Verder wordt doorgegaan op Bedrijfsadministratie, Belastingrecht en Administratleve Organisatie (AO). Ook wordt het vak Financial Accounting oftewel Externe Berichtgeving in dit derde studiejaar gegeven. In dit vak wordt ingegaan op de manier waarop financiële informatie aan extern geïnteresseerden gepresenteerd kan worden. Het derde studilejaar wordt afgesloten met een stage van twee tot vijf maanden bif een accountantskantoor. Het doel van de stage is dat de studenten de opgedane theorie in praktijk kunnen brengen en dat de studenten een goed beeld krijgen van het accountantsberoep.

In het viercle en tevens laatste studiejaar vervolgen studenten de belangrijkste accountancyvakken: Elementaire Kennis der Accountantscontrole en Bestuurlijke Informatievoorziening. Nieuwe vakken in het vierde studrejaar zijn: Bedrijfsorganisatie en Management en Organisatie. Het 
accountantsprogramma wordt afgesloten met een afstudeerscriptie waarin zowel praktijk als theorie aan de orde dienen te komen.

Tabel 1.1 Studieprogramma Accountancy-opleiding HEAO (Studiegids HEAO Windesheim Zwolle 1994/1995)

\begin{tabular}{|c|}
\hline Eerste studiejaar (Propaedeuse) \\
\hline $\begin{array}{l}\text { Algemene Economie } \\
\text { Bedrijfseconomie } \\
\text { Commerclale economie } \\
\text { Recht } \\
\text { Informatiekunde } \\
\text { Engels } \\
\text { Zakelijke Communicatie } \\
\text { Bedrijfsorganisatie } \\
\text { Statistiek } \\
\text { Psychologie } \\
\text { Ethiek } \\
\text { Administratief Comptabele Informatie } \\
\text { Wiskunde } \\
\text { Lichamelijke Opvoeding } \\
\end{array}$ \\
\hline Tweede studiejaar \\
\hline $\begin{array}{l}\text { Introductiecasus } \\
\text { Administratieve Organisatie } \\
\text { Kosten \& Opbrengsten (Management Accounting) } \\
\text { Financiering } \\
\text { Belastingrecht } \\
\text { Algemene Economie } \\
\text { Bedrijfscalculatie } \\
\text { Bedrijfsadministratie } \\
\text { Wiskunde } \\
\text { Inleiding Bestuurlijke Informatievoorziening } \\
\text { Statistiek } \\
\text { Zakelijke Communicatie } \\
\text { Sociale Vaardigheidstraining } \\
\text { Engels }\end{array}$ \\
\hline Derde studiejaar \\
\hline $\begin{array}{l}\text { Elementaire Kennis der Accountantscontrole } \\
\text { Administratieve Organisatie } \\
\text { Externe Berichtgeving } \\
\text { Belastingrecht } \\
\text { Bedrijfsadministratie } \\
\text { Privaatrecht } \\
\text { Sociale Vaardigheidstraining } \\
\text { Lichamelijke Opvoeding } \\
\text { Stage }\end{array}$ \\
\hline Vierde studiejaar \\
\hline $\begin{array}{l}\text { Elementaire Kennis der Accountantscontrole } \\
\text { Externe Berichtgeving } \\
\text { Belastingrecht } \\
\text { Bestuurlifke Informatievoorziening } \\
\text { Bedrijfsorganisatie } \\
\text { Zakelijke Communicatie } \\
\text { Ethiek } \\
\text { Afstudeerscriptie }\end{array}$ \\
\hline
\end{tabular}


NIVRA-deeltijdopleiding

Vanaf september 1994 is de NIVRA-opleiding gedeeltelijk met de universiteit. Nijenrode samengegaan wat voor de studenten tot gevolg heeft dat ze zowel een doctorandustitel in Informatiemanagement als een Registeraccountantstitel kunnen behalen.

De NIVRA-opleiding is een 7,5-jarige deeltijdopleiding van gemiddeld één dag in de week. Een NIVRA-student die na het VWO met de opleiding begint werkt over het algemeen als derde assistent bij een accountantskantoor. $\mathrm{Na}$ een aantal jaren werkervaring zal de NIVRA-student opklimmen van derde assistent via tweede naar eerste assistent en voordat hij de NIVRA-opleiding heeft afgerond is hij over het algemeen al controleleider.

De NIVRA-opleiding begint net als het tweede jaar van de HEAO met een introductiecasus over wat de student de komende acht jaar te wachten zal staan. Daarna begint het eerste studiejaar met de inleidende vakken: Inleidıng Bedrijfseconomie, Inleiding Bestuurlijke Informatievoorziening, Boekhouden en Recht 1/ Belastingrecht 1 (Zle Tabel 1.2 voor een overzicht). Deze inleidende cursussen hebben onder andere als doel de studenten vertrouwd te maken met het begrippenkader van de bedrijfseconomie en de accountancy. Verder trachten de opleiders met vakken als Boekhouden, Belastingrecht en Inleiding in de Bestuurliyke Informatlevoorzlening ondersteuning te bieden bij de problemen dile de NIVRA-student als assistent in de praktijk zal tegenkomen.

Tijdens het tweede studiejaar krijgen studenten de vakken: Controlebeginselen 1. Financièle Rekenkunde. Bedrijfsadministratie en Statistiek. Controlebeginselen 1 is een praktijkgerichte cursus waarbij het controleproces centraal staat. Daarnaast wordt in deze cursus aandacht besteed aan de mogelijke controletechnieken en controlemiddelen. Bij het vak Financiēle Rekenkunde leren studenten actuariêle grootheden als interest, rente en lijfrente te berekenen. De cursus Bedrijfsadministratie behandelt onder andere waardering van deelnemingen, fusies, consolidatie, fiscale faarrekening en wettelijke reserves. Bij Statistiek wordt getracht studenten praktische vaardigheden bij te brengen op het gebied van statistische methoden en technieken.

In het derde studiejaar worden voornamelijk aanvullende vakken gegeven zoals Kosten en Opbrengsten, Algemene Economie, Management \& Organisatie en Recht 2. Het vak Kosten en Opbrengsten heeft als doel duidelijk te maken hoe informatie over kosten en opbrengsten gebruikt kan 
worden om de beheersing van de organisatie te ondersteunen. In de cursus Algemene Economie wordt studenten geleerd om een verband te leggen tussen algemene economische factoren zoals inflatie, wisselkoersen en de effecten daarvan op de accountantspraktijk. Bij de cursus Management \& Organisatie wordt geprobeerd de studenten inzicht te geven in het functioneren van organisaties en de middelen waarmee dat beoordeeld kan worden. Tijdens het vak Recht 2 wordt ingegaan op de juridische onderwerpen waarmee een accountant in aanraking kan komen bij het uitvoeren van zijn beroep. Met name ondernemingsrecht en vermogensrecht komen in deze cursus aan de orde.

In het vierde studiejaar krijgen de studenten de vakken Financiering. Bestuurlijke Informatievoorziening, Management Accounting en Belastingrecht 2. Het vak Financiering behandelt in grote lijnen de operationele kasstromen, de financièle kasstromen, de financiēle structuur en het financiēle management van activa. Bij Bestuurlijke Informatievoorziening is het doel dat studenten aan het einde van de cursus in staat zullen zijn om de informatievoorziening van huishoudingen te kunnen beoordelen. Management Accounting (Interne Berichtgeving) handelt over budgettering en kostprijsbepaling. In Belastingrecht 2 worden de fiscale aspecten zoals vennootschapsbelasting en winstbepalingen van verschillende typen ondernemingen behandeld.

In het vijfde studiejaar worden de cursussen. Financial Accounting. Controlebeginselen 2, Externe Verslaggeving en Methodologie gegeven. Het vak Financial Accounting (Externe Berichtgeving) houdt in dat er aandacht wordt besteed aañ de eisen die gesteld kunnen worden aan de flnanciẹle informatie. Controlebeginselen 2 sluit nauw aan op Controlebeginselen 1 maar gaat dieper in op het controleproces. Bij Externe Verslaggeving wordt studenten geleerd aan welke maatschappelijke regels de jaarrekening en andere vormen van verslaggeving moeten voldoen.

In de laatste studiejaren staan met name Administratieve Organisatie en Leer van de Accountantscontrole centraal. De cursisten moeten na het volgen van de cursus Administratieve Organisatie in staat zijn een administratieve organisatie op te zetten en te beoordelen, adviezen kunnen geven om de Administratieve Organisatie te optimaliseren en de output van informatiesystemen kunnen beoordelen op betrouwbaarheid, efficlëntie en effectiviteit. In het vak Leer van de Accountantscontrole wordt onder andere aandacht besteed aan functie, plaats en inhoud van de controle, wat de 
verantwoordelijkheid van de accountant bij de controle is en hoe de internationale samenwerkingsverbanden er momenteel uitzien. Deze cursus behandelt al datgene wat ligt tussen de aanvaarding van een opdracht tot en met de rapportage van de opdracht.

De afstudeeropdracht bestaat uit het schrijven van een scriptie waarvoor een literatuurstudie moet worden verricht en een onderzoek dient te worden uitgevoerd. De probleemstelling in de scriptie moet of in de praktijk voorkomen of op een theoretisch accountancy vakgebied zoals Externe Berichtgeving. Bestuurlijke Informatievoorziening of Accountantscontrole liggen.

Tabel 1.2 Studieprogramma NIVRA 1990 (Studiegids NIVRA-Nijenrode (1994/ 1995).

\begin{tabular}{|c|}
\hline $\begin{array}{c}\text { Fawe } \mathbf{1}^{\mathbf{4}} \\
\text { Eerste studiejaar }\end{array}$ \\
\hline $\begin{array}{l}\text { Introductiecasus } \\
\text { Inleiding Bedrijfseconomie } \\
\text { Boekhouden } \\
\text { Inlelding Bestuurlijke Informatievoorziening } \\
\text { Recht 1/Belastingrecht 1 }\end{array}$ \\
\hline $\begin{array}{l}\text { Tweede studieiaar } \\
\text { Financiele Rekenkunde/Levensverzekeringswiskunde } \\
\text { Controlebeginselen I } \\
\text { Bedrifsadministratie } \\
\text { Statistiek }\end{array}$ \\
\hline Derde studiejaar \\
\hline $\begin{array}{l}\text { Kosten \& Opbrengsten } \\
\text { Algemene Economie }\end{array}$ \\
\hline $\begin{array}{c}\text { Fase } \mathbf{2}^{\mathbf{5}} \\
\text { Derde studiejaar }\end{array}$ \\
\hline $\begin{array}{l}\text { Management \& Organisatie } \\
\text { Recht } 2\end{array}$ \\
\hline Vierde studiejaar \\
\hline $\begin{array}{l}\text { Financiering } \\
\text { Bestuurijjke Informatievoorziening } \\
\text { Belastingrecht } 2 \\
\text { Management Accounting }\end{array}$ \\
\hline Vijfde studiejaar \\
\hline $\begin{array}{l}\text { Financial Accounting } \\
\text { Controlebeginselen } 2\end{array}$ \\
\hline
\end{tabular}

\footnotetext{
4VwO'ers beginnen in deze eerste fase.

5 HEAO'ers die het accountantstraject op de HEAO hebben gevolgd kunnen via een aanpassingsprogramma instromen in de tweede of derde studiefase van het NIVRA/Nijenrodeprogramma.
} 
Vervolg Tabel 1.2

\begin{tabular}{|c|}
\hline $\begin{array}{c}\text { Fese } 3 \\
\text { Vijfde studiejaar }\end{array}$ \\
\hline $\begin{array}{l}\text { Externe Verslaggeving } \\
\text { Methodologie/Toegepast Onderzoek }\end{array}$ \\
\hline Zesde studiejaar \\
\hline $\begin{array}{l}\text { Externe Verslaggeving (vervolg) } \\
\text { Administratieve Organisatie } \\
\text { Bedrijfseconomie } \\
\text { Leer van de Accountantscontrole }\end{array}$ \\
\hline Zevende studiejaar \\
\hline $\begin{array}{l}\text { Administratieve Organisatie } \\
\text { Leer van de Accountantscontrole (vervolg) }\end{array}$ \\
\hline Achtste studiejaar \\
\hline Afstudeeropdracht \\
\hline
\end{tabular}

Accountancy-opleidingen aan de 'reguliere' Universiteiten 6

Bij de Rijksuniversiteit Limburg worden in het eerste studiejaar de inleidende vakken van de afstudeerrichtingen Algemene Economie en Bedrijfseconomie aangeboden. Verder dienen eerstejaars studenten een aantal essentiële practica als Statistiek, Wiskunde en Financiële Informatie Systemen (FIS) te volgen (Voor een overzicht van dit accountancytraject zie Tabel 1.3). Studenten die Registeraccountant willen worden zulien na het propaedeusejaar de afstudeerrichting Bedrijfseconomie moeten kiezen. Tijdens het tweede studiejaar dat ook wel het basisdoctoraal wordt genoemd zijn alle bedrijfseconomische disciplines vertegenwoordigd. Vakken als Marketing, Organisatie, Financiering en Berichigeving zijn verplicht. Daarnaast worden vakken als Wiskunde en Financiële Informatie Systemen verder uitgediept tijdens practica.

Na dit basisdoctoraal zal de student die Registeraccountant wil worden het specifieke Berichtgevingstraject moeten kiezen. De kernvakken die hierin een grote rol spelen zijn Voortgezette Financiēle Informatie Systemen, Interne en Externe Berichtgeving. Bestuurlijke Informatievoorziening en Administratieve Organisatie (BIV/AO), Fiscaal Recht en Auditing.

Voortgezette FIS gaat enerzijds over de boekhoudkundige aspecten van het samenstellen van een geconsolideerde jaarrekening en anderzijds over de

\footnotetext{
${ }^{6}$ De opleidingsgegevens die in deze paragraaf gepresenteerd worden zijn afkomstig van de Rijksuniversitelt Limburg (RL). Belangrijkste reden om de RL, te kiezen, is het feit dat de empirische onderzoeken ult Hoofdstuk 3,4 \& 5 daar zijn uitgevoerd.
} 
te volgen procedures voor het samenstellen van een fiscale jaarrekening op basis van een bedrijfsadministratie. In het vak Interne Berichtgeving (Management Accounting) worden methodes aangeleerd voor onder andere kostprijsbepaling, kostenallocatie en budgettering. De cursus Financiee! Management I behandelt de belangrijkste theorieên en concepten op het gebled van investeringen, waardering van ondernemingen, fusies, overnames en dergelijke. In het vak Externe Berichtgeving (Financial Accounting) wordt aandacht geschonken aan de mogelijke effecten van de berichtgeving van financiēle prestaties en de financiële stand van zaken van een onderneming op externe belanghebbenden. In de cursus BIV/AO-I worden studenten kennis en vaardigheden aangeleerd over de administratieve organisatie binnen ondernemingen. Bij het vak Financiële Rekenkunde en Levensverzekeringswiskunde leren studenten actuariēle grootheden als interest, netto jaarpremie en premiereserves te berekenen.

Naast de aangeboden cursussen worden er in het derde studiejaar vaardigheidstrainingen aangeboden als Administratieve Organisatie en Schematechnieken, Ontwerpen van een expertsysteem ten behoeve van een bedrijfsdiagnose en Het gebruik van de PC bij financieel economische beslissingscalculaties. De vaardigheidstraining Administratieve Organisatie en Schematechnieken is verplicht. Uit de andere twee vaardigheidstrainingen moeten de studenten één kiezen.

In het vierde studiejaar zullen Bestuurlijke Informatie Voorziening/ Administratieve Organisatie II (BIV/AO-II), Internationale Externe Berichtgeving, Management en Informatievoorziening, Ondernemingsrecht, Auditing. Fiscaal Recht I en II en Externe Berichtgeving II gevolgd moeten worden. De vaardigheidstraining Financięle Analyse en Cijferbeoordeling is verplicht. Daarnaast hebben studenten de keuze om vaardigheidstrainingen als Communicatieve Vaardigheden in Accountancy of Ontwerpen van Financiêle informatiesystemen te kiezen.

Bij het vak BIV/AO-II wordt de Inhoud van BIV/AO-I vervolgd. De cursus Internationale Externe Berichtgeving behandelt de gevolgen die het buitenlands opereren van ondernemingen met zich meebrengt voor het opstellen van de jaarrekening. Management en Informatievoorziening gaat onder andere in op informatiebeleid, informatieplanning, de inrichting van de informatievoorziening, de ontwikkeling van informatiesystemen en de beheersingsaspecten van automatiseringsmiddelen. Auditing is een cursus 
waarin studenten een overzicht krijgen van de taak en functie van de accountant. Daarnaast worden de meest elementaire accountantsmethoden en -technieken behandeld. Fiscaal Recht I en II behandelen het winstgedeelte van de inkomstenbelasting, de vennootschapsbelasting, de loonbelasting, de omzetbelasting en het internationale belastingrecht. In de cursus Externe Berichtgeving II wordt onder andere besproken wat het effect kan zijn van bijvoorbeeld een hoge winst in de jaarrekening op de beslissingen van de gebruikers van die jaarrekening. Verder zal aan de orde komen welke gevolgen het door managers gekozen waarderingsstelsel kan hebben.

Is dit doctorale programma met goed gevolg afgelegd en heeft de student het landelijk schriftelijk examen AO gehaald dan kan de postdoctorale opleiding tot Registeraccountant gevolgd worden. Tegelijkertijd zal de exuniversitaire student als assistent bij een accountantskantoor kunnen gaan werken ${ }^{7}$.

In Maastricht krijgen studenten die het postdoctorale programma volgen als eerste een integratieblok tussen $A O$ en Leer van de Accountantscontrole (LAC). Vervolgens worclen cursussen gegeven als Leer van de Accountantscontrole en Externe Berichtgeving.

In het vak. AO-LAC wordt vanuit het vak Administratieve Organisatie, door de studenten in het doctorale programma gevolgd, een koppeling gemaakt naar het nieuwe vak Leer van de Accountantscontrole. Specifieke onderwerpen als automatisering en risico-analyse worden hierin behandeld. Tijdens het vak Leer van de Accountantscontrole zullen de verschillende controlemethodes, controletechnieken en de daarachter liggende theorieèn worden besproken. Bij het vak Externe Berichtgeving zullen die zaken aan de orde komen die actueel zijn bij de wettelijke controle van de jaarrekening.

Het postdoctorale programma wordt afgesloten met een landelijk schriftelijk examen over de Leer van de Accountantscontrole. Daarnaast wordt er door de postdoctorale docenten een mondeling examen over Leer van de Accountantscontrole en over een door de studenten geschreven paper van 10 à 15 pagina's afgenomen.

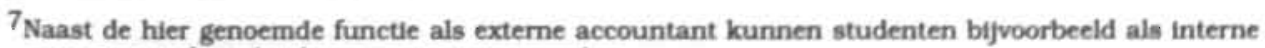
accountant of overheidsaccountant gaan werken.
} 
Tabel 1.3 Opleidingsprogramma voor het Registeraccountantstraject aan de Rijksuniversiteit. Limburg (Studiegids Faculteit der Economische Wetenschappen, 1994/1995).

\begin{tabular}{|c|}
\hline Eerste studiejaar (Propaedeuse) \\
\hline $\begin{array}{l}\text { Marketing \& Organisatie } \\
\text { Micro-economie } \\
\text { Macro-economie } \\
\text { Financiering \& Berichtgeving } \\
\text { Practica: Informatica, Statistlek, Wiskunde \& Financiêle Informatiesystemen } \\
\text { Vaardigheden: Schrijfvaardigheden }\end{array}$ \\
\hline Tweede studiejaar (Basisdoctorale programma) \\
\hline $\begin{array}{l}\text { Informatiekunde } \\
\text { Berichtgeving } \\
\text { Financiering } \\
\text { Organisatie } \\
\text { Marketing } \\
\text { Gedrags- en Maatschappljwetenschappen/Recht } \\
\text { Practica: Kwantitatieve methoden, Financiêle informatiesystemen }\end{array}$ \\
\hline $\begin{array}{c}\text { Derde studiejaar8 } \\
\text { (Doctorale Programma Berichtgeving/Accountancy) }\end{array}$ \\
\hline $\begin{array}{l}\text { Voortgezette Financiele Informatie Systemen } \\
\text { Interne berichtgeving } \\
\text { Financieel management I } \\
\text { Externe berichtgeving I } \\
\text { BIV/AO-I } \\
\text { Financièle en actuariele wiskunde } \\
\text { Keuzevakken (twee vakken Algemene Economie) } \\
\text { Vaardigheid: Administratieve organisatie en schematechnieken } \\
\text { Vaardigheid: Ontwerpen van een expertsysteem t.b.v. bedrijfsdiagnose } \\
\text { Vaardigheid: het gebruik van de PC bij financieell economische } \\
\text { beslissingscalculaties }\end{array}$ \\
\hline Vierde studiejaar \\
\hline $\begin{array}{l}\text { BIV/AO-II } \\
\text { Internationale externe berichtgeving } \\
\text { Management en informatievoorziening } \\
\text { Ondernemingsrecht } \\
\text { Auditing } \\
\text { Externe berichtgeving II } \\
\text { Fiscaal recht I } \\
\text { Fiscaal recht II } \\
\text { Vaardigheid: Ontwerpen van financiēle informatiesystemen } \\
\text { Vaardigheid: Communicatieve vaardigheden in accountancy } \\
\text { Vaardigheid: Financiêle analyse en cijferbeoordeling } \\
\text { Afstudeerscriptie }\end{array}$ \\
\hline
\end{tabular}

\footnotetext{
8 Studenten die op de HEAO het accountantstraject hebben gevolgd kunnen instromen in het derde studiejaar van het doctoraal programma.
} 
Vervolg Tabel 1.3

\begin{tabular}{|c|}
\hline $\begin{array}{c}\text { Vijfde studiejaar }{ }^{9} \\
\text { (Postdoctorale Registeraccountancy-opleiding) }\end{array}$ \\
\hline $\begin{array}{l}\text { AO-Leer Accountantscontrole } \\
\text { Leer Accountantscontrole } \\
\text { Externe berichtgeving } \\
\text { Paper }\end{array}$ \\
\hline
\end{tabular}

De postdoctorale opleiding tot Registeraccountant kan eveneens bij een aantal andere universiteiten worden gevolgd en wel aan de Erasmus Universiteit Rotterdam, de Katholieke Universiteit Brabant, de Rijksuniversiteit Groningen, de Vrije Universiteit en de Universiteit van Amsterdam. Het verschil tussen Maastricht en de andere universiteiten is dat in Maastricht het AO-examen al voor de aanvang van het postdoctorale programma gehaald moet zijn. Studenten kunnen wel voorwaardelijk worden toegelaten mits ze het najaarsexamen in $\mathrm{AO}$ halen. Bij de meeste andere universiteiten geldt de regel dat het $\mathrm{AO}$ examen in het eerste jaar van de postdoctorale opleiding gedaan wordt. Daardoor zou de postdoctorale studie in Maastricht in één tot twee jaar afgerond kunnen worden; de postdoctorale opleidingen bij de andere universiteiten nemen twee tot drie jaar in beslag.

\section{Vergelijking van opleidingen}

Dit overzicht van de curricula van zowell de HEAO's, de NIVRA= Nijenrode deeltijdopleiding als de full-time opleiding aan de Rijksuniversiteit Limburg (RL) laat zien dat er veel overeenkomsten tussen de aangeboden cursussen zijn. In alle curricula is de opbouw van de opleidingen van breed en inleidend in het eerste studiejaar naar specifiek gericht op het accountantsberoep in de latere studiejaren. Het verschil tussen HEAO enerzijds en NIVRA-Nijenrode en RL anderzljds is, dat de HEAO slechts een deelopleiding verzorgt. HEAO studenten stromen, als ze Registeraccountant willen worden, na hun eindexamen door naar de tweede fase van de NIVRANijenrode opleiding of naar het doctorale programma van één van de reguliere universiteiten.

De uniforme landelijke examens Administratieve Organisatie en Leer van de Accountantscontrole die zowel de NIVRA-Nijenrode als de andere

\footnotetext{
${ }^{9}$ NIVRA studenten kunnen direct het postdoctoraal programma voigen mits zij alles behalve Leer van de Accountantscontrole en de afstudeerscriptie gehaald hebben.
} 
universitaire studenten moeten afleggen en de vakken die in het programma van het NIVRA-Nijenrode en de RL aan de orde komen geven aan dat deze twee opleidingen vrijwel identiek zijn. Dat wordt nog eens bevestigd door het gemak waarmee NIVRA-studenten voldoen aan de eisen van de postdoctorale opleiding van de universiteiten. Het verschil is dat de NIVRA-studenten wanneer zij instromen in de postdoctorale opleiding, gemiddeld viff tot zeven jaar werkervaring hebben, terwijl de universitair afgestudeerden op het moment van instroom hooguit twee maanden in de praktijk werken. Hoewel de diploma's op dat moment gelijkwaardig zijn kan men zich afvragen of de accountancy studenten die de verschillende trajecten hebben gevolgd dezelfde kennis en vaardigheden hebben opgedaan. Volgens Schōn (1987) en Harris (1993) zal een student die theoretische kennis direct in praktijk brengt en daarnaast gecoached wordt door een ervaren iemand, veel beter in staat zijn om met de ingewikkelde complexe problemen van de praktijk om te gaan. Het verwerven van theoretische kennis naast praktijkervaring is volgens Schön wel degelijk lets anders dan het verwerven van theoretische kennis zonder dat er gelegenheid is die in praktijk te brengen.

Uit een aantal onderwijsprogramma's van het NIVRA blijkt dat NIVRAstudenten de theorie inderdaad vrijwel onmiddellijk in de praktijk kunnen brengen. Bijvoorbeeld bij Belastingrecht I, één van de eerste cursussen van de NIVRA opletding, komen de belangrijkste aspecten van de loon- en omzetbelasting aan de orde " onderwerpen waarmee de meeste studenten in de praktijk al regelmatig in aanraking zijn gekomen (NIVRA, 1993a). Ook de eerstejaars cursus Inleiding in de Bestuurlijke Informatieverwerking van het NIVRA sluit goed aan op de werkzaamheden die de NIVRA-studenten spoedig zullen verrichten (NIVRA, 1993b).

De NIVRA-studenten verwerven dus theoretische kennis tegelijkertijd met het opdoen van praktijkervaring. Zij hebben daardoor de mogelijkheid om theoretische kennis direct toe te passen in de praktijk. De opgedane theoretische kennis blijft zo niet alleen bij feiten en abstracte theorieên maar kan vrijwel onmiddellijk worden omgezet in toegepaste concrete kennis. De unlversitair opgeleide studenten daarentegen hebben tot aan het postdoctorale programma nauwelijks kans gehad om de theoretische kennis in praktijk te brengen. Verwacht kan worden dat de studenten die geen ervaring hebben opgedaan minder in staat zullen zijn om de verworven kennis toe te passen op praktijksituaties. 
De vraag die hier aan de orde is, is of praktijkervaring van invloed is op het verwerven en gebruik van kennis. Maakt het uit of studenten, zoals Schōn (1987) stelt, naast theoretische kennis praktijkervaring opdoen of zijn er geen verschillen tussen groepen met en zonder praktijkervaring.

In het volgende hoofdstuk zullen de theoretische en empirische opvattingen over de invloed van praktijkervaring en de ontwikkeling van expertise in het accountancydomein aan de orde komen. 
- 30 - 


\section{De invloed van praktijkervaring oftewel \\ de ontwikkeling van expertise}

In dit tweede hoofdstuk zijn vier verschillende onderzoeksparadigma's beschreven die zich gericht hebben op de studie naar expertise en expertiseontwikkeling. Voordat deze benaderingen aan de orde komen, zal het begrip expertise worden verduidelijkt. Daarna worden achtereenvolgens besproken: studies vanuit Brunswik's Lensmodel, studies naar heuristieken, studies naar het cognitieve redeneerproces en studies waarin de relatie tussen 'expertise' en 'kennis en kennisstructuur' is onderzocht. Dit hoofdstuk besluit met de formulering van vier onderzoeksuragen die in dit proefschrift op basis van empirisch onderzoek getoetst zullen worden.

\section{Inleiding}

Oefening baart kunst, anders gezegd 'practice makes perfect'. Vele onderzoekers zijn de overtuiging toegedaan dat personen door het opdoen van ervaring en het vaak uitvoeren van handelingen expert zullen worden (Fitts. 1964; Neves \& Anderson, 1981; Newell \& Rosenbloom, 1981). Niet ledereen is het echter met die opvatting eens. Camerer en Johnson (1991) bijvoorbeeld stellen dat studies die zijn uitgevoerd in domeinen als de klinische psychologie, de geneeskunde en het verzekeringswezen laten zien dat academische training wel tot verbetering van de prestatie leidt, maar dat praktijkervaring daar nauwelijks iets aan toevoegt.

\section{Expertise}

Over het algemeen neemt men aan dat experts, juist doordat ze veel praktijkervaring hebben opgedaan, snel, effliènt en effectief zullen handelen binnen hun vakgebied. Bovendien ziet men experts als vakbekwame personen die doorgaans betere prestaties leveren dan niet- 
experts (Boshuizen, 1989). Wanneer expertise echter nader gedefinieerd moet worden, komen er vragen op als: hoeveel praktijkervaring moet een persoon eigenlijk hebben, hoe vaak moeten er uitmuntende prestaties geleverd worden en hoe uitmuntend moeten die prestaties zijn? Anders gezegd, wanneer is lemand nu precies een expert?

Op basis van wetenschappelijk onderzoek is inmiddels meer inzicht verkregen in de aard en ontwikkeling van expertise. Hayes (1981), Ericsson en Crutcher (1990) en Simon en Chase (1973) geven bijvoorbeeld aan dat tien jaar praktijkervaring binnen domeinen als schaken, sport en wetenschap voldoende is om in het betreffende vakgebied een expertise-niveau te bereiken.

Andere onderzoekers, met name op het gebied van de accountancy, betwisten of aantal jaren praktujkervaring wel de beste voorspeller is voor expertise. Onderzoekers als Abdolmohammadi en Wright (1987) suggereren bijvoorbeeld dat de mate van taakcomplexiteit waarmee men in aanraking is geweest meer bepalend is voor het verwerven van expertise dan praktijkervaring in het algemeen. Bonner $(1990,1994)$ en Bonner en Lewis (1990) maken een duidelijk onderscheid tussen algemene ervaring en specifieke taakervaring. Zif veronderstellen dat ervaring met specifieke accountancytaken een betere voorspeller is voor accountancy-expertise dan praktijkervaring in het algemeen. Een accountant die bijvoorbeeld vaker cijferanalyses heeft uitgevoerd dan een andere accountant zal meer expert zijn op het gebled van cijferanalyse dan diegene die minder met cijferanalyses te maken heeft gehad.

Naast specieke taakervaring is er door Ashton (1991) en Bedard en Biggs (1991a) nagegaan of specifleke ervaring met een bepaald type bedrijf niet een betere voorspeller was dan ervaring in het gehele accountancydomein. Volgens Ashton (1991) bleek het subdomein. minder van belang te zijn dan verwacht, terwijl Bedard en Biggs (1991a) vonden dat ervaring met een specifiek subdomein hoger correleerde met een verbeterde prestatie dan ervaring in het algemeen.

In dit proefschrift is de keuze gemaakt om de opvatting over expertise van gerenommeerde onderzoekers als Hayes (1981), Ericsson. en Crutcher (1990) en Simon en Chase (1973) te volgen. Expertise wordt in dit proefschrift dan ook gezien als een functie van het aantal jaren praktijkervaring en zal gedefinieerd zijn als: de deskundigheid die wordt bereikt na een tiental jaren praktijkervaring binnen de accountancy. 
Hierbij wordt niet uitgesloten dat accountants die veel ervaring hebben opgedaan met een bepaald type bedrijf of met specifleke taken, meer expert zijn binnen die specifieke branche of ten aanzien van die specifieke taken dan accountants die daar minder of geen ervaring mee hebben.

\section{Studies vanuit Brunswik's Lensmodel}

Midden jaren zeventig werd in het accountancydomein voor het eerst onderzoek gedaan naar eventuele verschillen tussen experts en niet-experts. Het onderzoeksparadigma van waaruit deze expertiseverschillen werden onderzocht was Brunswik's Lensmodel ${ }^{9}$. Aan de hand van het Lensmodel trachtten onderzoekers te achterhalen of er een positief verband bestond tussen mate van accountancy-expertise en een aantal aspecten die belangrijk worden geacht voor het accountantsoordeel zoals: consensus, stabiliteit, accuratesse en zelfinzicht. Men verwachtte dat een expert door de opgedane praktijkervaring beter zou presteren en meer inzicht zou hebben in zijn gedrag dan nlet-experts. Eveneens werd verwacht dat experts door hun ervaring beter in staat zouden zijn om op consistente wijze beslissingen te nemen dan minder ervaren accountants.

Expertisestudies in dit paradigma werden als volgt uitgevoerd: experts en niet-experts kregen een casus aangeboden die vijf tot acht relevante items en een aantal 'fillers' bevatte. Relevante items waren bijvoorbeeld financiēle ratio's of interne controleprocedures die van belang waren om tot het uiteindelijke oordeel te komen. Flllers waren gegevens in de casus die niet of nauwelijks van belang waren voor de uiteindelijke beoordeling. Na de casus bestudeerd te hebben, dienden proefpersonen een oordeel te geven over bijvoorbeeld het interne controlesysteem. Daarna werd aan de proefpersonen gevraagd om de items te ordenen naar belangrijkheid. De afhankelifke variabelen waren: consensus tussen personen, stabiliteit binnen personen, zelfinzicht en de accuratesse van het uiteindelijke oordeel. Aan de hand van regressievergelijkingen tussen items, gegeven oordelen en verwachte oordelen werd getracht na te gaan in hoeverre experts meer consensus en meer

9 Dit onderzoeksmodel is genoemd naar de bedenker van het Lens model, Egon Brunswik. 
inzicht zouden vertonen en stabieler en accurater zouden zijn dan de minder ervaren accountants.

Uit een literatuuroverzicht van Bédard (1989) blijkt dat de voorspelde verschillen in consensus, stabiliteit en inzicht in de meeste Lens-studies nauwelijks gevonden werden. De relatie tussen ervaring en consensus bieek bijvoorbeeld niet consistent te zijn. Ook stabiliteit van de beslissing over de tijd en de variabelen 'zelfinzicht' en 'belangrijkheid van items' hielden nauwelijks verband met ervaringsniveau (Bêdard, 1989). Een positieve uitzondering was accuratesse van het uiteindelijke oordeel. Deze varlabele gaf onder andere bij Boritz et al., (1987), Nanni (1984) en Tabor (1983) een significant resultaat te zien, in die zin dat bij ervaren accountants een hogere overeenstemming werd gevonden tussen gegeven en verwacht oordeel dan bij novieten (Ashton, 1982; Bédard, 1989; Libby, 1982).

De Lensstudies hebben dus niet de voorspelde resultaten opgeleverd (voor een overzicht van de studies, zie Tabel 2.1). Consensus, stabilitelt en belangrijkheid van items bleken niet of nauwelijks toe te nemen met toenemende ervaring. De enige variabele die uit deze selectie van onderzoeken een consistent resultaat opleverde was de kwaliteit van de beoordeling. Deze beoordeling bleek accurater te worden als praktijkervaring toenam. Waardoor die kwaliteitsverschillen in de uiteindelijke beoordeling werden veroorzaakt bleek op basis van deze studies echter nauwelijks te beantwoorden.

Hoe dat uiteindelijke oordeel tot stand kornt is object geweest in latere studies. Daarbij werd door sommige onderzoekers verondersteld dat de meer accurate oordelen van experts verklaard konden worden vanuit een beter gebruik van heuristieken. Andere onderzoekers meenden dat de verschillen in expertise veroorzaakt werden door de wijze waarop het redeneerproces verloopt. Een derde groep zag verschillen in kennishoeveetheid en in kennisorganisatie als mogelijke verklaring voor de verschillen in de uiteindelijke beslissing. Deze drie benaderingen zullen in het navolgende in detail besproken worden. 


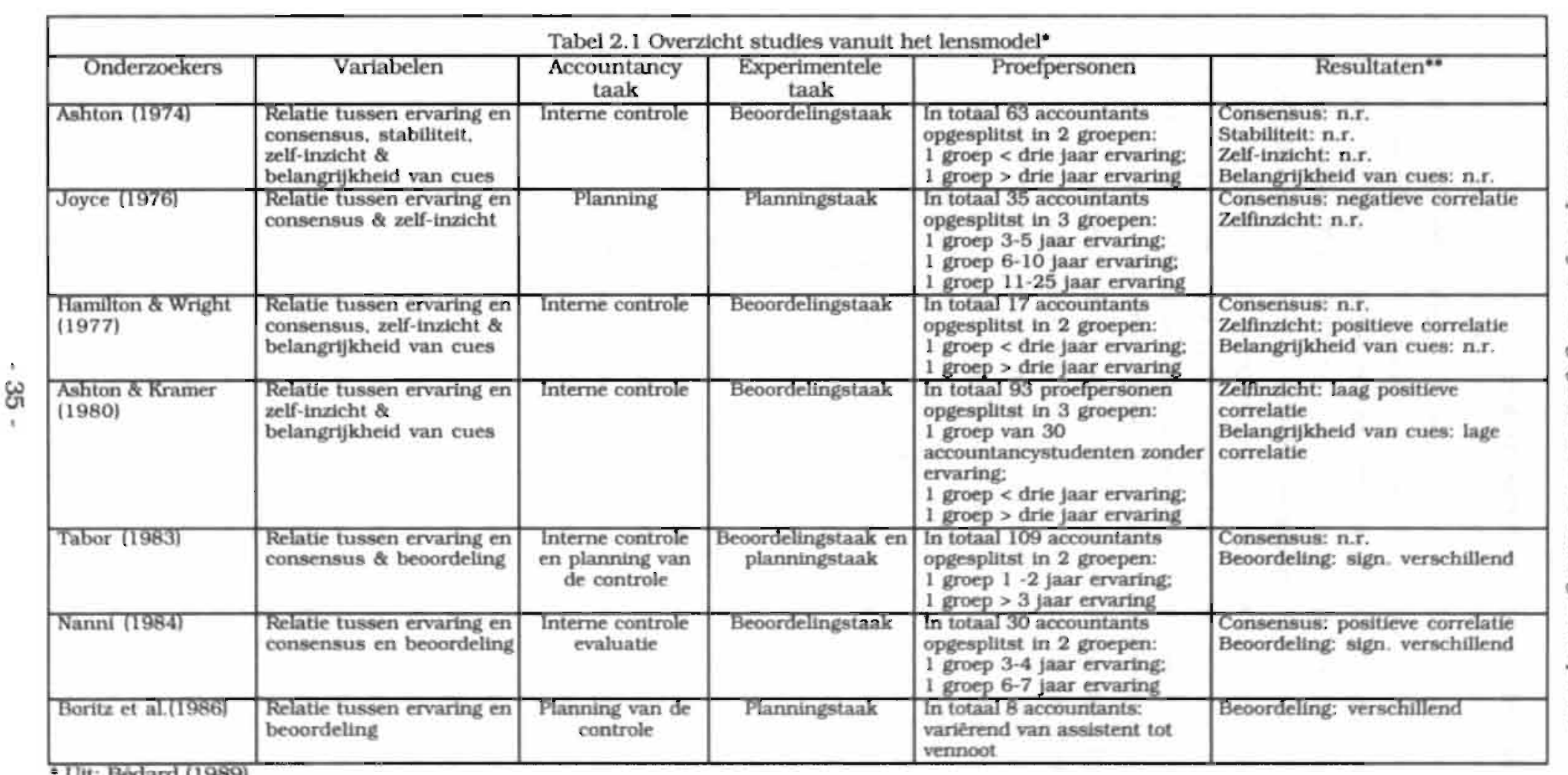

" n.r. betekent niet gerelateerd. 


\section{Studies naar de rol van heuristieken}

In de jaren tachtig werd er voor het eerst aandacht besteed aan de relatie tussen expertise en het gebruik van heuristieken in de accountancy. Deze nieuwe lijn van onderzoek was geïnspireerd door onderzoek van Kahneman en Tversky (1972) en Tversky en Kahneman (1973, 1974). Dit onderzoek vloeide voort uit de constatering dat mensen geen beslissingen namen volgens objectieve statistische kansschattingsregels, maar dat beslissingen voor een groot deel werden genomen op basis van intuïtieve heuristieken of vuistregels (Kahneman \& Tversky, 1972). Volgens Kahneman en Tversky hanteren mensen een drietal heuristieken die van invloed zljn op het nemen van beslissingen. De eerste vuistregel, 'de representativiteitsheuristiek', houdt in dat er een oordeel wordt gevormd aan de hand van de overeenkomst van iets of iemand met een stereotypevoorbeeld (prototype) van dat geval. Dus als een accountant ter kennismaking bij een nieuw bedrijf komt dat tot een bedrijfscategorle behoort waarvan het stereotypebeeld bestaat dat de administratieve organisatie in dat soort bedrijven altijd goed georganiseerd is, dan zal de accountant waarschijniljk geneigd zijn aan te nemen dat de administratieve organisatie bij het nieuwe bedrijf ook goed georganiseerd is. De tweede vulstregel is 'de beschikbaarheidsheuristlek'. Dit wil zeggen dat hoe vaker iets is voorgekomen en hoe indrukwekkencier dit verschijnsel is geweest, des te groter de kans is dat degene die een oordeel moet geven erdoor wordt beïnvloed. Bijvoorbeeld: het regelmatig voorkomen van forse onregelmatigheden in de post 'onderhanden werk' zal tot gevolg hebben dat een accountant eerder verwacht dat er iets aan de hand is met de post 'onderhanden werk' dan met een post waar minder vaak lets mee aan de hand is en waarbij de onregelmatigheden minder groot zijn. De derde en tevens laatste vuistregel is 'aanpassing en verankering'. Deze vuistregel houdt in dat mensen geneigd zijn hun oordeel af te stemmen op de oordelen die eerder gegeven zijn (Tversky \& Kahneman, 1974, 1975). Bij een accountantscontrole kan je dan denken aan de controle die dit boekjaar wordt uitgevoerd en die wordt beïnvloed door de controle-aanpak van vorige jaren.

In de accountancy hebben Frederick en Libby (1986) een aantal studies uitgevoerd, waarin werd onderzocht of er een verband bestond tussen mate van expertise en het gebruik van de 'representativiteitsheuristiek'. De proefpersonen die deelnamen aan de 
studies waren doctoraal accountancystudenten, MBA studenten en accountants met 2,5 tot 3.5 jaar ervaring. Proefpersonen bestudeerden eerst een scenario en brachten vervolgens een rangorde aan binnen een lijst factoren die al dan niet negatieve consequenties voor de jaarrekening zouden kunnen hebben. Dat wil zeggen: hoe hoger de proefpersonen de kans daarop inschatten hoe hoger de factor op de lijst. kwam. De scenario's die de proefpersonen aangeboden kregen waren de volgende:

Scenario 1:

Open Company has engaged your office to perform the current year audit. While this is the twenty-second year that the office has had Open Company as an audit client, this is your first year of engagement. However, you know, from reviewing prior year work papers, that the systems of internal accounting and control have been relied upon in past audits.

The current year documentation, review, and update of the internal accounting and control systems (of Open Company) has disclosed that: (1) due to heavy personnel attrition, independent operations of sales, shipping, billing. and accounts receivable departments could not be achieved: (2) no regular aging of acoounts recetvable was performed: (3) there was no independent mathematical check of sales invoices for accuracy pricing, quantities, and extensions.

\section{Scenario 2:}

Open Company has engaged your office to perform the current year audit. While this is the twenty-second year that the office has had Open Company as an audit client, this is your first year of engagement. However, you know, from reviewing prior year work papers. that the systems of internal accounting and control have been relied upon in past audits.

The current year documentation review and update of the internal accounting and control systems (of Open Company) has disclosed that: (1) due to heavy personnel attrition. independent operation of cash receipts function and accounts receivable record. keeping function could not be achieved: (2) no regular follow-up of overdue acoounts was: performed; (3) there was no independent comparison of the cash depostt stips with the initial cash control record.

Het eerste scenario was volgens Frederick en Libby prototypisch voor een intern controlesysteem waarin beoordelaars zeer waarschijnlijk fouten zouden verwachten in de verkoopregistratie (sales recording errors) die weer de verwachting met betrekking tot de posten 'verkoopopbrengsten' (sales revenue) en de 'vorderingen' (accounts receivable) zouden beïnvloeden. In dit eerste scenario zouden de posten 'netto-vorderingen' (net accounts receivable) en 'verkoopbedragen' (sales 
amounts) beide negatief beïnvloed worden door de prototypische fout 'verkoopregistratie'. Frederick en Libby namen dan ook aan dat als dit scenario werd aangeboden, de combinatie van 'netto-vorderingen' (net accounts receivable) en 'verkoopbedragen' (sales amounts) hoger in de rangorde betreffende negatieve consequenties voor de jaarrekening zou staan dan de fouten 'netto-vorderingen' (net accounts receivable) en 'verkoopbedragen' (sales amounts) afzonderlijk. Reden was dat het scenario automatisch beide fouten zou oproepen, omdat het scenario was geschreven volgens een stereotype situatie waarin de combinatie vaak voorkwarn.

In het tweede scenario werd een prototypisch intern controlesysteem beschreven waarin beoordelaars zeer waarschijnlijk fouten zouden verwachten als: fouten in de 'kasopbrengsten-registratie' (cash receipts recording emors) die de balansposten 'vorderingen' (accounts receivable) en 'kas' (cash) beïnvloedden. In dit scenarto waren fouten in de posten 'vorderingen' (accounts receivable) en 'kasopbrengsten (cash receipts) de te verwachten consequentie van de prototypische uitkomst van het scenario. In dit tweede scenario zou dus met name de combinatle van 'netto-vorderingen' (net accounts receivable) en 'kas' (cash) een hogere kansschatting op negatieve consequenties voor de jaarrekening krijgen dan 'netto-vorderingen' (net accounts receivable) en 'kas' (cash) afzonderlijk. Wat Frederick en Libby verwachtten was dat experts, in tegenstelling tot onervaren accountants. de combinaties van fouten uit het aangeboden scenario zouden kunnen koppelen aan mogelijke negatieve consequenties voor te verwachten fouten in de jaarrekening.

Om dit te kunnen achterhalen werden de experimenten als volgt opgezet: proefpersonen kregen bijvoarbeeld 'scenario $l$ ' aangeboden en dienden dit te evalueren op mogelijke fouten en onvolkomenheden. Daarna konden de proefpersonen aan twee condities toegewezen worden: één conditie waarbij de rangordelijst twee prototypische fouten bevatte en één conditie waarbij de rangordelijst één prototypisische fout ('vorderingen') en één niet-prototypische fout (hier 'kas') bevatte. Als de veronderstellingen van Frederick en Libby op zouden gaan, dan zou dat betekenen dat, als de rangordelijst twee fouten bevatte die prototypisch waren voor 'scenario I' ('vorderingen' en 'verkoopbedragen'), experts hogere schattingen van kansen zouden geven aan de combinatie van fouten dan aan de twee afzonderlijke fouten. Bevatte de rangordelijst slechts één prototypische ('vorderingen') en één niet-prototypische fout 
('kas'), dan zouden de experts de combinatie een hogere schatting moeten geven dat deze een negatieve invloed heeft op de jaarrekening dan één van de fouten afzonderlijk. De onervaren accountants werden verondersteld geen kennis van de relatie tussen fouten in de interne controle procedures en de jaarrekening te hebben. Zij zouden dan ook ongeacht welk scenario ze hadden gelezen, de kans op de combinatie van fouten altijd hoger schatten dan één van de fouten afzonderlijk. De resultaten uit de experimenten bevestigden de voorspellingen van Frederick en Libby. De experts gaven andere ordeningen van kansschattingen na prototypische dan na niet-prototypische fouten. Daarentegen werden de onervaren accountants niet verschillend beïnvloed door de verschillende types fouten.

Naar aanleiding van de gevonden verschillen tussen experts en onervaren accountants concludeerden Frederick en Libby dat alleen de ervaren accountants een kennisbestand bezaten waarin relaties tussen zwakheden in de interne controle en fouten in de financièle jaarrekening weergegeven waren. Onervaren studenten hadden volgens hen daarentegen een kennisbestand waarin slechts relaties tussen posten in de jaarrekeningen gerepresenteerd waren. Deze interpretatie laat overigens zien dat Frederick en Libby (1986) niet alleen oog hadden voor verschillen in het gebruik van de 'representativiteitsheuristiek' maar eveneens voor verschillen in kennisrepresentaties.

\section{Studies naar het cognitieve redeneerproces}

Eveneens in de jaren tachtig kwam er belangstelling voor het cognitieve redeneerproces dat voorafgaat aan het uiteindelijke oordeel. In tegenstelling tot het gebruik van normatieve statistische modellen was deze aanpak meer beschrijvend van aard. Voorlopers waren Newell en Simon (1972) die veronderstelden dat als mensen problemen oplosten, zij daarbij tamelijk algemene oplossingsstrategleên hanteerden. Om te achterhalen welke strategieèn mensen gebruikten bij het oplossen van problemen vroegen Newell en Simon proefpersonen hardop te denken terwijl ze een probleem aan het oplossen waren. Volgens Newell en Simon doorliepen probleemoplossers een probleem-

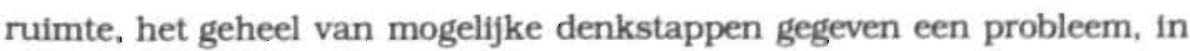
drie fases: een beginfase waarin het probleem werd geschetst, een aantal tussenliggende fases waarin stapsgewijs via tussenoplossingen naar de. 
uiteindelijke oplossing werd gewerkt en de laatste fase waarin de uiteindelijke oplossing werd verkregen. Newell en Simon (1972) veronderstelden dat, terwijl mensen een probleem oplosten zij de tussenstappen, ook wel operaties genoemd, konden verwoorden waardoor de onderzoekers een duidelijk beeld konden krijgen van het redeneerproces.

Elstein, Shulman en Sprafka (1978) en Einhorn en Hogarth (1981) hebben de benadering van Newell en Simon (1972) die gebruikt werd om het oplossen van relatief eenvoudige taken te beschrijven toegepast op meer complexe taken. In het hypothese-genereermodel van Elstein et al. (1978) werd het redeneerproces opgedeeld in de vier fases: verwerving van feiten, voorlopige hypotheses, hypothese interpretatie en hypothese-evaluatie. Einhorn en Hogarth (1981) deelden het redeneerproces eveneens op in vier, zij het, andere fases: informatieverwerving, informatie evaluatie, actie en feedback/leren.

Naar aanleiding van deze procesmatige aanpak van menselijk redeneren zijn een aantal expertisestudies in de accountancy gedaan. Bouwman $(1978,1984)$ bijvoorbeeld deed een onderzoek naar verschillen tussen het redeneerproces van ervaren accountants en die van onervaren accountancy studenten bij het maken van een financiële analyse. Aan beide onderzoeken namen twee groepen proefpersonen deel: onervaren studenten en ervaren accountants. De proefpersonen werd gevraagd hardop te denken terwijl ze een jaarrekening doornamen. De hardopdenkprotocollen werden in drie fases ingedeeld: de beginfase 'onderzoek van informatie', vervolgens de fase 'integratie van informatie en bevindingen' en als laatste de redeneerfase. Resultaten lieten zien dat ervaren accountants en onervaren studenten weinig verschllden in de beginfase: het onderzoeken van informatie. Belde groepen vertaalden de financiêle informatie in kwalitatieve termen. Wel was er een verschil in de manier waarop de groepen de informatie doornamen. De studenten namen het materiaal op een sequentiële wijze door, terwijl de experts de informatie meer aan de hand van een gestructureerde checklist leken door te nemen. Daarnaast hadden experts, in tegenstelling tot de onervaren studenten, een 'feeling' voor het beschreven bedrijfstype ontwikkeld. Bouwman geeft verder niet aan wat hij met 'feeling' bedoelt. Voor de tweede fase geldt dat de studenten alleen die bevindingen probeerden te koppelen die elkaar zouden kunnen verklaren. Potentiële contradicties werden daarbij over het hoofd gezien. Ervaren accountants daarentegen legden de nadruk op de contradicties 
in de financiēle gegevens. In de redeneerfase werd de uiteindelijke beslissing geformuleerd. In deze fase hadden novieten moeite om te beslissen welk feit als het belangrijkste probleem aangegeven moest worden. De ervaren accountants vatten in deze fase de gerelateerde gegevens samen en trachtten hypotheses te formuleren. Daarnaast gebruikten de ervaren accountants een lijst van typische problemen die leidden tot meer algemene conclusies.

Ook Biggs, Mock en Watkins (1988) onderzochten of er verschillen bestonden tussen ervaren en onervaren accountants ten aanzien van het redeneerproces. $\mathrm{Zij}$, hadden het redeneerproces opgedeeld in de drie informatieverwerkingsfases: informatieverwerving, informatie-evaluatie en actie/keuze. Er deden vier proefpersonen aan het onderzoek mee: twee ervaren accountants die de functie van manager bekleedden en twee die seniors waren. Het onderzoeksmateriaal bestond uit een casus van 100 bladzijden waarin de nog niet gecontroleerde jaarrekening van een handelsfirma werd beschreven. Er waren in totaal twee experimentele sessies. De eerste sessie hield in dat de proefpersonen de casus dienden te controleren en een controleprogramma moesten voorbereiden voor een nog uit te voeren cijferanalyse. In de tweede sessie kregen de proefpersonen de gevraagde financiële gegevens en dienden ze het geplande controleprogramma te checken. In beide sesstes werd hun gevraagd hardop te denken. Biggs et al. (1988) deelden de protocollen van de eerste sessie in naar de drie informatieverwerkings-fases en concludeerden dat in de eerste fase, de informatieverwervings-fase, de meer ervaren managers veel minder gebruik maakten van het introductiemateriaal over casusinstructie en controleprocedures dan de minder ervaren seniors. Seniors bleken meer dan $32 \%$ informatie te halen uit de introductie van de casus, terwijl managers slechts $12,5 \%$ informatie haalden uit het introductiemateriaal. Volgens Biggs et al. (1988) gaf dat verschil in informatieverwerving aan dat ervaren accountants schemata van dit type bedrijf in het geheugen hadden opgeslagen en onervaren accountants niet. In de informatie-evaluatiefase kwamen geen verschillen tussen de ervaren en minder ervaren accountants naar voren. De derde fase waarin een actie/keuze moest worden gemaakt bestond uit twee subfases. In de eerste subfase werd aan de accountants gevraagd mogelijke problemen aan te geven die in de casus zaten. De managers signaleerden in deze fase fets meer problemen dan de seniors. In de tweede subfase moesten de proefpersonen aangeven of ze het controleprogramma zouden aanpassen. In deze tweede subfase 
kwamen geen verschillen tussen de managers en de seniors naar voren. Ten aanzien van de tweede experimentele sessie bleken er nauwelijks verschillen te bestaan tussen managers en seniors. Zowel managers als seniors stemden in deze tweede sessie de beslissingen af op de verkregen financiẽle gegevens.

Libby en Frederick (1990) deden eveneens een studie naar de verschillen in het redeneerproces tussen ervaren en onervaren accountants. Zij verwachtten dat ervaren accountants beter in staat zouden zijn om vanuit veranderingen in financiële ratio's plausibele onregelmatigheden in de jaarrekening te kunnen bedenken dan minder ervaren accountants. Verder verwachtten ze dat ervaren accountants efficiënter zoekgedrag zouden vertonen en meer potentiële onregelmatigheden met dezelfde kenmerken zouden clusteren dan minder ervaren accountants. Dit clusteren van potentiēle onregelmatigheden zou moeten blijken uit de bevinding, dat ervaren accountants, in tegenstelling tot de andere twee groepen, wel beỉnvloed zouden worden door de aanbieding van een typisch of atypisch item ${ }^{10}$. Aan het onderzoek deden proefpersonen met drie verschillende ervaringsniveaus mee: een groep studenten die geen ervaring had, stafleden met een mediaan van één jaar ervaring en managers met een mediaan van vijf jaar ervaring. De proefpersonen hadden als taak veranderingen in financiële ratio's te verklaren. Het casusmateriaal werd in drie vormen aangeboden: men kon informatie zonder onregelmatigheden aangeboden krijgen, men kon een typische onregelmatigheid aangeboden krijgen of men kon een atypische onregelmatigheid uit een mutatiestroom gepresenteerd krijgen.

Zoals voorspeld lieten de resultaten zien dat de managers een grotere hoeveelheid plausibele hypotheses genereerden dan de minder ervaren groepen. Daarnaast genereerden de managers significant meer hypotheses die overeenkwamen met in de praktijk frequenter voorkomende onregelmatigheden dan de studenten. Dit verschil was niet te vinden tussen managers en stafleden. Een laatste resultaat was dat de groep studenten niet werd beînvloed door het wel of niet aanbieden van een onregelmatigheid, terwijl de assistenten en managers met name na een atypische onregelmatigheid, hypotheses omtrent onregelmatigheden genereerden die uit dezelfde mutatiestroom kwamen.

10 Typiciteit wordt door Lbby en. Frederick (1990) opgevat als de frequentie waarin iets voorkomt. Dat wil zeggen, hoe vaker lets is voorgekomen des te typischer het is. 
Libby en Frederick (1990) concludeerden uit deze laatste bevinding dat de kennis van ervaren accountants georganiseerd was naar mutatiestromen.

Bedard en Biggs (1991) onderzochten of er een relatie bestond tussen het genereren van hypotheses en de kwaliteit van een oordeel. Aan het onderzoek deden twaalf seniors en tien managers mee. De taak voor de proefpersonen was om hardop redenerend een fout uit de aangeboden financièle informatie te halen. De onderzoekers waren met name geînteresseerd in de eerste hypotheses die de proefpersonen zouden noemen tijdens het redeneerproces. De resultaten lieten zien dat vier managers de juiste hypotheses noemden tegenover één senior. Daar tegenover stond dat twee managers en zes seniors wel een combinatie van alle relevante cues maakten, maar dat zij niet op de juiste hypotheses kwamen. De resterende proefpersonen, vier managers en vijf seniors, kwamen zelfs niet tot een goede combinatie van alle relevante cues en daardoor niet tot de juiste hypotheses.

In Tabel 2.2 zijn de expertisestudies naar verschillen in heuristieken en verschillen in het verloop van het redeneerproces samengevat. Voor dit proefschrift zijn een aantal bevindingen van bijzonder groot belang. Uit het onderzoek van Bouwman (1984) bleek bijvoorbeeld dat de ervaren accountants in tegenstelling tot de onervaren accountants een 'feeling' voor het bedrijfstype hadden ontwikkeld. Wat 'feeling' precies inhoudt werd niet duídelijk gemaakt. Biggs, Mock en Watkins (1988) constateerden dat de ervaren managers minder vaak naar de introductie van de casus keken dan de seniors, wat zou kunnen betekenen dat de ervaren managers, in tegenstelling tot de minder ervaren seniors, kennis in schemata hadden opgeslagen. Hoe zo'n schema ontstaat na het opdoen van ervaring en wat een schema inhoudt kwam in deze studies niet aan de orde. 
Tabel 2.2 Overzicht studies naar heuristieken \& het cognitieve redeneerproces

\begin{tabular}{|c|c|c|c|c|c|}
\hline Onderzoekers & Doel onderzoek & $\begin{array}{l}\text { Accountancy } \\
\text { taak }\end{array}$ & $\begin{array}{c}\text { Experimentele } \\
\text { taak }\end{array}$ & Proefpersonen & Resultaten \\
\hline $\begin{array}{l}\text { Frederick \& Labby } \\
\text { (1986) }\end{array}$ & $\begin{array}{l}\text { TRelatie fussen ervaring en } \\
\text { de heuristiek } \\
\text { 'representativiteit' }\end{array}$ & $\begin{array}{l}\text { Tinterme controle } \& \\
\text { Cijferbeoordeling }\end{array}$ & $\begin{array}{l}\text { Rangschilken van } \\
\text { kansschattingen }\end{array}$ & $\begin{array}{l}73 \text { beginnende } \\
\text { accountancystudenten: } \\
40 \text { MBA gevorderde } \\
\text { accountancystudenten: } \\
64 \text { accountants met 2,5-3.5 } \\
\text { jaar ervaring }\end{array}$ & $\begin{array}{l}\text { Onervaren accountants werden niet } \\
\text { verschillend beinvloed door } \\
\text { prototyplsche of inconsistente } \\
\text { fouten. } \\
\text { Experts werden wel verschillend } \\
\text { beinvloed door prototypische dan } \\
\text { wel inconsistente fouten. }\end{array}$ \\
\hline Bouwman (1978) & $\begin{array}{l}\text { Relatie tussen ervaring en } \\
\text { verschillen in strategletn. } \\
\text { beslissingsprocessen en } \\
\text { het informatiegebruik }\end{array}$ & Cijferbeoordeling & Hardopdenken & $\begin{array}{l}15 \text { onervaren studenten: } \\
3 \text { ervaren accountants }\end{array}$ & $\begin{array}{l}\text { Studenten gebruiken geen } \\
\text { specifieke strategle om de } \\
\text { informatie te evalueren. } \\
\text { Ervaren accountants gebruiken wel } \\
\text { een gerichte strategie en. } \\
\text { ontwikkelen een algemeen beeld } \\
\text { van het bedrijf. }\end{array}$ \\
\hline Bouwman (1984) & $\begin{array}{l}\text { Relatie tussen ervaring en } \\
\text { verschillen in strategieên, } \\
\text { beslissingsprocessen en } \\
\text { het informatiegebruik }\end{array}$ & Cifferbeoordeling & Hardopdenken & $\begin{array}{l}5 \text { onervaren studenten } \\
3 \text { ervaren accountants }\end{array}$ & $\begin{array}{l}\text { Studenten gaan op sequentiele wijze } \\
\text { door de informatie. } \\
\text { Ervaren accountants gaan aan de } \\
\text { hand van een fictieve checklist door } \\
\text { de informatie. Deze experts } \\
\text { ontwikkelen al in het begin een } \\
\text { 'feeling' voor het bedrilf. }\end{array}$ \\
\hline $\begin{array}{l}\text { Biggs, Mock \& } \\
\text { Watkins (1988) }\end{array}$ & $\begin{array}{l}\text { Relatic tussen ervaring en } \\
\text { verschillende stadia in } \\
\text { informatie-verwerking }\end{array}$ & Cijferbeoordeling & Hardopdenken & $\begin{array}{l}2 \text { managers met } 7 \text { jaar } \\
\text { ervaring: } \\
2 \text { seniors met } 3 \text { jaar } \\
\text { ervaring }\end{array}$ & $\begin{array}{l}\text { In de informatieverwervingsfase } \\
\text { maken de meer ervaren accountants } \\
\text { veel minder gebruik van het } \\
\text { introductiemateriaal dan de minder } \\
\text { ervaren accountants. } \\
\text { In de informatie-evaluatiefase } \\
\text { kwamen geen verschillen tussen de } \\
\text { ervaren en minder ervaren } \\
\text { accountants naar voren. } \\
\text { In de actie/keuzefase signaleerden } \\
\text { de managers fets meer inittele } \\
\text { problemen dan de seniors. } \\
\text { In de evaluatielase waren er geen } \\
\text { verschillen tussen de managers en } \\
\text { de seniors. }\end{array}$ \\
\hline
\end{tabular}




\begin{tabular}{|c|c|c|c|c|c|}
\hline \multicolumn{6}{|c|}{ Vervolg Tabel 2.2} \\
\hline Onderzoekers & Doel onderzoek & Accountancytaak & Experimentele taak & Proefpersonen & Resultaten \\
\hline $\begin{array}{l}\text { Libby \& Frederick } \\
\text { (1990) }\end{array}$ & $\begin{array}{l}\text { Retatie tussen ervaring en } \\
\text { genereren van fouten in } \\
\text { jaarrekening }\end{array}$ & Cifferbeoordeling & Causaal redeneren & $\begin{array}{l}70 \text { accountancystudenten; } \\
65 \text { stafleden met } 1 \text { Jaar } \\
\text { ervaring: } \\
61 \text { managers met } 5 \text { jaar } \\
\text { ervaring. }\end{array}$ & $\begin{array}{l}\text { Managers genereren een grotere } \\
\text { hoeveelheid plausibele fouten dan } \\
\text { de minder ervaren groepen. } \\
\text { Daarnaast genereerden de } \\
\text { managers significant meer fouten } \\
\text { die overeenkwamen met in de } \\
\text { praktijk frequenter voorkomende } \\
\text { fouten dan de studenten. Dit } \\
\text { verschil was niet te vinden tussen } \\
\text { managers en stafleden. } \\
\text { De studenten werden niet beinvloed } \\
\text { door het wel of niet aanbieden van } \\
\text { een fout, terwijl de assistenten en } \\
\text { managgers met name na een } \\
\text { atypische fout, fouten genereerden } \\
\text { die uit dezelfde waardenkringloop } \\
\text { kwamen. }\end{array}$ \\
\hline $\begin{array}{l}\text { Bedard \& Bigss } \\
\text { (1991) }\end{array}$ & $\begin{array}{l}\text { Reatle tussen ervaring en } \\
\text { patroonherkenning. } \\
\text { hypothese-generatie en } \\
\text { kwalitelt van de } \\
\text { besllssing. }\end{array}$ & Cijterbeoordeling & Hardopdenken & $\begin{array}{l}\text { I1 seniors: } \\
10 \text { managers }\end{array}$ & $\begin{array}{l}5 \text { managers en } 1 \text { senior } \\
\text { genereerden de juiste hypotheses. } \\
2 \text { managers en } 6 \text { seniors maakcten } \\
\text { wel een combinatie van alle } \\
\text { relevante cues, maar zij } \\
\text { genereerden niet de juiste. } \\
\text { hypotheses. } \\
4 \text { managers en } 5 \text { seniors kwamen } \\
\text { zelfs niet tot een goede cornbinatie } \\
\text { van alle relevante cues. }\end{array}$ \\
\hline
\end{tabular}




\section{Studies naar kennis en kennisstructuur}

Een van de eerste onderzoekers die studie heeft verricht naar de cognitieve effecten van ervaring was De Groot (1946, 1965). De Groot onderzocht de denk- en geheugenprocessen van schakers. In deze experimenten liet hij vler proefpersonen hardop denken terwljl ze een zet overwogen: een grootmeester, een meester, een plaatselijk schaakkampioen en een beginner. Resultaten gaven aan dat de ervaren grootmeester en de minder ervaren spelers voornamelijk verschilden in de kwaliteit van de zetten die ze deden. Naast. het hardopdenken vroeg de Groot zijn proefpersonen aan een geheugentaak mee te werken. Dit hleld in dat de proefpersonen schaakstellingen, na deze enkele seconden te hebben bestudeerd, moesten reproduceren. De resultaten lieten zien dat de grootmeester en de meester zich de schaakposities perfect konden herinneren in tegenstelling tot de twee minder ervaren proefpersonen.

Begin jaren tachtig volgden vergelijkbare studies in andere domeinen, zoals: de natuurkunde (Chi, Feltovich \& Glaser, 1981; Larkin, Mcdermott, Simon \& Simon, 1980); de geneeskunde (Boshuizen \& Claessen, 1981; Norman, Jacoby, Feightner \& Campbell, 1979); de politicologie (Voss, Tyler \& Yengo, 1983) en programmeren (Adelson, 1981). In deze onderzoeken werd een aantal consistente resultaten gevonden (ChI \& Glaser, 1988; Erlcsson \& Smith, 1991; Glaser, 1986):

- Experts bezitten meer domeinkennis dan niet-experts

* Domeinkennis van experts is beter georganiseerd dan domeinkennis van niet-experts

- Experts zijn sneller dan niet-experts

- Experts herinneren zich meer dan niet-experts ${ }^{11}$

- Experts maken meer inferenties dan niet-experts ${ }^{12}$

- Experts komen tot betere oplossingen dan niet-experts

Een cognitief model dat bovengenoemde bevindingen grotendeels kan verklaren is het model waarbij kennis als een conceptueel kennisnetwerk of 'semantisch netwerk' wordt gerepresenteerd (Collins \&

\footnotetext{
11 In het medisch domein geldt dit niet voor de co-assistenten. Deze hebben minder ervaring dan ervaren artsen. maar herinneren zich meer van een casus dan de ervaren, artsen. tenminste als voldoende bestuderingstjd wordt gegeven (Schmidt \& Boshuizen, 1993).

12 Inferenties zijn correcte conciusies en interpretaties.
} 
Quillian, 1969). Zo'n conceptueel kennisnetwerk bestaat uit concepten die aan elkaar verbonden zijn door 'links'. De concepten geven daarbij de eigenschappen of kenmerken van een begrip of idee weer en de 'links' geven de relatie aan tussen de begrippen of ideeên. Naarmate begrippen vaker met elkaar in verband worden gebracht, zullen de 'links' tussen de concepten in het netwerk sterker worden. In Figuur 2.1 wordt een voorbeeld van een conceptueel kennisnetwerk gegeven. De dikte van de lijnen geeft de sterkte van het verband tussen de concepten aan. In het netwerk in Figuur 2.1 heeft het concept 'solvabilliteit' bijvoorbeeld een sterke relatie met de concepten 'totale schulden' en 'totale activa'. De relatie tussen 'liquiditeit' en 'solvabiliteit' is minder sterk, wat wil zeggen dat die concepten minder vaak aan elkaar zijn gerelateerd.

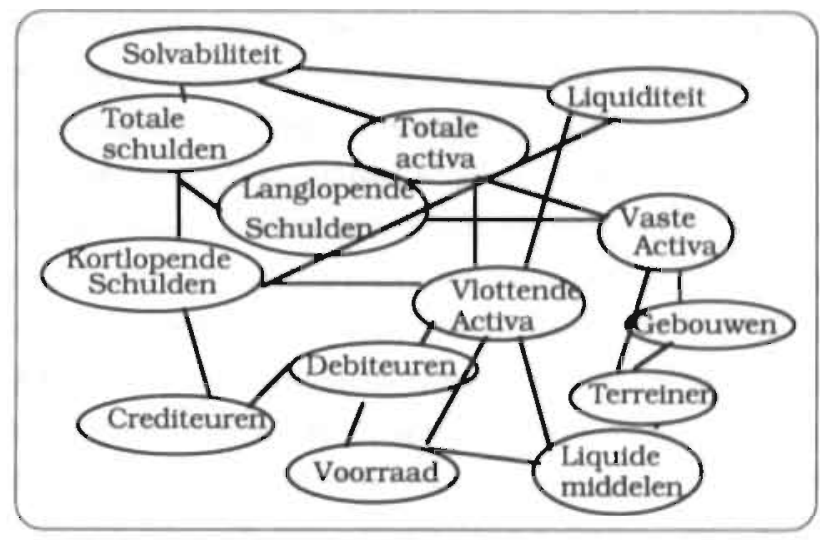

Figuur 2.1 Voorbeeld van een financieel kennisnetwerk

Men veronderstelt nu dat bij het begrijpen van de buitenwereld, relevante concepten worden geactiveerd die helpen de binnenkomende informatie te interpreteren. Tegelijkertijd worden gerelateerde concepten in het netwerk geactiveerd. Dit wordt spreidende activatie genoemd (Collins \& Loftus, 1975). Naarmate de 'links" tussen de concepten sterker zijn, neemt de kans dat een gerelateerd concept eveneens wordt geactiveerd, toe.

$\mathrm{Nu}$ is in Figuur 2.1 een conceptueel kennisnetwerk weergegeven waarbij is 'ingezoomd' op een financieel netwerk. Men zou zich ook voor kunnen stellen dat er van ieder vak dat een student bestudeerd heeft een afzonderlijk netwerk is gevormd (Boshuizen, 1995; Feltovich \& Barrows, 1984). Naarmate een student het accountancycurriculum. 
verder doorloopt, zal hij steeds meer kennis opdoen en zullen de afzonderilike kennisnetwerken meer en meer concepten gaan bevatten. Daamaast kan verwacht worden dat een gevorderde student kennisnetwerken krijgt waarin het aantal verbanden tussen de concepten toeneemt (Chi, Feltovich \& Glaser, 1981; Feltovich, 1981; Voss. Greene, Post \& Penner, 1984). Naarmate deze gevorderde studenten meer accountancyvakken gevolgd hebben en bovendien te maken krijgen met integratie van vakken zullen zij niet alleen binnen de conceptuele netwerken meer verbanden leggen, maar ook tussen de conceptuele netwerken (Boshuizen, 1995). Verwacht kan worden dat vierdejaars accountancystudenten, die nog weinig met situaties te maken hebben gehad waarin geïntegreerde kennis uit verschillende accountancyvakken gebruikt dient te worden, enigszins moeite zullen hebben om verbanden te leggen tussen de concepten uit die verschillende vakken. Daarentegen zullen de postdoctoraal studenten die al enige praktijkervaring hebben opgedaan waarschijnlijk gemakkelijker verbanden leggen, omdat ze in de praktijk situaties zijn tegengekomen die, om begrepen te kunnen worden, integratie van kennis uit verschillende basisvakken noodzakelijk maakten. Van deze laatste groep wordt dan ook. verwacht dat ze niet. alleen meer 'links' binnen de netwerken zullen bezitten, maar dat er ook meer 'links' tussen de verschillende kennisnetwerken zullen zijn dan bij de onervaren vierdejaars studenten. Experts zullen een nog uitgebreider en complexer conceptueel netwerk hebben dan de ervaren postdoctoraal studenten. Dat will zeggen dat de netwerken van experts aanzienlijk. meer concepten en relaties bevatten dan de netwerken van minder ervaren personen (Feltovich, 1981; Voss. Greene, Post \& Penner, 1984).

Niet alleen hebben experts uitgebreidere en complexere netwerken. resultaten uit verschillende studies geven ook aan, dat experts hun kennis beter hebben gestructureerd dan beginners \{Adelson, 1981; Chi, Feltovich \& Glaser, 1981; Lesgold, Rubinson, Feltovich, Glaser, Klopfer \& Wang, 1988). Adelson (1981) toonde aan dat de programmeerkennis van ervaren programmeurs naar de functie van het computerprogramma was georganiseerd, terwijl beginners hun kennis op basis van de syntax. hadden georganiseerd. Volgens Adelson gaven deze uitkomsten aan dat de kennisorganisatie van experts een hiërarchische structuur had, terwijl de kennis van beginners nauwelijks gestructureerd was. Resultaten uit een onderzoek van Chi, Feltovich en Glaser (1981) lieten eveneens zien dat de domeinkennis van experts beter was gestructureerd dan de kennis van beginners. Uit de studie van Chi et al. bleek dat 
experts hun domeinkennis hadden georganiseerd naar 'hogere' natuurkundewetten, terwijl de domeinkennis van beginners aan de hand van oppervlakkige kenmerken was georganiseerd.

Deze betere structuur van de kennisorganisatie bij experts zou als gevolg moeten hebben dat experts sneller een representatie kunnen vormen van een probleem uit hun domein dan beginners. Immers, experts kunnen vanwege die betere kennisstructuur veel sneller de juiste concepten activeren dan beginners. Bevindingen uit onderzoek van Boshuizen (1989), Muzzin, Norman, Jacoby, Feightner, Tugwell en Gyatt (1982) en Norman, Brooks en Allen (1989) hebben Inderdaad aangetoond dat ervaren artsen minder tijd nodig hebben om een representatie te vormen van een medisch probleem dan onervaren studenten.

Spilich, Vesonder, Chiesi en Voss (1979) en Chiesi, Spilich en Voss (1979) toonden daarnaast aan dat personen die veel weten van een bepaald onderwerp, veel beter in staat zijn nieuwe relevante informatie te onthouden dan personen die minder weten van dat onderwerp. Personen die veel wisten van honkbal konden zich veel meer herinneren van een honkbalwedstrijd dan personen die weinig wisten van honkbal. Wanneer aanwezige kennis inderdaad wordt gebruikt bij het begrijpen van informatie, dan zullen experts, van wie wordt verondersteld dat ze meer domeinkennis bezitten dan beginners, zich meer moeten herinneren van informatie dan beginners. Immers experts hebben een. uitgebreider kennisnetwerk dan beginners, waardoor experts meer mogelijkheden hebben om nieuwe relevante informatie te koppelen aan bestaande concepten dan beginners. In verschillende domeinen is inderdaad aangetoond dat het terughalen van informatie (de 'recall') van experts beter was dan de 'recall' van niet-experts (Adelson, 1981; Chase \& Simon, 1973; De Groot, 1946, 1965; Patel \& Medley-Mark, 1986).

Experts blijken zich niet alleen meer letterlijke gegevens te kunnen herinneren van een casus, hun herinnering, 'recall', bevat ook meer inferenties dan de 'recall' van beginners (Boshuizen, 1989; Coughlin \& Patel, 1987). Met inferenties wordt bedoeld dat er in de 'recall' conclusies en interpretaties worden geproduceerd die niet letterlijk in de aangeboden informatie stonden. Een theoretische verklaring voor de bevinding dat experts meer inferenties in de 'recall' produceren dan beginners kan worden afgeleid uit het tekstverwerkingsmodel van Van Dijk en Kintsch (1983). In dit model beschrijven Van Dijk en Kintsch 
hoe kennis en informatie geīntegreerd worden tijdens het doornemen van een tekst. Deze onderzoekers stellen dat personen, tijdens het doornemen van een tekst, een interne representatie vormen die zowel semantische kenmerken van de aangeboden informatie (textbase), als kennis die is opgedaan in eerdere situaties (situatiemodel) zal bevatten. Volgens Van Dijk en Kintsch zullen experts bij het doornemen van relevante informatie een representatie vormen die grotendeels gebaseerd is op het situatiemodel, omdat zij een uitgebreid kennisnetwerk hebben. Een gevolg van zo'n op kennis gebaseerde representatie is dat er veel inferenties in zullen voorkomen (Van Dijk en Kintsch, 1983). Beginners daarentegen nemen volgens Van Dijk en Kintsch slechts de 'textbase' als basis voor een representatie. Zij bezitten immers aanzienlijk minder domeinkennis en zijn daardoor veel minder goed in staat om kennis en informatie te integreren. In de representaties van beginners zullen volgens Van Dijk en Kintsch dan ook nauwelijks inferenties voorkomen. Een manier om te achterhalen of experts en beginners verschillen in het aantal inferenties is door hun achteraf te vragen wat ze zich nog kunnen herinneren van een eerder aangeboden tekst. Van Dijk en Kintsch nemen aan dat verschillen tussen representaties van experts en beginners in de 'recail' naar voren moeten komen. De 'recall' is volgens hun namelijk een afspiegeling van de eerder gevormde representatie. Resultaten uit onderzoeken van Boshuizen (1989), Coughlin en Patel (1987) en Walker (1987) lieten zien dat experts en beginners inderdaad significant verschilden in het aantal inferenties dat ze produceerden in de 'recall'. In deze studies werd duidelijk een rechtlijnig verband tussen expertise-niveau en het aantal geproduceerde inferenties gevonden.

Een gevolg van een uitgebreider, complexer en beter gestructureerd kennisnetwerk zou moeten zijn dat problemen niet alleen beter worden begrepen maar ook beter worden opgelost. Inderdaad hebben resultaten uit verschillende studies aangetoond dat experts hun conceptuele kennis beter kunnen toepassen op probleemsituaties binnen hun domein dan beginners. In het medische domein werden resultaten gevonden waaruit bleek dat ervaren artsen consistent beter waren in het oplossen van een diagnostisch probleem dan studenten (Boshuizen, 1989; Patel \& Groen, 1986). In de sociale wetenschappen hebben Voss, Tyler en Yengo (1983) een onderzoek uitgevoerd waaruit eveneens naar voren kwam dat experts hun kennis beter wisten toe te passen op een probleem. In het onderzoek van Voss. Tyler en Yengo dienden proefpersonen een politiek probleem over de landbouw in de Sovjet Unie op 
te lossen. Bij het oplossen van dit probleem bleken experts zich te beperken tot de specifieke situatie en spitsten ze hun oplossing toe op de Sovjet Unie. Beginners daarentegen, droegen oplossingen aan die voor ieder landbouwprobleem zouden kunnen gelden. $\mathrm{Zij}$ richtten zich meer op de landbouw in het algemeen en minder specifiek op die van de Sovjet Unie.

Resultaten uit verschillende domeinen hebben dus aangetoond dat expertise-niveau positief samenhangt met kennis en kennisstructuur. Ook in het accountancydomein zijn studies uitgevoerd naar de relatie tussen expertise-niveau en kennis en kennisstructuur. Deze zullen in de volgende paragraaf aan de orde komen.

\section{Studles naar kennis en kennisstructuur bij accountants}

De eerste onderzoeker in het accountancydomein die belangstelling had voor de organisatie van kennis was Weber (1980). Hij richtte zich daarbij op een specifiek onderdeel van de accountancy, namelijk op de EDP-accountancy (EDP staat voor Electronic Data Processing; hierbij is de controle met name gericht op geautomatiseerde systemen). Aan het onderzoek namen 67 accountants deel wier ervaring met EDPaccountancy varieerde van nul tot drie jaar. Daarnaast namen 96 studenten deel aan het onderzoek. Zij fungeerden als controlegroep. Het materiaal bevatte een lifst met computer-controleprocedures zoals: 'veranderingen in het systeem en het computerprogramma behoeven een goedkeuring van hogerhand' of 'tijd en datum dienen op alle rapporten te zijn afgedrukt. Deze controle-procedures werden opgedeeld in vijf categorieên: 1) management en organisatie; 2) data-voorbereiding; 3) input; 4) verwerking en 5) output. Voordat het onderzoek begon werd aan de proefpersonen uitgelegd wat de gehele procedure ging inhouden. Daarna werden de computer controle procedures 'at random' voorgelezen. Meteen na het voorlezen werd aan de proefpersonen gevraagd om de computer-controleprocedures op te schrijven. Terwijl de proefpersonen de procedures aan het opschrijven waren gaf de experimentator op bepaalde tijdstippen aan dat de proefpersonen een streep onder de laatste procedure moesten zetten. Dit werd een paar keer herhaald, totdat de proefpersonen alles wat ze zich nog konden herinneren hadden opgeschreven. De resultaten van het onderzoek gaven aan dat 
de ervaren accountants, zoals Weber verwachtte, meer onthielden van de controleprocedures dan de studenten. Bovendien bevatte de 'recalls' van de studenten meer irrelevante gegevens (gegevens die niet in het stimulusmateriaal voorkwamen). Een volgend resultaat liet zien dat de ervaren accountants meer clusters in hun 'recall' weergaven dan de studenten. Volgens Weber kon men hieruit concluderen dat de accountants een beter georganiseerd kennisnetwerk bezaten dan de studenten.

In 1990 onderzocht Moeckel of ervaren accountants en minder ervaren accountants verschillen vertoonden in het maken van geheugenfouten. Zij veronderstelde dat ervaren accountants meer kennis in schema's ${ }^{13}$ zouden hebben opgeslagen en daardoor andere geheugenfouten zouden maken dan minder ervaren accountants. Aan het onderzoek deden vier verschillende groepen mee: assistenten, stafleden, senioren en managers/partners. Het experiment nam twee dagen in beslag. Op de eerste dag kregen de proefpersonen de taak om een aantal 'work papers' te checken. In zo'n 'work paper' zaten acht combinaties van items die voor een controle tegengestelde bewijzen zouden opleveren. Op de tweede dag kregen de proefpersonen een herkenningstest, waarbij ze dienden aan te geven of een item expliciet In de 'work paper' van de eerste dag gestaan had of goed samengevat was of nieuw en niet goed samengevat was. Moeckel was bij de herkenningstaak geïnteresseerd in drie types herkenningsfouten: reconstructiefouten, samenvattingsfouten en expliciete herkenningsfouten. Reconstructiefouten werden gedeînieerd als fouten waarbij 'defaultwaarden' van een bestaand schema onterecht ingevuld werden. Samenvattingsfouten werden geteld als de proefpersonen een foute samenvatting als goed bestempelden. Expliciete herkennings-fouten werden geïdentificeerd als de proefpersonen het woord 'expliciet' gebruikten bij het fout herkennen van items. De resultaten gaven aan dat managers de gegevens uit een 'working paper' vaker reconstrueerden dan de assistenten. De assistenten daarentegen maakten meer expliciete geheugenfouten. Moeckel was niet alleen geỉnteresseerd in verschillende types herkenningsfouten, maar ook in integratiefouten. De onervaren assistenten bleken meer moeite te hebben om de acht

13 Een schema is een semantische representatie van generieke kennis over gebeurtenissen. scenario's, acties en objecten (Anderson, 1995). Andere aanduidingen in de literatuur zijn: frames (Minsky, 1975) en scripts (Schank \& Abelson, 1977). 
combinaties van items uit de 'working paper-items' te integreren dan de meer ervaren accountants.

Frederick (1991) onderzocht de relatie tussen ervaring en de organisatie van kennis betreffende de interne controle. Aan het onderzoek deden twee groepen proefpersonen mee: onervaren doctoraal studenten en accountants met minstens drie en gemiddeld vier jaren ervaring. Proefpersonen hadden de taak om na bestudering van de interne controle procedures van de inkoop- en uitgave waardenkringlopen van een industrieel bedrijf datgene te noteren wat ze zich nog konden herinneren van deze interne controleprocedures (recall). In het onderzoek konden de proefpersonen aan één van de twee stimuluscondities worden toegewezen: de 'taxonomische' of de 'schematische' conditie. De taxonomische stimulusconditie hield in dat de interne controleprocedures werden ingedeeld in categorieên op grond van klasse-eigenschappen. Bij interne controleprocedures waren dat categorieën zoals: autorisatie, validiteit van transactie, functie-scheiding, volledigheid van transactie en juistheid van opslaan. In de schematische stimulusconditie werd een organisatie aangeboden die bestond uit concepten die overeenkwamen wat betreft ruimtelijke en temporele kenmerken. Bijvoorbeeld de interne controle-aspecten: verkoop, ontvangsten en te betalen rekeningen. Frederick verwachtte dat naarmate een accountant meer ervaring had, hij zijn kennis over interne controleprocedures meer naar ruimtelijke en temporele kenmerken zou organiseren, terwijl de minder ervaren personen de interne controle waarschijniljk op taxonomische wijze georganiseerd zouden hebben. De resultaten lieten zien dat ervaren accountants, zoals verwacht, meer inteme controle-aspecten onthielden dan de minder ervaren accountants. Verder was er een significante interactie tussen ervaring en type stimulusorganisatie. Dit betekende dat ervaren accountants in de 'free recall' meer onthielden van materiaal dat volgens een schematische structuur was georganiseerd dan materiaal dat een taxonomische organisatiestructuur had. Bij de onervaren studenten maakte de structuur van de informatie niet uit voor de hoeveelheid 'recall'. Daarnaast clusterden de ervaren accountants de 'recall' meer dan de onervaren studenten. Beide groepen clusterden hun 'recall' meer wanneer ze de stimulus uit de schematische conditie aangeboden hadden gekregen.

Choo en Trotman (1991) deden een onderzoek waarin de relatie tussen kennisstructuur en oordelen van ervaren en onervaren 
accountants centraal stond. De context waarin het experiment werd afgenomen was een faillissementsprobleem van een bedrijf. Twee groepen proefpersonen bestaande uit accountants met gemiddeld 4,4 jaar ervaring en assistenten met minder dan zes maanden ervaring namen deel aan dit onderzoek. Een van de hypotheses hield in, dat ervaren accountants meer atypische ${ }^{14}$ dan typische items zouden onthouden. Bij de minder ervaren accountants zou het type item niet uitmaken, omdat verondersteld werd dat zij, vanwege de geringe ervaring, te weinig kennis bezaten om typische dan wel atypische eigenschappen van bedrijven te kunnen onderscheiden. Verder was de verwachting dat er in de 'recall' groeperingen (clusters) gevornd zouden worden op grond van typische dan well atypische beweringen. Een andere voorspelling betrof de relatie tussen hoeveelheid 'recall' en uiteindelijke beslissingen die accountants zouden nemen. De verwachting was dat iemand die meer onthield van een casus beter zou kunnen voorspellen of een bedrijf failliet zou gaan dan lemand die weinig onthield. De procedure van het onderzoek. was als volgt: proefpersonen kregen de opdracht een beschrijving van een bedrijf te lezen met de mededeling dat de vennoot had gesuggereerd dat het bedrijf mogelijk een faillissementsprobleem had. De proefpersonen waren op de hoogte van het feit dat ze na het lezen eventueel vragen dienden te beantwoorden. Proefpersonen kregen vijf minuten de tijd om te lezen, waarna ze gedurende 20 minuten een niet aan de accountantstaak gerelateerde taak te doen kregen. Daarna werd hun gevraagd te noteren wat ze zich nog konden herinneren van het bedrijf (free recall). De volgende opdracht was om van tien items, die niet letterlijk in de beschrijving van het bedrijf hadden gestaan, aan te geven hoe waarschijnlijk het was dat die items voor dit bedrijf opgingen. De heift van die items bestond uit beweringen die door ervaren accountants beoordeeld waren als een typische eigenschap voor een bedrijf met faillissementsproblemen en de andere helft bestond uit items die als atypisch beoordeeld waren voor een bedrijf met faillissements-problemen. In de laatste taak werden de proefpersonen gevraagd aan te geven of zij dachten dat het bedrijf binnen één jaar failliet zou zijn. De resultaten lieten zien dat de ervaren accountants zich zoals verwacht meer herinnerden dan de minder ervaren accountants. Dat significante verschil werd met name

\footnotetext{
14 Typiciteit wordt door Choo en Trotman gedefinieerd als waarschijnlijkheid. Dus, als lets typisch is voor een failliet gaand bedrijf, dan betekent dat volgens Choo \& Trotman dat het zeer waarschijnlijk is dat dat gebeurt.
} 
veroorzaakt door de atypische items. Daarnaast was er in de recall van de onervaren accountants geen verschil te vinden tussen typische en atypische items. Verder gaven de resultaten aan dat er in de 'recall' clusters gevormd werden op grond van typische dan wel atypische beweringen. De ervaren groep clusterde significant vaker dan de minder ervaren groep. De resultaten van de taak waarbij proefpersonen gevraagd waren aan te geven welke mate van waarschijnlijkheid een typische of atypische bewering had lieten zien dat beide groepen vaker aangaven dat typische beweringen waarschijnlijker waren voor dit bedrijf dan atypische beweringen. Verder bleken ervaren accountants atypische beweringen vaker waarschijnlijk te vinden dan de onervaren accountants. De laatste hypothese waarin een directe relatie tussen hoeveelheid 'recall' en de voorspelling van het faillissement was voorspeld leidde tot een teleurstellend resultaat. Wel was er sprake van een indirecte relatie, dat wil zeggen bij de ervaren accountants was er een significante correlatie tussen 'recall', het aangeven van waarschijnlijkheden en de voorspelling van het faillissement. Bij de onervaren accountants bleek deze indirecte relatie niet significant te zijn. Choo en Trotman (1991) gaven in de discussie aan dat er meer onderzoek nodig is om duidelijkheid te krijgen over de relatie tussen kennis en oordeel

Rennie (1991) onderzocht of ervaren accountants hun kennis over het interne controlesysteem in het Lange Termijn Geheugen representeren als een mentaal model. Onder mentaal model verstaat Rennie een representatle van een abstracte categorie uit de werkelijkheid waarin een sequentiële ordening $\mathrm{zit}^{15}$. Aan het onderzoek deden twee groepen proefpersonen mee: een groep accountants met gemiddeld 6,6 jaren ervaring die manager waren en een groep onervaren accountancystudenten. Rennie verwachtte dat de kennis over de interne controleprocedures van ervaren accountants goed georganiseerd was, terwijl de onervaren studenten hun kennis waarschijnlijk minder goed georganiseerd zouden hebben. Haar redenering was dat ervaren accountants zich dan meer kunnen herinneren van een verhaal over de interne controle dan de studenten. Rennie voorspelde eveneens dat de ervaren accountants zich minder zullen herinneren van irrelevante zaken dan de studenten. Een laatste hypothese was dat kennis volgens

${ }^{15}$ Rennies opvattingen over een mentaal model komen ongeveer overeen met een schema alleen is hier sprake van een sequenttêle ordening. Dit zou volgens andere onderzoekers een script genoemd worden (Schank \& Abelson, 1977). 
een sequentieel mentaal model zou worden opgeslagen. Dit zou betekenen dat ervaren accountants zich, ondanks het lezen van een door elkaar gehusselde tekst, de tekst in. een 'normale' ordening zullen herinneren. De procedure van het experiment was als volgt: de proefpersonen lazen twee teksten, waarvan de eerste niet relevant was voor dit experiment en de tweede wel. De inhoud van de tweede tekst bestond uit een verhandeling over een intern controlesysteem waarbij de volgorde van de gegevens door elkaar was gehusseld. Na het lezen van de twee teksten werd de proefpersonen gevraagd aan te geven in hoeverre het interne controlesysteem uit het tweede verhaal fouten zou kunnen voorkómen. Nadat de proefpersonen dat hadden ingevuld kregen ze cen aantal afleidende taken te doen. Pas daarna werd de opdracht gegeven om alles wat ze zich van het tweede interne controle verhaal herinnerden op te schrijven. Deze studie liet zien dat ervaren managers zich inderdaad meer herinnerden dan studenten. Echter, wat Rennie niet had voorspeld, was dat ervaren managers niet minder vaak het irrelevante item onthielden dan de studenten. De laatste hypothese, dat de 'normale' structuur van het verhaal door ervaren accountants in de 'recall' wordt teruggegeven werd wel bevestigd. Volgens Rennie duidde dit erop dat ervaren accountants een sequentieel mentaal model hadden gevormd van het interne controlesysteem van de verkoop- en ontvangst mutatiestroom.

Tubbs (1992) deed onderzoek naar het effect van ervaring op de organisatie en hoeveelheid kennis van accountants. Hierbif ging het met name om de kennis van onregelmatigheden in de mutatiestroom verkoop-ontvangsten-kas van een handelsbedrijf. Verder was Tubbs geïnteresseerd in hoeverre ervaring in verband stond met het kunnen toepassen van deze kennis over onregelmatigheden. In totaal deden er 95 proefpersonen aan dit onderzoek mee: 23 accountancystudenten zonder ervaring, 29 juniors met een mediaan van één jaar ervaring, 21 seniors met een mediaan van drie jaar ervaring en 22 managers met een mediaan van 6,3 jaar ervaring. De proefpersonen kregen twee taken: ten eerste moesten ze gedurende 15 minuten alle mogelijke onregelmatigheden van de mutatiestroom verkoop-ontvangsten-kas van een handelsbedrijf opschrijven. Ten tweede kregen de proefpersonen een lijst aangeboden waarop acht onregelmatigheden stonden. Zij moesten hiervan de kans schatten dat deze onregelmatigheden zouden kunnen voorkomen in een handelsbedrijf of in een industrieel bedrijf. Daarna werd hun verteld dat er een fout was gesignaleerd in dat bedrijf en 
kregen de proefpersonen de mogelijkheid hun eerder geschatte kansen aan te passen. Resultaten lieten zien dat de ervaren managers significant meer onregelmatigheden noemden dan de onervaren studenten en assistenten. In het aantal gemelde onregelmatigheden was geen verschil te vinden tussen de managers en seniors. Verder noemden studenten en assistenten significant meer incorrecte onregelmatigheden dan ervaren managers. Er was geen significant verschil tussen studenten, assistenten en seniors. Een volgende hypothese van Tubbs betrof het aantal atypische ${ }^{16}$ onregelmatigheden dat werd beschreven. Tubbs verwachtte dat naarmate ervaring toenam de hoeveelheid atypische onregelmatigheden ook zou toenemen. De data bevestigden deze hypothese, alle groepen verschilden significant van elkaar: de managers noemden de meeste atypische onregelmatigheden en de studenten noemden de minste atypische onregelmatigheden. De laatste bevinding was dat studenten en assistenten aanzienlijk minder goed konden aangeven hoe de onregelmatigheden voorkómen kondlen worden. Dit betekende volgens Tubbs dat de minder ervaren proefpersonen minder goed begrepen wat oorzaak en gevolg waren van de gepresenteerde onregelmatigheden.

Christ (1993) onderzocht de relatie tussen ervaring en de representatie van de planning in de eerste fase van het accountantsproces. Er namen drie groepen accountants deel aan dit onderzoek: 82 juniors met één jaar ervaring, 55 seniors met gemiddeld 3,5 jaar ervaring en 74 managers/partners met gemiddeld 9,5 jaar ervaring. Het materiaal bestond uit een casus van ongeveer 20 bladzijden, waarin onder andere een gedetailleerde beschrijving van het bedrijf gegeven werd, een organisatieschema, verlies-en-winst rekening, een balans en een interne controleprocedurelijst voor 'opbrengsten'. De procedure van het experiment was de volgende: eerst moesten de proefpersonen planningsoordelen geven ten aanzien van de mutatiestroom 'opbrengsten'. Daarna werd een persoonlijke vragenlijst aangeboden om de proefpersonen af te leiden van de eerste taak en als laatste werd aan de proefpersonen gevraagd wat ze zich nog konden herinneren van het casusmateriaal. Naar aanleiding van expertisestudies in andere domeinen verwachtte Christ (1993) dat de meer ervaren accountants meer kennis (en daardoor meer 'recall') zouden hebben dan de minder

16 Onder typiciteit verstaat Tubbs de mate waarin een object representatief is voor een categorie. 
ervaren accountants. Verder voorspelde ze dat er een positief verband zou zijn tussen ervaring en het aantal relaties tussen concepten in de planningsrepresentatie. Als laatste resultaat verwachtte Christ dat de planningsrepresentaties van ervaren accountants meer abstracte kennis (samenvattingen en inferentles) zouden bevatten. De resultaten lieten zien dat de ervaren managers/partners en de seniors significant meer hadden onthouden van de casus dan de minder ervaren juniors. Het verschil tussen de managers/partners en seniors was echter niet significant. Ook ten aanzien van het aantal relaties in de 'recall' bleek alleen een significant verschil te bestaan tussen managers/partners en juniors. Wat betreft de abstracte kennis (samenvattingen, inferenties) werd een signiticant verschil gevonden tussen alle drie groepen. Naast deze resultaten heeft Christ de recall inhoudelijk gescoord. $\mathbf{Z i j}$ lette; daarbij op verschillende categorieën: 1) informatie over het bedrijf. 2) financięle informatie, 3) informatie over de interne controle en 4) overige informatie zoals 'voorraad is verouderd' of 'geen opmerking over de integriteit van het management'. Ten aanzien van deze inhoudelijke opmerkingen bleek een significant verschil tussen de groepen te bestaan: informatie over het bedrijf werd minder genoemd naarmate de accountants meer ervaring hadden: juntors herinnerden zich significant minder financiële informatle dan de meer ervaren groepen; managers/pariners herinnerden zich meer informatie die in de categorie overig hoorden dan de andere twee groepen.

In een onderzoek van Frederick, Heiman-Hoffman en Libby (1994) werd een studie uitgevoerd om te achterhalen wat de aard, ontwikkeling en organisatie van de kennis omtrent fouten in de financiële jaarrekening bij accountants is. Daarbij ging het Frederick et al. (1994) om twee zaken. Ten eerste wilden ze onderzoeken of er verschillen waren in de organisatie van het kennisbestand als ervaring toenam. Ten tweede wilden ze emplrisch aantonen dat de organisatie van kennis over fouten in de jaarrekening, net als kennis over fouten in de interne controle, georganiseerd zijn naar mutatiestroom respectievelijk controledoel (zie Frederick, 1991), Deelnemers aan het onderzoek waren managers met een mediaan van vijf jaar ervaring, assistenten met een mediaan van één jaar ervaring en accountancy studenten zonder ervaring. De procedure bestond uit een taak. waarin de deelnemers 35 fouten uit de jaarrekening moesten categoriseren. Er waren drie experimentele condities. In de eerste conditie, de vrije categorisatie, werden de proefpersonen geheel vrijgelaten in de keuze van het te gebruiken criterium. 
In de tweede conditie werd de proefpersonen verzocht te sorteren naar mutatiestroom zoals inkoop, voorraden en verkoop. In de derde conditie werd de proefpersonen gevraagd te sorteren naar controledoelen zoals 'juiste waardering' en 'juiste classificatie'. Alle proefpersonen moesten na het categoriseren een titel geven aan de stapels gesorteerde kaartjes. Resultaten lieten zien dat bij een vrije keuze van het criterium managers een voorkeur hadden om te categoriseren naar controledoel. De categorisatie van de assistenten bij de conditie 'vrije keuze' correleerde 0.73 met de categorisatie van de managers. De correlatie van de categorisatie van de assistenten met de categorisatie van de studenten was bij de conditie 'vrije keuze' 0.74. De categorisatie van managers en studenten correleerden 0.65 bij de conditie 'vrije keuze". Deze 'vrije keuze' leidde dus niet tot zeer grote verschillen tussen de verschillende groepen. Bij de opdracht 'sorteer naar waardekringloop' was er een correlatie van 0.87 tussen managers en assistenten. Dat hield in dat de managers en de assistenten vergelijkbare categorieěn hadden gemaakt. De categorieèn van de studenten correleerden slechts 0.45 met zowel de categorieèn van de managers als die van de assistenten. Een van de redenen voor deze lage correlatie was, dat de categorisatie van de studenten, bij de 'mutatiestroom-conditie' niet alleen 'mutatiestroom-categorieên' bevatte maar ook 'controledoelcategorieèn'. Bij de derde opdracht de 'controledoel-conditie' correleerden de categorieën van managers en assistenten 0.77 met elkaar. De correlatie tussen managers en studenten was 0.63 en die tussen assistenten en studenten 0.74. Uiteindelijk bleek dat zowel managers als assistenten er de voorkeur aan gaven om te categoriseren naar 'controledoel', terwijl de studenten geen duidelijke voorkeur hadden voor 'mutatiestroom' of 'controledoel'. Daarnaast bleek de conditie 'mutatiestroom' een verschil op te leveren tussen de gevormde categorieën van assistenten en managers enerzijds en studenten anderzijds. Volgens Frederick et al. (1994) bestonden er ook nog enige inhoudelijke verschillen tussen de categorieên van studenten, assistenten en managers. Zo bleek dat de categorieên van de studenten en assistenten meer overeenkwamen met studieboeken en accountancystandaards, terwijl de managers vaker categoriseerden op basis van controletests.

In deze studies is een aantal consistente resultaten verkregen (voor een overzicht zie Tabel 2.3). 
Tabel 2.3 Overzicht van studies naar kennis en kennisorganisatie

\begin{tabular}{|c|c|c|c|c|c|}
\hline Onderzoekers & Doel onderzoek & Accountancytaak & $\begin{array}{c}\text { Experimentele } \\
\text { taak }\end{array}$ & Proefpersonen & Resultaten \\
\hline Moeckel (1990) & $\begin{array}{l}\text { Relatie tussen ervaring en } \\
\text { geheugenfouten }\end{array}$ & $\begin{array}{l}\text { Controleren van } \\
\text { working papers' }\end{array}$ & Herkenningstaak & $\begin{array}{l}35 \text { assistenten: } \\
19 \text { stafleden; } \\
15 \text { seniors; } \\
16 \text { managers/partners }\end{array}$ & $\begin{array}{l}\text { Managers maakten vaker } \\
\text { reconstructiefouten in de } \\
\text { herkenningstaak dan assistenten. } \\
\text { Assistenten maakten meer } \\
\text { letterlijke herkenningsfouten. } \\
\text { Assistenten bleken meer moeite te } \\
\text { hebben om de mogelijke } \\
\text { combinaties van items te maken } \\
\text { dan de meer ervaren accountants. }\end{array}$ \\
\hline Frederick (1991) & $\begin{array}{l}\text { Relatie tussen ervaring en } \\
\text { de organisatie en } \\
\text { hoeveelheid van kennis } \\
\text { betreffende interne } \\
\text { controleprocedures }\end{array}$ & Interne controle & Herinneringstaak. & $\begin{array}{l}97 \text { accountancystudenten: } \\
113 \text { accountants met } \\
\text { gemiddeld vier jaar } \\
\text { ervaring }\end{array}$ & $\begin{array}{l}\text { Ervaren accountants herinnerden } \\
\text { significant meer interne controle } \\
\text { procedures dan studenten. } \\
\text { Ervaren accountants herinnerden } \\
\text { zich meer na een schematische } \\
\text { organisatie dan na een } \\
\text { taxonomische organisatie. } \\
\text { Novieten herinnerden zich van } \\
\text { beide categorieên evenveel. } \\
\text { Ervaren accountants clusterden } \\
\text { de interne controle procedures } \\
\text { meer dan studenten. }\end{array}$ \\
\hline $\begin{array}{l}\text { Choo \& Trotman } \\
\text { (1991) }\end{array}$ & $\begin{array}{l}\text { Relatic tussen ervaring. } \\
\text { kennisstructuur en } \\
\text { beslissing }\end{array}$ & $\begin{array}{l}\text { Faillissements. } \\
\text { probleem }\end{array}$ & $\begin{array}{l}\text { Herinneringstaak } \\
\text { Waarschijnlijk- } \\
\text { heidsschatting } \\
\text { Voorspelling van } \\
\text { faillisement }\end{array}$ & $\begin{array}{l}\text { assistenten met minder dan } \\
\text { zes maanden ervaring: } \\
\text { senior } \mathrm{s} \text { met een } \\
\text { gemiddelde van } 4,4 \text { jaar } \\
\text { ervaring }\end{array}$ & $\begin{array}{l}\text { Ervaren accountants herinnerden } \\
\text { zich meer dan assistenten. } \\
\text { Ervaren accountants herinnerden } \\
\text { zich met name meer atypische } \\
\text { items, terwijl onervaren } \\
\text { accountants geen verschil } \\
\text { vertoonden tussen typische en } \\
\text { atypische items. De ervaren groep } \\
\text { clusterde significant vaker dan } \\
\text { minder ervaren groep. } \\
\text { Beide groepen gaven vaker aan } \\
\text { dat typische beweringen } \\
\text { waarschijnlijker waren voor dit } \\
\text { bedrijf. } \\
\text { Ervaren accountants bleken } \\
\text { atypische beweringen vaker } \\
\text { waarschijnlijk te vinden dan de } \\
\text { onervaren accountants. } \\
\text { Er bleek een indirecte relatie te } \\
\text { bestaan tussen ervaring. 'recall'. } \\
\text { waarschijnlijkheid en } \\
\text { voorspelling. }\end{array}$ \\
\hline
\end{tabular}




\begin{tabular}{|c|c|c|c|c|c|}
\hline \multicolumn{6}{|c|}{ Vervolg Tabel 2.3} \\
\hline Onderzoekers & Doel onderzoek & Accountancytaak & $\begin{array}{c}\text { Experimentele } \\
\text { taak }\end{array}$ & Proefpersonen & Resultaten \\
\hline Rennie (1991) & $\begin{array}{l}\text { Relatie tussen ervaring en } \\
\text { hoeveelheid, inhoud en } \\
\text { volgorde van recall }\end{array}$ & Interne controle & Herinneringstaak & $\begin{array}{l}60 \text { accountancystudenten; } \\
60 \text { managers met } \\
\text { gemiddeld } 6,6 \text { jaar ervaring }\end{array}$ & $\begin{array}{l}\text { Ervaren managers berinnerden } \\
\text { zich meer dan studenten. Ervaren } \\
\text { managers onthielden ook meer } \\
\text { irrelevante gegevens dan } \\
\text { studenten. Ervaren accountants. } \\
\text { in tegensteiling tot studenten. } \\
\text { gaven de 'normale' structuur van } \\
\text { het verhaal terug in de recall. }\end{array}$ \\
\hline Tubbs (1992) & $\begin{array}{l}\text { Relatile tussen ervaring en } \\
\text { kennishoeveelheid en } \\
\text { kennisorganisatie }\end{array}$ & Interne controle & $\begin{array}{c}\text { Opsommingstaak } \\
\text { Kansschattings-taak }\end{array}$ & $\begin{array}{l}23 \text { accountancystudenten; } \\
29 \text { juniors met } 1 \text { jaar } \\
\text { ervaring: } \\
21 \text { seniors met } 3 \text { jaar } \\
\text { ervaring: } \\
22 \text { managers met } 6.3 \text { jaar } \\
\text { ervaring }\end{array}$ & $\begin{array}{l}\text { Ervaren managers genereerden } \\
\text { significant meer } \\
\text { onregelmatigheden dan onervaren } \\
\text { studenten en assistenten. Tussen } \\
\text { de managers en seniors was geen } \\
\text { verschil te vinden. } \\
\text { Studenten en assistenten } \\
\text { noemden significant meer } \\
\text { incorrecte onregelmatigheden dan } \\
\text { ervaren managers. Seniors } \\
\text { verschilden niet significant van } \\
\text { zowel assistenten als van } \\
\text { managers. } \\
\text { Ervaring was positief gerelateerd } \\
\text { aan het aantal genoemide } \\
\text { atyplsche onregelmatigheden. } \\
\text { Studenten en assistenten konden } \\
\text { minder goed voorspellen hoe de } \\
\text { onregelmatigheden voorkómen } \\
\text { konden worden dan seniors en } \\
\text { managgers. }\end{array}$ \\
\hline
\end{tabular}


Vervolg Tabel 2.3

\section{accountancystudenten:}

43 assistenten met 1 jaar

ervaring:

51 managers met 5 jaar

ervaring
82 junior as

55 senior stafleden met

gemiddeld 3.5 jaar

ervaring:

agers/partners met

gemiddeld 9.3 jaar ervarin

en de representatie van
de accountancyplaninin

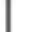


Zo is er in vrijwel alle studies naar kennis en kennisstructuur bij accountants een positief verband gevonden tussen expertise en de hoeveelheid en organisatie van de 'recall'. De bevindingen gaven bijvoorbeeld aan dat experts meer onthielden en meer 'clusters' in de 'recall' reproduceerden dan niet-experts. Een bevestiging voor het feit dat experts de beschikking hadden over schema's, kwam naar voren uit de bevindingen dat experts meer reconstructiefouten maakten, meer inferenties produceerden en vaker aandacht schonken aan gegevens die afweken van bestaande schema's.

\section{Conclusies en Onderzoeksvragen}

De hier samengevatte studies laten een aantal vragen onbeantwoord. De eerste vraag is of experts ook op het terrein van de accountancy relevante informatie sneller verwerken, (een bevinding die uit expertise-onderzoek in andere domeinen naar voren kwam). Daar geen van de hier samengevatte studies een tijdmeting bevatte, kan er weinig over worden gezegd. Een tweede kwestie is dat in geen van deze studies expliciet aandacht werd geschonken aan de wijze waarop accountants in opieiding "zoals doctoraal en postdoctoraal studenten die weinig praktijkervaring hebben, kennis representeren. Wel vond Christ (1993) dat juniors significant minder financiële informatie onthielden dan ervaren accountants. Een derde punt is dat in slechts twee cognitief georiënteercle studies een poging is gedaan te onderzoeken hoe expertise gerelateerd was aan de toepassing van kennis. Choo en Trotman (1991) onderzochten of er een directe relatie bestond tussen 'recall' en de voorspelling van een mogelijk faillissement. $\mathrm{Zij}$ vonden geen eenduidige relatie tussen deze twee variabelen. Tubbs (1992) daarentegen vond wel een relatie tussen expertise en toepassing van kennis. Managers en seniors konden in tegenstelling tot studenten en juniors goed aangeven wat de oorzaak en het gevolg waren van bepaalde problemen in de interne controleprocedures. Een andere tekortkoming is dat in slechts één studie, die van Christ (1993), werd getracht de samenhang tussen expertise-niveau in het accountancydomein en soort kennis in kaart te brengen. Aangezien het voor de accountancyopleiding en de praktijk van belang is te achterhalen in hoeverre groepen lacunes vertonen in specifleke soorten kennis, zal hier meer onderzoek naar moeten worden gedaan. Een laatste punt van kritiek 
betreft de relatief geringe aandacht die geschonken wordt aan praktische suggesties voor de accountancy opleiding en/of de accountancypraktijk. Slechts twee studies geven praktische aanbevelingen. In de studie van Christ (1993) werd verondersteld dat de controleplanning effectiever en efficiënter zal worden als seniors en managers/partners die een meer accurate probleemrepresentatie van de planning hebben, vaker bij de planning betrokken worden. Frederick et al. (1994) vonden dat er meer consistentle in de accountancystudieboeken moet komen, zodat het leerproces van de minder ervaren accountants vereenvoudigd kan worden.

Om deze tot nu toe onbeantwoorde vragen te kumnen beantwoorden zijn drie empirische studies uitgevoerd, die beschreven zljn in de hoofdstukken 3,4 en 5. De onderzoeksvragen die centraal staan in de studies zijn de volgende:

* Wat is de invloed van praktijkervaring op de ontwikkeling van een conceptueel kennisnetwerk? Wordt het kennisnetwerk uitgebreider en complexer naarmate expertise toeneemt?

- Komen ervaren accountants tot betere en meer specifieke oplossingen van casus dan minder ervaren accountants? Anders gesteld, zijn ervaren accountants beter in staat om relevante kennis toe te passen dan minder ervaren accountants?

- Bezitten ervaren accountants andersoortige kennis dan minder ervaren accountants?

- Verwerken ervaren accountants relevante informatle sneller dan minder ervaren accountants? 


\section{Een recall-studie 16}

In dit hoofdstuk wordt een studie beschreven waarin is onderzocht of expertiseniveau en feltelijke toepassing van kennis samenhangen. Daarnaast is nagegaan of expertise-niveau samenhangt met de inhoud en omvang van de kennisrepresentatie. Tenslotte is onderzocht of expertise-niveau gerelateerd is aan bestuderingstijd. Aan het onderzoek hebben viff groepen deelgenomen die verschilden in expertise-niveau. Proefpersonen kregen drie casus te lezen. Achteraf dienden ze aan te geven welke gegevens uit de casus van belang zouden kunnen zijn voor een uit te voeren accountantscontrole. Verder werd om een verklaring voor de keuze van deze gegevens gevraagd. Een laatste opdracht bestond uit het opschrijuen van datgene wat ze zich nog konden herinneren van de casus (de recall).

\section{Inleiding}

Zoals uit het vorige hoofdstuk is gebleken werd in het accountancydomein aanzienlijk minder aandacht besteed aan de relatie tussen expertiseniveau en toepassing van kennis dan in andere domeinen. Afgezien van de studies die vanuit het Lensmodel waren opgezet hebben alleen Bedard en Biggs (1991), Choo en Trotman (1991) en Tubbs (1992) empirische studies uitgevoerd waarin de relatie tussen expertise-niveau en toepassing van kennis werd onderzocht. Een belangrijke oorzaak van deze relatief geringe belangstelling zou kunnen zijn dat vele accountancy onderzoekers veronderstelden dat accountancy problemen geen eenduidige oplossingen hebben. waardoor het moeilijk te beoordelen is of proefpersonen kennis goed hebben toegepast. Lens onderzoekers, Ashton, Kleinmutz, Sullivan en Tomassini (1988), Bedard en Biggs (1991) Choo en Trotman (1991), Davis en Solomon (1989) en Tubbs (1992) erkenden wel degelijk dit normatieve probleem. Zij vonden alleen dat het geen goed excuus was om toepassing van kennis

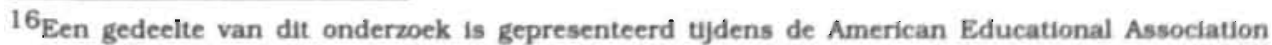
(AERA) meeting te Atlanta, GA, April, 1993. Educational Resources Information Center (ERIC) Document Reproduction Service No. ED 362 544. (Vaatstra, Boshuizen \& Schmidt, 1993a). Verder is een gedeelte gepresenteerd tijdens de summercourse van het Inter-university Center for Educational Research (ICO) aan de Universiteit van Twente (Vaatstra, Boshuizen \& Schmidt. 1993b).
} 
helemaal niet te onderzoeken. In vergelijkbare complexe of 'ill-structured' domeinen zoals geneeskunde en sociale wetenschappen was het immers wel mogelijk gebleken om toepassing van kennis te onderzoeken. Met name de resultaten die waren verkregen in een 'ill-structured' domein als het medische lieten zien dat er een consistent positieve relatie bestaat tussen expertise-niveau en toepassing van kennis (Boshuizen, 1989; Boshuizen \& Schmidt, 1992; Gilhooly, 1990; Patel \& Groen, 1986).

Ashton, Kleinmutz, Sullivan en Tomassini (1988) beweren dat de medische en accountancy setting overeenkomstige generieke kenmerken hebben. Zij stellen namelljk dat accountants bij het beoordelen van een nieuw bedrijf informatie op dezelfde wijze verwerken als artsen bij het diagnostiseren van een cllënt. Dankzij deze overeenkomstige karakteristieken in informatieverwerking veronderstellen Ashton et al. dat de inzichten die zijn verkregen in het medische domein kunnen worden toegepast op het accountancydomein. Met andere woorden: er zou dus eenzelfde positieve relatie moeten worden gevonden tussen expertise-niveau en toepassing van kennis in het accountancydomein als die, die in het medische domein is verkregen. In het hier uitgevoerde onderzoek werd dan ook verwacht dat naarmate expertise-niveau toeneemt, de toepassing van kennis verbetert.

Een van de bevindingen waarult de relatie tussen expertise en kennistoepassing naar voren komt is dat experts specifiekere kennis gebruiken bij het oplossen van een probleem dan beginners. Resultaten van een studie van Voss, Tyler en Yengo (1983) lieten zien dat de kennis die experts gebruikten echt toegespitst was op het op te lossen politieke probleem, terwijl de kennis die beginners gebruikten vrij globaal van aard was. Aan het onderzoek deden vier experts en zes beginners mee. Tot de experts behoorden vier faculteitsmedewerkers die veel kennis hadden van de Sovjet Unie. De groep beginners bestond uit zes doctoraalstudenten die pas een cursus over politiek in de Sovjet Unie hadden gevolgd. Voss et al. hebben experts en beginners hardop laten denken over een politiek probleem op het gebied van de landbouw in de Sovjet Unie. De experts bleken zich hoofdzakelijk te beperken tot de toepassing van specifieke kennis over de Sovjet Unie. De groep beginners daarentegen beperkte zich niet tot de Sovjet Unie, maar gebruikte ook globale kennis om het probleem op te lossen. Om vast te stellen dat specificiteit van kennis een algemeen kenmerk is van expertise zou specificiteit van kennis niet alleen bij politieke problemen gerelateerd moeten zijn aan expertise-niveau maar bij alle soorten problemen, inclusief 
die in de accountancy. In dat geval mag men veronderstellen dat in het hier te rapporteren onderzoek de ontwikkeling van een meer algemene naar een specifiekere toepassing van kennis naar voren moet komen in de argumentatie die ten grondslag ligt aan de oplossing.

In Hoofdstuk 2 van dit proefschrift werd betoogd dat een kennisnetwerk meer concepten gaat bevatten, en dus uitgebreider wordt, wanneer praktijkervaring toeneemt. Als iemand een uitgebreid kennisnetwerk heeft bestaat er een grotere kans dat nieuwe relevante informatie gekoppeld kan worden aan reeds bestaande kennis dan als diegene een minder uitgebreid kennisnetwerk bezit. Personen die veel kennis over een onderwerp bezitten, blijken inderdaad veel beter in staat te zijn nieuwe aansluitende informatie te onthouden dan diegenen die minder kennis hebben (Spilich. Vesonder, Chiesi \& Voss, 1979; Chiesi, Spilich \& Voss, 1979). Als aangenomen mag worden dat experts meer conceptuele kennis hebben opgeslagen dan nietexperts, dan zouden experts eveneens een uitgebreidere representatie moeten vormen van een aan hen voorgelegde casus en zou expertise-niveau positief moeten samenhangen met de afspiegeling van die representatie: de 'recall'. In verschillende domeinen is deze positieve relatie herhaaldelijk bevestigd (Adelson, 1981; De Groot, 1946, 1965; Patel \& Medley-Mark, 1986). Ook in het accountancydomein liet een aantal studies een significante relatie zien tussen expertise-niveau en 'recall' (Choo \& Trotman, 1991; Christ, 1993; Frederick, 1991; Rennie, 1991; Tubbs, 1992). In de hier uitgevoerde studie werd dezelfde positieve samenhang verwacht. Dat wil zeggen: naarmate expertise-niveau toeneemt, neemt de hoeveelheid 'recall' toe.

In Hoofdstuk 2 werd eveneens beschreven op welke wijze nieuwe informatie geïnterpreteerd wordt vanuit eerder opgedane kennis. Er werd gesteld dat met name ervaren personen tijdens het doornemen van informatie inferenties produceren die niet letterlijk in de aangeboden informatie staan maar die voortkomen uit opgedane kennis (Van Dijk \& Kintsch, 1983). Als aan ervaren personen achteraf gevraagd wordt wat ze zich nog kunnen herinneren van een casus, dan zal de 'recall' niet alleen casusinformatie bevatten, maar zullen er ook inferenties in voorkomen. Aangezien inferenties gerelateerd zijn aan aanwezige kennis is de verwachting dat experts die meer domeinkennis bezitten meer inferenties zullen produceren dan beginners. In het medische domein hebben Boshuizen (1989) en Coughlin en Patel (1987) aangetoond dat expertise-niveau inderdaad positief gerelateerd was aan het aantal inferenties. In het hier 
gepresenteerde onderzoek werd dezelfde relatie tussen expertise-niveau en inferenties verwacht. Met andere woorden: toename van expertise hangt samen met een stijging van het aantal inferenties.

Verschillende expertisestudies lieten zien dat experts sneller zijn in het bestuderen van domeinspecifieke problemen dan beginners (Boshuizen, 1989: Muzzin, Norman, Jacoby, Feightner, Tugwell \& Gyatt, 1982: Norman, Brooks \& Allen, 1989). De verklaring die hiervoor in Hoofdstuk 2 werd gegeven was dat experts vanwege een beter gestructureerd kennisnetwerk sneiler in staat zijn om relevante kennis te activeren dan niet-experts. Niet alleen in het medische domein zullen dergelijke verschillen in bestuderingstijden tussen experts en beginners naar voren komen. Ook voor het accountancydomein kan worden verwacht dat experts sneller zijn dan beginners.

Een laatste variabele waarvan de relatie met expertise-niveau onderzocht wordt betreft het type kennis dat gebruikt wordt bij het oplossen van een aangeboden casus. Christ (1993) heeft tot nu toe als enige onderzocht of er een verband bestaat tussen expertise-niveau en type kennis. Haar resultaten lieten zien dat er een significant verband bestaat tussen expertise-niveau en met name financièle kennis. Dat wil zeggen: de minder ervaren accountants onthielden significant minder financiële gegevens dan de ervaren accountants. Daarentegen bleek de 'recall' van informatie betreffende de interne controle geen significant verschil tussen de groepen op te leveren. In het in dit proefschrift uitgevoerde onderzoek werd eenzelfde verband verwacht tussen expertise-niveau en financiële kennis. Dat wil zeggen: een toename van expertise-niveau zal positief gerelateerd zijn aan de hoeveelheid financiêle kennis die men onthoudt en toepast.

Wat kan nu voorspeld worden omtrent het gedrag en de kennis van groepen wier niveau kan worden omschreven als gevorderd ('intermediate')? Naast beginners en experts, namen namelijk gevorderde accountancystudenten deel die qua hoeveelheid praktijkervaring van elkaar verschilden. In Hoofdstuk 2 is betoogd dat hoeveelheid praktijkervaring een belangrijke determinant van expertise-niveau is. De verwachting was dat ook bij de groepen studenten geldt dat naarmate de ervaring toeneemt, de prestaties toenemen. Een postdoctorale universitaire student ${ }^{17}$ die een jaar praktijkervaring heeft opgedaan zal zijn kennis dus beter kunnen toepassen dan een

\footnotetext{
${ }^{17}$ De naam postdoctorale universitaire student is gekozen bij gebrek aan een beter alternatief.
} 
vierdejaars student die nog geen ervaring heeft. Postdoctorale NIVRAstudenten ${ }^{18}$ die meerdere jaren ervaring hebben zullen hun kennis beter kunnen toepassen dan universitaire studenten met slechts éên jaar ervaring, maar ze zullen hun kennis minder goed kunnen toepassen dan de ervaren accountants.

\section{Onderzoekmethode}

\section{Proefpersonen}

In totaal deden veertig proefpersonen aan dit onderzoek mee: acht eerstejaars economiestudenten, acht vierdejaars accountancystudenten, acht postdoctorale universitaire accountancystudenten. acht postdoctorale NIVRA-studenten en acht ervaren accountants. Alle studenten studeerden aan de Rijksuniversiteit Limburg en namen vrijwillig deel aan het onderzoek. De groep eerstejaars studenten had beperkte kennis van het accountancyvak, maar had wel kennis op het gebied van Financiêle Informatie Systemen (FIS). De vierdejaars studenten hadden het accountancy doctoraal-programma bijna afgesloten en hadden alle relevante accountancy-vakken gevolgd en gehaald. Slechts twee studenten dienden het vak Voortgezette FIS nog te halen. Geen van de vierdejaars studenten had praktijkervaring. De postdoctorale universitaire studenten waren studenten die het doctorale accountancyprogramma aan een 'reguliere' universiteit hadden voltooid. Zij hadden gemiddeld twee en een half jaar praktijkervaring en waren allen werkzaam als assistent. De postdoctorale NIVRA-studenten hadden de NIVRA opleiding gevolgd en waren ingestroomd in de postdoctorale fase van de Rijksuniversiteit Limburg: Deze NIVRA-studenten hadden gemiddeld zeven jaar praktijkervaring en werkten allen als controleleider. De afname van het onderzoek vond plaats aan het einde van het postdoctorale programma. De laatste groep, de experts, bestond uit acht Registeraccountants die gemiddeld 1.2.5 jaar ervaring hadden 19 . Alle ervaren accountants hadden de functie van medewerker. De proefpersonen die op een accountants-

\footnotetext{
18 Aangezien er pas vanaf 1994 sprake is van een samengaan van NIVRA en Nijenrode zal in dit onderzoek gesproken worden van NIVRA-student.

19 Ervaringsjaren na het verkrijgen van de titel 'Registeraccountant'.
} 
kantoor werkzaam waren, werkten bijf één van de grote kantoren. Proefpersonen hebben een vergoeding van fl. 15,- gekregen.

\section{Materiaal20}

Er werden drie casus aangeboden die allen dezelfde opbouw hadden: een korte beschrijving van de administratieve organisatie gevolgd door een balans en een verlies-en-winstrekening van twee opeenvolgende jaren. De drie verschillende casus die werden aangeboden hadden betrekking op: een groothandel, een bouwonderneming en een stichting (Zie Bijlage 1). Een van de redenen om juist deze bedrijfstypes te nemen was om een zo breed mogelijk spectrum van het werkveld te bestrijken. Een groothandel, een bouwonderneming en een stichting waren gekozen, orndat zij enerzijds volgens deskundigen redelijke prototypes zijn voor de genoemde bedrijfscategorieèn en anderzijds niet zo weinig voorkomen dat ervaring bij accountants afwezig geacht kon worden ${ }^{21}$. De casus had een lengte van éen A-4.

Voorafgaand aan het daadwerkelijke onderzoek werd het materiaal, de taak en de procedure in een pilotstudie getest. Aan de hand van die uitkomsten werden nog enkele verbeteringen aangebracht.

\section{Procedure}

Voordat de proefpersonen de casus bestudeerden, werd zowel schriftelijk. als verbaal uitgelegd wat de procedure inhield. Bovendien werd nadrukkelijk aan de proefpersonen duidelijk gemaakt dat de context waarin de opdracht uitgevoerd moest worden de planningsfase was (zie Hoofdstuk 1, Figuur 1.1). De bedoeling hiervan was dat de proefpersonen allen vanuit dezelfde context de casus zouden bestuderen, namelijk vanuit de beginfase van het controleproces, een fase waarin accountants over relatief weinig informatie beschikken. De procedure was als volgt: de proefpersonen hadden als taak de casus te bestuderen en daarna alle mogelijke aandachtspunten te noteren die volgens hen van belang zouden kunnen zijn voor de eventueel uit te

\footnotetext{
20 Het materiaal werd ontwikkeld door een aantal docenten van de postdoctorale registeraccountantsopleiding van de Rijksuniversiteit Limburg.

$21 \mathrm{Er}$ bleek echter na afname dat geen van de ervaren accountants ervaring hadden met de stichting.
} 
voeren controle. Vervolgens werd de proefpersonen gevraagd wat ze zich nog van de casus herinnerden. Dat dit gevraagd zou worden was ze voor de bestudering van de casus meegedeeld. Als laatste dienden de proefpersonen de achterliggende verklaring voor de genoemde aandachtspunten op te schrijven. De proefpersonen dienden de casus één keer goed door te nemen. De bestuderingstijd was vrij en werd door de experimentator met een stopwatch geregistreerd.

$\mathrm{Na}$ het doornemen van de drie casus moesten de proefpersonen een vragenlijst met persoonlijke gegevens invullen. Gemiddeld nam de gehele afname anderhalf uur in beslag. De volgorde van de casus was over de proefpersonen zo goed mogelijk gebalanceerd.

\section{Analyse}

De aandachtspunten werden op drie manieren geanalyseerd. Er werd gekeken naar het gemiddelde aantal genoemde aandachtspunten, de accuratesse en de inhoud van de achterliggende verklaring. Het gemiddelde aantal aandachtspunten werd bepaald door alle genoemde aandachtspunten op te tellen en te middelen over de drie casus. De accuratesse van de aandachtspunten werd bepaald door de genoemde aandachtspunten te vergelijken met een daartoe opgestelde normatieve lijst van aandachtspunten. Deze lijst was door twee ervaren docenten van de postdoctorale accountancy-opleiding, onafhankelijk van elkaar. opgesteld. De lijst die uiteindeiljk als standaardnorm werd gebrutkt bestond uit de overlap tussen de twee afzonderlijke lijsten aangevuld met aandachtspunten waar de docenten na overleg consensus over hadden bereikt (Zie Bijlage 2 voor de standaardlijst met aandachtspunten). Voor iedere casus kon een maximumscore van elf punten behaald worden. In de verklaring werd aangegeven waarom de genoemde aandachtspunten voor de controle van belang waren. Deze verklaring werd geanalyseerd door de gebrulkte begrippen inhoudelijk te vergelijken op verschillen in het gebruik van type kennis. Er werd daarbij met name gekeken of er relaties gelegd werden tussen kennis over de administratieve organisatie, financiēle kennis en bedrijfskennis. Daarnaast werden de verklaringen geanalyseerd op specificiteit. Dat wil zeggen: als er in de verklaringen kenmerken werden genoemd die specifiek golden voor het type handelsbedrijf of voor industrie met 
stukproduktie of voor een dienstverlenend bedrijf dan werden die aangemerkt als specifiek. Zowel de casus als de 'recall' protocollen werden in idee-eenheden 22 verdeeld. De 'recall' kon zo gesplitst worden in 'letterlijke recall' en 'inferenties'. De letterlijke 'recall' bestond uit idee-eenheden in de 'recall' die overeenkwamen met de idee-eenheden in de casus. Inferenties bestonden uit idee-eenheden die niet letterlijk in de casus stonden. Conclusies en interpretaties werden als een inferentie gescoord als deze gebaseerd waren op twee of meer ideeeenheden. Een voorbeeld van een inferentie gebaseerd op de gegevens 'netto winst' en 'eigen vermogen' is een interpretatie als: 'de netto Winst is gering, zeker ten opzichte van het elgen vermogen'.

Verschillen in het gebruik van type informatie werd geanalyseerd door alle idee-eenheden te classificeren in één van de twee volgende ca.tegorieèn. De eerste categorie bestond uit informatie over de administratieve organisatie en interne controle (AO/IC), de tweede bestond uit financiële informatie (informatie uit de balans en de verlies-en-winstrekening).

Om de tijd nodig om een representatie te vormen vast te stellen, werd de totale bestuderingstijd geanalyseerd.

Alle groepsverschillen werden geanalyseerd door middel van variantieanalyse. Aangezien het aantal geproduceerde inferenties klein was $(0-1,8)$ en er veel knopen ('ties') in zaten, werden deze groepsverschillen door een nonparametrische variantieanalyse geanalyseerd. Om specifieke groepsverschillen na te gaan werden bovendien paarsgewijze vergelijkingen met de Scheffé F-test uitgevoerd.

De accuratesse werd door twee personen beoordeeld. De beoordelaars-overeenstemmingscoëfficlent (kappa) was .69. De uiteindelijke variantieanalyse op accuratesse werd uitgevoerd op de gemiddelde oordelen van deze beoordelaars.

${ }^{22}$ Een idee-eenheid, ook wel propositie genoemd, bestaat uit eèn of meerdere concepten waarin èn idee wordt weergegeven. 


\section{Resultaten}

\section{Aandachtspunten}

Figuur 3.1 toont aan dat er een positieve relatie was gevonden tussen expertise-niveau en het totale aantal genoemde aandachtspunten, $\quad(\mathrm{F}(4,35)=20,41, \mathrm{p}<.001)$. Dit betekent dat naarmate accountants meer praktijkervaring hadden opgedaan, zij in z'n totaliteit meer aandachtspunten signaleerden. Met name de eerstejaars studenten en de experts bleken dit significante verschil te veroorzaken, zij verschilden beide significant van de vierdejaars en van de beide groepen postdoctorale studenten.

Er bestond eveneens een positief verband tussen expertise-niveau en het totaal aantal aandachtspunten betreffende de financièle gegevens, $(\mathrm{F}(4,35)=7,50, \mathrm{p}<.0003)$. Hier bleken de postdoctorale NIVRA-studenten en de experts significant te verschillen van de andere drie groepen. Wat de $\mathrm{AO} / \mathrm{IC}$-informatie betreft bleken alleen de eerstejaars studenten significant af te wijken van de andere groepen $(\mathrm{F}(4,35)=8.99, \mathrm{p}<.001)$.

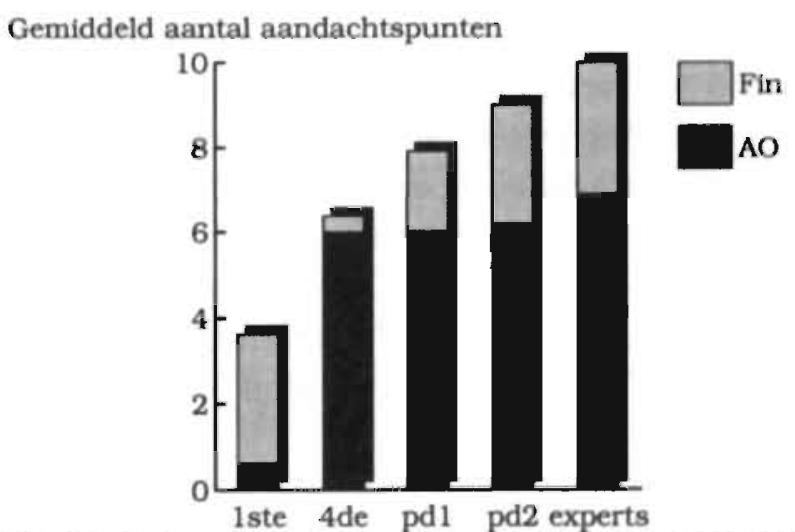

Figuur 3.1 De relatie tussen expertise-niveau en de gemiddelde hoeveelheid aandachtspunten; $\mathrm{AO}$ staat voor informatie over de administratieve organisatie en interne controle; Fin staat voor informatie uit de balans en de verlies-en-winst rekening: 1 ste = eerstejaars studenten; $4 \mathrm{de}=$ vierdejaars studenten; pd 1 = postdoctorale universitaire studenten: pd2 = postdoctorale NIVRA-studenten

Figuur 3.2 laat zien dat expertise-niveau positief was gerelateerd aan accuratesse, $(\mathrm{F}(4,35)=29.96, \mathrm{p}<.001)$. Naarmate praktijkervaring toenam, signaleerden accountants meer aandachtspunten die overeen- 
kwamen met de standaardlijst. Dus, niet alleen signaleerden experts meer aandachtspunten, ook kwam een gedeelte van die aandachtspunten vaker overeen met een normatieve lijst.

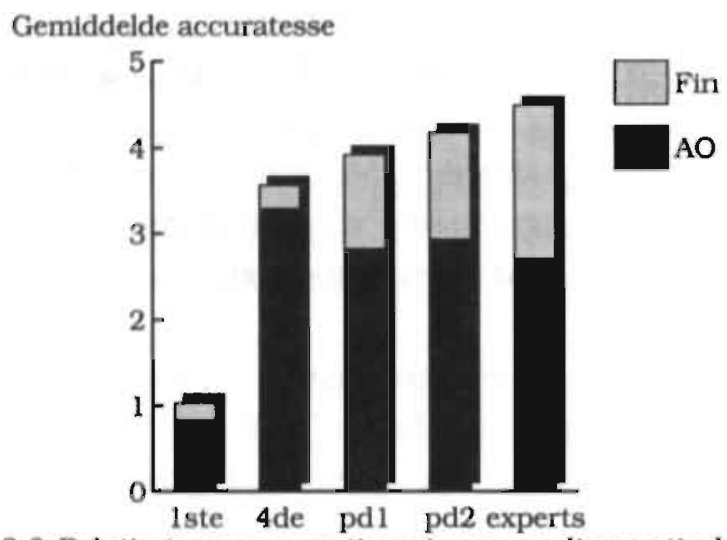

Figuur 3.2 Relatie tussen expertise-niveau en diagnostische accuratesse; AO staat voor informatie over de administratieve organisatie en interne controle; Fin staat voor informatie uit de balans en de verlies-en-winstrekening: 1ste = eerstejaars studenten; $4 \mathrm{de}=$ vierdejaars studenten; pd1 = postdoctorale universitaire studenten; pd2 = postdoctorale NIVRA-studenten

Het waren de eerstejaars studenten die significant minder accuraat presteerden dan de andere groepen. In het gebruik van financiële informatie werd eveneens een verschil tussen de groepen gevonden $(\mathrm{F}(4,35)=10.52, \mathrm{p}<.001)$. Hier waren het de postdoctorale NIVRAstudenten en de ervaren Registeraccountants die significant verschilden van de eerstejaars en de vierdejaars studenten. De postdoctorale universitalre studenten vertoonden geen significante verschillen van de andere groepen. $\mathrm{Bij}$ de $\mathrm{AO} / \mathrm{IC}$-informatie vertoonden alleen de eerstejaars studenten een significant verschil met alle andere groepen $(\mathrm{F}(4,35)=24,43, \mathrm{p}<.001)$.

\section{Verklaringen}

De verklaringen die de verschillende groepen bij de aandachtspunten gaven, vertoonden nogal wat verschillen. Kenmerkend voor de eerstejaars studenten was dat ze weinig aandachtspunten gaven en dat. de bijbehorende verklaringen kort waren. Zij noemden veelvuldig begrippen als 'liquiditeit' en 'solvabiliteit' met als verklaring dat het belangrijke graadmeters zijn om te checken of een onderneming 
rendabel is. Gegevens werden nauwelijks aan elkaar gerelateerd. Ook waren er weinig verschillen tussen de verklaringen voor de aandachtspunten bij de verschillende bedrijfstypes: handel, industrie en dienstverlening. Een voorbeeld van aandachtspunten plus de bijbehorende verklaringen die de eerstejaars student (pp 1.1) bij de casus 'Bouw BV' heeft gegeven wordt in Figuur 3.3 getoond.

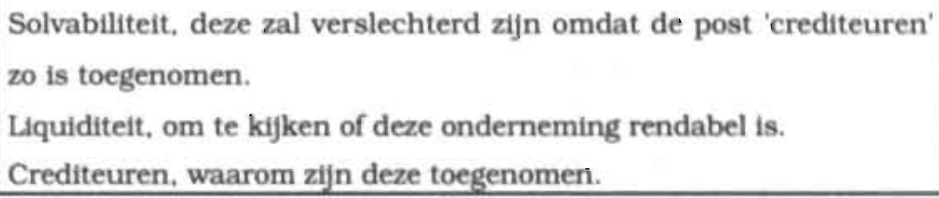

Figuur 3.3. Verklaringen van eerstejaars student, pp 1.1

Een geheel andere indruk gaven de vierdejaars studenten. Hun verklaringen bevatten vaak begrippen als 'adequaatheid', 'volledigheid' en 'juistheid'. De vierdejaars studenten gaven net als de eerstejaars studenten bij alle drie bedrijfstypes dezelfde soort aandachtspunten en verklaringen. Uit de verklaringen kan bovendien geconcludeerd worden dat vierdejaars studenten veel AO/IC-begrippen gebruikten, maar dat ze niet of nauwelijks financiēle gegevens gebruikten. Deze vierdejaars studenten gebruikten bij het geven van verklaringen hoofdzakelijk kennis uit het vak: administratieve organisatie. Slechts een enkele student schonk aandacht aan de balans en verlies-en-winst rekening. Als dat wel een keer gebeurde, dan had dat eerder de vorm van een vraag dan van een verklaring. In Figuur 3.4 wordt een voorbeeld gegeven van de aandachtspunten met de bijbehorende verklaringen die een vierdejaars student bij de casus 'Bouw BV' heeft genoemd.

\footnotetext{
Onderhandenwerk, door de lange duur van de projecten is de waardering op de balans van essentieel belang.

Rentelasten, de begroting dient op een correcte wijze te worden opgesteld wil deze bereikbaar zijn voor een analyse.

Beoordeling voortgangsprojecten (van o.a. winstneming). de voortgang is van belang voor de winstneming.
} 
Begroting versus werkelijk: wat zijn de verschillen? Is er door de lange duur van het project een goede planning van de activiteiten?

Figuur 3.4 Verklaringen van vierdejaars student, pp 4.1De hoge post debiteuren.

Personeelskosten. Is de verhouding (loon)belasting en personeelskosten van een adequate omvang?

Vervolg Figuur 3.4

De inhoud van de verklaringen van de postdoctorale universitaire studenten verschilde in die zin van de Inhoud van de vierdejaars studenten, dat de verklaringen iets meer waren toegespitst op het type bedrijf. Dat wil zeggen, de aandachtspunten en verklaringen werden meestal specifieker ingevuld naar een handelsbedrijf, een industrieel bedrijf op projectenbasis of een dienstverlenend bedrijf. Verder gebruikten ook de postdoctorale universitaire studenten veelvuldig $\mathrm{AO} / \mathrm{IC}$-termen als 'juistheid' en 'volledigheid'. In Figuur 3.5 laten de verklaringen van één van de postdoctorale universitaire studenten (R6) bil de casus 'Bouw BV' zien, dat de inhoud toch vrij algemeen bleef: 'een contractenregister is de basis voor de volledigheid van de opbrengstverantwoording'. In het algemeen waren de verklaringen van de postdoctorale universitaire groep iets meer gebaseerd op financièle gegevens dan die van de vierdejaars studenten. Met name bij de casus van het bouwbedrijf worden financiële posten als 'onderhanden werk', 'materiaalkosten', en 'brutowinst' een aantal keren genoemd. Ook bij deze groep werden de financièle gegevens echter onderling nauwelijks gerelateerd.

Zijn er contracten aanwezig van de projecten, een contractenregister is de basis voor de
volledigheid van de opbrengstverantwoording.
Typologie is stukproduktie (bouwonderneming). Controle geschiedt aan de hand van order-
gewijze voor/nacalculatie. Intern wordt per project zo'n ordergewijze voor/nacalculatie
uitgevoerd, aansluiting met financiěle administratie. Dit is van belang om de onderliggende
projecten te beheersen o.a. in verband met te nemen winst en te nemen verlies.
Intern aansluiting aantal uren op projecten (jobtime en shoptime). Zijn alle uren
verantwoord en op het juiste project terecht gekomen.
Onderhandenwerk en gefactureerde termijnen, worden verliezen tijdig. genomen
(waarderingsprobleem) en is de stand van het onderhandenwerk niet te hoog, afloop-
controle.

Figuur 3.5 Verklaringen van postdoctorale universitair student, pp R.6 
Toename werk derden en afname materiaalkosten, wat is de oorzaak hiervan? Afname winst t.o.v. omzet, afname bruto winstmarge, van gehele markt of alleen van dit bedrijf?

\section{Vervolg Figuur 3.5,}

Bij de postdoctorale NIVRA-studenten ziet de inhoud van de verklaringen er anders uit. Deze studenten gaan ten eerste vrij praktisch te werk door aan te geven hoe berekend zou kunnen worden of een post juist gewaardeerd is. Maar ook bij deze ervaren studenten kwamen de AO/IC-begrippen 'volledigheid', 'juistheid' en 'functiescheiding' vaak voor. In de verkiaringen van de NIVRA-studenten kwamen, in tegenstelling tot de verklaringen van de minder ervaren studenten, zowel AO/IC-kennis als financiêle kennis voor. De financièle gegevens die de postdoctorale NIVRA-studenten noemcien werden. soms in relatie tot andere financiële gegevens genoemd. Bijvoorbeeld: 'Het bedrijfsresultaat dat is gedaald geeft waarschijnlijk aan dat de winstmarge onvoldoende is geweest op de extra omzet, om de kosten eruit te kunnen halen'. Een paar NIVRA-studenten gingen nog een stap verder en trachtten de financièle gegevens te koppelen aan de $\mathrm{AO} / \mathrm{IC}$-informatie. Er werd bijvoorbeeld gezegd: 'De omzet en het bedrijfsresultaat is verslechterd, wat wel eens aan zou kunnen geven dat er of interne problemen zijn of dat de markt niet meewerkt'. In Figuur 3.6 worden de aandachtspunten met bijbehorende verklaringen die de postdoctorale NIVRA-student (pp N4) over 'Bouw BV' heeft gegeven.

\footnotetext{
Vaststelling interne tarieven (beoordeling) materieel, loonkosten en overhead, toetsing doorbelasting/dekking uren (man en materieel) $\mathrm{x}$ tarief.

Consistente grondslag afschrijvingen gebouwen en materieel. Kosten berekening en waardering balansposten.

Mutatie onderhanden werk in Verlies en winst rekening versus Onderhanden werk in balans sluit ciffermatig niet. Wat is de verklaring voor het geconstateerde verschil?

Beoordeling periodieke rapportage financieel en per project per bouwfase met voor- en nacalculatie, Cijferbeoordeling t.b.v. verdere controle aanpak.

Aansluitingen verwerkte toeslagen overheadkosten en dekking toeslag in werkelijke overheadkosten, beoordelen dekking t.o.v werkelijke kosten (eventueel normcontrole van de toeslag.
}

Figuur 3.6 Verklaringen van postdoctorale NIVRA student, pp N4 
Waarom aanzienlijk lagere materieelkosten, analyse (beleid?).

Beoordeling winstneming naar rato van realisatie bij balanspost, van onderhanden werk en verliesneming bif constatering, toetsing waardering onderhanden werk.

Beoordeling intern opgestelde verklaringen voor materiêle verschillen, toetsing interne controle.

Gegevensgerichte controle op mutaties in de posten: algemene reserves, pensioenvoorziening, backservice, garantievoorziening, langlopende schulden. Dit om de juistheid en de volledigheid van de mutaties te controleren, tevens voorzover van toepassing, verbanden met andere 'grootheden' als betalingen, omzet, pensioenuregels, algemene reserves, dividend. langlopende schulden en garantievoorziening.

Aansluiting financieringskosten met bron. juistheid en volledigheid rentekosten.

\section{Vervolg Figuur 3.6}

De aandachtspunten en de verklaringen van de experts werden in eerste instantie gebaseerd op het specifieke bedrijf. Daarbij werden de financiële gegevens hoofdzakelljk geïnterpreteerd vanult de karakteristieken van dat bedriff en de daarbij behorende informatie over de AO/IC. Dit blijkt uit opmerkingen als: 'In het algemeen is bÿ aannemers van belang' en 'Gegeven de beschrijuing van dit bedrijf en de balans had' ik dit gegeven in de verlies-enwinstrekentng niet verwacht. In de verklaringen van de experts kwamen veel gerelateerde gegevens voor en werden maar weinig opmerkingen over losstaande gegevens gemaakt. De ervaren accountant in Figuur 3.7 noemde bijvoorbeeld eerst de wijze van bepallng van het resultaat als aandachtspunt en gaf daama aan dat het geringe 'eigen vermogen' en de afhankelijkheid van financiering van derden het bedrijf nog meer de neiging geven tot verschulving in de 'winst' en 'kosten'. De begrippen die de ervaren accountants noemden waren verder: brutomarges, goederenbeweging. deblteurenbewaking, waardering onderhanden werk, volledigheid van opbrengsten en juistheid van kosten. Wat met name karakteristiek was voor de accountants die specifieke ervaring hadden met bouwbedrijven, was dat zij veel begrippen gebruikten die niet in de casus gegeven waren. Bijvoorbeeld begrippen als: 'wet ketenaansprakelijkheid', 'offertecalculatie' en 'regiewerken'. Samenvattend, de verklaringen van de experts bevatten duidelijk meer financièle gegevens dan $\mathrm{AO} / \mathrm{IC}$-gegevens. De financièle gegevens werden niet als op zichzelf staand behandeld, maar werden geîntegreerd met $\mathrm{AO} / \mathrm{IC}$-kennis en bedrijfskennis toegepast.

De aandachtspunten en verklaringen bif 'Bouw BV' van de ervaren accountant (pp E3) worden in Figuur 3.7 weergegeven. 
Onderhandenwerk positie en verliesreservering ultimo boekjaar, beīnvloeding van deze post is heel goed mogelijk, waarborgen voornamelijk via AO. Deze posities bepalen in sterke mate de hoogte van het resultaat.

Wijze van bepaling van het resultaat via tussentijdse oplevering (percentage of completion). Bij winstneming via voortgang projecten moet dit bewaakt worden voor het te vroeg of te laat nemen van winsten/verliezen. Als er geen duidelijk te toetsen criteria aan ten grondslag liggen dan is willekeur mogelijk.

Gezien tamelijk gering Eigen Vermogen en afhankelijkheid van financiering van derden, tendens tot infleren van winst d.w.z. verschuiving van kosten op projecten, c.q. opbrengsten.

Debiteurenpositie, aflooprisico's, wat is hierin begrepen aan gefactureerde voorschotten, nog niet betaald. Indien facturen niet worden betaald, kan dit te maken hebben met het feit dat de afnemer het nog niet eens is met de oplevering (of fasen).

Handhaving van de functiescheiding: werken, administratie, projectleider en uitvoerder. Functiescheiding is essentieel om hier überhaupt accountantscontrole mogelijk te maken. Zonder dit is beinvloeding van de gegevens eg onttrekking, van waarden voor een persoon mogelijk, zonder dat dit geconstateerd wordt.

Analyse van de resultaten op de werken en goedkeuring hiervan door de betrokken functionarissen.

Wat is de reden van de achteruitgang in aandeel materiaal en het hogere aandeel werk derden.

In het algemeen is bij aannemers van belang: welke totaal verbanden zijn in de administratie vastgelegd en wat zijn de verbanden tussen financiele administratie en werkenadministratie. Totaalverbanden geven extra zekerheid op de volledige verwerking van de gegevens, zeker als deze ook zijn gebaseerd op funktiescheidingen (afstemming van onafhankelijk tot standgekomen totalen).

Van belang is de controle met contracten en de wijze waarop de opbrengsten (en dus winsten) worden toegerekend aan de verschillende fasen in het project.

Figuur 3.7 Verklaringen van expert, pp E3

\section{Recall}

Figuur 3.8 laat zien dat, in tegenstelling tot de verwachting, expertise-niveau weinig effect had op de gemiddelde hoeveelheid letterlijke 'recall', $(\mathrm{F}(4 ., 35)=0.52, \mathrm{p}<0.73)$. De verschillen tussen de hoeveelheid financiële informatie die de groepen in hun letterlijke 'recall' weergaven, bleek ook niet significant te zijn, $(\mathrm{F}(4,35)=1.87$, $\mathrm{p}<0.15$ ). 
De hoeveelheid $\mathrm{AO} / \mathrm{IC}$-informatie die de groepen weergaven in de 'recall' bleek eveneens niet significant te verschillen, $(F(4,35)=0.68$. $\mathrm{p}<0.62$ ).

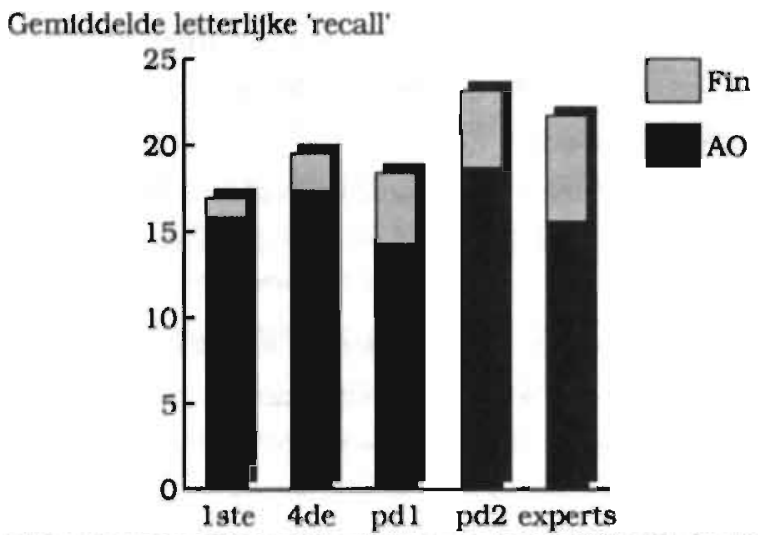

Figuur 3.8 De relatie tussen expertise-niveau en de gemiddelde hoeveelheid letterlijke 'recall'. AO staat voor informatie over de administratieve organisatie en interne controle; Fin staat voor informatie ult de balans en de verlies-en-winstrekening: 1 ste $=$ eerstejaars studenten; 4 de $=$ vierdejaars studenten; pd $1=$ postdoctorale universitaire studenten; pd2 = postdoctorale NIVRA-studenten

\section{Inferenties}

Figuur 3.9 toont een significante relatie tussen expertise-niveau en de hoeveelheld inferenties geproduceerd in de 'recall' (Chi-kwadraat $=19.53 . \mathrm{df}=4 . \mathrm{p}<.0007)$. Zoals verwacht was praktijkervaring gerelateerd aan het geven van correcte interpretaties en het trekken van de juiste conclusies. De postdoctorale NIVRA-studenten en de expertgroep bleken significant meer inferenties te produceren dan de eerstejaars studenten, de vierdejaars studenten en de postdoctorale universitaire studenten.

De inferenties die gebaseerd waren op de financiêle informatie waren eveneens gerelateerd aan praktijkervaring. (Chi-kwadraat $=$ 15.49. $\mathrm{df}=4 . \mathrm{p}<.005$ ). Ten aanzien van deze financiêle inferenties verschilden de postdoctorale NIVRA-studenten en de experts significant van de eerstejaars studenten en van de vierdejaars studenten. De postdoctorale universitaire studenten bleken van geen van de andere deelnemende groepen significant te verschillen. Er werden geen significante verschillen gevonden tussen de groepen voor wat betreft het 
aantal inferenties gebaseerd op de $\mathrm{AO} / \mathrm{IC}$ (Chi-kwadraat $=4,97$, $\mathrm{df}=4, \mathrm{p}<.29$ ).

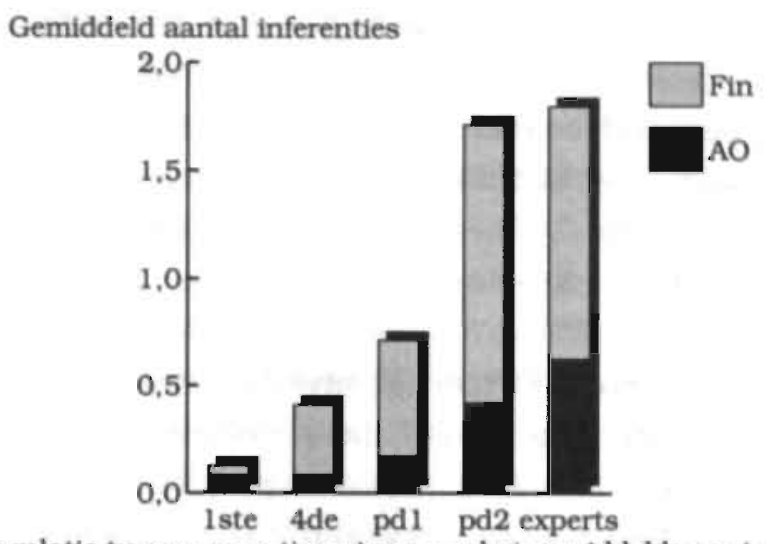

Figuur 3.9 De relatie tussen expertise-niveau en het gemiddelde aantal inferenties; AO staat voor informatie over de administratieve organisatie en interne controle; Fin staat voor informatie uit de balans en de verlies-en-winstrekening: 1ste = eerstejaars studenten; $4 \mathrm{de}=$ vierdejaars studenten; $\mathrm{pd} 1$ = postdoctorale universitaire studenten; pd2 = postdoctorale NIVRA-studenten

\section{Bestuderingstijd}

In Figuur 3.10 wordt de gemiddelde bestuderingstijd weergegeven. De groepen bleken significante verschillen te vertonen in bestuderingstijd $(\mathrm{F}(4,35)=4,3, \mathrm{p}<.02)$. De verwachting dat experts sneller zouden zijn dan de minder ervaren groepen werd echter niet bevestigd. Het waren de vierdejaars studenten die de casus significant sneller doornamen dan de postdoctorale NIVRA-studenten. De resterende groepen verschilden qua bestuderingstijd niet significant van elkaar.

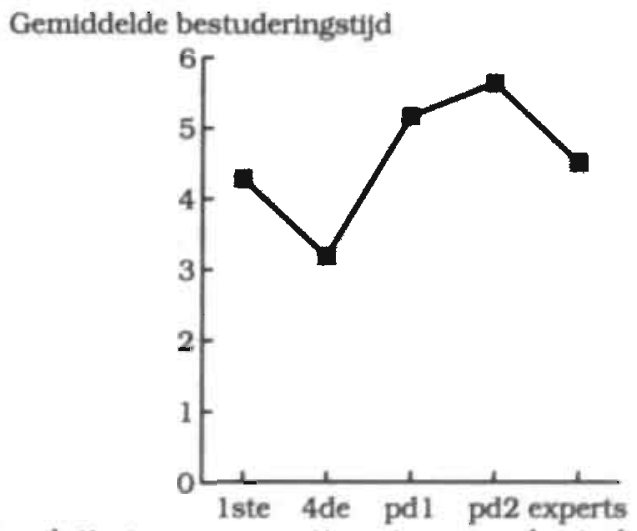

Figuur 3.10 De relatie tussen expertise-niveau en bestuderingstijd in minuten: 1 ste $=$ eerstejaars studenten: 4 de $=$ vierdejaars studenten; pd $1=$ postdoctorale universitaire studenten; pd2 = postdoctorale NIVRA-studenten 


\section{Discussie en Conclusies}

In het hier beschreven onderzoek werd allereerst de relatie tussen expertise-niveau en toepassing van kennis onderzocht. Vervolgens werd nagegaan of er een verband bestaat tussen expertise-niveau en de hoeveelheid informatie die onthouden wordt. Daarnaast werd bestudeerd of expertise-niveau en het type kennis positief gerelateerd zijn. Als laatste werd onderzocht of expertise-niveau en bestuderingstijd samenhangen.

De resultaten lieten zien dat expertise-niveau positief gerelateerd is aan de toepassing van kennis. De meer ervaren accountants signaleerden gemiddeld meer relevante aandachtspunten dan de andere groepen. Bovendien bleken de ervaren accountants meer aandachtspunten te noemen die overeenkwamen met een standaardlijst. Daarnaast lieten de verklaringen die gegeven werden bij de aandachtspunten zien dat de kennis die werd toegepast speclfieker was naarmate expertise-niveau toenam.

Ook werd er een positief verband gevonden tussen expertise-niveau en het type kennis dat gebruikt wordt. De postdoctorale NIVRAstudenten en de experts gebruikten significant meer financiële kennis dan de vlerdejaars studenten en de postdoctorale universitaire studenten. Vooral de vierdejaars studenten richtten zich geheel op het toepassen van kennis van de administratieve organisatie en de interne controle.

De relatie tussen expertise-niveau en de hoeveelheld kennis die werd geproduceerd in de 'recall' bleek niet in overeenstemming te zijn met de verwachtingen. De hoeveelheid kennis werd onder andere afgeleid uit de hoeveelheid letterlijke 'recall': De resultaten gaven aan dat experts niet meer eenheden onthielden die letterlijk overeenkwamen met eenheden in de casus dan minder ervaren proefpersonen. Dit resultaat komt niet overeen met de resultaten uit andere studies die onder andere verricht zijn in het accountancy domein. Een oorzaak voor het feit dat de verschillen in 'recall' zo klein waren is mogelijk de onbeperkte bestuderingstijd. In het medisch domein zijn onderzoeken verricht waaruit bleek dat experts vooral bij korte bestuderingstijden significant verschillen van de minder ervaren groepen (Schmidt \& Boshuizen, 1993). 
Een tweede variabele waaruit de hoeveelheid kennis afgeleid kan worden is het aantal inferenties die in de 'recall' voorkomen (Van Dijk \& Kintsch, 1983). Het aantal inferenties bleek in de hier uitgevoerde studie een significante relatie te hebben met expertise-niveau. Ervaren accountants bleken meer inferenties te maken dan minder ervaren accountants. De relatie tussen expertise-niveau en de hoeveelheid kennis is dus wat het aantal inferenties betreft bevestigd.

De samenhang tussen expertise-niveau en de bestuderingstijd sloot niet helemaal aan bij de verwachting. Het waren namelijk niet de experts die de informatie het snelst verwerkten, maar de vierdejaars studenten. Met name de twee postdoctorale groepen bleken meer tijd te besteden aan het doornemen van de casus. Een mogelijke verklaring hiervoor is dat deze studenten wel veel kennis bezitten, maar dat die kennis niet zodanig is gestructureerd dat ze die kennis snel kunnen activeren. De vierdejaars studenten daarentegen bleken zeer snel te zijn, wellicht omdat zij nog maar weinig kennis hebben die kan worden geactiveerd. De experts die eveneens snel waren gebruikten bij het geven van de aandachtspunten zowel financiêle gegevens en gegevens over de administratieve organisatie en de interne controle als bedrijfskenmerken. De kennis van de experts is vermoedelijk goed georganiseerd, waardoor ze snel kan worden geactiveerd en toegepast. Waarom de eerstejaars langzamer zijn dan de vierdejaars studenten, is vooralsnog onduidelijk.

Ten aanzien van de verwachting dat kennis zich ontwikkelt van eenvoudige conceptuele netwerken naar complexe netwerken kan geconcludeerd worden dat de resultaten deels de beweringen in Hoofdstuk 2 bevestigen.

De vierdejaars studenten interpreteren slechts gegevens vanuit de administratieve organisatie en de interne controle $(\mathrm{AO} / \mathrm{IC}$ ) en relateren deze niet aan de financièle gegevens. De resultaten suggereren dat deze studenten een conceptueel netwerk bezitten waarin redelijk veel $\mathrm{AO} / \mathrm{IC}$-concepten zitten. Gezien de toch summiere verklaringen die deze studenten geven bij de aandachtspunten mag men veronderstellen dat het $\mathrm{AO} / \mathrm{IC}$-kennisbestand van deze vierdejaars studenten bestaat uit een beperkt aantal losse concepten die niet sterk met elkaar verbonden zijn. Aangezien deze studenten weinig andere kennis 
activeren dan $\mathrm{AO} / \mathrm{IC}$-kennis kan geconcludeerd worden dat er vanuit het AO/IC-netwerk weinig 'links' naar andere conceptule netwerken worden gelegd.

De postdoctorale universitalre groep past naast kennis over de administratieve organisatie en de interne controle $(\mathrm{AO} / \mathrm{IC})$ iets meer financiële kennis toe bij het oplossen van de casus dan de vierdejaars studenten. Ook zij relateren echter weinig AO/IC-begrippen aan financielle gegevens. Het conceptuele netwerk van deze groep bestaat waarschijnlijk uit een AO/IC-netwerk dat behoorlijk veel onderlinge relaties bevat, maar het lijkt nauwelijks gerelateerd te zijn aan het financlële netwerk. De verklaringen bij de aandachtspunten laten zien dat deze studenten weinig financiële concepten met elkaar verbinden. Het financiele netwerk is bij deze studenten wellicht nog niet zo complex en bevat waarschijnlijk slechts een aantal concepten die verbonden zljn met andere financiele concepten binnen het netwerk.

De postdoctorale NIVRA-studenten maken aanzlenlijk meer gebruik van hun financiële kennis dan de postdoctorale universitatre studenten. De verklaringen van de NIVRA-studenten laten zien dat ze verschillende financiële posten aan elkaar relateren en dat ze zelfs informatie over de administratieve organisatie en financiële gegevens proberen te integreren. De NIVRA-studenten bezitten waarschijnlijk een uitgebreider $\mathrm{AO} / \mathrm{IC}$-netwerk waarin $\mathrm{AO} / \mathrm{IC}$-concepten redelijk aan elkaar gerelateerd zijn dan de minder ervaren groepen. Voor hun financielle netwerk zal hetzelfde gelden: ook dit netwerk zal uitgebreid z!jn met veel aan elkaar gerelateerde concepten. Bovendien lijkt het erop dat er buj de NIVRA-studenten meer 'links' bestaan tussen deze conceptuele netwerken dan bij die van de minder ervaren vierdejaars en de piostdoctorale universitaire studenten. Een ander verkregen resultaat wees uit dat de NIVRA-studenten relatief veel inferenties produceerden in de 'recall'. Dat duidt er eveneens op dat deze groep meer conceptuele kennis heeft die de informatie uit de casus verrijkt. Gezien de bestuderingstijd van deze ervaren studenten zou gesteld kunnen worden dat de netwerken nog niet dusdanig gestructureerd zijn dat aanwezige kennis snel gevonden en geactiveerd kan worden.

De ervaren accountants pasten niet alleen kennis van de administratieve organisatie en interne controle (AO/IC) en de financiêle kennis toe, maar gebruikten ook veel specifieke bedrijfs- 
kennis. Deze bedrijfskennis blijkt met name uit de verklaringen waarin zij regelmatig naar de praktijk refereren. Zij maken bijvoorbeeld opmerkingen als: 'dit geldt voor bouwbedriven in het algemeen' of: 'in het algemeen is dit bij aannemers van belang'. Verder blijkt dat deze experts de gegevens niet zien als losstaande feiten, maar dat ze de financiële gegevens onderling relateren en dat ze financiële gegevens relateren aan $\mathrm{AO} / \mathrm{IC}$-gegevens en aan specifieke bedrijfsgegevens. Tevens laat het aantal inferenties die de experts in de 'recall' geproduceerd hebben zien, dat experts veel conceptuele kennis bezitten van waaruit informatie uit een voorgelegde casus geïnterpreteerd en aangevuld wordt. De kennisnetwerken van de experts lijken uitgebreid en complex te zijn.

Verwacht werd, mede op basis van het onderzoek van Christ (1993) dat er verschillen zouden optreden tussen de groepen ten aanzien van hun financiěle kennis. Dat de vierdejaars studenten de financièle informatie feitelijk negeren en enkel aandacht besteden aan de informatie over de AO/IC was echter niet verwacht. Een mogelijke verklaring hiervoor zou kunnen zijn dat deze studenten in het licht van het landelijk AO-examen zo voorbereid zijn op AO/IC-problemen, dat ze de diagnostische opdracht in deze studie: 'geef aandachtspunten' alleen vanuit die $\mathrm{AO} / \mathrm{IC}$-context kunnen interpreteren. Het zou dan ook kunnen dat deze studenten wel financiēle kennis hebben, maar dat ze door de context en de inhoud van de casus worden afgeleid. Zo gezien is de afwezigheid van financiële kennis in de aandachtspunten en verklaringen het resultaat van een andere interpretatie van de taak. Een andere verklaring zou kunnen zijn dat deze studenten nog niet in staat zijn om financiēle kennis toe te passen op een accountancyprobleem. Zoals in het eerste hoofdstuk werd beschreven, hebben deze studenten wel financiēle vakken gevolgd, zoals Financièle Informatie Systemen en Externe Berichtgeving, maar hebben ze geen cursus gehad waarin specifiek aandacht. werd besteed aan het toepassen van financiële kennis op een accountancyprobleem.

De resultaten die in deze eerste studie werden gevonden suggereren dat expertise-niveau inderdaad sterk gerelateerd is aan de aard van kennis die personen hebben over een domein. Daarbij vallen twee bevindingen op: de afwezigheid van aanwijzingen voor het gebruik van financiële kennis bij personen met minder expertise in het 
accountancydomein, en het verschijnen van specifieke, bedrijfstakgerelateerde redeneringen in de protocollen naarmate expertise toeneemt.

In de volgende twee studies werd nader onderzocht wat de reden is dat minder ervaren studenten weinig financiële kennis gebruikten. De verklaring kan zijn dat studenten onvoldoende financiële kennis bezitten of dat ze moeite hebben om deze kennis toe te passen of dat ze de taak anders hebben geinnterpreteerd. Daarnaast werd nagegaan of er met andere onderzoeksmethodes aanvullende resultaten voor de veronderstelde kennisontwikkeling kon worden verkregen. 


\section{Een hardopdenk-studie 21}

In dit vierde hoofdstuk wordt een studie beschreven waarin nader werd onderzocht of er een samenhang bestaat tussen expertise-niveau en het gebruik van financièle kennis. Tevens werd bestudeerd of expertise-niveau en de uitgebreidheid en complexiteit van de kennisrepresentatie aan elkaar zijn gerelateerd. Aan het hier gepresenteerde onderzoek hebben vier groepen variërend qua expertise-niveau deelgenomen. Proefpersonen kregen twee casus aangeboden die ze hardopdenkend dienden door te nemen. Net als in de eerste studie werd hun achteraf geuraagd welke gegevens ze van belang achtten voor de wit te voeren controle en waarom.

\section{Inlelding}

Resultaten uit het onderzoek dat werd beschreven in Hoofdstuk 3 geven aan dat de deelnemende groepen nogal verschilden in het gebruik van financiële informatie. Het bleek dat met name de onervaren vierdejaars studenten en de beperkt ervaren postdoctorale universitaire studenten nauwelijks aandacht besteedden aan de financièle informatie die in de casus werd aangeboden. Deze groepen gaven de indruk voornamelijk kennis over informatie over de administratieve organisatie en interne controle (AO/IC) te gebruiken bij de interpretatie van de casus. Daarentegen maakten de meer ervaren postdoctorale NIVRA-studenten en de ervaren accountants relatief veel gebruik: van financiële kennis bij de beoordeling van de beschreven bedrijven. Een mogelijke verklaring voor deze verschillen die in het vorige hoofdstuk werd genoemd is dat de inhoud van de gebruikte casus, de minder ervaren groepen als het ware 'uitnodigden' om slechts $\mathrm{AO} / \mathrm{IC}$-kennis toe te passen. Dit was een reden om in het hier gerapporteerde vervolgonderzoek

${ }^{21}$ Een gedeelte van dit onderzoek is verschenen in Onderwijsonderzoek in Nederland en Vlaanderen, 1994. (Vaatstra, Boshuizen \& Schmidt, 1994). Daarnaast is een gedeelte verschenen in Educational Innovation in Economics and Business Administration. The case of Problem Based Learning. Gijselaers, W. H. Tempelaar, D. T., Keizer, P. K., Blommaert, J. M., Bernard, E. M. en Kasper. H. (Eds.). (Vaatstra. Boshuizen \& Schmidt, 1995a). 
materiaal aan te bieden waarin voornamelijk financiële gegevens staan. De centrale vraag in het hier gepresenteerde onderzoek is of de groepen op dezelfde wijze verschillen in het toepassen van financiële kennis als de deelnemende groepen in de studie die is beschreven in Hoofdstuk 3. Op basis van die studie werd verwacht dat er een samenhang bestaat tussen expertise-niveau en de hoeveelheid financiële aandachtspunten die worden geproduceerd.

Een andere bevinding uit het vorige onderzoek was dat de groepen opmerkelijk verschilden in de aard van de achterliggende verklaringen die gegeven worden bif de aandachtspunten. De vierdejaars studenten en de postdoctorale universitadre studenten bleken nauwelijks gegevens met elkaar In verband te brengen, terwijl de meer ervaren groepen dit wel deden. Vergelijkbare resultaten zijn gevonden op het gebled van de natuurkunde door Chi, Feltovich en Glaser (1981) en Feltovich (1981). Volgens deze onderzoekers kan men ult deze resultaten afleiden dat onervaren studenten in tegenstelling tot ervaren proefpersonen niet in staat zijn om de afzonder11jke gegevens te interpreteren in de context van een samenhangend theoretisch kader. De onervaren studenten kunnen de gegevens slechts interpreteren als afzonderlijke losse eenheden, terwijl de meer ervaren proefpersonen de verschillende elementen van een probleem in een groter geheel integreren. Ook in de sociale wetenschappen zljn soortgelijke resultaten gevonden. Zoals in het vorige hoofdstuk reeds is beschreven, hebben Voss, Tyler en Yengo (1983) experts en novieten hardop laten denken over een politiek probleem op het gebied van de landbouw in de Sovjet Unie. De inhoud van de protocollen werd geanalyseerd met behulp van het argumentatiemodel van Toulmin (Toulmin et al. 1979). Om na te gaan welke verschillen er zijn tussen beginners en experts met betrekking tot de argumentatie, hebben Voss et al. onder andere het totaal aantal eenheden geteld waarmee de groepen hun argumentatie onderbouwden. Resultaten gaven aan dat experts een argumentatie onderbouwden met gemiddeld 7,1 eenheden per argument, terwijl de minder ervaren studenten gemiddeld 2,6 eenheden gebruikten om een argument te onderbouwen. Als deze bevinding doorgetrokken wordt naar het hier uitgevoerde onderzoek, dan moeten er vergelijkbare verschillen bestaan tussen onervaren en ervaren accountants bij het onderbouwen van de genoemde aandachtspunten. De verwachting was dus dat als de proefpersonen gevraagd wordt verklaringen bij de aandachtspunten te geven, de verklaringen van de onervaren proefpersonen 
minder gegevens bevat per aandachtspunt dan die van de meer ervaren proefpersonen.

In dit tweede onderzoek ligt de nadruk niet alleen op kennis die achteraf gebruikt wordt ter verklaring van de opgevoerde aandachtspunten, maar is het eveneens de bedoeling om te achterhalen welke kennis tijdens het doornemen van de casus wordt toegepast. Dit gebeurde met behulp van de hardopdenk-methode. Deze methode houdt in dat proefpersonen tijdens het uitvoeren van een taak hardop moeten zeggen wat zij op dat moment denken. Deze methode maakt het mogelijk te achterhalen welke kennis en denkprocessen proefpersonen gebruiken bij het uitvoeren van taken (Breuker, Elshout, Van Someren \& Wielinga, 1986; Ericsson \& Simon, 1980; Hassebrock \& Prietula, 1992). In het algemeen gaat het ex hierbij vooral om te kunnen achterhalen welke kennis voor korte duur is geactiveerd en dus in het werkgeheugen zit en hoe een representatie van informatie in de casus wordt geconstrueerd. Het is echter niet zo dat alle kennis die wordt geactiveerd verbaal uitgesproken wordt (Breuker, Elshout, van Someren \& Wielinga, 1986). Volgens Ericsson en Simon (1980) zal informatie waar aandacht aan wordt besteed goed verwoord worden, maar alles wat niet in het centrum van de aandacht vait is moeilijk verwoordbaar.

$\mathrm{Er}$ is een aantal factoren dat een negatieve invloed kan uitoefenen op het hardopdenken. Ten eerste zijn er individuele verschillen in het hardop kunnen denken. De ene persoon kan beter hardop denken dan de andere (Elshout, 1976). Die verschillen verminderen vermoedelijk grotendeels als personen voor de werkelijke afname getraind worden in het hardopdenken. Een tweede negatieve factor kan zijn dat het denkproces van ervaren personen sneller verloopt, waardoor het kan voorkomen dat zij gegevens minder lang in het werkgeheugen houden. Dat kan tot gevolg hebben dat ervaren personen hun gedachten minder zullen verwoorden in hun protocollen dan de minder ervaren personen (Breuker, Elshout, Van Someren \& Wielinga, 1986). Een laatste factor die van negatieve invloed kan zijn is de taak zelf. Als het karakter van een taak zeer perceptueel, gevoelsmatig of snel is, dan is het voor de proefpersoon erg moeilijk om hardop onder woorden te brengen wat er op dat moment in het werkgeheugen zit.

Tegen bovenstaande bedenkingen van de hardopdenk-methode kan ingebracht worden dat mits er voldoende training wordt gegeven met. eenzelfde taak en deze taak informatie bevat die gemakkelijk te verwoorden 
is, de hardopdenk-methode een geschikte methode kan zijn om denkprocessen en kennistoepassing te onderzoeken.

In het eerste onderzoek (zie Hoofdstuk 3) liet de inhoud van de verklaringen zien dat de groepen nogal verschilden in de mate waarin verschillende soorten informatie aan elkaar gerelateerd werden. De vierdejaars studenten, bijvoorbeeld, relateerden überhaupt nauwelijks gegevens aan elkaar terwijl de postdoctorale NIVRA-studenten regelmatig financtële gegevens met andere financiële gegevens in verband brachten. Verder bleek dat alleen de experts financiële gegevens en informatie en kennis over de specifieke bedrijfstak aan elkaar relateerden. Als deze verschillen inderdaad bestaan, dan zullen ze met name tijdens het hardop doornemen van de casus duldelijk naar voren moeten komen. Dat wil zeggen dat de hardopdenk-protocollen van de onervaren vierdejaars studenten en de postdoctorale universitaire studenten weinig relaties tussen gegevens zullen bevatten, terwijl de meer ervaren NIVRA-studenten en de experts aanzienlijk meer gegevens aan elkaar zullen relateren. Bovendien zullen de experts andere gegevens aan elkaar relateren. $\mathrm{Zij}$ relateren immers met name înancièle gegevens aan specifieke bedrijfsinformatie, terwijl de studenten. als ze al gegevens koppeiden, financiële gegevens onderling aan elkaar relateren. De verwachting was dat als expertise-niveau toeneemt het protocol meer en andere relaties tussen gegevens bevat.

Nlet alleen de inhoud van het protocol kan interessant zijn, ook de omvang van het protocol en de tijd die de persoon nodig heeft om de casus door te nemen kan inzicht geven in de representatie van de betreffende personen. Uit eerdere studies waarbij de hardopdenk-methode gebruikt werd was naar voren gekomen dat er ook kwantitatieve verschillen in de representaties tussen de verschillende ervaringsgroepen te vinden zijn. (Boshuizen, 1989). Boshuizen vond dat de protocollen van ervaren artsen veel uitgebreider waren dan die van de minder ervaren groepen. Dit leidde tot de voorspelling dat naarmate expertise-niveau toeneemt het protocol meer informatie bevat.

Een laatste variabele die onderzocht werd in dit tweede onderzoek is de benodigde bestuderingstijd. Uit het onderzoek dat in Hoofdstuk 3 werd beschreven bleek deze variabele niet rechtlijnig samen te hangen met expertise-niveau. De resultaten suggereerden dat er een soort omgekeerd Uvormig verband bestaat tussen expertise-niveau en bestuderingstijd (al waren de verschillen niet significant). Met name de twee postdoctorale 
groepen bleken meer tijd te besteden aan het doornemen van de casus. Een mogelijke verklaring hiervoor is dat deze studenten wel veel kennis bezitten. maar dat die kennis niet zodanig is gestructureerd dat ze die kennis snel kunnen activeren. De vierdejaars studenten daarentegen bleken zeer snel te zijn, wellicht omdat zij nog maar weinig kennis hebben die kan worden geactiveerd. De experts die eveneens relatief snel waren, gebruikten bij het geven van de aandachtspunten zowel financiële gegevens en gegevens over de administratieve organisatie en de interne controle als bedrijfskenmerken. De kennis van de experts is vermoedelijk goed georganiseerd, waardoor ze snel kan worden geactiveerd en toegepast. Om de resultaten over de bestuderingstijden uit de eerste studie te bekrachtigen zullen in deze tweede studie overeenkomstige verschillen gevonden moeten worden. Er zou dus opnieuw een omgekeerd U-vormig verband moeten worden gevonden tussen expertise-niveau en de benodigde bestuderingstijd.

\section{Onderzoekmethode.}

\section{Proefpersonen}

In totaal deden 16 proefpersonen aan dit onderzoek mee: vier vierdejaars accountancy-studenten, vier postdoctorale universitaire studenten, vier postdoctorale NIVRA-studenten en vier ervaren Registeraccountants. De vierdejaars studenten hadden het doctorale accountancyprogramma bijna afgesloten. De postdoctorale universitaire studenten waren afgestudeerde economen die het accountancycurriculum aan een 'reguliere' universiteit hadden gevolgd. Zij hadden op het tijdstip van de afname van dit onderzoek gemiddeld 8 maanden praktijkervaring en hadlden het postdoctorale accountancyprogramma bijna afgerond. De postdoctorale NIVRA-studenten hadden de NIVRA-opleiding gevolgd en waren daarna ingestroomd in de postdoctorale fase van de Rijksuniversiteit Limburg. Zij hadden gemiddeld zes jaar praktijkervaring. Deze postdoctorale NIVRA-groep had het postdoctorale programma eveneens bijna afgerond. Zij dienden alleen nog een afstudeerscriptie te schrijven. De ervaren accountants, de experts, hadden gemiddeld 18 jaar praktijkervaring, waarvan een aantal jaren met bouwondernemingen.

Alle studenten werden op vrijwillige basis geworven aan de Rijksuniversiteit Limburg. De proefpersonen die ervaring hadden werkten 
allen, op één NIVRA-student na, bij één van de grote kantoren. Alle studenten hebben een vergoeding gekregen van fl. 15,--

\section{Materiaal}

De casus bestonden uit drie jaarrekeningen van verschillende bouwondernemingen 22 . De jaarrekening van een houtbedrijf 'Hout BV' was ingekort en werd gebruikt om te oefenen in het hardopdenken. De twee experimentele casus bestonden, uit de jaarrekening van 'Van Dijk Bouwgroep BV', die zowel in de woningbouw als in de utiliteitsbouw zat en de jaarrekening van 'Bagger BV', een baggermaatschappij die zich tevens bezighield met water- en wegenbouw. Alle casus bestonden uit een gedeelte beschrijvende informatie over het bedrijf, een verlies-en-winstrekening en een balans. In de beschrijvende informatie werd onder andere aangegeven. welke personen tot de directie en de raad van commissarissen behoorden. Daarnaast werd in het kort weergegeven welke ondernemingen bij het bedrijf hoorden en op welk werkveld die ondernemingen zich richten. Alle bedrijven behoorden tot de categorie 'industriële bedrijven met stukproduktie'. Toch waren de bedrijven goed te onderscheiden vanwege hun eigen karakteristieke werkzaamheden. Dit laatste is belangrijk omdat voorkomen moest worden dat de proefpersonen de inhoud van de casus gingen verwarren, doordat ze moeilijk van elkaar te onderscheiden waren (De casus zijn afgedrukt in Bijlage 3).

Het materiaal werd op het scherm van een personal computer gepresenteerd. De casus waren opgedeeld in beschrijvende en financiële informatie. De beschrijvende tekst werd per zin aangeboden en de financiële informatie, dat wil zeggen de verlies-en-winstrekening, de balans en de overige financiêle informatie, werden in drie gedeeltes gepresenteerd. De proefpersoon kon nieuwe informatie krijgen door op de return-knop te drukken. Het was niet mogelijk om terug te keren naar eerder aangeboden informatie.

Voorafgaand aan het daadwerkelijke onderzoek werd het materiaal, de taak en de procedure in een pilotstudie getest. Aan de hand daarvan werden nog enkele verbeteringen aangebracht.

${ }^{22}$ Deze casus zjn afgeleld van jaarrekeningen ult Stevens (Red.). Facts \& Figures Bouw 19911992. 


\section{Procedure}

Ook in dit onderzoek werd aan de proefpersonen duidelijk gemaakt dat de context waarin de opdracht uitgevoerd moest worden de planningsfase was (zie Hoofdstuk 1, Figuur 1.1). Het doel hiervan was dat alle proefpersonen de casus vanuit de beginfase van het controieproces bestudeerden: een fase waarin accountants over relatief weinig informatie beschikken.

Voordat de werkelijke afname begon werd aan de proefpersonen uitgelegd dat ze tijdens het doornemen van de jaarrekeningen hardop moesten denken. Verder werd hun duidelijk gemaakt hoe de informatie op het scherm zou verschijnen en hoe ze de volgende informatie op het scherm konden krijgen. Bovendien werd de proefpersonen verteld, dat er nadat de casus was doorgenomen om aandachispunten en een achterliggende verklaring gevraagd zou worden. Eerst kregen de proefpersonen de gelegenheid om met de houthandel casus te oefenen in het hardopdenken. Vervolgens werd aan de proefpersonen de mogelijkheid gegeven om vragen te stellen en kregen ze eventueel aanwijzingen over hun manier van hardopdenken. Daarna werden achtereenvolgens dle casus over 'Van Dijk Bouwgroep $B V$ ' en 'Bagger BV' afgenomen. De aandachtspunten plus verklaring naar aanleiding van 'Van Dijk Bouwgroep BV' werden direct na afloop van deze casus gevraagd. Daarna werd de casus Bagger BV' afgenomen, waarvoor dezelfde procedure gold.

De afname duurde gemiddeld cén uur.

\section{Analyse}

Een eerste kwantitatieve analyse betrof het aantal aandachtspunten waarin gerefereerd werd aan de financtêle informatie. Daarnaast werd de uitgebreidheicl van de verklaringen van de aandachtspunten geanalyseerd. De uitgebreidheid werd gemeten door het aantal informatie-eenheden te tellen. Onder informatie-eenheden moet hier worden verstaan, een financiële post of een begrip (zelfstandig naamwoord). Informatie-eenheden die meerdere keren genoemd werden bij eenzelfde aandachtspunt werden slechts één keer geteld. Informatie-eenheden die bij een ander aandachtspunt, dus in een andere context, opnieuw werden genoemd werden wel meegeteld.

Ten aanzien van de protocollen werd eveneens het aantal informatieeenheden geteld dat naar aanleiding van de financiēle informatie genoemd 
werd. Daarna werd het aantal relaties tussen die informatie-eenheden gescoord. Onder relatie dient hier verstaan te worden: het noemen en in verband brengen van twee of meerdere informatie-eenheden.

De kwalitatieve analyse van het protocol hield in, dat er naar het type relatie tussen de financiẻle informatie-eenheden werd gekeken. De geproduceercle relaties werden onderscheiden naar drie types: lokale. globale en extra globale relaties. Een lokale relatie hield in dat er posten met elkaar in verband werden gebracht die in de casus dicht blj elkaar staan, bijvoorbeeld beide informatie-eenheden staan in de balans. Een globale relatie werd gedefinieerd als een verband gelegd tussen twee of meer verschillende categorieën van financiële informatie. bljvoorbeeld informatie-eenheden uit de balans en informatie-eenheden uit de verlies-en-winstrekening. De laatste relatie, de extra globale relatie, stond voor verbanden gelegd tussen financiële informatie-eenheden en informatie-eenheden die betrekking hadden op specifleke bedrlyfskennis.

De tijd die proefpersonen gebrulkten om de flnanclële gegevens hardop door te nemen werd door de computer geregistreerd.

Alle groepsverschillen werden geanalyseerd door middel van een nonparametrische variantie-analyse.

\section{Resultaten}

\section{Aandachtspunten}

Figuur 4.1 geeft de relatie weer tussen expertise-niveau en het aantal aandachtspunten dat genoemd werd naar aanleiding van de financiële informatie. De figuur laat zien dat er een positief verband bestaat tussen expertise-niveau en het aantal financiële aandachtspunten. Het verband is echter niet significant (Chi-kwadraat $=3,54, \quad \mathrm{df}=3 . \mathrm{p}<.32$ ). De vierdejaars studenten noemden het kleinste aantal financièle aandachtspunten. De postdoctorale universitair studenten volgden met een gemiddelde van bijna drie aandachtspunten. Vervolgens noemden de postdoctorale NIVRAstudenten gemiddeld iets minder dan vier aandachtspunten en de experts gaven gemiddeld iets meer dan vier aandachtspunten. 


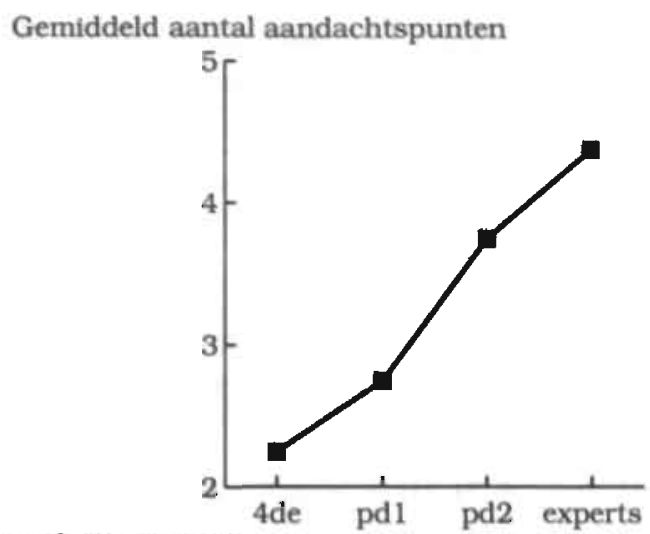

Figuur 4.1 De relatie tussen expertise-niveau en het gemiddelde aantal financiêle aandachtspunten; 4 de = vierdejaars studenten; $\mathrm{pd} 1$ = postdoctorale universitaire studenten; $\mathrm{pd} 2$ = postdoctorale NIVRA-studenten

In Figuur 4.2 wordt de relatie tussen expertise-niveau en het gemiddelde aantal informatie-eenheden per aandachtspunt getoond (Chi-kwadraat $=$ $10,0, \mathrm{df}=3, \mathrm{p}<.019)$. Uit de figuur blijkt dat de drie groepen studenten niet veel van elkaar verschilden.

Gemiddeld aantal informatie-eenheden per aandachtspunt

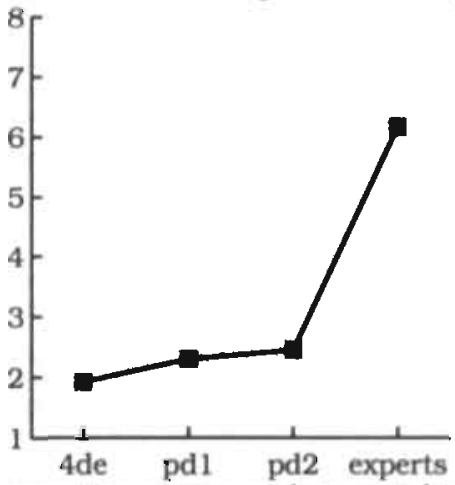

Figuur 4.2 De relatie tussen expertise-niveau en het aantal informatie-eenheden genoemd per aandachtspunt $4 \mathrm{de}=$ vierdejaars studenten; $\mathrm{pdl}=$ postdoctorale universitaire studenten; pd2 = postdoctorale NIVRA-studenten

Zoals uit Figuur 4.2 blijkt, relateerden de vierdejaars studenten lets minder dan twee informatie-eenheden aan elkaar om een aandachtspunt te verklaren. De postdoctorale universitaire groep gebruikten iets meer dan twee informatie-eenheden om hun aandachtspunt te verklaren en de postdoctorale NIVRA-groep relateerden gemiddeld 2,5 informatie-eenheden aan elkaar in de verklaring bij hun aandachtspunten. De experts noemden 
aanzienlijk meer informatie-eenheden per aandachtspunt, zij relateerden gemiddeld iets meer dan zes informatie-eenheden aan elkaar in hun verklaringen.

Om de inhoud van de aandachtspunten en de verklaringen te lllustreren zijn in Figuur 4.3 tot en met Figuur 4.6 van éên persoon uit iedere groep de aandachtspunten en verklaringen bij 'Bagger BV' verkort weergegeven.

Zoals het conceptuele netwerk in Figuur 4.3 laat zien, noemt éèn van de vierdejaars studenten ( $p$ p 4.3) drie aandachtspunten, waarvan de verklaringen bestaan ult relattes tussen twee concepten. De aandachtspunten en verklaringen van de vierdejaars student (pp 4.3) waren: 'Resultaat' is afgenomen, omdat het 'eigen vermogen' is toegenomen; 'vlottende activa' zijn fltnk gestegen en 'kortlopende schulden' zijin heel sterk gestegen; 'investeringen' waren erg toegenomen, waar waarschljnlijk de 'materlële activa' in zitten'.

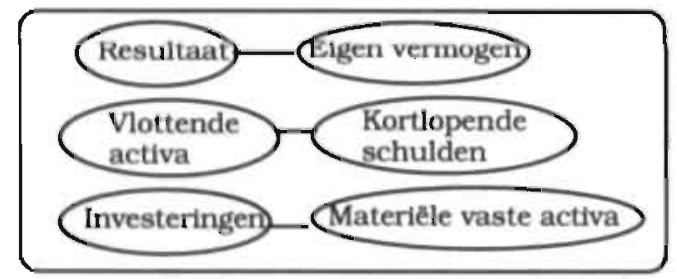

Figuur 4.3 Concepten en relaties van vierdejaars student, pp 4.3

In Figuur 4.4 worden de aandachtspunten en verklaringen van een postcloctorale universitadre student getoond. Deze student (pp pel) stelde het volgende: 'Bedriffsopbrengsten' nemen nauvelijks toe bij een stijging van aantal 'personeelsleden', terwijl 'kosten' wel toenemen; afname 'financiële vaste activa' en de 'baten' daaromtrent nemen toe, is vreemd; zijn de 'vlottende activa' wel volwaardtg alsmede de flinke stijging van de 'schulder', wat is de oorzaak, verkeert het bedriff misschien in 'betalingsproblemen'?' Deze postdoctorale universitalre student bleef vrij algemeen in zijn aandachtspunten en verklaringen en verwees niet naar aandachtspunten die specifiek. zouden kunnen gelden voor dit type bedrijf. Over het algemeen noemden de postdoctorale universitaire studenten meer aandachtspunten dan de vierdejaars studenten. 


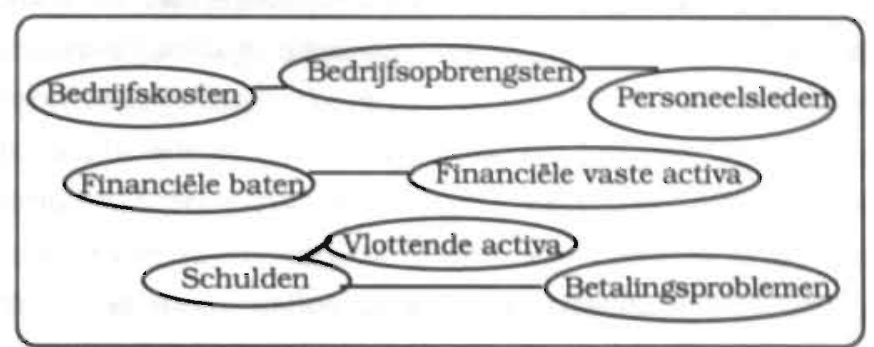

Figuur 4.4 Concepten en relaties van postdoctorale universitaire student, pp pe1

De aandachtspunten en verklaringen van een postdoctorale NIVRAstudent (pp pn2) zijn weergegeven in Figuur 4.5. Deze proefpersoon gaf de volgende aandachtspunten: 'Voor de Baggerwereld geldt specifiek een hoge post 'materiële vaste activa', waar met zeer duur 'materieel' word't gewerkt, naar kijken; 'voorraden' is een probleem by 'baggermaatschappljen' omdat het 'proces' niet goed zichtbaar is; forse post 'voorzieningen', welke voorzieningen zijn dat en zijn ze terecht getrokken?; de 'deelnemingen', zijn deze wel juist verantwoord; vreemde daling van 'personeelsleden': aantal 'baten' was hier een probleem, waarom zijn deze zo fors gestegen?' Deze NIVRA-student probeerde wel meer te redeneren vanuit kenmerken die specifiek gelden voor een Baggerbedrijf dan de student wiens protocol in Figuur 4.4 is afgedrukt

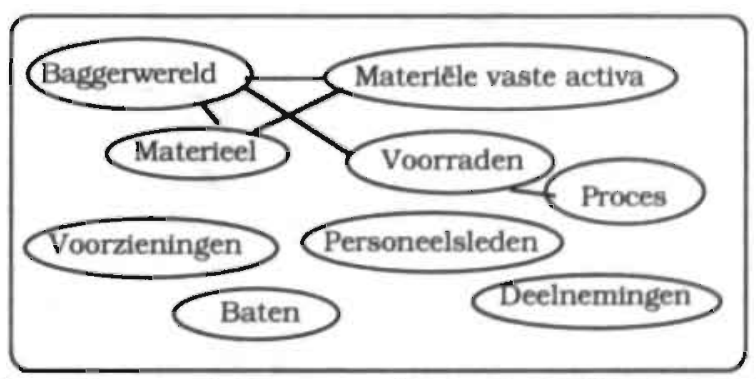

Figuur 4.5 Concepten en relaties van postdoctorale NIVRA-student, pp pn2

Gemiddeld genomen gaven de postdoctorale NIVRA-studenten meer aandachtspunten dan de twee minder ervaren groepen. Ook deze groep slaagde er echter niet in veel meer verbanden te leggen tussen informatieeenheden dan de twee minder ervaren groepen.

Figuur 4.6 laat zien hoe een expert (pp E01) zijn aandachtspunten en de daarbij horende verklaringen naar voren bracht. De opmerkingen die deze 
expert over het baggerbedrijf maakte, waren de volgende: 'Eind 88, begin 89 is er lets met de onderneming gebeurd, waarschijnlijk 'baggermaterieel' uit de vaart genomen; dat zal verklaren waarom de 'bedrijfsopbrengsten' zo zijn teruggelopen; het kan zijn dat ze vanwege de 'cyclische markt' in Nederland bepaalde werkzaamheden niet uitgevoerd krijgen; hoe zit het met de 'werkvoorraad'; of is er een stuk 'markt' weggevallen in een van de andere landen of is er een hele 'opdrachtgever' weggevallen; maar het 'bedrifsresultaat' bliff redelijk intact; ze hebben kunnen 'desinvesteren'; ze herstellen weer in 1990, ze 'investeren' weer, ze hebben een goeie 'cash-flow'; Geen echte drama's want de 'personele omvang' is redelijk intact gebleven, ja toch echt schepen uit het water; 'balanstelling' groeit gigantisch in 1990, dat zit allemaal in de 'vlottende activa'; dat moet betekenen dat ze grote 'debiteuren' hebben, ik heb niet de indruk dat het in overtollige 'liquiditeiten' zit, dan had ik meer 'interest verwacht; Grote 'debiteuren' is voor de 'Baggerbusiness' een groot gevaar, want het gaat om grote 'projecten'; Ook zou het kunnen zijn dat er belangrijke 'onderhanden werk' dus 'projecten in uitvoering' in de balans zitten; Weinig 'capaciteitsuitbreiding' en die omvang van die 'personele omvang' om het daar uit te verklaren, nee het zal iets zijn van grote 'overlopende projekten'.

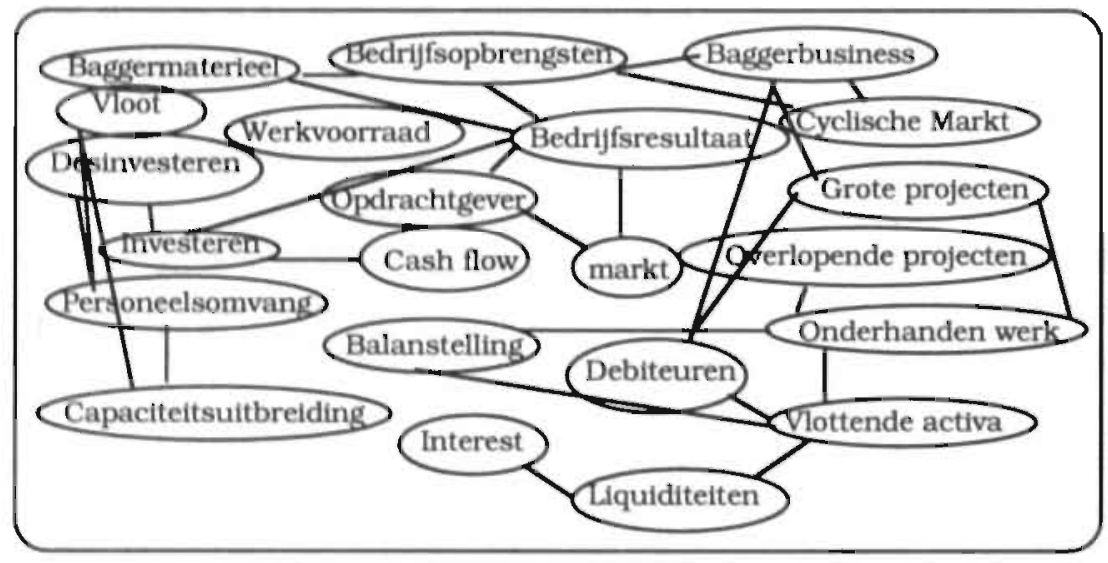

Figuur 4.6 Concepten en relaties van expert, pp E01

Over het algemeen produceerden de experts aanzienlijk: meer financiële aandachtspunten dan de andere groepen. Bovendien was het karakteristieke van experts dat ze bij het geven van een verklaring veel informatie-eenheden aan elkaar verbonden, zodat er een complex geheel tot stand kwam. Daarnaast relateerden de experts de verschillende aandachtspunten aan 
elkaar. Verder was het opvallend dat de genoemde aandachtspunten en informatie-eenheden meestal specifiek werden afgestemd op baggerbedrijven.

\section{Hardopdenkprotocollen}

Figuur 4.7 laat zien dat het aantal financièle informatie-eenheden die tijdens het hardopdenken genoemd worden significant stijgt, wanneer expertise-niveau toeneemt (Chi-kwadraat $=11.47$, df $=3, \mathrm{p}<.009$ ). In feite blijkt uit deze figuur dat er een soort tweedeling bestond tussen enerzijds de onervaren vierdejaars studenten en de weinig ervaren postdoctorale universitaire studenten en anderzijds de ervaren postdoctorale NIVRAstudenten en de experts.

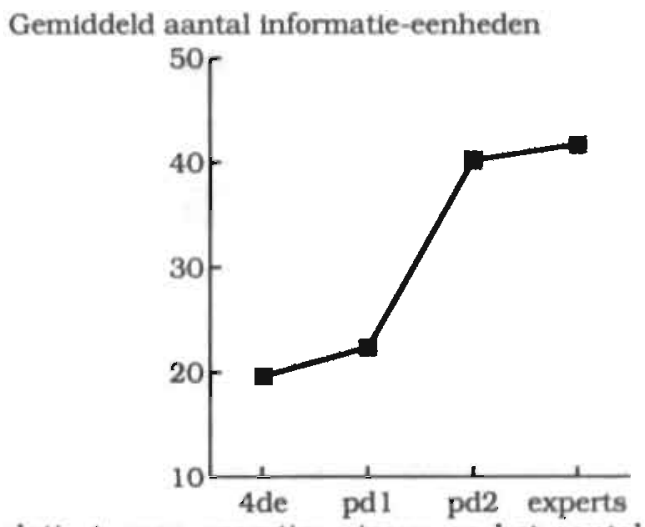

Figuur 4.7 De relatie tussen expertise-niveau en het aantal geproduceerde informatieeenheden in het hardopdenk protocol; $4 \mathrm{de}=$ vierdejaars studenten; pd $1=$ postdoctorale universitaire studenten; pd2 = postdoctorale NIVRA-studenten.

In Figuur 4.8 wordt getoond dat de groepen verder nogal verschillen in het aantal verbanden dat ze leggen tussen de informatie-eenheden (Chi-kwadraat $=12.4, \mathrm{df}=3, \mathrm{p}<.006)$. Met een toename van expertiseniveau, bleek het aantal relaties tussen de informatie-eenheden aanzienlijk te stijgen. Maar, niet alleen het aantal relaties nam toe, ook het type relatie veranderde. De resultaten gaven aan dat de vierdejaars de minste relaties legden tussen informatie-eenheden. Legden ze een relatie tussen informatieeenheden dan waren dat over het algemeen. lokale relaties, waarbij de informatie-eenheden relatief dicht bij elkaar staan. De postdoctorale universitaire studenten legden iets meer relaties tussen de verschillende 
informatie-eenheden. Ook zij beperkten zich echter grotendeels tot lokale relaties, waarbij $z i j$ af en toe een globale relatie legden. De postdoctorale NIVRA-studenten relateerden twee keer zoveel financiële informatieeenheden aan elkaar dan de andere postdoctorale groep. Daarbij was het verschil tussen de twee postdoctorale groepen hoofdzakelijk toe te schrijven aan de toename van zowel lokale als globale relaties. De NIVRA-studenten koppelden met name informatie-eenheden uit de balans en informatieeenheden uit de verlies-en-winstrekening. De experts produceerden lets meer relaties dan de NIVRA-studenten. Het opvallende was, dat experts minder lokale en globale verbanden legden dan de NIVRA-studenten, maar dat ze wel vier keer zo veel extra giobale verbanden legden dan de minder ervaren NIVRA-studenten. De experts gebruikten bij het interpreteren van de financiële informatie aanzienlijk meer specifieke bedrijfskennis.

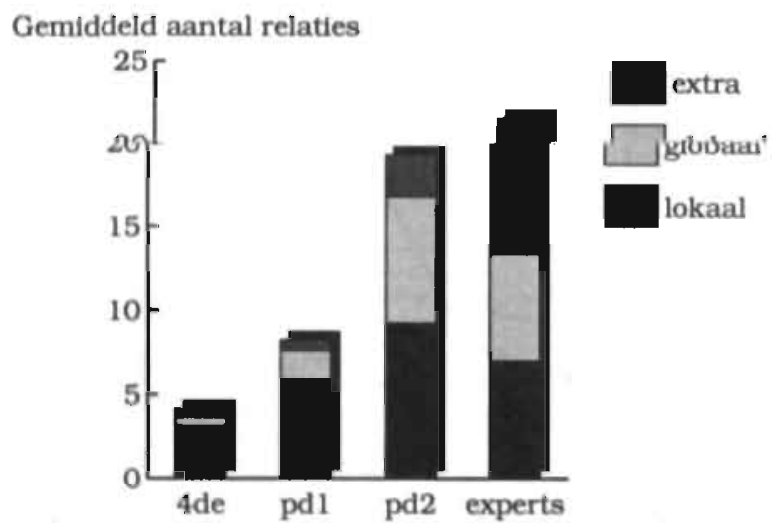

Figuur 4.8 De relatie tussen expertise-niveau en het gemiddelde aantal relaties tussen concepten in het hardopdenk protocol; $4 \mathrm{de}=$ vierdejaars studenten; pd 1 = postdoctorale universitaire studenten; pd2 = postdoctorale NIVRA-studenten; Lokaal betekent lokale relatie, globaal betekent globale relatie en extra wil zeggen een extra globale relatie

In Figuur 4.9 wordt de relatie tussen expertise-niveau en de gemiddelde benodigde bestuderingstijd gepresenteerd (Chi-kwadraat $=11,70, \mathrm{df}=3$. $\mathrm{p}<$.033). Uit deze figuur kan worden afgelezen dat de vierdejaars studenten opnieuw aanzienlijk sneller waren in het bestuderen van de financiēle informatie-eenheden dan de andere groepen. De postdoctorale NIVRAstudenten daarentegen bleken de langzaamste groep te zijn. 


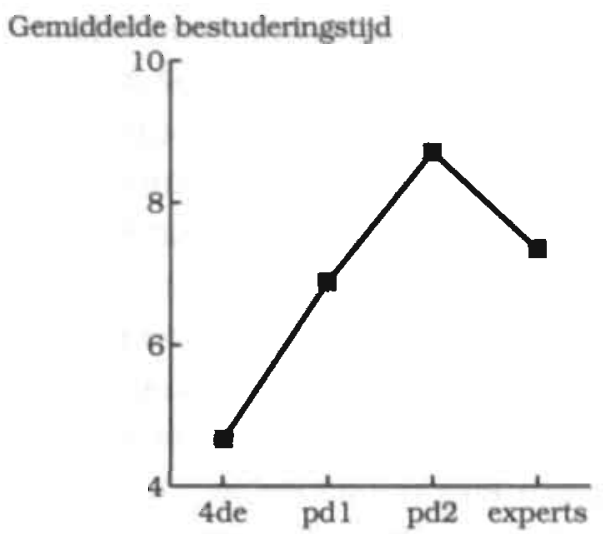

Figuur 4.9 De relatie tussen expertise-niveau en de gemiddelde bestuderingstijd in. minuten; $4 \mathrm{de}=$ vierdejaars studenten; $\mathrm{pdl}=$ postdoctorale universitaire studenten; pd2 = postdoctorale NIVRA-studenten

\section{Discussle en Conclusies}

In het hier beschreven onderzoek werd de relatie tussen expertiseniveau en de mate waarin in het bijzonder financièle kennis werd toegepast, onderzocht. Daartoe werden het aantal aandachtspunten en de uitgebreidheid van de verklaringen die gegeven werden bij deze aandachtspunten bestudeerd. Vervolgens werd nagegaan of er een verband bestaat tussen expertise-niveau en de omvang en de inhoud van de representatie die proefpersonen vormden tijdens het doornemen van de casus. De grootte van de representatie werd achterhaald door het aantal informatie-eenheden te tellen die in het protocol voorkwamen. De inhoud van de representatie werd in kaart gebracht door het aantal relaties dat werd gelegd en het type relaties die tijdens het hardopdenken werden genoemd, te tellen. Als laatste werd onderzocht of expertise-niveau en de benodigde bestuderingstijd samenhangen.

De bevindingen toonden aan, dat expertise-niveau positief gerelateerd was aan het gebrulk van financièle kennis. Met name de uitgebreidheid van de verklaringen vertoonde een significante relatie met expertise-niveau: onervaren studenten relateerden per aandachtspunt hooguit twee informatie-eenheden aan elkaar, terwijl de ervaren accountants gemiddeld 
zes informatie-eenheden per aandachtspunt aan elkaar relateerden. Een tweede resultaat liet zien, dat naarmate expertise-niveau toenam, de representatie die de groepen vormden tijdens het doornemen van de casus uitgebreider en complexer werd. Dit hield in dat de vierdejaars studenten en de postdoctorale universitaire groep een significant minder uitgebreid protocol hadden dan de NIVRA-studenten en de experts. Bovendien relateerden de onervaren vierdejaars studenten en de minder ervaren postdoctorale universitaire studenten significant minder informatie-eenheden dan de NIVRA-studenten en de experts. Verder verschilden de groepen, als ze al informatie-eenheden aan elkaar relateerden, in het type relaties dat ze legden. De vierdejaars studenten, de postdoctorale universitair studenten en de postdoctorale NIVRA-studenten relateerden voornamelijk financiële informatie-eenheden uit de balans en uit de verlies-en-winstrekening aan elkaar. De experts, daarentegen, relateerden niet alleen financiële Informatie-eenheden aan elkaar, maar koppelden eveneens financtële informatie-eenheden aan informatie-eenheden uit de bedrijfsinformatie. Verder was een opmerkelijk verschil dat bij het noemen van aandachtspunten de minder ervaren studenten meer algemene aandachtspunten noemden, terwijl de ervaren accountants het meest specifiek waren. Een laatste resultaat gaf aan dat de bestuderingstijden een significant omgekeerd U-vormig verband vertoonde met expertise-niveau. Met name de postdoctorale NIVRA-groep had significant meer tijd nodig om de informatie door te nemen en er hardop over te denken dan de andere drie groepen.

Uit deze resultaten kunnen ten aanzien van de ontwikkeling van kennisnetwerken en kennisgebruik de volgende conclusies worden getrokken:

De bevindingen geven aan dat de onervaren vierdejaars studenten een aantal flnanciêle gegevens hebben gebruikt en enkele gegevens aan elkaar relateerden die dicht bij elkaar stonden. Vergeleken met het eerste onderzoek waarin de vierdejaars studenten nauwelijks financiêle gegevens noemen bij de aandachtspunten laten de resultaten uit dit tweede onderzoek zien dat de vierdejaars studenten wel enige financiële kennis bezitten, maar dat ze niet in staat blijken te zijn om complexe relaties tussen deze financiêle gegevens te leggen. Bovendien geven de bestuderingstijden van de vierdejaars studenten aan dat ze net als in het vorige onderzoek zeer snel zijn met het doornemen van de informatie. Dit bevestigt het vermoeden dat de onervaren studenten tijdens het hardopdenken nauwelijks relaties leggen. Er kan dan 
ook geconcludeerd worden dat deze studenten wel over financièle kennis beschikken, maar dat die kennis is opgebouwd uit losse nauwelijks gerelateerde concepten. Van verbindingen naar andere conceptuele netwerken is, gezien het feit dat ze de financiēle gegevens niet in relatie brengen met bijvoorbeeld kennis over de administratieve organisatie of typische bedrijfskennis, waarschijnlijk nog geen sprake.

De postdoctorale universitaire studenten noemden iets meer financiēle gegevens en relateerden deze ook meer aan elkaar dan de vierdejaars studenten. Daarnaast trachtten deze postdoctorale studenten meer lokale relaties tussen de financiële gegevens te leggen. Deze studenten relateerden echter nauwelijks financiēle gegevens aan gegevens over de administratieve organisatie en de interne controle of aan specifieke bedrijfsinformatie. Als er al opmerkingen gemaakt werden over het type bedrijf, dan werden deze los van de financiële gegevens gemaakt. De gemiddelde bestuderingstijd van deze groep liet zien dat ze er langer over doen dan de vierdejaars studenten. Uit deze data kan geconcludeerd worden, dat het financièle kennisnetwerk van de postdoctorale universitaire studenten uitgebreider is dan het netwerk van de vierdejaars studenten. Gezien het iets grotere aantal lokale relaties die de postdoctorale universitaire studenten in het protocol weergeven bevat het netwerk van deze studenten waarschijnlijk ook iets meer verbindingen tussen de financiële concepten, dan het netwerk van de vierdejaars. Daarnaast lijkt. het erop dat er, gezien de inhoud van de protocollen en de inhoud van de verklaringen van de aandachtspunten, maar weinig verbindingen bestaan tussen financiêle kennis en andere kennis.

De meer ervaren postdoctorale NIVRA-studenten produceerden duidelijk een uitgebreider protocol dan de twee minder ervaren groepen. Bovendien relateerden deze studenten meer gegevens aan elkaar dan de minder ervaren groepen. Daarbij legden ze niet alleen meer relaties tussen dicht bij elkaar staande financiële gegevens, maar relateerden ze ook financiële gegevens uit de balans en gegevens uit de verlies-en-winstrekening aan elkaar. Deze NIVRA-studenten legden in beperkte mate meer verband tussen financiële gegevens, gegevens over de $\mathrm{AO} / \mathrm{IC}$ en gegevens over de specifleke bedrijfskennis dan de postdoctorale universitair studenten. Dit alles kan betekenen dat het financiële netwerk van deze ervaren studenten een grote hoeveelheid aan elkaar gerelateerde concepten bevat. Het verband dat deze NIVRA-studenten legden tussen financiēle gegevens en opmerkingen over de accountantscontrole geven aan dat hun financiēle kennis en hun kennis 
over controleleer in enige mate geintegreerd is. De lengte van het hardopdenk-protocol en het aantal relaties in het protocol van de NIVRAstudenten verschilde nauwelijks van die van de experts. Als gekeken wordt naar de lange bestuderingstijd van de NIVRA-groep, dan lijkt het er echter op dat de NIVRA-studenten de kennis minder goed hebben gestructureerd dan de experts. Bevestiging hiervoor blijkt onder andere uit het aantal gegevens dat per aandachtspunt genoemd wordt. Hiler zijn de NIVRA-studenten niet veel beter dan de minder ervaren studenten. De NIVRA-studenten relateren dus wel veel gegevens aan elkaar tijdens het hardopdenken, maar mogelijk vanwege het gemis aan een goede structuur in hun kennisnetwerken doen ze er vrij lang over.

De ervaren accountants, de experts, noemden meer gegevens en relateerden meer gegevens aan elkaar tijdens het hardopdenken dan alle andere groepen. Het meest opmerkelijke verschil tussen de experts en de andere groepen was dat de experts niet alleen vaker gegevens aan elkaar relateerden, maar dat er bij het leggen van die relaties aanzienlijk meer gegevens werden betrokken dan bij de andere groepen. Het. lijkt erop dat de kennisnetwerken van de experts in plaats van losstaancle concepten veel aan elkaar gerelateerde concepten bevatten. Opvallend was, dat de experts met name extra globale relaties legden tussen de gegevens tijdens het hardopdenken. Dit geeft aan dat experts de casusinformatie veelal interpreteren vanuit de specifieke kennis die ze hebben van bouw- en baggerbedrijven. Opmerkingen die tijdens het hardopdenken regelmatig gemaakt werden, waren bijvoorbeeld: Typisch een Baggerbedrijf: Competitie op de baggermarkt. en het moeilijk krijgen van orders'; 'Men zit niet in Oost- Azië, terwijl daar een. vreselijk grote markt is voor baggeren'; (pp E01); 'Geen opmerkelijke dingen tot. nu toe, dat is opmerkelijk voor een bouwbedriff: 'Baggeren is berecyclisch' ( $p$ p E02). Deze opmerkingen doen vermoeden dat de kennis van experts is georganiseerd naar specifieke bedrijfstypes. De bestuderingstijden laten zien dat de experts, die de langste protocollen hadden en de meeste relaties legden tussen de gegevens tijdens het hardopdenken in vergelijking met de andere groepen relatief erg, snel waren. Deze bevindingen, gecombineerd met het feit dat experts in hun verklaringen van de aandachtspunten gemiddeld zes gegevens verwerken, versterken het vermoeden dat de kennisnetwerken vanı experts beter zijn gestructureerd dan die van de minder ervaren groepen. 
De in dit tweede onderzoek verkregen resultaten sluiten goed aan bij de verwachtingen verwoord bij de bespreking van het netwerkmodel van kennis in Hoofdstuk 2. Wat echter bij deze twee uitgevoerde studies nog niet helemaal duidelijk is, is of de minder ervaren studenten inderdaad minder financiēle gegevens relateren omdat ze daarvan te weinig kennis hebben. Een tweede mogelijkheid is namelijk dat die studenten niet zozeer te weinig kennis bezitten, maar dat ze moeite hebben om die kennis spontaan toe te passen. Dit laatste zou een gevolg kunnen zijn van het feit dat vierdejaars studenten de context waarin de taak van de hier uitgevoerde studies zich afspeelt niet echt associēren met hun financiēle kennisbestand maar exclusief met kennis over de administratieve organisatie. Deze hypotheses werden in de laatste studie onderzocht. 


\section{Een kennistoets-studie 23}

In dit viffde hoofdstuk wordt een onderzoek beschreven waarin met behulp van een toets werd onderzocht of expertise-niveau gerelateerd is aan de toepassing van financiēle kennis. Tevens werd onderzocht of expertise-niveau samenhangt met de uitgebreidheid en complexiteit van de kennisrepresentatie van een accountancyprobleem. Daarnaast werd nagegaan of er een verband bestaat tussen expertiseniveau en bedrijfstakspecificiteit. Proefpersonen waren wederom vierdejaars studenten, postdoctorale universitair studenten, postdoctorale NIVRA-studenten en experts. De taak die de proefpersonen moesten verrichten, bestond uit het beantwoorden van uragen over causale verbanden tussen financtële gegevens uit een jaarrekening.

\section{Inleiding}

De resultaten uit de studies beschreven in de vorige hoofdstukken lieten zien dat onervaren studenten financiêle bedrijfsgegevens nauwelijks relateerden aan andere bedrijfsgegevens. Daarentegen waren de meer ervaren postdoctorale NIVRA-studenten wel in staat om bedrijfsgegevens onderling te verbinden. De aard van de gegevens die deze NIVRA-studenten aan elkaar relateerden was hoofdzakelijk financieel. De experts bleken niet alleen financiēle gegevens onderling met elkaar in verband te brengen, maar relateerden deze ook aan specifleke bedrijfskennis.

Vergelijkbare resultaten zijn verkregen in domeinen zoals natuurkunde, geneeskunde en sociale wetenschappen. In de natuurkunde en geneeskunde bleken onervaren studenten, in tegenstelling tot ervaren natuurkundigen en artsen, moeite te hebben om gegevens met elkaar in verband te brengen (Chi, Feltovich \& Glaser, 1981; Feltovich, 1981). Resultaten uit een studie uitgevoerd door Voss. Tyler en Yengo (1983) gaven aan dat ook in de sociale wetenschappen, onervaren studenten veel minder gegevens met elkaar in

${ }^{23}$ Een gedeelte van dit onderzoek is gepresenteerd tjdens de American Educational Association (AERA) meeting te San Francisco, CA, April, 1995. Educational Resources Information Center (Eric) Document Reproduction Service No. ED 385 193. Eveneens verschenen in het ujdschrift Resources in Education, december, 1995. (Vaatstra. Blommaert, Boshuizen \& Schmidt, 1995b). 
verband brachten om een argument te onderbouwen dan ervaren wetenschappers.

De tot nu toe verkregen resultaten zijn dus over het algemeen in overeenstemming met resultaten verkregen in andere domeinen. Uit het voorgaande is echter geen afdoende antwoord verkregen op de vraag of de verschillen tussen de groepen die aan de hier uitgevoerde studies hebben deelgenomen veroorzaakt worden door een gebrek aan financiële kennis of door het niet spontaan kunnen toepassen van financiële kennis in een specifieke taakomgeving, of misschien door beide.

De veronderstelling dat studenten de kennis wel bezitten, maar niet weten hoe ze die kennis spontaan moeten toepassen is gebaseerd op een discrepantie tussen verwachtingen van inhoudsdeskundige docenten en de resultaten uit de studies in Hoofdstuk 3 en 4 ten aanzien van het toepassen van financiële kennis. Volgens de docenten zouden de studenten voldoende financiële kennis uit de vakken Financiële Informatie Systemen en Externe Berichtgeving moeten hebben verworven om verbanden te kunnen leggen tussen financięle gegevens in een jaarrekening. Het verschil tussen de werkelijke prestatie en de verwachte prestaties doet echter veronderstellen dat er bij de studenten sprake is van 'inert knowledge'. Dit verschijnsel houdt in dat verworven kennis slechts wordt gebruikt in de situatie waarin het is aangeleerd.

Dit probleem is ook in andere domeinen gesignaleerd. Bransford, Sherwood, Kinzer en Hasselbring (1987) hebben bijvoorbeeld resultaten verkregen waaruit bleek dat studenten veel moeite hebben met het toepassen van eerder opgedane kennis over logaritmen op andere gebieden dan de wiskunde. Meerdere onderzoekers hebben geconstateerd dat de taakomgeving waarin studenten kennis verwerven overeen dient te komen met die waarin studenten deze kennis moeten toepassen (Bransford. Franks, Vye \& Sherwood, 1989: Cavanaugh, 1993; Feltovich, Spiro \& Coulson, 1993).

De gedachte dat een tekort aan kennis er de oorzaak van is dat minder ervaren groepen minder goed in staat zijn om financiēle kennis toe te passen dan meer ervaren groepen wordt bekrachtigd door resultaten uit een onderzoek van Christ (1993). Zij onderzocht in haar studie de relatie tussen praktijkervaring en de representatie van planning (zie voor een beschrijving van haar studie, Hoofdstuk 2). Resultaten uit dit onderzoek lieten zien dat de hoeveelheid financiêle kennis significant gerelateerd is aan praktijkervaring. Blijkbaar speelt praktijkervaring een belangrijke rol in het verkrijgen van financièle kennis. Daarnaast is het zo dat het accountancy- 
programma studenten onvoldoende kansen biedt om extra financiêle kennis op te doen dan wel reeds bestaande kennis toe te passen. Pas vanaf het cursusjaar 1994/1995 wordt er aan vierdejaars accountancystudenten van de Rijksuniversiteit Limburg een twee weken durende vaardigheidstraining aangeboden op het gebied van analyse en interpretatie van financièle gegevens. Dit is de vaardigheidstraining 'Financiêle Analyse en Cijferbeoordeling'. In deze training leren studenten een jaarrekening te interpreteren en conclusies te trekken ten aanzien van de financiêle stand van zaken van het betreffende bedrijf. Een interessante vraag is of een specifieke training in het analyseren en interpreteren van jaarrekeningen een positieve invloed heeft op het kunnen toepassen van financièle kennis. De verwachting is dat dit het geval zal zijn en dat studenten die geen specifieke training hebben gevolgd minder goed zijn in het toepassen van financielle kennis dan diegene die wel zo'n training hebben gevolgd. Gezien de consistente resultaten van Christ (1993) en die beschreven in de studies in Hoofdstuk 3 en 4 is de verwachting echter dat deze getrainde vierdejaars groep door het ontbreken van praktijkervaring niettemin minder goed presteert dan groepen die wel praktijkervaring hebben.

Om te achterhalen of taakomgeving dan wel gebrek aan kennis de oorzaak van de resultaten uit de twee voorgaande studies is, werd in dit derde onderzoek de accountancytaak losgelaten. Er werd een toets afgenomen met gerichte vragen over causale verbanden tussen gegevens in een financiële jaarrekening. Als er sprake is van 'inert knowledge' bij studenten, dan zullen de minder ervaren proefpersonen, dus ook de studenten zonder specifieke training, de vragen op de toets net zo goed moeten maken als de meer ervaren proefpersonen. Als het een kwestle van feitelijke training is om financiēle kennis goed te kunnen toepassen, dan zullen vierdejaars studenten die de voornoemde vaardigheidstraining hebben gevolgd net zo goed moeten presteren op de kennistoets als proefpersonen met praktijkervaring. Gezien de bevindingen van Christ (1993) en de resultaten verkregen in de studies die beschreven staan in Hoofdstuk 3 en 4 van dit proefschrift wordt echter verwacht dat expertise-niveau opnieuw positief gerelateerd zal zijn aan de toepassing van financiêle kennis.

Resultaten uit een onderzoek van Voss, Tyler en Yengo (1983) en uit de studies beschreven in Hoofdstuk 3 en 4 duidden erop dat experts hun kennis specifieker toespitsen op het type bedrijf. Zowel in het eerste onderzoek als in het tweede bleken experts regelmatig opmerkingen te maken die aangaven dat ze redeneerden vanuit typische bedrijfscategorieên. Voorbeelden daarvan 
waren opmerkingen als "Dat geldt voor bouwbedrijven in het algemeen" of "Dat. is niet normaal voor een baggermaatschappiy". In dit derde onderzoek wordt onderzocht of expertise-niveau wederom positief samenhangt met het gebrulk van bedrijfstakspecifieke begrippen. De verwachting is dat naarmate expertise-niveau toeneent, het aantal begrippen dat specifiek over de bouw gaat eveneens toeneemt.

In de studies beschreven in het derde en vierde hoofdstuk bleek de bestuderingstijd een omgekeerd U-vormig verband te hebben met expertiseniveau. Vierdejaars studenten en experts waren aanzienlijk sneller dan de twee tussenliggende postdoctorale groepen. Met name de postdoctorale NIVRA-groep was trager dan de andere groepen. De achterliggende verklaring die daarvoor gegeven werd was dat de onervaren studenten waarschijnlijk zo snel reageren omdat hun kennis viij beperkt is, waardoor ze vrij weinig concepten kunnen activeren. Van de vierdejaars studenten met training wordt verwacht dat ze meer financiēle kennis hebben dan de vierdejaars studenten zonder training, waardoor ze meer tijd nodig zullen hebben voor de toets. De experts konden de informatie zo snel verwerken, omdat hun kennis beter is gestructureerd dan die van de andere groepen. De postdoctorale NIVRA-studenten waren trager dan de postdoctorale universitaire studenten omdat de NIVRA-studenten aanzienlijk meer concepten en meer aan elkaar gerelateerde concepten hebben opgeslagen in hun kennisnetwerken. De vraag was dus, of de gevonden tijdsverschllen bij het maken van deze toets eveneens voorkomen. Dus, vormt expertise-niveau een omgekeerd $\mathrm{U}$-vormig verband met de tijd waarin de toets wordt gemaakt?

\section{Onderzoekmethode}

\section{Proefpersonen}

In totaal namen 106 proefpersonen aan het onderzoek deel: 41 vierdejaars accountancystudenten; 29 postdoctorale universitaire accountancystudenten; 22 postdoctorale NIVRA-studenten en 14 ervaren accountants. De vierdejaars studenten hadden het doctoraal programma accountancy bijna afgesloten. Van deze vierdejaars studenten hadden 17 studenten een specifieke financiêle vaardigheidstraining gevolgd. Alle vierdejaars studenten studeerden aan de Rijksuniversiteit Limburg. De postdoctorale universitaire studenten waren afgestudeerde economen die eerder het accountancycurriculum hadden gevolgd. Zij hadden op het tijdstip van 
de afname van dit onderzoek gemiddeld 1,5 jaar praktijkervaring en hadden het postdoctorale accountancyprogramma bijna afgerond. De postdoctorale NIVRA-studenten hadden de NIVRA-opleiding gevolgd en waren daarna ingestroomd in de postdoctorale fase aan de universiteit. Zij hadden gemiddeld zeven jaar praktijkervaring. Deze postdoctorale NIVRA-groep had het postdoctorale programma eveneens bijna afgerond, zij dienden alleen nog een afstudeerscriptie te schrijven. Beide postdoctorale groepen waren afkomstig van de Rijksuniversiteit Limburg en van de Universiteit van Amsterdam. De ervaren accountants waren werkzaam bij éên van de grote kantoren en hadden gemiddeld 21,5 jaar praktijkervaring.

De studenten kregen een vergoeding van $\mathrm{fl}$. 15,--

\section{Materiaal}

Het materiaal dat de proefpersonen werd aangeboden, bestond uit de casus 'Bagger BV' die ook in het tweede onderzoek gebrulkt was, tien vragen over causale relaties tussen financiēle gegevens in deze casus en een evaluatieve vragenlijst. De causale vragen zijn mede ontwikkeld op basis van de opmerkingen die experts tijdens het hardopdenken in het tweede onderzoek hebben gemaakt. Een deskundige op het gebled van jaarrekeningen en boekhouden heeft bij de opmerkingen uit de hardopdenkprotocollen van de experts een antwoordmodel samengesteld. In Bijlage 3 is de casus 'Bagger BV' weergegeven en in Bijlage 4 staan de vragen met de bijbehorende modelantwoorden.

De vragen zijn 'gepretest' door een aantal medewerkers, van de Vakgroep Berichtgeving van de Rijksuniversiteit Limburg. Daarna is een aantal verbeteringen aangebracht. Vervolgens heeft de afname plaatsgevonden.

\section{Procedure}

De tcets werd door de proefpersonen thuis gemaakt. De instructie die aan de proefpersonen. werd gegeven was dat ze de vragen zo uitgebreid en specifiek mogelijk moesten beantwoorden. Verder werd hun verzocht geen studieboeken en dergelijke te raadplegen. Ze dienden zelf de tijd bij te houden die ze nodig hadden om de vragen te maken.

Het kostte de meeste proefpersonen ongeveer éẻn uur om de toets te maken. 


\section{Analyse}

De toetsscore werd bepaald door de antwoorden te vergelijken met de modelantwoorden (zie Bijlage 4). Het aantal punten dat iemand kon behalen was afhankelijk van het aantal correcte deelantwoorden dat gegeven werd. Per vraag konden maximaal 10 punten worden behaald. De maximumscore over de gehele toets was dus 100. De toetsscore gaf aan in welke mate lemand de vragen juist en volledig had beantwoord.

Een tweede analyse betrof het aantal begrippen die spectfiek gelden voor de controle van een bouwbedrijf. Ter verduldelijking, begrippen zoals bijvoorbeeld 'debiteuren", 'voorraad' en 'vlottende activa' zljn van toepassing op allerlei types bedrijven, terwijl begrippen als: 'onderhanden werk'. 'langlopende projecten', 'gefactureerde termijnen', 'opgeleverde werken', specifiek gelden voor bedrijven die met langdurige projecten te maken hebben, zoals bouwbedrijven.

De tijd die lemand nodig had om de toets te maken werd door de proefpersoon zelf geregistreerd. Dit deed hij/zij door aan het begin van de toets, na het lezen van de casus maar voor vraag 1 , de begintijd in te vullen en aan het einde van de toets, na het beantwoorden van vraag 10 maar voor de evaluatie, de eindtijd in te vullen.

De data werden geanalyseerd door middel van variantie-analyse. Om specifleke groepsverschillen te achterhalen werden bovendien paarsgewijze vergelijkingen met de Scheffé F-test uitgevoerd. Twee personen hebben de antwoorden afzonderlijk beoordeeld; één persoon was niet op de hoogte van de onderzoeksvragen. De beoordelingsovereenstemmings-coëfficient was .75. Voor de statistische analyse van de toetsscore werd het gemiddelde van de twee beoordelaars gebrulkt.

\section{Resultaten}

Figuur 5.1 laat zien dat er significante verschillen bestaan tussen de groepen ten aanzien van de volledigheid waarmee de toets gemaakt is $(\mathrm{F}(4,101)=9,55, \mathrm{p}<.0002)$. Ten eerste bleken de vierdejaars studenten die geen specifieke training hadden gevolgd in het interpreteren van financiēle gegevens het minst volledig te zijn. Hun toetsscores verschilden significant van de postdoctorale universitaire en de postdoctorale NIVRA-studenten. Daarentegen bleken de vierdejaars studenten die wel een specifieke training 
hadden gevolgd in het interpreteren van financiêle gegevens bijna net zo goed te presteren als de postdoctorale universitair studenten. De volledigheid van deze getrainde vierdejaars studenten vertoonde geen significante verschillen met die van de andere groepen. De postdoctorale NIVRA-studenten bleken de meest volledige antwoorden te hebben. Onverwacht was het resultaat dat de experts minder volledig antwoordden dan de vierdejaars studenten met training en de postdoctorale universitaire studenten.

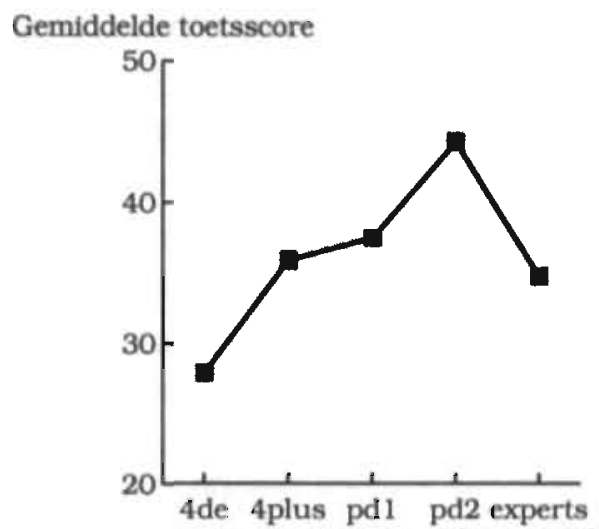

Figuur 5.1 De gemiddelde toetsscore per groep; 4 de = vierdejaars studenten: 4 plus = vierdejaars studenten met training; pd1 = postdoctorale universitair studenten; pd2 = postdoctorale NIVRA-studenten.

Om een beter beeld te krijgen van de antwoorden die gegeven zijn op de toets worden in Figuur 5.2 tot en met 5.6 voorbeelden gegeven die representatief zijn voor de vier deelnemende groepen. Het antwoord in deze voorbeelden behoort bij de vraag: Wat kan je zeggen van de fluctuaties in het balanstotaal van 1988 tot 1992 in relatie tot de fluctuaties in de omzet van 1988 tot 1992 ?

In Figuur 5.2 wordt het antwoord van de vierdejaars student zonder training (pp 2) gegeven. Deze figuur laat zlen dat deze student volstaat met het beschrijven van het gevraagde verband. Ook andere niet getraindle vierdejaars studenten gaven soortgelijke antwoorden. Ze gebruikten veelal de financièle posten uit de vraag en gebruikten weinig andere gegevens om de vraag te beantwoorden.

Omzet. neemt toe bij een daling van het balnnototal (89-90)

Gelijkblijvend balenatotan bij een dalende omzet (90-91).

Grote stijging balanstotanl bij lichte stijging omzet (91-92)

Figuur 5.2 Antwoord van vierdejaars student zonder training. pp 2 
Figuur 5.3 laat zien dat de vierdejaars student die een financiële training heeft gevolgd, (pp 104), zelf een aantal financiële begrippen toevoegde, namelijk 'resultaat' en 'activa'. Deze student beschreef daarnaast niet alleen wat in de financiële jaarrekening staat, maar trachtte ook een oorzaak te geven voor de fluctuatie in het balanstotaal en omzet. Andere studenten die de vaardigheidstraining gevolgd hebben gaven overeenkomstige antwoorden. Net als pp 104 gebruikten zij meer gegevens uit de jaarrekening bij het antwoord dan de vierdejaars studenten zonder training.

Ondanks het feit dat het balanstotad van 1989 op 1990 fors is gedaald is het
rewultant lets gestegen. De omzetdaling kwam pas een jaar later. In 1992 stijgt
het balanstotaal weer sterk, maar de omzet slechts beperkt. Waarschijnlijk
loopt de omzetontwlkkellng achter bij het inkrimpen en uitbreiden van de
activa.

Figuur 5.3 Antwoord van vierdejaars student met training. pp 104

In Figuur 5.4 staat het antwoord van een postdoctorale universitaire student (pp 39). Het antwoord van deze proefpersoon bevatte meer verschillende financièle gegevens dan het antwoord in. Figuur 5.3. Toch is de causale redenering van deze postdoctorale student onvolledig. Hij noemde slechts de financięle gegevens uit 1990 en 1991 en liet bljvoorbeeld de gegevens uit 1992 ongemoeid. Over het algemeen lagen de antwoorden van de postdoctorale universitaire studenten wat volledigheid betreft tussen de onervaren en ervaren studenten in.

Balanstotal neemt in ' 90 enorm af: met name schulden. Hierdoor minder
vermogen beschikbaar voor activitelten. waardoor omzet in ' 91 enorm daalt.
Zle ook desinvestering en daling vlottende active.

Figuur 5.4 Antwoord van postdoctorale universitaire student, pp 39

Het antwoord van een postdoctorale NIVRA-student (pp 46) dat in Figuur 5.5 is gepresenteerd, laat zien dat deze student de vraag zeer uitgebreid en volledig beantwoordde. Bovendien laat Figuur 5.5 zien dat deze NIVRA-student zijn antwoord veel meer toespitste op het type bedrijf dan de minder ervaren studenten. Dit bleek vooral uit de begrippen die deze student gebruikte, zoals 'onderhanden werk' en 'oplevering van werken'. De antwoorden van deze meer ervaren studenten geven aan dat ze de financiēle posten uit de jaarrekening in de context van het bedrijf interpreteerden. 
De afname van het balanstotaal en bedrifsopbrengsten in 1990 resp. 1991 is bij uraag 1 en 2 al verklaard. In 1992 neemt het balanstotaal fors toe $t$. o. $v$. 1991. Een mogelijke oorzaak is een toename van de post onderhanden werken onder de vlottende activa. Ingeval de winstneming op onderhanden werken pas geschiedt na oplevering van het werk, staat tegenover de toename van de onderhanden werken pas na 1992 de realisatie, zodat dan pas een omzetstijging tot stand zal komen.

Figuur 5.5 Antwoord van postdoctorale NIVRA-student, pp 46

In Figuur 5.6 wordt het antwoord van. een expert (pp 83) getoond. Het antwoord laat zien dat ook experts de financiēle gegevens interpreteerden binnen het kader van bouwbedrijven. Dat bleek bijvoorbeeld uit genoemde begrippen als 'onderhanden werk' en 'langlopende projecten'. Verder laat het voorbeeld zien dat het antwoord van deze expert minder uitgebreid en volledig was dan dat van de NIVRA-studenten. Ook de andere experts gaven minder volledige antwoorden dan de NIVRA-studenten.

Steeds verdere afname van de boekwaarde van de materiële vaste activa door
afname investering. Langlopende projecten waarvan de onderhanden
werken worden geactiveerd en eventuele termljnen worden gepassiveerd. Als
omzet wordt waarschijnlijk verantwoord de opgeleverde werken.

Figuur 5.6 Antwoord van expert, pp 83

In Figuur 5.7 wordt het verband geschetst tussen expertise-niveau en het aantal concepten dat voor het type bedrijf specifiek was. Dit verband bleek significant te $x i j n(F(4,101)=9,38, p<.0002)$. De vierdejaars studenten met en zonder training gebruikten de minste bouwbegrippen in hun antwoorden. De postdoctorale universitaire studenten bleken gemiddeld slechts 0,2 bouwbegrippen per antwoord te gebruiken. Dit aantal verschilde significant van het aantal bouwbegrippen dat de experts noemden. De postdoctorale NIVRA-studenten gebruikten gemiddeld 0,45 bouwbegrippen in hun antwoorden. Zij verschilden significant van de twee vierdejaars groepen. De experts gebruikten de meeste bouwbegrippen in hun antwoorden. Zij verschilden eveneens significant van de twee vierdejaars groepen. 


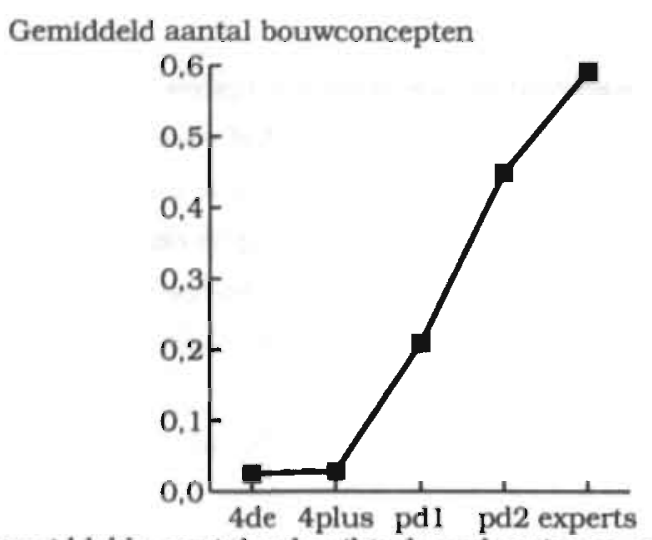

Figuur 5.7 Het gemiddelde aantal gebruikte bouwbegrippen per groep; 4de = vierdejaars studenten; 4 pius = vierdejaars studenten met training: $p d \bar{l}=$ postdoctorale universitair studenten: $\mathrm{pd} 2$ = postdoctorale NIVRA-studenten

In Figuur 5.8 wordt de gemiddelde tijd weergegeven die de groepen nodig hadden om de toets te maken. De resultaten gaven aan dat er een groot verschil bestond tussen de groepen $(\mathrm{F}(4,84)=2,90, \mathrm{p}<.027)$. De experts bleken de minste tijd te hebben gebruikt. Een aantal experts had slechts dertig minuten nodig om de toets te maken. Zij verschilden significant van de vierdejaars studenten die de vaardigheidstraining hadden gevolgd. Deze vierdejaars studenten waren het traagst in het maken van de toets. Verder vertoonden geen van de groepen significante verschillen ten opzichte van elkaar.

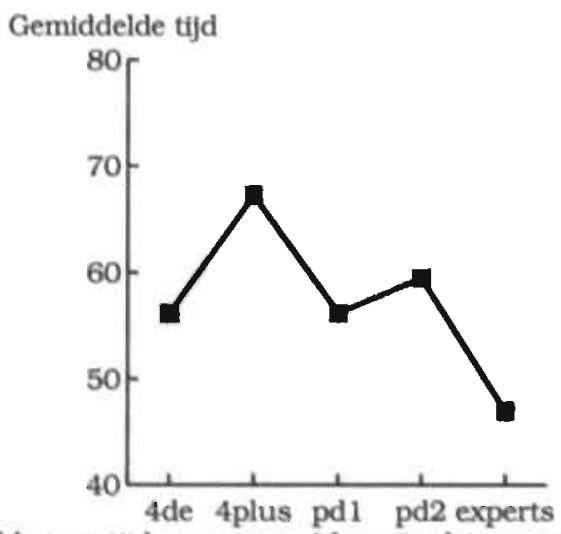

Figuur 5.8 De gemiddelde toetstijd per groep; 4 de = vierdejaars studenten; 4 plus = vierdejaars studenten met training; pdl = postdoctorale universitair studenten; pd2 $=$ postdoctorale NIVRA-studenten 


\section{Discussie en Conclusies}

In dit laatste onderzoek werd onderzocht of de verkregen resultaten uit de vorige twee studies veroorzaakt worden door moeilijkheden met het toepassen van kennis vanwege de taakomgeving dan wel door een gebrek aan kennis. Er werd nagegaan of er zonder een specifieke accountancytaak een positief verband bestaat tussen expertise-niveau en toepassing van financiële kennis. Verder werd onderzocht of de relatie tussen expertiseniveau en bedrijfstakspecificiteit positief is. Als laatste werd de relatie tussen expertise-niveau en de benodigde bestuderingstijd onderzocht.

De bevindingen uit dit laatste onderzoek bevestigen voor een deel de resultaten uit de studies die beschreven zijn in de Hoofdstukken 3 en 4 van dit proefschrift. Dat wil zeggen: zoals verwacht presteerden de vierdejaars studenten die geen training hadden gehad minder goed dan de vierdejaars studenten, die wel een training hadden gevolgd. Op hun beurt presteerde deze laatste groep slechter dan de postdoctorale studenten. Wat echter niet voorspeld was, was dat het toetsresultaat van de experts lager uitviel dan dat van de NIVRA-studenten. Deze tegenvallende prestatie kan een aantal oorzaken hebben. Ten eerste geeft de bestuderingstijd aan, dat de experts de toets zeer snel hebben gemaakt. Zij bleken veel sneller te zijn dan de andere groepen. Bovendien bleek uit de data dat de experts in hun antwoorden significant vaker naar andere vragen verwezen dan de vierdejaars studenten en de postdoctorale universitaire studenten $(\mathrm{F}(4,101)=5,33, \mathrm{p}<.0007)$. Dit geeft enerzijds aan dat de experts de begrippen uit de verschillende vragen combineren. maar anderzijds laat het zien dat de experts de toets zo snel mogelijk probeerden te maken. Een tweede oorzaak kan liggen in het feit dat het antwoordmodel slechts algemene begrippen bevatte die op ieder bedrijf van toepassing zijn (zie bijlage 4). Uit Figuur 5.7 bleek dat experts juist zeer bedrijfsspecifieke begrippen gebruikten bij het beantwoorden van de vragen. Om te achterhalen of het algemene antwoordmodel een negatieve invloed heeft gehad op de toetsscores van de experts zijn de antwoorden van de experts door een derde persoon beoordeeld. Deze beoordelaar had de opdracht na te gaan of de gebruikte begrippen synoniemen waren van de begrippen uit de modelantwoorden. Ook na de beoordeling van deze persoon bleven de toetsscores van de experts echter relatief laag. De experts waren dus gewoonweg minder volledig geweest in het beantwoorden van de toets dan verwacht. Een derde mogelijkheid waarom de toetsscores van de experts zo laag uitgevallen zijn, kan zijn dat de experts veel beknopte antwoorden 
hebben gegeven. Aangezien het er bij deze toets juist om ging zo uitgebreid en volledig mogelijk te antwoorden, is het geven van korte antwoorden. in het. nadeel van de experts geweest. Waarschijnlijk zouden de antwoorden meer uitgebreid zijn geweest als de toets mondeling was afgenomen, waardoor het mogelijk is naar aanleiding van de gegeven antwoorden door te vragen. Resultaten uit met name het medische domein hebben aangetoond dat experts informatie zowel beknopt als uitgebreid kunnen representeren (Schmidt \& Boshuizen, 1993). Dit zou kunnen betekenen dat experts, mits er nadrukkelijk om gevraagd is, hun kennis wel kunnen ontvouwen zodat er een uitgebreid antwoord komt. Een laatste verklaring voor de prestaties van de experts zou kunnen zijn, dat deze minder goed presteren op gedetallleerde vragen dan de postdoctorale NIVRA-studenten, omdat de NIVRA-studenten als controleleiders in de praktijk regelmatig op zoek gaan naar gedetallleerde oorzaken van gesignaleerde fouten en onregeimatigheden, terwijl de ervaren accountants als medewerker of vennoot de mogelijke fouten en onregelmatigheden voornamelijk signaleren. Dit sluit aan bij de eerdere bevindingen dat de experts beter presteerden als er om aandachtspunten gevraagd werd. Deze meer globale taak slult wellicht beter aan bij de werkzaamheden die medewerkers en vennoten in de praktijk uitvoeren.

Het gebruik van specifieke begrippen die gerelateerd zijn aan het controleren van een bouwonderneming bleek significant samen te hangen met expertise-niveau. De experts en de postdoctorale NIVRA-studenten bleken significant meer van dit type begrippen toe te passen dan de beide vierdejaars groepen. De postdoctorale universitaire studenten gebruikten iets meer van dit soort begrippen dan de onervaren vierdejaars studenten, maar pasten deze begrippen veel minder toe dan de postdoctorale NIVRAstudenten. De experts noemden de meeste bouwbegrippen bij het beantwoorden van de vragen. Deze verschillen laten duidelijk zien dat er een positief verband bestaat tussen ervaring en specificiteit. Dat wil zeggen: hoe meer praktijkervaring iemand heeft des te specifieker zijn de antwoorden gericht op het type bedrijf.

Uit de tijd die men nodig had om de vragen te beantwoorden kan worden afgeleid dat de vierdejaars, studenten met training aanzienlijk meer tijd nodig hadden dan de andere groepen. In vergelijking met de vierdejaars studenten zonder training zijn ze gemiddeld tien minuten langer bezig. De postdoctorale universitaire studenten die eveneens geen specifieke training in het eerder gevolgde accountancydoctoraal hebben gevolgd doen er net zo lang over om de toets te maken als de vierdejaars zonder training. Toch is 
hun toetsscore iets hoger dan die van studenten met training. De postdoctorale NIVRA-studenten hadden iets meer tijd nodig voor het beantwoorden van de vragen dan de vierdejaars groep zonder training en de postdoctorale universitaire studenten. Dit tijdsverschil kan voor een groot deel verklaard worden door de uitgebreide antwoorden. De experts, zoals gezegd, hadden de minste tijd nodig om de toets te maken. Bij deze groep zijn het juist de beknopte antwoorden en de vele verwijzingen naar antwoorden op andere vragen die voor de snelle tijd zorgden.

Een resultaat dat overeenkwam met de verwachting dat een specifieke training een positieve invloed zou hebben op het toepassen van financiële kennis, bleek uit het verschil in volledigheid tussen de vierdejaars studenten met en zonder specifieke training. De vierdejaars studenten zonder training presteerden aanzienlijk minder dan de vierdejaars groep met training. Bij de vierdejaars studenten zonder training werden regelmatig antwoorden gegeven als 'er is geen relatie tussen die gegevens' of werden de gegevens uit de vraag slechts herhaald. De vierdejaars studenten met training trachtten, ondanks dat ze het goede antwoord vaak niet wisten, toch een aantal gegevens bij de vraag te betrekken.

De hier gepresenteerdie studie was mede opgezet om te achterhalen of de oorzaak van de resultaten beschreven in Hoofdstuk 3 en 4 in de taakomgeving dan wel in een tekort aan financiële kennis ligt. $\mathrm{Er}$ werdl geredeneerd dat wanneer de accountancy-taakomgeving een belangrijke oorzaak is voor het feit dat de minder ervaren studenten nauwelijks financiële kennis toepassen, de groepen niet meer zouden moeten verschillen in de wijze waarop ze financiële kennis toepassen wanneer de accountancytaakomgeving is weggelaten. Aangezien de hier verkregen resultaten aangeven dat, er nog steeds verschillen tussen de groepen bestaan, gaat deze verklaring niet op. Een tekort aan kennis werd als tweede mogelijke oorzaak gezien voor de resultaten beschreven in Hoofdstuk 3 en 4. Als gemis aan kennis de oorzaak is dan, zo werd gesteld, zou een training waarin het toepassen van financièle kennis centraal staat een positief effect moeten hebben op de prestaties. De hier verkregen resultaten laten zien dat vierdejaars accountancystudenten die een specifieke training hebben gevolgd inderdaad beter presteren dan de vierdejaars studenten zonder training. Bovendien presteren ze bijna net zo goed als de postdoctorale universitair studenten die gemiddeld 1,5 jaar ervaring hebben. Het niveau van de NIVRA studenten is voor de vierdejaars studenten met training echter niet 
haalbaar. De financièle kennis verbetert dus wel behoorlijk na een vaardigheidstraining op het gebied van financiēle analyse, maar wordt toch voornamelijk verworven door praktijkervaring.

De ontwikkeling van kennis in het accountancydomein kan dus als volgt worden voorgesteld: de vierdejaars studenten die geen training hebben gevolgd, blijken in dit derde onderzoek net als in het tweede onderzoek moeite te hebben financiële gegevens aan elkaar te relateren. Dit geeft aan dat ze misschien wel enige financiēle kennis bezitten, maar dat tussen de aanwezige financiêle concepten nauwelijks verbindingen bestaan. Ondanks het feit dat deze studenten in de evaluatie aangeven dat ze de toets moeilijk vonden, spenderen ze erg weinig tijd aan de toets. Dit zou erop kunnen duiden dat deze studenten of de toets niet belangrijk vinden of de financiēle gegevens niet kunnen relateren aan elkaar. Aangezien de studenten in de evaluatue aangeven dat ze het interpreteren van financièle gegevens belangrijk tot zeer belangrijk voor de praktijk vinden ligt het voor de hand te concluderen dat het financiële kennisnetwerk van deze studenten uit concepten bestaat die niet sterk aan elkaar gerelateerd zijn.

De vierdejaars studenten die een specifleke cursus in het interpreteren van financièle gegevens hebben gevolgd, blijken hun financiële kennis beter toe te kunnen passen. Deze studenten geven betere antwoorden en relateren meer gegevens aan elkaar dan de andere vierdejaars groep. Om gegevens aan elkaar te kunnen relateren hebben ze wel aanzienlijk meer tijd nodig dan de vierdejaars studenten zonder training. Het gegeven dat deze studenten veel ujd nodig hebben om de toets te maken geeft aan dat ze moeite hebben met het vinden van de relevante concepten en met het aan elkaar relateren van deze concepten. Deze studenten geven in de evaluatie aan dat ze de taak qua moeilijkheidsniveau redelijk vinden. Dus, ondanks het feit dat ze langer over de toets doen hebben ze het idee dat ze in staat zijn financielle gegevens aan elkaar te relateren. Het feit dat deze studenten met training beter in staat zijn om financiële kennis toe te passen zou erop kunnen duiden dat ze meer financielle kennis bezitten dan de vierdejaars studenten zonder training. De oorzaak van de langere tijdsduur die deze getrainde studenten nodig hebben. ligt vermoedelijk in het feit dat het financièle kennisnetwerk veel aan elkaar gerelateerde concepten bevat die nog niet zo vaak zijn geactiveerd, waardoor het maken van de toets veel inspanning vergt en dus langer duurt.

De postdoctorale universitaire studenten hebben een significant hogere toetsscore dan de vierdejaars zonder training. Ten opzichte van de vierde- 
jaars studenten met training scoren ze iets beter op de toets. De postdoctorale universitaire studenten die gemiddeld 1,5 jaar ervaring hebben passen hun kennis bovendien specifieker toe op de casus dan de onervaren vierdejaars studenten. Verder zijn de postdoctorale universitaire studenten bij het maken van de toets net zo snel als de vierdejaars studenten die geen training hadden gevolgd. Wat betreft. de evaluatie van de moeilijkheidsgraad van de taak geven de postdoctorale universitaire studenten aan dat ze het een redelijk moeilijke taak vinden. Ze verwachten wel dat ze middelmatig gescoord hebben op de toets. Uit deze data kan geconcludeerd worden dat het financieel conceptueel netwerk van de postdoctorale universitaire studenten uitgebreider en complexer is dan het netwerk van de vierdejaars studenten. Gezien. het feit dat ze de toets redelijk snel hebben gemaakt kan gesteld worden dat ze de opgeslagen kennis vaker gebruikt hebben, waardoor ze die kennis sneller kunnen activeren.

De postdoctorale NIVRA-studenten hebben de hoogste toetsscore. Ze hadden wel meer tijd nodig om de toets te maken. Verder geven de NIVRAstudenten specifiekere antwoorden door de redenering toe te spitsen op het type bedrijf. Ten aanzien van het gemiddelde aantal begrippen dat speciflek slaat op bouwbedrijven noemen de NIVRA-studenten twee keer zoveel begrippen als de andere postdoctorale studenten. Het zlet ernaar uit dat het kennisnetwerk met financièle concepten van deze ervaren studenten aanzienlijk uitgebreider, complexer en specifieker is dan het netwerk van de andere studenten.

De experts zijn, zoals gezegd, minder volledig, in het beantwoorden van de vragen dan de postdoctorale NIVRA-studenten. Bovendien hebben zij de toets in een zeer snelle tijd gemaakt. Verder is gebleken dat zil in vergelijking met de minder ervaren groepen relatief veel begrippen noemen die specifiek slaan op bouwbedrijven. Experts interpreteren financièle informatie dus voor een groot gedeelte vanuit de specifieke kennis die ze hebben van bouw- en baggerbedrijven. De kennis van experts is dan ook vermoedelijk georganiseerd naar bedrijfstypes. Vanuit deze bedrijfstypes kunnen ze hun financiële concepten snel aan andere gegevens relateren. 
$-122=$ 


\section{Samenvatting, Conclusies \& Implicaties}

In dit laatste hoofdstuk zijn de voorafgaande hoofdstukken nog eens kort samengevat. Vervolgens worden conclusies getrokken en komen beperkingen aan bod die voor de hier uitgevoerde studies gelden. Dit hoofdstuk eindigt met een aantal praktische implicaties voor de accountancy-opleiding en accountancypraktijk.

\section{Samenvatting}

Het eerste gedeelte van Hoofdstuk 1 handelt over de ontwikkeling van het accountancyberoep. De werkzaamheden van accountants bestonden in die beginjaren voornamelijk uit taken als: de inrichting van boekhoudingen, het bijwerken van gebrekkige administraties en het opmaken van balans, winst- en liquidatierekeningen. Tegenwoordig is de controle van de Jaarrekening één van de hoofdtaken van accountants. Daarnaast controleren ze inzake fusies en overnames en leveren ze advies op het gebled van organisatiestructuur, informatievoorziening, etc. In dit proefschrift staat de algemene controle van de jaarrekening centraal. Daarbij moet opgemerkt worden dat met name de eerste fase van het controleproces, de planningsfase, de context is van waaruit deelnemers aan de hier uitgevoerde studies hebben gehandeld.

Naast het beroep komen in dit hoofdstuk eveneens de belangrijkste opleidings-instituten en organisaties aan bod die de accountants begin deze eeuw vertegenwoordigden en opleidden. Vanaf het begin was het NIVA ${ }^{24}$ één van de grootste beroepsorganisaties op het gebled van de accountancy. Academische accountancy-opleidingen kwamen vanaf 1915 op gang en in 1927 werd een aparte vereniging voor academisch opgeleide accountants, de VAGA 25 , opgericht. Met de aanvaarding van de Wet op de Registeraccountants (WRA) in 1962 werden NIVA- en VAGA-leden als gelijkwaardig erkend en konden beide zich vanaf 1967 inschrijven in het Accountantsregister van de nieuwe accountancy-organisatie: het NIVRA26.

\footnotetext{
24 Het Nederlands Instituut voor Accountants.

25 Vereniging voor Academisch Gevormde Accountants.

26 Het Nederlands Instituut voor Registeraccountants.
} 
In het tweede gedeelte van het eerste hoofdstuk staan de verschillende opleidings-mogelijkheden voor Registeraccountant beschreven. De huidige opleidingstrajecten zijn: de deelopleiding aan de HEAO, de deeltijdopleiding aan de NIVRA-Nijenrode Universiteit en de full-time opleiding aan de reguliere universiteiten. De opleiding aan de HEAO behelst een deel van de opleiding tot Registeraccountant. Studenten die hier afstuderen vervolgen de opleiding bij de NIVRA-Nijenrode universiteit of stromen in het doctoraalprogramma van een reguliere universiteit in. De NIVRA-Nijenrode Universiteit verzorgt een deeltijdopleiding, waarbij studenten gemiddeld acht Jaar één dag in de week naar de opleiding komen. Deze studenten zijn van het begin af aan werkzaam in de praktijk. Studenten die het. traject aan een 'reguliere' universiteit volgen moeten eerst het doctoraalprogramma afsluiten alvorens ze in de praktijk gaan werken. In de WRA was vastgelegd dat de NIVRA-Nijenrode-studenten (toen NIVRA-studenten) en de universitaire studenten ${ }^{27}$ dezelfde landelijke examens dienden te maken. Een overzicht van de onderwijsprogramma's in Hoofdstuk 1 laat dan ook zien dat de inhoud van de vakken aan de twee opleidingen vrijwel identiek is. Wat echter een essentieel verschil tussen de NIVRA-Nijenrode opleiding en de reguliere universitaire opleidingen is, is het aantal jaren praktijkervaring dat studenten hebben. Zo hebben NIVRA-Nijenrode studenten gemiddeld zeven tot negen jaar praktijkervaring op het moment van inschrijven in het Register, terwijl universitaire studenten meestal één tot twee jaar in de praktijk hebben gewerkt voordat ze Registeraccountant zijn. Aangezien beide groepen op het moment van inschrijving dezelfde titel hanteren en dus als gelijkwaardig moeten worden beschouwd, kan de vraag worden gesteld of accountancystudenten die vanaf de start van de opleiding zowel theoretische kennis als praktijkervaring opdoen wel als gelijkwaardig moeten worden beschouwd aan universitaire studenten die pas in het postdoctorale programma praktijksituaties tegenkomen. Op basis van literatuuronderzoek en empirische studies is in dit proefschrift getracht zicht te krijgen op de invloed van praktijkervaring en de ontwikkeling van expertise.

In Hoofdstuk 2 is nagegaan wat in de literatuur tot nu toe bekend is over de invloed van praktijkervaring en de ontwikkeling van expertise op het terrein van de accountancy. Het hoofdstuk begint met een uiteenzetting van

$27 \mathrm{Er}$ wordt in dit proefschrift gesproken over universitaire studenten wanneer studenten het accountancyprogramma aan een 'reguliere' universiteit hebben gevolgd. Deze naam is gekozen bij] gebrek aan een beter alternatief. 
wat in dit proefschrift onder expertise zal worden verstaan. Daarna worden achtereenvolgens de volgende onderzoeksstromingen besproken: studies vanuit Brunswik's Lensmodel, studies naar heuristieken, studies naar het cognitieve redeneerproces en studies naar de relatie tussen expertise-niveau en kennis en kennisstructuur.

Onderzoekers die accountancy-expertise vanuit het Brunswik's Lensmodel bestudeerden, probeerden te achterhalen of er een positief verband bestond tussen mate van expertise-niveau en een aantal aspecten die belangrijk worden geacht voor het accountantsoordeel. De aspecten die deze onderzoekers voornamelijk in relatie brachten met expertise waren: consensus, stabiliteit, accuratesse en zelfinzicht. Resultaten lieten zien dat de voorspelde expertiseverschillen in consensus, stabiliteit en inzicht in de meeste Lens-studies nauwelijks te vinden waren (voor een overzicht van de studies, zie Hoofdstuk 2, Tabel 2.1). Een positieve ultzondering was de accuratesse van het uiteindelijke oordeel. Echter waardoor die kwaliteitsverschillen in de uiteindelijke beoordeling werden veroorzaakt, was op basis van de Lensstudies nauwelijks te beantwoorden.

In de jaren tachtig werd er voor het eerst aandacht besteed aan de relatie tussen expertise-niveau en het gebrulk van heuristieken. Frederick en Libby (1986) hebben een aantal studies uitgevoerd waarin werd onderzocht of ет een verband bestond tussen mate van expertise-niveau en het gebruik van de 'representativiteltsheuristiek'. Deze heuristiek houdt In dat er een oordeel wordt gevormd op basis van de overeenkomst van lets of iemand met een prototypisch voorbeeld daarvan. De resultaten uit de experimenten bevestigden de voorspellingen van Frederick en Libby. De experts beoordeelden nieuwe informatie op basis van overeenkomsten met prototypische gevallen, terwijl de onervaren accountants dat niet deden.

Eveneens in de jaren tachtig kwam er belangstelling voor het cognitieve recleneerproces dat voorafgaat aan het uiteindelijke oordeel van de accountant. Grondleggers van deze stroming waren Newell en Simon (1972). Gebaseerd op het probleemoplossingsmodel van Newell en Simon hebben onder andere Einhorn en Hogarth (1981) een model ontworpen waarin het redeneerproces in vier fases was opgedeeld: informatieverwerving, evaluatie, actie en feedback. Geïnspireerd door deze procesmatige aanpak van redeneren zijn een aantal expertisestudies in de accountancy gedaan. Bouwman $(1978,1984)$ bijvoorbeeld heeft onderzoek verricht naar verschillen tussen het redeneerproces van ervaren accountants en die van onervaren 
accountancy studenten bij het maken van een financiële analyse. Biggs, Mock en Watkins (1988) onderzochten of er verschillen bestaan tussen ervaren en onervaren accountants ten aanzien van het redeneerproces tijdens het voorbereiden van een controleprogramma. Ook Libby en Frederick (1990) en Bedard en Biggs (1991) hebben studies uitgevoerd waarin de relatie tussen expertise-niveau en verschillen in het redeneerproces is bestudeerd. Uit de resultaten van deze onderzoeken kwam naar voren dat er verschillen bestaan in de wijze waarop ervaren en onervaren accountants redeneren. De verkregen resultaten uit deze redeneerstudies waren echter niet eenduidig. Zo vond Bouwman kwalitatieve verschillen tussen de groepen in de redeneerfase en niet in de informatieverwervingsfase, terwijl Biggs et al. (1988) juist wel verschillen in de informatieverwervingsfase vonden en niet in de redeneerfase (voor een literatuuroverzicht zie Hoofdstuk 2, Tabel 2.2).

Begin jaren tachtig is in verschillende domeinen onderzoek uitgevoerd naar de relatie tussen expertise-niveau en verschillen in kennis en kennisstructuur. Deze onderzoeken leidden tot een aantal consistente resultaten (Chi \& Glaser, 1988; Ericsson \& Smith, 1991; Glaser, 1986). Zo bleek dat experts meer domeinkennis bezitten dan niet-experts en was de domeinkennis van experts ook anders georganiseerd dan de domeinkennis van nietexperts. Een model dat de verkregen resultaten grotendeels kan verklaren is het model waarbij kennis als een conceptueel kennisnetwerk wordt gerepresenteerd. In zo'n conceptueel netwerkmodel geven concepten de eigenschappen van een idee of begrip weer en representeren de verbindingen tussen de concepten de relatie tussen de begrippen of ideeën (zie Hoofdstuk 2. Figuur 2.1).

In het accountancydomein is men vanaf midden jaren tachtig de relatie tussen expertise-niveau en verschillen in kennis en kennisstructuur gaan onderzoeken. De hoeveelheid kennis en de structuur van de kennis zijn door Choo en Trotman (1991), Christ (1993). Frederick (1991), Frederick, HelmanHoffman en Libby (1994), Moeckel (1990), Rennile (1991) en Tubbs (1992) onderzocht (voor een overzicht, zie Hoofdstuk 2. Tabel 2.3). De hoeveelheid kennis en de organisatie van kennis is in het accountancydomein veelal onderzocht met behulp van de 'recall' methode. Bij deze methode wordt ervan uitgegaan dat personen die een uitgebreid kennisnetwerk bezitten en daardoor meer mogelijkheden hebben om nieuwe informatie te koppelen aan bestaande concepten, beter in staat zijn om nieuwe relevante informatie te onthouden dan personen met een minder uitgebreid kennisnetwerk. Experts 
van wie verwacht wordt dat ze meer domeinkennis hebben zullen zich dan meer moeten kunnen herinneren van nieuwe relevante informatie dan beginners. Inderdaad bleken accountancy-experts een uitgebreidere 'recall' te hebben dan beginnende accountants. Daarnaast produceerden experts meer betekenisvolle 'clusters' in de 'recall' dan niet-experts. Een bevestiging voor het feit dat experts over schemata 28 beschikken bleek uit de bevindingen dat ervaren accountants meer reconstructiefouten makkten, meer inferenties produceerden in de 'recall' en vaker aandacht schonken aan gegevens die afweken van bestaande schemata. Onderzoek van Christ (1993) liet zien dat experts niet alleen meer informatie onthielden en de 'recall' anders hadden georganiseerd, maar dat experts ook andersoortige informatie onthielden dan beginners. Experts bleken bijvoorbeeld significant meer financiële informatie te onthouden dan beginners, terwijl er ten aanzien van informatie over interne controle procedures geen verschillen tussen de groepen bestonden. Helaas is er op het gebied van de accountancy geen vervolgonderzoek uitgevoerd waarin de relatie tussen expertise-niveau en soort kennis nader is onderzocht.

In de afgelopen tien jaar zijn er dus een aantal eenduidige resultaten verkregen op het gebled van accountancy-expertise. Zo hebben alle studies die de relatíe tussen accountancy-expertise-niveau en de hoeveelheid en organisatie van de 'recall' bestudeerden een positief verband gevonden. Daamaast geeft de studie van Christ (1993) aan dat er sprake is van een relatie tussen expertise-niveau en soort kennis. $\mathrm{Er}$ is dus maar éen studie waarin expertise-niveau in verband is gebracht met soort kennis. Verder is niet of nauwelijks gekeken naar de wijze waarop deze kennis zich ontwikkelt, van onervaren accountants, zoals doctorale studenten naai gemiddeld ervaren accountants, zoals postdoctorale NIVRA-studenten. Daamaast zijn er in geen van de uitgevoerde studies tijdmetingen zijn gedaan. Hierdoor kan de vraag ' of ervaren accountants relevante informatie sneller verwerken dan beginners' niet worden beantwoord. Bovendien hebben onderzoekers in slechts twee studies waarin de relatie tussen expertise-niveau en kennis is bestudeerd, een poging gedaan om te onderzoeken of expertise-niveau gerelateerd is aan de specifieke toepassing van aanwezige kennis. Een laatste punt van kritiek betreft de relatief geringe aandacht die is besteed aan

28 Een schema is een semantische representatie van generieke kennis over gebeurtenissen, scenario's, acties en objecten (Anderson, 1995). 
praktische suggesties voor de accountancy-opleiding en de accountancypraktijk.

Om de hier geconstateerde tekortkomingen aan te vullen zijn in dit. proefschrift een drietal empirische studies uitgevoerd waarin de volgende onderzoeksvragen zijn onderzocht. Ten eerste: wat is de invloed van praktijkervaring op de ontwikkeling van een conceptueel kennisnetwerk? Ten tweede: bezitten ervaren accountants meer domeinkennis dan minder ervaren accountants en komen ze daardoor tot betere en meer specifieke oplossingen dan minder ervaren accountants? Ten derde: beschikken ervaren. accountants over andersoortige kennis dan minder ervaren accountants? En tenslotte: verwerken ervaren accountants relevante informatie sneller dan minder ervaren accountants?

\section{Recall-studte}

In de eerste studie, gerapporteerd in Hoofdstuk 3, is onderzocht of expertise-niveau en de toepassing van kennis positief gerelateerd zijn. Met andere woorden of ervaren accountants beter zijn in het signaleren van. aandachtspunten bij een bedrijf dan minder ervaren accountants. Daarnaast werd nagegaan of expertise-niveau samenhangt met de omvang en inhoud van de kennisrepresentatie. Dat wil zeggen, bezitten ervaren accountants meer en andersoortige kennis dan minder ervaren accountants? Tenslotte is onderzocht of expertise-niveau gerelateerd is aan de benodigde bestuderingstijd. Aan het onderzoek hebben vijf groepen deelgenomen van elk acht personen die verschilden wat betreft hun expertise-niveau. De procedure was als volgt: proefpersonen kregen drie casus te lezen waarvan ze na het lezen dienden aan te geven welke gegevens (aandachtspunten) uit de casus van belang zouden kunnen zijn voor een uit te voeren accountantscontrole. Verder werd om een verklaring voor de keuze van deze: gegevens gevraagd. Een laatste opdracht bestond uit het opschrijven van datgene wat ze zich nog konden herinneren van de casus (de recall). Resultaten uit dit eerste onderzoek gaven aan dat de groepen nauwelijks verschilden in de mate waarin zij gebrulk maken van kennis over de administratieve organisatie en de interne controle. Daarentegen verschilden de groepen wel aanzienlijk in het gebruik van financièle kennis. De onervaren vierdejaars studenten gebruikten bijvoorbeeld uitsluitend kennis van de administratieve organisatie en de interne controle en nauwelijks financiēle kennis. Ook de 
postdoctorale universitaire studenten schonken de meeste aandacht aan de administratieve organisatie en de interne controle. De meer ervaren postdoctorale NIVRA-studenten daarentegen gebruikten meer financiéle kennis en trachtten bij het interpreteren van de financiêle posten informatie over de administratieve organisatie en de interne controle te betrekken. De experts gebruikten de meeste financiële kennis en probeerden kennis van de administratieve organisatie en de interne controle en typische bedrijfskennis aan de flnanciẽle kennis te relateren. Deze verschillen bleken niet te leiden tot verschillen in de letterlijke 'recall' van de aangeboden informatie. Wel verschilden de groepen significant voor wat betreft het aantal inferenties dat in de 'recall' werd geproduceerd. Met name de postdoctorale NIVRAstudenten en de experts produceerden significant meer inferenties in de 'recall' dan de minder ervaren groepen. Deze inferenties werden voomamelijk gemaakt ten aanzien van de financlële informatie. De tjd die de groepen nodig hadden om alle gegevens te verwerken hing omgekeerd U-vormig sannen met expertise-niveau. Dat wil zeggen dat de vierdejaars studenten en de experts sneller waren dan de twee postdoctorale groepen.

De onderzoeksvragen kunnen dus gedeeltelijk positief worden beantwoord. Zo blijkt er een significante relatie te bestaan tussen expertiseniveau en toepassing van kennis. Of deze relatie samenhangt met hoeveelheid domeinkennis is vooralsnog niet duldelijk. Enerzijds geeft de hoeveelheld letterlijke 'recall' aan dat er wellicht geen verband tussen expertise-niveau en de hoeveelheid domeinkennis bestaat, terwijl het aantal inferenties wel een significant verband tussen expertise-niveau en de hoeveelheid domeinkennis lat zien. De verwachting dat ervaren accountants sneller zijn dan minder ervaren accountants wordt eveneens niet helemaal bevestigd. Een laatste bevinding toont aan dat er signiflcante expertise-verschillen bestaan in de soort kennis die gebrulkt wordt. De minder ervaren accountants blijken nauwelijks financiële kennis bij het beoordelen van een bedrijf te gebruiken, terwijl de ervaren accountants dat wel doen. Daarnaast laten de verklaringen zien dat ervaren accountants veel bedrijfstakspecifieke kennis gebruiken.

Een vervolgstudie is opgezet om te onderzoeken of de in deze eerste studie verkregen resultaten consistent zijn. Daarbij is een andere, meer directe, onderzoekmethode gebruikt. 


\section{Hardopdenk-studie}

In het tweede onderzoek (zie Hoofdstuk 4) werd met behulp van een hardopdenk-methode onderzocht of de in de eerste studie geconstateerde relatie tussen expertise-niveau en de toepassing van financiële kennis kon worden bevestigd. Tevens werd opnieuw bestudeerd of expertise-niveau en de uitgebreidheid van de kennisrepresentatie zijn gerelateerd. Ook werd het verband tussen expertise-niveau en complexiteit van de kennisrepresentatie onderzocht. Aan het hler gepresenteerde onderzoek hebben vier groepen bestaand uit vier personen deelgenomen. De groepen varieerden wat betreft expertise-niveau. Proefpersonen kregen twee casus aangeboden die ze hardopdenkend dienden door te nemen. Net als in. de eerste studie werd hun achteraf gevraagd welke gegevens ze van belang achtten voor de uit te voeren controle (aandachtspunten) en waarom. Resultaten uit dit onderzoek lieten eveneens zlen dat er grote verschillen tussen de groepen bestonden. De onervaren vierdejaars studenten bleken bijvoorbeeld gemiddeld slechts twee financièle aandachtspunten aan te geven, terwijl de experts gemiddeld vijf. aandachtspunten signaleerden. Daarnaast verschilden de groepen aanzienlijk voor wat betreft de achterliggende verklaringen bij de aandachtspunten. De verkiaringen van de vierdejaars studenten, de postdoctorale universitaire en de NIVRA-studenten waren minder uitgebreid dan die van de experts. De verklaringen van de studenten bevatten gemiddeld slechts twee gerelateerde gegevens, terwljl die van de experts gemiddeld zes gerelateerde gegevens bevatten. Verder lieten de achterliggende verklaringen zien dat naarmate expertise-niveau toenam, de inhoud van deze verklaringen steeds specifieker naar het type bedrijf werd toegeschreven. Het bijbehorende hardopdenk-protocol van de onervaren vierdejaars studenten en de postdoctorale universitaire studenten bevatte significant minder gegevens dan het protocol van de meer ervaren NIVRA-studenten en de experts. Ook het aantal en het soort relaties dat werd gelegd tussen de gegevens tijdens het hardopdenken verschilde significant. De vierdejaars studenten relateerden slechts financiēle gegevens aan elkaar die dicht bij elkaar in de aangeboden informatie voorkwamen. De postdoctorale universitaire studenten relateerden iets meer financièle gegevens aan elkaar. Een klein aantal daarvan bestond uit relaties tussen gegevens die verder uit elkaar waren geplaatst. De postdoctorale NIVRA-studenten relateerden financiēle gegevens twee keer zo vaak aan elkaar dan de postdoctorale universitaire studenten. 
Bovendien relateerden deze NIVRA-studenten net zo vaak dicht bij elkaar geplaatste als verder uit elkaar geplaatste financièle gegevens aan elkaar. Er werd door deze NIVRA-studenten zelfs een paar keer een relatie gelegd tussen de financièle gegevens en de bedrijfstakgerelateerde informatie. De experts relateerden financièle gegevens niet vaker aan elkaar dan de postdoctorale NIVRA-studenten. Wel verschilde het type relatie van de experts behoorlijk van het type van de NIVRA-studenten. De experts relateerden voornamelijk financiële informatie en bedrijfsinformatie aan elkaar, terwijl de NIVRAstudenten meestal financiële gegevens onderling trachtten te relateren. De tijd die werd uitgetrokken om de financiële informatie hardopdenkend door te nemen hing, net als in de eerste studie, omgekeerd U-vormig samen met het expertise-niveau. De vierdejaars studenten bleken het snelst te zijn terwijl de postdoctorale NIVRA-studenten de meeste bestuderingstijd nodig hadden.

Deze studie laat dus zien, dat ervaren accountants niet alleen meer financiële kennis bezitten dan minder ervaren accountants, maar dat ze ook meer bedrijfstakspecifieke kennis bezitten dan minder ervaren accountants. verder maken de ervaren accountants net als in de eerste studie veel beter gebruik van hun kennis. Alleen zij zijn in staat om de verschillende soorten kennis met elkaar te integreren bij het beoordelen van een jaarrekening. De relatie tussen bestuderingstijd en expertise-niveau is van dezelfde aard als in de eerste studie: omgekeerd U-vormig.

Wat na deze tweede studie nog steeds niet helemaal duidelijk is, is of de minder ervaren studenten Inderdaad minder financiële kennis hebben of dat die studenten niet zozeer te weinig kennis bezitten, maar dat ze moeite hebben om die kennis spontaan toe te passen. Dit laatste verschijnsel, 'inert knowledge', zou een gevolg kunnen zijn van het feit dat vierdejaars studenten de context waarin de taak van de hier uitgevoerde studies zich afspeelt niet echt associēren met hun financiële kennisbestand maar exclusief met kennis over de administratieve organisatie. In de volgende en tevens laatste studie is nader onderzocht welke van deze twee verklaringen opgaat.

\section{Kennistoets-studie}

In dit laatste onderzoek (Hoofdstuk 5) werd nagegaan of de verkregen resultaten uit de vorige twee studies veroorzaakt worden door een gebrek aan. 
financiële kennis dan wel door moeilijkheden met het toepassen van financièle kennis vanwege de taakomgeving. Verder werd onderzocht of het. reeds eerder geconstateerde verband tussen expertise-niveau en bedrijfstakspecifleke verwijzingen opnieuw positief is. Als laatste werd de relatie tussen expertise-niveau en de benodigde bestuderingstijd onderzocht. Proefpersonen. waren wederom vierdejaars studenten, postdoctorale universitair studenten, postdoctorale NIVRA-studenten en experts. In totaal namen 106 proefpersonen deel aan dit onderzoek. De taak die de proefpersonen moesten verrichten bestond uit vragen over causale verbanden tussen financiële gegevens uit een jaarrekening. Resultaten uit dit derde onderzoek gaven aan dat ook op deze toets onervaren studenten moeite hadden met het toepassen van financiêle kennis. Wanneer onervaren vierdejaars studenten een specifieke training in het analyseren van financiêle informatie hadden gevolgd presteerden zij aanmerkelijk beter op de toets dan de vierdejaars studenten die geen training hebben gevolgd. De postdoctorale universitaire studenten behaalden een hogere toetsscore dan de beide vierdejaars groepen. De NIVRA-studenten presteerden beter op de toets dan alle andere groepen. Deze laatste groep relateerde de meeste gegevens aan elkaar bij het beantwoorden van de vragen. De experts tenslotte, waren minder volledig in hun antwoorden dan was verwacht. Zij gaven zeer beknopte antwoorden en verwezen in hun antwoord veel vaker naar andere vragen dan de minder ervaren groepen. Het leek erop dat de experts de toets niet helemaal serieus hadden gemaakt en daardoor laag scoorden op de toets. Bevestiging voor dit vermoeden kwam naar voren uit de tijd die men aan de toets besteed had. De experts hadden zo'n 30 tot 45 minuten aan de toets besteed. De vierdejaars studenten zonder training en de postdoctorale universitaire studenten deden er iets minder dan 60 minuten over. De postdoctorale NIVRA-studenten hadden gemiddeld zestig minuten nodig om de toets te maken. De vierdejaars studenten die de training in financiêle analyse hadden gevolgd waren het langzaamst, zij deden er bijna zeventig minuten over. Uit een specifieke analyse van de inhoud van de antwoorden bleek dat met toenemende praktijkervaring het aantal begrippen die specifiek betrekking hebben op het type bedrijf aanzienlijk toenam. 


\section{Conclusies}

De in dit proefschrift gepresenteerde studies hebben dus een aantal belangrijke expertise-verschillen aangetoond. De gestelde onderzoeksvragen kunnen merendeels positief beantwoord worden. Experts bleken bijvoorbeeld in de eerste twee studies tot betere en meer specifieke oplossingen te komen dan niet-experts. Resultaten van de derde studie lieten zien dat de experts niet beter maar wel specifieker antwoordden. Ook gebruikten experts andere informatie dan niet-experts. Experts integreerden veel vaker financiële kennis, kennis over de administratieve organisatie en de interne controle en bedrijfskennis dan de niet-experts. Daarnaast bleek de bestuderingstijd omgekeerd U-vormig samen te hangen met expertise-niveau. Experts bleken minder snel te zijn in het verwerken van relevante informatie dan onervaren vierdejaars studenten maar waren consequent sneller dan postdoctorale studenten.

Uit de bevindingen van de drie uitgevoerde studies kunnen ten aanzien van de onderzoeksvraag betreffende de ontwikkeling van kennis de volgencle conclusies worden getrokken. De vierdejaars studenten blijken in het eerste onderzoek enkel kennis van de administratieve organisatie en de interne controle $(\mathrm{AO} / \mathrm{IC})$ toe te passen. Dat doen ze zelfs iets beter dan de meer ervaren groepen. Uit het tweede onderzoek blijkt dat deze studenten wel enigszins in staat zijn financiële kennis toe te passen, maar blijken ze weinig financiële gegevens met elkaar in verband te brengen en noemen ze vooral losstaande gegevens. Bovendien leggen zij geen verband tussen de financiêle informatie en informatie over de AO/IC. Uit het derde onderzoek blijkt tenslotte dat als de vierdejaars studenten expliciet om financiële relaties gevraagd wordt, ze wel enig verband kunnen leggen tussen de verschillende financiële gegevens. De prestaties van de vierdejaars studenten ten aanzien van financiële kennis is echter minder dan men op grond van de opleiding zou verwachten. Uit de genoemde resultaten kan geconcludeerd worden dat het $\mathrm{AO} / \mathrm{IC}-k e n n i s n e t w e r k$ van deze vierdejaars studenten veel concepten bevat met veel verbindingen ertussen, maar dat het financieel conceptueel kennisnetwerk minder uitgebreid en complex is. Verder geven de resultaten aan dat er tussen het AO/IC-netwerk en het financlële netwerk nauwelijks verbindingen bestaan.

Een specifieke cursus in het interpreteren van financiēle gegevens heeft als resultaat dat de vierdejaars studenten beter in staat zijn hun financiēle 
kennis te gebruiken. Dat deze studenten de financiële gegevens beter toepassen duidt erop dat mede door de financiēle vaardigheidstraining het financiële kennisnetwerk uitgebreider en complexer is geworden. Het netwerk. bevat mogelijk meer financiële concepten en verbindingen dan het netwerk. van de vierdejaars studenten zonder training. Dat deze getrainde studenten relatief veel tijd nodig hebben om de toets te maken kan veroorzaakt zijn doordat de concepten en verbindingen in het financiële kennisnetwerk van. deze vierdejaars studenten nog niet zo vaak zijn geactiveerd, waardoor het moeite en tijd kost in het kennisnetwerk de juiste concepten te vinden.

De resultaten uit het eerste onderzoek toonden aan dat de postdoctorale universitaire studenten ten aanzien van het gebruik van hun kennis van de $\mathrm{AO} / \mathrm{IC}$ weinig verschilden van de vierdejaars studenten. Het $\mathrm{AO} / \mathrm{IC}-$ kennisnetwerk van de postdoctorale universitaire studenten lijkt dus qua inhoud op het netwerk van de vierdejaars studenten. Wel relateren deze postdoctorale universitaire studenten meer financiële gegevens aan elkaar dan de vierdejaars studenten. Uit het feit dat ze in alle drie studies ook meer ujd gebruiken om de informatie door te nemen dan de vierdejaars studenten kan afgeleld worden dat hun financiêle kennisnetwerk meer concepten en onderlinge verbindingen bevat. Dit kennisnetwerk lijkt echter nog weinig geactiveerd; vandaar dat relatief veel tijd besteed werd. Verder laten het eerste en tweede onderzoek zien dat ook deze weinig ervaren studenten relatief weinig financiēle informatie aan $\mathrm{AO} / \mathrm{IC}$-informatie relateren. Mogelijk bestaan er ook bij deze studenten weinig verbindingen tussen een financieel kennisnetwerk en een AO/IC-kennisnetwerk. Het derde onderzoek liet zien dat de postdoctorale universitaire studenten af en toe concepten gebruikten die specifiek gelden voor bouwbedrijven. Hieruit kan afgeleid worden dat deze studenten na ruim een jaar werkzaam geweest te zijn in de praktijk al proberen om $\mathrm{AO} / \mathrm{IC}-$ kennis en financièle kennis te integreren met: specifieke bedrijfskennis.

De postdoctorale NIVRA-studenten produceerden significant meer inferenties dan de minder ervaren studenten. Deze inferenties bleken voornamelijk gemaakt te worden bij de aangeboden financiêle informatie. Daarnaast relateerden de NIVRA-studenten aanzienlijk meer financiēle. gegevens aan elkaar dan de minder ervaren studenten. Deze bevindingen duiden erop dat het financièle kennisnetwerk van deze ervaren studenten aanzienlijk meer concepten en onderlinge verbindingen bevat dan het netwerk van de minder ervaren studenten. Verder probeerden de ervaren 
NIVRA-studenten meer financiēle concepten te relateren aan AO/ICconcepten dan de postdoctorale studenten. Dit geeft aan dat er bij de NIVRA-studenten verbindingen bestaan tussen het financièle netwerk en het AO/IC-netwerk. Bovendien noemden de NIVRA-studenten twee keer zoveel begrippen die specifiek betrekking hebben op bouwbedrijven dan de postdoctorale universitaire studenten. Dit wijst erop dat de kennis van de NIVRA-studenten is georganiseerd naar bedrijfstypes. Gezien het feit dat deze ervaren studenten er in alle studies relatief lang over doen om de informatie te verwerken, lijkt het erop dat de kennisnetwerken van de postdoctorale NIVRA-studenten nog niet dusdanig zijn gestructureerd dat ze relevante concepten snel kunnen activeren.

Alle drie studies suggereren dat de experts financiêle kennis, AO/ICkennis en kennis over typische bedrijfseigenschappen geïntegreerd hebben. Verder signaleerden zij de meeste aandachtspunten en relateerden zij, in de eerste twee studies, meer gegevens aan elkaar dan de andere groepen. Bovendien bleken de gelegde relaties van een andere aard te zijn dan de relaties die de minder ervaren groepen legden. De experts interpreteerden de financiële informatie voornamelijk vanuit de specifieke kenmerken die gelden voor een bepaald type bedrijf. Dat wil zeggen dat de informatie voor een groot gedeelte werd geĭnterpreteerd vanuit de specifieke kennis die ze hebben van bouw- en baggerbedrijven. Experts bleken bovendien de informatie relatief snel te kunnen verwerken, wat erop duidt dat ze in het bezit zijn van goed gestructureerde kennisnetwerken. De laatste studie gaf aan dat de antwoorden van de experts nogal kort en onvolledig waren. De vraag die daarbij open bleef staan is of experts hun beknopte antwoorden ook uitgebreider kunnen geven als ze causale vragen over financiële posten in een jaarrekening moeten beantwoorden.

Op basis van de uitgevoerde studies kan de vraag uit het eerste hoofdstuk 'of praktijkervaring van invloed is op het verwerven en gebruik van kennis' positief worden beantwoord. Er blijkt zeker een verschil te bestaan tussen NIVRA-studenten die naast de opleiding praktijkervaring hebben opgedaan en universitaire studenten die geen ervaring hebben opgedaan. Niet alleen blijken ervaren postdoctorale NIVRA-studenten beter in staat te zijn kennis toe te passen, ook geven de resultaten aan dat de postdoctorale universitair studenten minder kennis bezitten. Daarnaast ziet het ernaar uit dat de kennis van universitair opgeleiden en NIVRA-studenten anders is gestructureerd. Dit laatste komt met name naar voren uit de bevinding dat 
postdoctorale universitaire studenten aanzienlijk minder financiēle gegevens, relateren. Bovendien blijken de postdoctorale NIVRA-studenten meer verbanden te leggen tussen financiēle gegevens en gegevens over de $\mathrm{AO} / \mathrm{IC}$ dan de postdoctorale universitaire studenten. Daarnaast betrekken de NIVRA-studenten vaker het specifieke type bedrijf bij het interpreteren van de financièle informatie dan de postdoctorale universitailre studenten. De NIVRA-studenten hebben, doordat ze meer praktijkervaring hebben opgedaan, een voorsprong op de universitair opgeleide studenten. Postdoctorale NIVRA-studenten blijken zowel in kennishoeveelheid en kenniscomplexiteit als in kennisstructuur de meerdere te zijn van de postdoctorale universitaire studenten.

De resultaten uit de hier beschreven studies geven dus aan dat accountants de beschikking hebben over drie soorten kennls. De eerste soort bestaat uit kennis over de administratieve organisatie/interne controle die. voornamelijk tijdens de theoretische opleiding wordt verworven. De tweede soort kennis, financièle kennis, kan eveneens tijdens de theoretische opleiding worden verworven, mits er gelegenheid is om deze kennis toe te passen op relevante praktijksituaties. De laatste soort kennis is de bedriffstakspecifieke kennis. Dit type is alleen te verwerven door praktijkervaring. Expertise lijkt met name daarin te bestaan dat de drie genoernde soorten kennis met elkaar geỉntegreerd raken.

\section{Diecusale}

De hier gepresenteerde studies kenden een aantal tekortkomingen. Zo is de ecologische validiteit wellicht beperkt in die zin, dat accountants in de praktijk een uitgebreider takenpakket hebben dan alleen de controle van de jaarrekening. Bovendien is de taak die accountants in de hier uitgevoerde studies moesten verrichten slechts een klein onderdeel van de gehele controle van een jaarrekening. Daarnaast moet rekening worden gehouden met het feit dat de deelnemende accountants, Registeraccountant waren of daarvoor werden opgeleid. Naar bijvoorbeeld expertiseverschillen binnen een vergelijkbare beroepsgroep als de Accountants-Administratie-Consulenten kunnen dan ook slechts gissingen worden gedaan. Verder is het zo dat accountants de taken in de hier uitgevoerde studies solo uitvoerden, terwijl. ze in de dagelijkse praktijk in teams werkzaam zijn. In de toekomst zou 
empirisch onderzocht kunnen worden of het werken in teams van invloed is op hoe kennis gerepresenteerd en gebruikt wordt. De resultaten van het laatste onderzoek (Hoofdstuk 5) lleten zien dat de experts zeer beknopte antwoorden gaven. Onduidelijk blijft wat daarvan de oorzaak is. Tenslotte zou het van belang, kunnen zijn ook het lange-termijn effect na te gaan van de vaardigheidstraining Financiële Analyse en Cijferbeoordeling.

\section{Implicaties}

Niet alleen uit wetenschappelijk onderzoek komt naar voren dat praktijkervaring van groot belang is voor het kunnen oplossen van complexe praktijkproblemen. Ook in de accountancypraktijk bestaat al sinds de komst van de universitaire accountancy-opleiding de indruk, dat als universitair opgeleide accountants naast een theorie-oplelding een uitgebreidere praktijkopleiding zouden volgen, dit mogelijk een verbetering zou zijn voor de professie. In 1993 is dan ook als gevolg van de $8 \mathrm{e}$ Europese Richtlijn wettelijk vastgelegd dat accountancystudenten vanaf 1999 een met goed gevolg afgeronde stage moeten hebben doorlopen. Aangezlen de duur van de stage ten minste drie jaar is (in full-time dienstverband), betekent dit dat studenten vanaf september 1996, om Reglsteraccountant te kunnen worden, de stage-opleiding moeten gaan volgen. De stage-opleiding houdt in dat studenten in die drie jaar, 3.840 uur stage lopen op bij een erkend stagemeester (NIVRA, 1996). Voordat studenten echter aan die praktijkopleiding mogen beginnen dienen ze de volgende inleidende vakken te hebben. gehaald: Algemene Economie, Bedriffseconomie, Recht, Wiskunde, Statistiek, Boekhouden (FIS), Algemene Organisatie, Belastingrecht (Fiscaal Recht), Externe Berichtgeving. Administratieve Organisatie en Leer van de Accountantscontrole (Auditing). Dit betekent dat universitaire studenten het doctoraal programma zullen moeten hebben afgerond en dat NIVRAstudenten de tweede fase moeten hebben afgesloten. Pas als stagiaires alle hoofdvakken goed hebben afgerond mogen ze het derde stagejaar ingaan. Dit betekent dat universitair opgeleide stagialres in feite het postdoctorale programma van de universiteit en NIVRA stagiaires de derde fase van de NIVRA-Nijenrode opleiding moeten hebben voltooid (De Accountant, 1995; NIVRA, 1996). 
Vergeleken met de huidige situatie wordt in dit nieuwe onderwijsprogramma het verschil in praktijkervaring tussen NIVRA-studenten en universitaire studenten dus iets verkleind. De NIVRA-studenten zullen bij afronding van de opleiding niet meer zeven jaar, maar slechts vierenhalf jaar meer praktijkervaring hebben dan de universitaire studenten.

Tijdens de praktijkopleiding zal worden getoetst op welke wijze stagiaires de opgedane kennis in de praktijk toepassen. Daarnaast zal worden gekeken of stagiaires in staat zijn controle-relevante werkzaamheden uit te voeren. De werkzaamheden bestaan onder andere uit: controleplanning, vastlegging en beoordeling van administratieve organisatie en interne controlesystemen, risico-analyse en materialiteitsbepaling, beoordeling van jaarrekeningen, onderkennen en oplossen van problemen ten aanzien van waarderingsgrondslagen en jaarrekeningpresentaties (NIVRA, 1996).

Volgens Schōn (1987) is een curriculum, zoals het nieuwe accountancycurriculum, waarin eerst de basiswetenschappen, daarna de toegepaste wetenschappen en als laatste het toepassen. van kennis op 'real-world' problemen aan de orde komen, onvoldoende geschikt om studenten voor te bereiden op ingewikkelde praktijksituaties. Schōn adviseert om direct met de kennis de praktijk in te gaan, dus 'learning by doing'. Volgens hem is dat een voorwaarde om studenten te leren omgaan met onvoorspelbare situaties, complexiteit, uniekheid en conflicterende situaties. Glaser (1991) stelt het iets minder extreem. Hij is van mening, dat het in ieder geval zeer belangrijk is om simulatieomgevingen te scheppen waarin studenten worden gestimuleerd de opgedane theoretische kennis toe te passen. Volgens hem is het wel een vereiste om studenten te laten begeleiden door competente personen op dat specifieke gebied. Het gaat er volgens Glaser met name om, dat studenten leren wanneer ze kennis kunnen toepassen en hoe ze kennis moeten toepassen. Bransford, Franks, Vye en Sherwood (1989) stellen dat de beste manter om studenten voor te bereiden op het gebrulk van relevante kennis is, studenten ervaring te laten opdoen met problemen die overeenkomen met praktijksituaties waarin ze later terecht komen. Volgens Bransford et al. (1989) zal de ontwikkeling van expertise op deze wijze in een veel kortere tijd bewerkstelligd worden dan nu het geval is.

Resultaten uit het derde onderzoek bevestigen het vermoeden dat het van belang is vaardigheidstrainingen in te voeren waarin praktijksituaties gesimuleerd worden. De verschillen tussen onervaren vierdejaars studenten 
en de wat meer ervaren postdoctorale universitair studenten ten aanzien van het kunnen toepassen van financiêle kennis worden aanzienlijk kleiner als vierdejaars studenten een vaardigheidstraining hebben gevolgd in het analyseren van financiēle informatie. Zo'n specifieke training in financiēle analyse en cijferbeoordeling van een realistische casus werpt haar vruchten beslist af.

Samenvattend kan gesteld worden dat het belangrijk is de studenten de mogelijkheid te geven om datgene wat ze aan theoretische kennis hebben opgedaan toe te laten passen in de praktijk. Gezien het feit dat in het accountancy domein de beslissing reeds is genomen om een stageperiode in te lassen na het doctoraal programma is het aan te raden om tijdens het doctoraal zoveel mogelijk cursussen en vaardigheidstrainingen aan te bleden waarin studenten niet alleen theoretische kennis krijgen aangereikt, maar waarin ze eveneens leren de kennis toe te passen op praktijksituaties of simulaties daarvan.

Een opvallend verschil tussen ervaren postdoctorale NIVRA-studienten enerzijds en onervaren vierdejaars studenten en minder ervaren postdoctorale universitaire studenten anderzijds, betrof de mate waarin zij financiële informatie en informatie over de administratieve organisatie en interne controle (AO/IC) integreerden. Dit verschil zou eveneens van betekenis kunnen zijn voor de invulling van het onderwijsprogramma van de accountantsopleiding. De groepsverschillen die in de drie uitgevoerde studies gevonden zijn tonen aan dat minder ervaren en onervaren studenten nauwelijks in staat zjjn om $\mathrm{AO} / \mathrm{IC}$ informatie en financiële informatie aan elkaar te relateren. Frederick en Libby (1986) hadden ook al geconstateerd dat in tegenstelling tot de onervaren studenten, ervaren accountants wel het verband tussen zwakheden in de interne controle en onregelmatigheden in de jaarrekening zagen. Vermoedelijk hebben onervaren en minder ervaren accountancystudenten nogal wat moeite om kennis over de $\mathrm{AO} / \mathrm{IC}$ en financiēle kennis opgedaan tijdens vakken als Financiële Informatie Systemen en Externe Berichtgeving te integreren.

Cavanaugh (1993) heeft data gepresenteerd waaruit blijkt dat vele professionele curricula georganiseerd zijn per discipline. In zo'n professioneel curriculum worden studenten per vak voorbereid om als specialisten op dat ene gebied te kunnen functioneren. Volgens haar zou het. een aanzienlijke verbetering zijn als in een opleiding de verschillende disciplines geintegreerd 
aan de studenten zouden worden aangeboden. Cavanaugh is van mening dat de aansluiting tussen opleiding en praktijk groter wordt als er sprake is van een integratie tussen verschillende disciplines. In de praktijk zullen de meeste problemen immers zo complex zijn dat ze alleen opgelost kunnen worden als de kennis die is opgedaan bij de verschillende disciplines geintegreerd wordt toegepast. Een belangrijke bijdrage die het onderwijs kan leveren aan de integratie van de verschillende disciplines is de studenten te stimuleren om dat wat ze bij het ene vak leren bij het volgende vak toe te passen. Volgens Boshuizen (1995) zal de extra tijd die in het doctorale programma wordt besteed aan het integreren van verschillende vakken als resultaat hebben dat het leren in de praktijk sneller zal gaan.

Als er gekeken wordt naar het programma van de doctorale accountancy-opleiding bij de Rijksuniversiteit Limburg, dan is er één cursus waarin sprake is van integratie tussen verschillende vakken. Dit is de vierdejaars cursus Auditing (voor een beknopte inhoud van deze cursus zie Hoofdstuk 1). In de cursus Auditing wordt onder andere een overzicht gegeven van alle taken en functies die een accountant kan vervullen. Nadere beschouwing van de beschrijving van de cursus maakt duidelijk dat gestreefd wordt naar integratie in de cursus:

Voorts wordt er aandacht besteed aan een integratie tussen de vakken 'AO' en 'Leer van de accountantscontrole' middels behandeling van de typologie der toepassingen toegespitst op de accountantscontrole (Blokbeschrijvingen Doctoraalonderwijs 1993/1994)

De verkregen resultaten in de hoofdstukken 3,4 en 5 laten zien dat de geplande integratie tussen kennis van $\mathrm{AO}$ en de accountantscontrole goed is gelukt. De aan de uitgevoerde studies deelnemende accountancy groepen blijken allen goed in staat te zijn om kennis van de AO/IC toe te passen op een taak waarin aandachtspunten voor de accountantscontrole geselecteerd moeten worden. Helaas geven de resultaten ook aan dat de integratie van financièle kennis, kennis van AO en kennis van de accountantscontrole minder goed is verlopen. Juist ten aanzien van de integratie van kennis over $\mathrm{AO}$, kennis van de accountantscontrole en van financiêle kennis verschilden de ervaren NIVRA-studenten en de experts sterk van de minder ervaren studenten. Met name de vierdejaars studenten gaven aan dat zij veel moeite hebben om financièle kennis toe te passen op casus waarin de nadruk ligt op aandachtspunten voor een eventueel uit te voeren controle. Zij hebben 
financiēle kennis (wat zij 'bedrijfseconomische kennis' noemen) gewoonweg niet geïntegreerd met kennis over de accountantscontrole. Uit de evaluatie in het derde onderzoek beschreven in Hoofdstuk 5 blijkt dat de vierdejaars studenten wel op de hoogte zijn van het feit dat financiêle kennis belangrijk is voor de accountantscontrole. Deze studenten weten dus wel dat het relateren van financiêle kennis aan de accountantscontrole belangrijk is, maar ze weten niet hoe ze die relatie tot stand moeten brengen. Een mogelijke verbetering voor het doctorale accountancyprogramma kan zijn dat in het vak Auditing zowel kennis van $A O$ en Leer van de Accountantscontrole als financiële kennis van FIS, Externe Berichtgeving en Financièle analyse en cijferbeoordeling aan de orde komen. Wanneer financiêle kennis, kennis van $\mathrm{AO}$ en kennis over controleleer geîntegreerd worden aangeboden, zullen studenten leren dat de typologieèn van Starreveld (1991) ook op financiêle kennis toegepast kunnen worden. Aangezien de resultaten uit de studies in dit proefschrift suggereren dat bij experts de typologie van het bedrijf een grote rol speelt bij het interpreteren van financiële informatie kan zo'n nieuwe cursus Auditing voor studenten een steun zijn bij de interpretatie van financiële informatie.

Ook de postdoctorale studenten die aan de uitgevoerde onderzoeken hebben deelgenomen relateerden minder financiële kennis aan AO/IC-kennis en kennis over de controleleer dan de meer ervaren NIVRA-studenten en de experts. Alle postdoctorale studenten die hebben deelgenomen aan de hier uitgevoerde studies zaten in de eindfase van de postdoctorale cursus Leer van de Accountantscontrole. Men zou dạn mogen verwachten dat studenten aan het eind van het postdoctorale programma alle kennis hebben opgedaan die belangrijk is om in de praktijk goed te kunnen functioneren. Zoals de resultaten lieten zien blijkt dit niet voor alle groepen te gelden. Dit is enigszins begrijpelijk, omdat de resultaten aangeven dat het integreren van kennis nauw samenhangt met praktijkervaring. Aangezien de universitair opgeleide studenten gemiddeld zo'n acht maanden praktijkervaring en de NIVRA-studenten gemiddeld zo'n zeven jaar praktijkervaring hadden ten tijde van de onderzoeken, hebben de postdoctorale universitaire studenten duidelijk een achterstand. Deze achterstand wordt versterkt, doordat in de postdoctorale cursus Leer van de Accountantscontrole (LAC) slechts twee à drie casus behandeld worden waarin cijferbeoordeling, financiēle analyse en de accountantscontrole geïntegreerd worden aangeboden. Voor de postdoctorale universitaire studenten lijkt de combinatie van acht maanden 
praktijkervaring die ze tijdens de postdoctorale opleiding hebben opgedaan en de behandeling van drie casus over de toepassing, van financiēle kennis op een controletaak te weinig om financiêle kennis en kennis van AO en controleleer goed te kunnen integreren. Pas wanneer ze meer praktijkervaring opdoen komen ze in de gelegenheid deze lacune weg te werken.

Zoals echter eerder is beschreven zal met de komst van de nieuwe praktijkopleiding het verschil in het aantal jaren praktijkervaring tussen NIVRA-Nijenrode 29 -studenten en universitair opgeleide studenten verminderen. In de toekomst betekent dat, dat de verschillen in toepassing van verschillende types kennis tussen NIVRA-Nijenrode opgeleide en andere universitair opgeleide studenten mogelijk verminderen. Daarnaast zullen de postdoctorale universitaire studenten waarschijnlijk beter worden in het integreren van verschillende disciplines als ze in het doctorale programma een cursus Auditing hebben gevolgdl waarin financiēle kennis, kennis van AO en kennis van de controleleer geïntegreerd wordt aangeboden. Het ziet er dus naar uit dat een doctorale cursus Auditing waarin meer aandacht wordt geschonken aan financiële kennis, accountancystudenten op de lange duur beter voorbereidt op de complexe problemen die ze tijdens de nieuwe praktujkopleiding zullen tegenkomen.

Het advies om de integratie tussen financièle kennis, kennis van $\mathrm{AO}$ en Leer van de Accountantscontrole al in het doctoraal programma al te laten plaatsvinden heeft meerdere redenen. Een van de belangrijkste redenen is dat als studenten in het doctorale programma al leren dat kennis van $\mathrm{AO}$, Controleleer en financièle kennis aan elkaar gerelateerde vakken zijn, zij in het postdoctorale programma en dus in de praktijkopleiding, veel sneller nieuwe aansluitende kennis kunnen verwerven (Boshuizen, 1995). Glaser (1995) geeft eveneens het advies om kennis niet als losse afzonderlijke ellandjes aan te dragen maar om kennis, zodra het mogelijk is, geïntegreerd te presenteren zodat studenten meteen geconfronteerd worden met de complexiteit van de problemen. Het advies luidt dan ook dat er in het doctorale programma al een integratie tussen vakken als $\mathrm{AO}$, Externe Berichtgeving. Financiēle Informatie Systemen en Financiële Analyse en Cijferbeoordeling plaats moet vinden. Het advies dat aan docenten van het postdoctorale programma en de praktijkopleiding gegeven kan worden is dat

29 De proefpersonen die aan de hier uitgevoerde studies hebben deelgenomen waren nog van voor het samengaan van het NIVRA met Nijenrode. Vanaf 1994 is dat veranderd en worden NIVRAstudenten NIVRA-Nijenrode-studenten genoemd. 
de behandelde theorieẽn nauw aan moeten sluiten bij de situaties die studenten op dat moment in de praktijk tegen komen. Schön (1987) en Harris (1993) concludeerden dat studenten die theoretische kennis direct in praktijk kunnen brengen beter in staat zijn de complexe problemen uit de praktijk op te helderen dan studenten die de theorie niet direct in praktijk kunnen brengen. De voorwaarde is wel dat de opgedane theoretische kennis aansluit bij de problemen die de studenten tegen komen in de praktijk.

In het kort komen de belangrijkste aanbevelingen voor de accountancy opleiding op het volgende neer: in het doctoraalprogramma moeten studenten theoretische kennis toe kunnen passen op realistische casus uit de praktijk en moet er meer aandacht komen voor de toepassing van financiële kennis bij het oplossen van accountancy problemen. Dit laatste kan verwezenlijkt worden door in de vakken Auditing en Leer van de Accountantscontrole meer nadruk te leggen op de integratie van de vakken Administratieve Organisatie, Leer van de Accountantscontrole, Externe Berichtgeving. Financiële Informatie Systemen en Financiële Analyse en Cijferbeoordeling. Voor het postdoctorale onderwijsprogramma luidt het advies: zorg ervoor dat behandelde theorieẽn nauw aansluiten blj de situaties die studenten op dat moment in de prakt1jk tegenkomen. 
- 144 - 
The first part of Chapter 1 describes the development of the auditing profession. At the beginning of the $20^{\text {th }}$ century, an auditors main duties besides bookkeeping, were improving the updating of balance sheets and profit-and-loss accounts. Nowadays, one of the main duties of an auditor is to audit financial statements. He/she must determine whether the financial statements are stated in accordance with specified accounting principles (Arens \& Loebbecke, 1994). In addition, auditors carry out audits regarding mergers and takeovers as well as giving advice on such matters as organisational structure, information supply, etc.

In this thesis, it is the main duty of auditors 1.e. the audit of financial statements which is the object of study. It must, however, be noted that especially the first phase of the auditing process which forms the context upon which and in which the subjects in the current empirical studies acted.

The second part of Chapter 1 lists the varlous courses or curricula which can be followed in order to become a certifled auditor (Registeraccountant). The HEAO (School of Higher Economic Administrative Education) course comprises, in fact, only a part of the necessary training or education. To become a certifled auditor, these students must continue their training for further six years at the NIVRANijenrode university or for at least a further three years at a 'regular' university. The NIVRA-Nijenrode university auditing course is a part-time course open to students already working in this field. These students attend the course one day a week for an average of eight years. Students attending the full-time auditing course at a 'regular' university need approximately six years to become a certified auditor. Only in the last two years of their course, will they gain practical experience.

In 1962 a Law of Auditors (Wet op de Registeraccountants) prescribed that the students attending the NIVRA-Nijenrode University (then NIVRA students) and those attending a 'regular' university sit the same national examination. The overview in Chapter 1 of the auditing courses f.e. curricula shows that the curricula of the NIVRA-Nijenrode University and the 'regular' universities are almost identical. One essential difference between the two types of universities is, however, the amount of practical experience gained. Students of the NIVRA-Nijenrode University have, on 
average, seven to nine years of practical experience before receiving the title 'Registeraccountant', whereas students attending a 'regular' university have, on average, one to two years of experience before receiving this title. As both groups use the same title, they must be regarded as equal. However, the question arises as to whether auditing students who acquire both theoretical knowledge and practical experience from the outset and students who gain practical experience only after four years of theoretical training really can be considered equal.

On the basis of literature and empirical studies, this thesis examines the role of practical experience i.e. expertise in the auditing field.

Chapter 2 looks at what is known in literature about the influence of expertise in the auditing field. Several mainstreams are presented: studies based on Brunswik's Lens model, heuristic studies, cognitive reasoning studies and studies which examines the relationship between the level of expertise and knowledge and the structure of knowledge.

Researchers who examined auditing expertise from the perspective of the Brunswik Lens model tried to discover if there was a positive relationship between the level of expertise and a certain number of aspects they believed to be Important to an auditor's judgment, these being: consensus, stabllity, accuracy en self-insight. The findings of most studies based on the Lens model could, however, barely confirm the expected relationship between the level of expertise and consensus, stabllity and self-insight. A positlve exception was the accuracy of the final judgment. This variable was found to be positively related to the level of expertise. However, how the final judgment was come to was difficult to establish on the basis of the Lens studies.

In the eighties the relationship between the level of expertise and the use of heuristics was examined. Frederick and Libby (1986) carried out a number of experiments which examined the relationship between the level of expertise and the use of heuristic 'representativeness'. This heuristic means that a judgment is formed based upon the correspondence of something or someone with a prototypical case. Results of these experiments confirmed Frederick's and Libby's expectations. Experts based their judgements about new information on similarities with prototypical cases, whereas inexperienced auditors did not.

In the eighties, auditing researchers also became interested in the reasoning process. The founders of this research paradigm were Newell and Simon (1972). Einhorn and Hogarth (1981) developed a. model, based 
upon the problem solving model of Newell and Simon, wherein the reasoning process was subdivided in four phases: information acquisition, evaluation, action and feedback. Several studies have been carried out examining the relationship between the level of auditing expertise and the reasoning process. Bouwman (1978, 1984), for instance, examined the differences in reasoning between experienced and inexperienced auditors when making financial analyses. Biggs, Mock and Watkins (1988) researched if there were differences in the reasoning process during the pre-planning phase of the audit. Also, Libby and Frederick (1990) and Bedard and Biggs (1991) carried out studies examining the relationship between the level of expertise and the reasoning process. The results indicated that experienced and inexperienced auditors differed in the way they reason. However, the results obtained were not unequivocal. Bouwman's results indicated that the groups differed qualitatively in the reasoning, phase whereas Biggs et al. (1988) found qualitative differences in the information acquisition phase but not in the reasoning phase.

Since the beginning of the eightles, studies have also been carried out in several domains examining the relationship between the level of expertise and knowledge and knowledge structures. These studies provided some consistent results. Findings indicated that experts had more domain knowledge than non-experts. Moreover, an expert's domain knowledge appeared to be structured differently than that of novices. Furthermore, the processing time was found to be related to the level of expertise. A model which might explain the results obtained is the model wherein knowledge is represented as a conceptual knowledge network. In the former, concepts represent the features of an idea or a fact. The links between the concepts represent the relationship between ideas or facts. In addition, it is assumed that there is not just one conceptual network but many. It is claimed that each (sub)domain of knowledge has its own conceptual knowledge network (Boshuizen, 1995; Feltovich \& Barrows, 1984). Just as there are links between concepts, there are links between the different knowledge networks. The assumption is, now, that the more experience someone has, the more concepts a person will have and the larger the number of links there will be within a conceptual network and between the different conceptual networks.

The relationship between the level of expertise and differences in knowledge and knowledge structures has been researched in the auditing field since the middle of the eighties. The amount of knowledge and structure of knowledge has been researched by Choo and Trotman (1991), 
Christ (1993), Frederick (1991), Frederick, Heiman-Hoffman and Libby (1994), Moeckel (1990), Rennie (1991, Tubbs (1992), amongst others. The amount of knowledge and structure of knowledge has mostly been examined by means of the 'recall method'. This method assumes that subjects with an extensive knowledge network have more possibilities to relate new information to existing concepts in the network and are, therefore, better able to recall new relevant information than subjects who have a less extensive knowledge network. Experts of whom it is expected that they have more domain knowledge should, therefore, be able to recall more new relevant information than novices. Results Indicated that expert auditors indeed had a more extensive recall than novice auditors. In addition, expert auditors also produced more meaningful clusters in their recall than novice auditors. A study by Christ (1993) showed that expert auditors did not only recall more information. but they also recalled different types of information. Experts recalled, for Instance, significantly more financial information than novices whereas with regard to the information concerning the internal control procedures there was no difference in recall.

The expertise studies in the auditing domain thus far presented have produced some quite interesting results. The relationship between auditing expertise and the amount and organization of recall have, for instance, been consistently positive. Another interesting finding was the relationship between auditing expertise and the type of knowledge. However, there has been only one study which has examined this thus far. Furthermore, there has been little or no research as to the way this knowledge develops between the stages inexperienced students to experienced students. Also, the registration of processing time has been neglected in the auditing field. In addition, there have only been two studies which have examined the relationship between auditing expertise and the application of knowledge. A final criticism concerns the reticence in makıng practical suggestions to auditing education and auditing practice.

In response to these shortcomings, three studies were carried out in this thesis using diverse research methods as recall, thinking aloud and knowledge assessment. These empirical studies were carried out so as to find answers to the following research questions. first, what is the influence of practical experience on the development of a conceptual knowledge network? Second, do expert auditors have more domain 
knowledge than less experienced auditors? Third, are expert auditors better able to apply their domain knowledge than less experienced auditors? Is there a relationship between auditing expertise and type of knowledge? Finally, does expertise affect the speed of information processing?

In the first study (Chapter 3), the relationship between the level of expertise and the application of knowledge was examined. In other words, it was expected that expert auditors were better at indicating initial audit issues i.e. certain points of particular interest for a company in light of a possible audit than less experienced auditors. In addition, the relationship between the level of expertise and size and content of the knowledge representation was examined using the 'recall method'. It was expected that experts and non-experts would differ in the type of knowledge they use. The final research question in this particular study was about the relationship between the level of expertise and processing time. Fourty subjects of five levels of expertise participated: first year economy students; fourth year auditing students; postgraduate students who had followed the auditing curriculum at a 'regular' university with 2,5 years of experience (postgraduate university students); postgraduate NIVRA ${ }^{30}$ students who had followed the part-tlme NIVRA program with seven years experience. The fourth group consisted of expert auditors with twelve years of experience. The subjects were presented three auditing case studies in which two types of information were given i.e. Information about the internal control procedures and a summary of a financial statement. After having studied a case, they first had to indicate initial audit issues 1.e. which points could be of particular interest in light of a possible audit. A second task was to write down everything they could recall of the case. Results showed that the four groups did not differ in their application of knowledge about the internal control procedures. On the other hand, groups differed considerably in their application of financial knowledge. Fourth-year students with no experience and postgraduate students with two and a half years' experience only applied knowledge about the internal control procedures. The intermediate NIVRA students with seven years' experience and the expert auditors, on the other hand, applied not only knowledge about the internal control

30 NIVRA stands for the Netherlands Institute of Registeraccountants (Certified Public Accountants). Students who follow this educational program work four days a week and spend one day a week at school for five to ten years. 
procedures but also financial knowledge. The NIVRA students tried to integrate knowledge about internal control procedures with financial knowledge. The experts integrated knowledge about internal control procedures with financial knowledge and typical business knowledge. However, these differences in application of knowledge did not lead to differences in literal recall of the information presented. Nonetheless, the groups differed significantly in the amount of inferred recall. The NIVRA students and the experts, in particular, made significantly more inferences ${ }^{31}$ in their recall than the less experienced groups. The time subjects took to process the case information was inversely U-related with the level of expertise. That is to say, fourth year students and experts were faster in reading the case information than the two intermediate groups.

A subsequent study (Chapter 4) was conducted to find out whether the relationship observed between the level of expertise and the use of financial knowledge could be confirmed with another method: the thinking aloud method. We, also, expected to find the level of expertise and the size of the knowledge representation to be positively related. A further expectation concerned the relationship between the level of expertise and the complexity of the representation. In this second study, 16 subjects participated: fourth year auditing students with no experience; postgraduate university students with an average of eight months' experience; postgraduate NIVRA students with five years' experience and expert auditors who had twelve years' experience. Subjects had to think aloud whilst going through a financial statement of a contracting firm. All subjects received two different cases. Afterwards, they had to indicate the initial audit issues i.e. which points could be of particular interest in light of a possible audit. Results indicated that with regard to the audit Issues, there were large differences between the two rather inexperienced groups and the more experlenced NIVRA students and the experts. For example, the fourth year students with no experience indicated two issues, on average, whereas experts indicated five. Also, the size and complexity of the representation seemed to be positively related to the level of expertise. The fourth-year students and the postgraduate university students hardly tried to link financial figures to each other whereas experts linked at least six. Furthermore, results indicated that

${ }^{31}$ Inferences stand for correct conclusions and interpretations 
the inexperienced students linked only financial figures together if listed closely together, while the more experienced groups also linked financial figures listed further apart. Moreover, the experts linked not only financial figures to each other but also to the characteristics of the specific type of company. The relationship between the level of expertise and time to process the case information was found to be inversely Ushaped, as in the first study .

Thus, despite fourth year and postgraduate students completing all the relevant financial courses such as Bookkeeping, Financial Accounting and Financial Information Systems, they do not use this prior knowledge in an auditing task. The question that then arises is, have these students lost their financial knowledge or is it a matter of 'inert' knowledge 1.e. knowledge that is applied only to situations similar to those used in the curricula. In the first and second empirical study described in this thesis, 'inert' knowledge could have been caused by a difference in context of the audit task given to students with that of the courses in the auditing curricula. The failure of students attending the auditing curricula at a 'regular' university to apply financial knowledge to an auditing task could lie in the fact that they are especially trained to apply knowledge about internal control procedures to an auditing task and there is no specific course which integrates financial knowledge with auditing tasks.

The third and final study (Chapter 5) examines if the results obtained in the previous two studies is caused by a lack of financial knowledge or by a difficulty in using financial knowledge in a specific context. In addition, this study examines if the level of expertise and the number of references to characteristics of the type of business is positively related. Finally, the relationship between the level of expertise and the processing time is examined. Again, subjects of four levels of expertise participated in this study: fourth year auditing students postgraduate university students, postgraduate NIVRA students and expert auditors. In total, 106 subjects participated. Subjects received a financial statement and had to answer ten questions about specific relationships between the financial figures in this statement. Results indicated that, in correspondence with the previous studies. inexperienced fourth year students have difficulties in applying financial knowledge. Yet, when these fourth year students followed a course in which they learned how to apply their financial knowledge in an auditing context, they performed much better on the assessment than when they 
had not attended such a course. The postgraduate university students performed better on the assessment than both the fourth year groups. However, the performance was only slightly better than the fourth year group which had followed the specific financial auditing course. The NIVRA students had the highest score on the assessment. The expert auditors answered less extensive than expected. They gave terse answers and often referred to answers on corresponding questions. Taking into account the processing time, it seemed that a number of experts completed the test in a very short period of time which could explain the rather low score on the assessment. A final result indicated that expert auditors mentioned much more specific business facts in their answers than the less experienced groups.

In the last chapter (Chapter 6) the previous chapters are summarised. After this summary, several conclusions are drawn. The first conclusion concerns the research question of the influence of practical experience on the development of a conceptual knowledge network. Results suggested that fourth year students without specific training in the application of financial knowledge do have a rather extensive and complex knowledge network of internal control procedures, but that their financial knowledge network is much less extensive and complex. However, when these fourth year students attend specific training in financlal skills, it appears that their financial network becomes larger with more links between the concepts than the students who did not follow training in financial skills. The knowledge networks of the postgraduate university students seem to be more extensive and more complex than the networks of the fourth year students. These intermediate students seem to have only some links between the financial network and the internal control network. Results indicate furthermore that the postgraduate NIVRA students not only have a more extensive and complex internal control network than the less experienced groups but also their financial network is more extensive and complex than the networks of the less experienced groups. Moreover, these NIVRA students seem to have many more links between the networks than the less experienced students. The expert auditors appear to have the largest number of links between the knowledge networks. It seems that experts not only have a large number of links between. the financial network and the internal control network, but that they also have links to a knowledge 
network in which characteristics of different types of businesses are represented.

Thus, the results from the current studies indicated that level of expertise is positively related to the size of the knowledge networks. Secondly, expertise was positively related to the complexity of the networks. That is " the level of expertise was positively related to the number of links within and especially between the different networks. A third finding was that the expert auditors indicated more and better audit issues, than the less experienced auditors. Yet, in the assessment study. expert auditors did not perform better than the less experienced groups, although their answers were nnore specific than the answers of the less experienced groups. Another finding was that level of expertise was significantly related to knowledge of types of businesses. A flnal result showed that expert auditors and fourth year students were faster in information processing than the two intermediate groups.

Also, for the studies in this thesis some shartcomings can be pointed out. For example, the ecological validity is somewhat limited: in real life an auditor's job is more than just preplanning an audit. Furthermore, subjects in the current studies were acting alone, while in practice they work in teams.

The last chapter ends with a paragraph about implications for practice and education. Although the auditing curricula are being innovated considerably at the moment, some recommendations might stlll be appropriate. The first recommendation is, give graduate students the opportunity to apply theoretical knowledge to realistic cases from the beginning of the course. A second recommendation concerns the application of financial knowledge. The advice is to integrate financial knowledge with auditing problems. For instance, teachers can integrate courses like Financial Bookkeeping or Financial Management with a course like Theory of Auditing. The recommendation for teachers in the postgraduate course is: try to match auditing theories with practical situations students are confronted with at that moment. 
-154 - 
Abdolmohammadi, M. \& Wright, A. (1987). An examination of the effects of experience and task complexity on audit judgments. The Accounting Review, 62, 1-13.

Accountant, de (1995). Kalkman, S. (Red.), Is het ei gelegd? 3, 199 - 203.

Adelson, B. (1981). Problem solving and the development of abstract categories in programming languages. Memory \& Cognition, 9, 422-433.

Anderson, J. R. (1995). Cognitive Psychology and its Implications. New York: Freeman.

Arens, A. A. \& Loebbecke. J. K. (1994). Auditing. an integrated approach. New Jersey: Prentice-Hall.

Ashton, A. H. (1991). Experience and error frequency knowledge as potential determinants of audit expertise. The Accounting Review。 66, 218-239.

Ashton, R. H. (1974). An experimental study of internal control judgments. Joumal of Accounting Research, 143-157.

Ashton. R. H. (1982). Human Information Processing in Accounting: Studies in Accounting Research \# 17. Sarasota, FL: American Accounting Association.

Ashton, R. H. \& Kramer, S. S. (1980). Students as surrogates in behavioral accounting research: some evdence. Joumal of Accounting Research, 115.

Ashton, R. H., Kleinmuntz, D. N., Sullivan, J. B. \& Tomassini, L. A. (1988). Audit Decision Making. In: Abdel-Khalik A. R. \& Solomon I. (Eds.). Research Opportunities in Auditing: the second decade. Sarasota, FL: American Accounting Association.

Bédard, J. (1989). Expertise in auditing: myth or reallty? Accounting. Organizations and Soclety, 14, 113-131.

Bedard, J. C. \&i Biggs, S. F. (1991a). The effect of domain-specific experience on evaluation of managernent representations in analytical procedures. Auditing: A Journal of Practice and Theory, 10, 77-90.

Bedard, J. C. \& Biggs, S. F. (1991b). Pattern recognition, hypotheses generation, and auditor performance in an analytical task. The Accounting Review, 66, 622-642. 
Biggs, S. F., Mock, Th. J. \& Watkins, P. R. (1988). Auditors' use of analytical review in audit program design. The Accounting Review, 63, 148-161.

Bonner, S. E. (1990). Experience effects in auditing: the role of task-specific knowledge. The Accounting Review, 65, 72-92.

Bonner, S. E. (1994). A model of the effects of audit task complexity. Accounting, Organizations and Society, 19, 213-234.

Bonner, S. E. \& Lewis, B. L. (1990). Determinants of auditor expertise. Journal of Accounting Research, 28, 1-20.

Boritz, J. E., Gaber, B. G. \& Lemon, W. M. (1987). An Experimental Study of Review of Preliminary Audit Strategy by External Accountants. Toronto: Canadian Academic Accounting Association.

Boshuizen, H. P. A.. (1989). De Ontwikkeling van Medische Expertise; een cognitief psychologische benadering. [On the development of medical expertise; a cognitive psychological approach]. Doctoral dissertation. Haarlem, The Netherlands: Thesis publishers.

Boshuizen, H. P. A. (1995). Teaching for expertise. In: Gijselaers, W. H., Tempelaar, D. T., Keizer, P. K., Blommaert, J. M., Bernard, E. M. \& Kasper, H. (Eds.) Educational Innovation in Economics and Business Administration. Dordrecht: Kluwer.

Boshuizen, H. P. A. \& Claessen, H. F. A. (1981). De Cognitieve Verwerking van Medische Gegevens door Artsen en Studenten. (Onderzoek van onderwijs RL 10). Maastricht: O\&O, Rijksuniversiteit Limburg.

Boshuizen. H. P. A. \& Schmidt, H. G (1992). On the role of biomedical knowledge in clinical reasoning by experts, intermediates and novices. Cognitive Science, 16, 153-184.

Bouwman, M. J. (1978). Financial diagnosis: A Cognitive Model of the processes involved. Unpublished dissertation: Carnegie-Mellon University.

Bouwman, M. J. (1984). Expert versus novice decision making in accounting: a summary. Accounting. Organizations and Society, 9, 3.25327.

Bransford, J. D., Franks, J. J. Vye, N. J. en Sherwood, R. D. (1989). New approaches to instruction: because wisdom can't be told. In: Vosniadou, S. en Ortony. A. (Eds.). Similarity and Analogical Reasoning. Cambridge: Cambridge University Press. 
Bransford, J. D., Sherwood, R. D., Kinzer, C. K., en Hasselbring, T. S. (1987). Macro-contexts for learning: initial findings and issues. Applied Cognitive Psychology, 1, 93-108.

Breuker, J. A., Elshout, J. J., van Someren, M. W. en Wielinga, B. J. (1986), Hardopdenken en protokolanalyse. Tyjdschrift voor Onderwijsresearch, $11,241-54$.

Bruyne, A. L. de (1980). De geschiedenis van de beroepsorganisatie der accountants in Nederland, 1895-1975. Hoofdzaken uit de voorgeschiedenis en de beginjaren van het Nederlands Instituut van Registeraccountants. Alphen aan de Rijn: Samsom B. V.

Camerer, C. F. en Johnson, E. J. (1991). The process-performance paradox in expert judgment; How can experts know so much and predict so badly? In: Ericsson, K. A. \& Smith, J. (Eds.) Toward a General Theory of Expertise: Prospects and Limits. Cambridge, MA: Cambridge University Press.

Cavanaugh, S. Hixon (1993). Connecting education and practice. In: Curry L., Wergin, J. F., \& Associates. (Eds.) Educating Professionals. Responding to new Expectations for Competence and Accountability. San Francisco: Jossey-Bass.

Ch1, M. T. H., Feltowich, P. J. \& Glaser, R. (1981). Categorization and representation of physics problems by experts and novices. Cognitive Science, 5, 121-152.

Chi, M. T. H., \& Glaser, R. (1988). Overview. In: Chi, M. T. H., Glaser, R. \& Farr, M. J. (Eds.) The Nature of Expertise. Hillsdale, NJ: Erlbaum.

Chiesi, H. L., Spilich, G. J. \& Voss, J. F. (1979). Acquisition of domain related information in relation to high and low dornain knowledge. Journal of Verbal Leaming and Verbal Behavior, 18, 257-273.

Choo, F. \& Trotman, K. T. (1991). The relationship between knowledge structures and judgments for experlenced and inexperienced auditors. The Accounting Review, 66, 464-485.

Christ, M. York (1993). Evidence on the nature of audit planning problem representations: an examination of auditor free recalls. The Accounting Review, 68, 304-322.

Collins, A. M. \& Loftus, E, F. (1975) A spreading-activation theory of semantic processing. Psychological Review, 82, 407-428.

Collins, A. M. \& Quillian, M. R. (1969). Retrieval time from semantic memory. Joumal of Verbal Learning and Verbal Behavior, 8, 240-247. 
Coughlin, L. D. \& Patel, V. L. (1987). The Use of Inferences in Medical Reasoning: a Preliminary Analysis. Paper presented at the Annual Meeting of the American Educational Research Association. Washington, D. C.

Davis, J. S. \& Solomon, I. (1989). Experience, expertise, and expert performance research in public accounting. Journal of Accounting Literature, 8, 150-164.

Dijk, T. A. van \& Kintsch, W. (1983). Strategies of discourse comprehension. New York: Academic Press.

Einhorn, H. J \& Hogarth, R. M. (1981) Behavioral decision theory: processes of judgment and choice. Journal of Accounting Research, 19, 1-41.

Elshout, J. J. (1976). Karakteristieke moellijkheden bij het denken.

Proefschrift. Universiteit van Amsterdam.

Elstein, A. S., Shulman, L. S. \& Sprafka, S. A. (1978). Medical Problem Solving: An Analysis of Clinical Reasoning. Cambridge, MA: Harvard University Press

Ericsson, K. A. \& Crutcher, R. J. (1990). The nature of exceptional performance. In: Baltes, P. B. Featherman D. L. \& Lerner R. M. (Eds.). Lufe-Span Development and Behavior. Vol. 10, 187-217. Hillsdale, NJ: Erlbaum.

Ericsson, K. A. \& Smith, J. (1991). Prospects and limits of the empirical study of expertise: an introduction. In: Ericsson, K. A. \& Smith, J. (Eds.) Toward a General Theory of Expertise; Prospects and Limits. Cambridge, MA: Cambridge University Press

Eriesson, K. A. en Simon, H. A. (1980). Verbal reports as data. Psychological Review, 87, 215-51.

Feltovich, P. J. (1981). Knowledge based Components of Expertise in Medical Diagnosis (Tech. Rep. No. PDS-2). Pittsburgh, PA: University of Pittsburgh Learning Research and Development Center.

Feltovich, P. J. \& Barrows H. S. (1984). Issues of generality in medical problem solving. In: Schmidt, H. G. \& Volder, M. L. (Eds.). Tutorials in Problem-Based Learning; A new Direction in Teaching the Health Professions. Assen: Van Gorcum.

Feltovich, P. J., Spiro, R. J. en Coulson. R. L. (1993). Learning, teaching, and testing for complex conceptual understanding. In: Fredriksen, N., Mislevy, R. en Bejar, I. (Eds.) Test Theory for a new Generation of Tests. Hillsdale, NJ: Erlbaum. 
Fitts P. M. (1964). Perceptual-motor skill learning. In: Melton, A. W. (Ed.). Categories of Human Learning. New York, NY: Academic Press.

Frederick, D. M. (1991). Auditors' representation and retrieval of internal control knowledge. The Accounting Review, 66, 240-258.

Frederick, D. M. \& Libby, R. (1986). Expertise and auditors' judgments of conjunctive events. Journal of Accounting Research, 24, 270-290.

Frederick, D. M., Heiman-Hoffman, V. B. \& Libby, R. (1994). The structure of auditors' knowledge of financial statement errors. Auditing: A Journal of Practice \& Theory. 13, 1-21.

Gilhooly. K. J. (1990). Cognitive psychology and medical diagnosis. Applied Cognitive Psychology, 4, 261-272.

Glaser, R. (1986). On the nature of expertise. In: Klix, F. \& Hagendorf, H. (Eds.). Human Memory and Cognitive Capabilities Mechanisms and Performances. Vol. 2. Amsterdam: Elsevier B.V.

Glaser, R. (1991). The maturing of the relationship between science of learning and cognition and educational practice. Learning and Instruction, 1, 129-144.

Glaser, R. (1995). Discussie naar aanleiding van presentaties over de ontwikkeling van expertise. Gepresenteerd tijdens de jaarlijkse bijeenkomst van de American Educational Research Association te San Francisco, April, 1995.

Groot, A. D. de (1946). Het denken van den Schaker. Den Haag: NorthHolland.

Groot, A. D. de (1965).Thought and Choice in Chess. The Hague: Mouton.

Hamilton, R. E. \& Wright, W. F. (1977). The Evaluation of internal Controls over Payroll. Unpublished Manuscript, Stanford University.

Harris, I. B. (1993). New expectations for professional competence. In: Curry L., Wergin, J. F., \& ass. (Eds.) Educating Professionals. Responding to new Expectations for Competence and Accountability. San Francisco: Jossey-Bass.

Hassebrock, F. en Prietula, M. J. (1992). A protocol coding scheme for the analysis of medical reasoning. International Journal of Man-Machine studies, 37, 613-52.

Hayes, J. R. (1981). The Complete Problem Solver. Philadelphia: Franklin Institute Press. 
Hen, P. E. de, Berendsen, J. G. \& Schoonderbeek, J. W. (1995). Hoofdstukken uit de Geschiedenis van het Nederlandse Accountantsberoep na 1935. Assen: Van Gorcum.

Joyce, E. J. (1976). Expert judgment in audit program planning. Studies on human information processing in accounting. Joumal of Accounting Research, Supplement, 29-60.

Kahneman, D. \& Tversky, A. (1972). Subjective probability: a judgment of representativeness. Cognitive Psychology. 3, 430-454.

Larkin, J. H., McDermott, J., Simon, D. \& Simon, H. A. (1980). Expert and novice performance in solving physics problems. Science, 208, 13351342 .

Lesgold, A., Rubinson, H., Feltovich, P. J., Glaser, R., Klopfer, D. \& Wang, Y. (1988). Expertise in complex skill: Diagnosing X-ray pictures. In Chi, M. T. H., Glaser, R. and Farr, M. (Eds.), The Nature of Expertise. Hillsdale, NJ: Erlbaum

Libby, R. (1982). Accounting and Human Information Processing: Theory and Applications. Englewood Cliffs, NJ: Prentice-Hall.

Libby, R. (1985). Availability and the generation of hypotheses in analytical review. Journal of Accounting Research, 23, 648-667.

Libby , R. \& Frederick, D. M. (1990). Experlence and the ability to explain audit îndings. Joumal of Accounting Research, 28, 348-367.

Minsky. M. A. (1975). A framework for representing knowledge. In: Winston P. H. (Ed.) The Psychology of Computer Viston. New York: McGraw Hill.

Moeckel, C. (1990). The effect of experience on auditors' memory errors. Journal of Accounting Research, 28, 368-387.

Muzzin, J. L., Norman, G. R., Jacoby, L. L., Feightner, J. W., Tugwell, P. \& Gyatt, G. H. (1982). Manifestations of Expertise in Recall of Clinical Protocols. Proceedings of the 21 st Conference on Research in Medical Education. Washington: American Association of Medical Colleges.

Nanni. A. J. (1984). An exploration of the mediating effects of auditor experience and position in internal control evaluation. Accounting. Organizations and Society, 124-145.

Neves, D. M. \& Anderson, J. R. (1981). Knowledge compilation: mechanisms for the automatization of cognitive skills. In: Anderson, J. R. (Ed.), Cognitive Skills and their Acquisition. Hillsdale, NJ: Erlbaum. 
Newell, A. \& Rosenbloom, P. S. (1981) Mechanism of skill acquisition and the law of practice. In: Anderson, J. R. (Ed.) Cognitive Skills and their Acquisition. Hillsdale, NJ: Erlbaum.

Newell, A. \& Simon, H. A. (1972). Human Problem Solving. Englewood Cliffs, NJ: Prentice-Hall.

NIVRA, (1983). Een eeuw te boek, 1 januari 1883 - 1 januari 1983. Honderd jaar accountantsberoep in Nederland. Amsterdam: NIVRA.

NIVRA, (1990). Elementaire kennis Accountantscontrole. Groningen: WoitersNoordhoff B. V.

NIVRA, (1993a). Onderwijsprogramma Belastingrecht I. Cursus, November December 1993. Amsterdarn: NIVRA.

NIVRA, (1993b). Onderwijsprogramma Inleiding in de Bestuurlijke Informatieverwerking. Cursus Januari - Juni 1993. Amsterdam: NIVRA.

NIVRA (1996) Stage-info 1996-1997. Informatiebrochure April 1996. Amsterdam: NIVRA.

Norman, G. R., Brooks, L. R. \& Allen, S. W. (1989). Recall by expert medical practitioners and novices as a record of processing attention. Journal of Experimental Psychology: Learning, Memory and Cognition, 15, 1166. 1174.

Norman, G. R., Jacoby, L. L., Feightner, J. W. \& Campbell, E. J. M. (1979). Clinical experience and the structure of memory. Proceedings of the 18th Annual Conference on Research in Medical Education. Washington, DC.

Patel, V. L. \& Groen, G. J. (1986). Knowledge based solution strategies in medical reasoning. Cognitue Science, 10, 91-116.

Patel, V. L. \& Medley-Mark, V. (1986). Relationship between Representation of Textual Information and underlying Problem Representation in Medicine. (CME Report, CME86-CS1) McGill University: Montreal, Canada.

Rennie M. D., 1991. Auditors' Internal Control System Knowledge: The Role of Mental Models. Audit Judgment Symposium. Los Angeles, CA: University of Southern California, School of Accounting.

Schank, R. C. \& Abelson, R. P. (1977). Scripts, Plans, Goals and Understanding. An Inquiry into Human Knowledge Structures. Hillsdale, NJ: Erlbaum.

Schmidt. H. G. \& Boshuizen, H. P. A. (1993). On the origin of intermediate effects in clinical case recall. Memory \& Cognition, 21, 338-351.

Schōn, D. A. (1987). Educating the reflective practioner: Toward a new design for teaching and learning in the professions. San Francisco: Jossey-Bass. 
Simon, H. A. \& Chase, W. G. (1973). Skill in chess. American Scientist, 61, 394-403.

Spilich, G. J., Vesonder, G. T., Chiesi, H. L. \& Voss, J. F. (1979). Text processing of domain-related information for individuals with high and low domain knowledge. Journal of Verbal Leaming and Verbal Behavior. 18, 275-290.

Starreveld, R. W., Mare, de H. B. en Joěls, E. J. (1991) Bestuurlijke Informatieverzorging, deel 1, Algemene Grondslagen. Alphen aan de Rijn: Samsom.

Stevens H. J. A. (Red.) (1991). Facts en Figures Bouw 1991-1992. Financieeleconomisch brancheboek bouwnijverheid 1991-1992. 's-Gravenhage: Delwel Uitgeverij B. V.

Studiegids (1993/1994). Faculteit der Economische Wetenschappen, Rijksuniversiteit Limburg. Maastricht.

Studiegids (1994/1995). HEAO Windesheim, Christelijke Hogeschool Zwolle. Studiegids NIVRA (1994/1995). Amsterdam: NIVRA.

Tabor, R. H. (1983). Internal control evaluations and audit program revisions: some additional evidence. Journal of Accounting Research, 348-354.

Thorndyke, P. W. \& Hayes-Roth, B. (1979). The use of schemata in the acquisition and transfer of knowledge. Cognitive Psychology. January. 82-106.

Toulmin. S., Rieke, R. \& Janik, A. (1979). An Introduction to Reasoning. New York: Macmillan.

Tubbs, R. (1992). The effect of experience on the auditors' organization and amount of knowledge. The Accounting Review, 67, 783-801.

Tversky, A. (1977). Features of similarity. Psychological Review, 84, 327-352.

Tversky, A. \& Kahneman. D. (1973). Availability: a heuristic for judging frequency and probability. Cognitive Psychology, 5, 207-232.

Tversky, A. \& Kahneman, D. (1974). Judgment under uncertainty: heuristics and biases. Science, 185, 1124-1131.

Vaatstra, R. F., Blommaert, J. M. J., Boshuizen, H. P. A. \& Schmidt, H. G. (1995b). The effect of experience on financial causal knowledge in auditing. Resources in Education, December. (ERIC Document Reproduction Service No. ED 385 193).

Vaatstra, R. F., Boshuizen, H. P. A \& Schmidt, H. G. (1993a). Expertise in Auditing: Case Representation Differences between Economy Students, 
Novice, Intermediate and Expert Auditors. Paper gepresenteerd tijdens de jaarlijkse bijeenkomst van de American Educational Research Association te Atlanta, GA, April, 1993. (ERIC Document Reproduction Service No. ED 362 544).

Vaatstra, R. F., Boshuizen H. P. A. \& Schmidt. H. G. (1993b). Differences in diagnostic accuracy and in the application of knowledge between novice, intermediate and expert auditors. Inter-university Center for Educational Research, Enschede, september, 1993.

Vaatstra, R. F., Boshuizen, H. P. A. \& Schmidt, H. G. (1994). Effecten van ervaring op toepassing van financiële kennis. Onderwijsonderzoek in Nederland en Vlaanderen 1994. Proceedings van de Onderwijsresearchdagen 1994. Universiteit Utrecht, 1994.

Vaatstra, R. F., Boshuizen, H. P. A. \& Schmidt, H. G. (1995a). Differences in the organisation and application of knowledge between novice, intermediate and experienced auditors. In: Gijselaers, W. H., Tempelaar, D. T., Keizer, P. K., Blommaert, J. M., Bernard, E. M. \& Kasper, H. (Eds.) Educational Innovation in Economics and Business Administration. Dordrecht: Kluwer.

Voss, J. F., Greene, T. R., Post, T. A. \& Penner, B. C. (1984). Problem solving skill in the social sciences. In Bower, G. H. (Ed.). The Psychology of Leaming and Motwation (Vol. 18). New York: Academic Press.

Voss, J. F., Tyler, S. W. \& Yengo, L. A. (1983). Individual differences in the solving of social science problems. In Dillon, R. F. \& Schmeck, R. R. (Eds.) Individual Differences in Cognition. New York: Academic Press.

Vries, Joh. de (1985). Geschiedenis der Accountancy in Nederland. Aanivang en Ontplooüng, 1895-1935. Van Gorkum, Assen/Maastricht.

Walker, C. H. (1987). Relative importance of domain knowledge and overall aptitude on acquisition of domain-related information. Cognition and Instruction, 4, 25-42.

Weber, R. (1980). Some characteristics of free recall of computer controls by EDP auditors. Joumal of Accounting Research, 18, 214-241. 
$-164-$ 


\section{Casus Groothandel}

Gros B.V. is een groothandel in huis-, tuin- en keukenbenodigdheden. Onder de tweehoofdige directie een algemeen en een commercieel directeur, die tezamen $63 \%$ van de aandelen houden, ressorteren de volgende afdelingen: administratie met 4 man, inkoop met 14 man, de verkoop met 10 man en het magazijn met 8 man. Binnen de afdeling administratie is 1 persoon belast met debiteurenbeheer. De inkoop vindt voornamelijk plaats op de internationale markt. Hierbij moet rekening worden gehouden met sterke prijs- en valutaschommelingen. Het verkoopgebied strekt zich uit tot de Benelux, Duitsland en Hongarije. Levering vindt voornamelijk plaats aan detallisten en enkele postorderbedrijven. Betaling gebeurt veelal met cheques. De verkoop geschiedt in hoofdzaak telefonisch, waarbij de verkopers tevens zorg dragen voor de order-entry. Er is sprake van een geintegreerde gegevensverwerking voor het verkooptraject, waarbij het principe van voor-facturering wordt toegepast. Voorraden liggen op verschillende locaties. Behalve de magazijnlocatie bij de vennootschap zelf, liggen de goederen bij verschillende transporteurs.

Balans per 31-12-91 (x 1000)

\begin{tabular}{|l|r|r|l|r|r|}
\hline & $\mathbf{1 9 9 1}$ & $\mathbf{1 9 9 0}$ & & $\mathbf{1 9 9 1}$ & $\mathbf{1 9 9 0}$ \\
Inventaris & 800 & 950 & Aandelenkapitaal & 1.000 & 1.000 \\
Voorraden & 6.300 & 5.200 & Reserves & 300 & 300 \\
Debiteuren & 5.800 & 5.300 & Lening & 700 & 870 \\
Liquide middelen & $230 !$ & 20 & Kortlopende & 5.530 & 4.800 \\
& & & Schulden & \\
& 13.130 & 11.470 & Bank & 5.600 & 4.500 \\
& & & 13.130 & 11.470 \\
\hline
\end{tabular}

Verlies-en-Winst rekening $(x$ 1000)

\begin{tabular}{|l|r|r|r|r|}
\hline & $\mathbf{1 9 9 1}$ & & $\mathbf{1 9 9 0}$ & \\
netto omzet & 35.800 & & 31.300 & \\
Kostprijs & $\underline{27.500}$ & & $\underline{23.400}$ & 7.900 \\
Bruto omzet-resultaat & & 8.300 & & \\
Verkoopkosten & 4.300 & & 4.100 & \\
Algemene beheerskosten & 2.200 & & 1.900 & \\
Rentelasten & $\underline{590}$ & & $\underline{440}$ & \\
& & 7.090 & & 6.440 \\
Resultaat voor belasting & & 1.210 & & 1.460 \\
Belastingen & & 485 & & 585 \\
Resultaat na belasting & & 725 & & 870 \\
\hline
\end{tabular}




\section{Casus Bouwonderneming}

Bouw bv is een onderneming die werkzaam is in de sector utiliteit. De algemene leiding van de organisatie berust bij de directeur. Onder de directeur functioneren de volgende afdelingen: bedrijfsbureau, financiêle administratie, automatisering. centrale inkoop, personeelszaken, materieelbeheer en projectleiding. De projectleiding is in financieel en technisch opzicht verantwoordelijk voor de uitvoering van de utiliteitsprojecten. Voor de technische uitvoering wordt de projectleiding bijgestaan door een per project aangewezen uitvoerder. Tevens functioneert per project een werkadministrateur. Regelmatig worden door de afdeling financiêle administratie periode-cijfers opgeleverd. Bij de presentatie van deze cijfers wordt op projektniveau een vergelijking gegeven van begroting en realisatie waarbij materiel verschillen tussen beide grootheden worden geanalyseerd. De voor- en nacalculatie per project is opgebouwd uit materiaalkosten, loonkosten, onderaanneming en toeslagen voor overhead. Tevens zijn de calculaties onderverdeeld naar bouwfasen. Over het algemeen is sprake van projecten welke een zodanige looptijd hebben dat de uitvoering in twee of meerdere boekjaren plaatsvindt. Als waarderingsgrondslag wordt voor de winstbepaling gehanteerd dat winsten naar ratio van de voortgang van de projecten wordt genomen en verlies op het moment van constateren.

Balans per 31-12-91 (x 1000)

\begin{tabular}{|c|c|c|c|c|c|}
\hline & 1991 & 1990 & & 1991 & 1990 \\
\hline Gebouwen & 1.000 & 1.100 & Geplaatst kapitaal & 500 & 500 \\
\hline Materieel & 1.500 & 1.600 & Winstreserves & 4.620 & 4.300 \\
\hline Onderhanden werk & 8.000 & 7.500 & $\begin{array}{l}\text { Backservice } \\
\text { pensioen }\end{array}$ & 270 & 330 \\
\hline Voorraden & 100 & 80 & $\begin{array}{l}\text { Garantie } \\
\text { voorziening }\end{array}$ & 450 & 420 \\
\hline Debiteuren & 5.500 & 5.200 & $\begin{array}{l}\text { Langlopendle } \\
\text { schulden }\end{array}$ & 4.700 & 5.000 \\
\hline Overige vorderingen & 750 & 650 & $\begin{array}{l}\text { Gefactureerde } \\
\text { termitinen. }\end{array}$ & 7.000 & 6.400 \\
\hline Liquide Middelen & 1.200. & $\underline{1.100}$ & $\begin{array}{l}\text { Belastingen \& } \\
\text { premies }\end{array}$ & 280 & 150 \\
\hline & 18.050 & 17.230 & Overige schulden & 18.050 & 17.230 \\
\hline
\end{tabular}


Verlies-en-Winst rekening $(\mathrm{x}$ 1000)

\begin{tabular}{|c|c|c|c|c|}
\hline & 1891 & & 1990 & \\
\hline Netto omzet & 30.200 & & 29.700 & \\
\hline $\begin{array}{l}\text { Mutatie } \\
\text { onderhanden werk }\end{array}$ & 300 & & 100 & \\
\hline $\begin{array}{l}\text { Produktiekosten } \\
\text { materiaal }\end{array}$ & 4.200 & 30.500 & 6.800 & 29.800 \\
\hline Werk derden & 21.900 & & 18.300 & \\
\hline Loonkosten & 3.200 & & 3.100 & \\
\hline Dekking Overhead & 840 & 30.140 & 780 & 28.980 \\
\hline $\begin{array}{l}\text { Resultaat voor } \\
\text { belasting }\end{array}$ & & 360 & & 820 \\
\hline Belastingen & & 110 & & 350 \\
\hline $\begin{array}{l}\text { Resultaat na } \\
\text { belasting }\end{array}$ & & 250 & & 470 \\
\hline
\end{tabular}

\section{Casus 8tichting}

De stichting "Ons kasteel" exploiteert een kasteel met de daarbij behorende kasteeltuinen waarin ondermeer een botanische tuin is aangelegd. Het kasteel en de tuinen, zijn voor het. publiek opengesteld. De toegangsprijzen worden door het bestuur vastgesteid, te weten een tarief voor volwassenen en een tarief voor kinderen., Voor houders van $65+$ pas geldt een korting. Het bestuur van de stichting bestaat uit vijf leden. De stichting heeft een beheerder in dienst die leiding geeft aan vijf gardeniers, vier horecamedewerkers, vier medewerkers van de huishoudelijke-technische dienst en de administrateur met twee administratieve medewekers. In het kasteel bevindt zich een horecagedeelte waar maaltijden en aanverwante horeca-artikelen worden gereserveerd tegen door het bestuur vastgestelde prijzen. Die zalen van het kasteel worden verhuurd aan derden tegen door het bestuur vastgestelde tarieven. In de zomermaanden is de bezetting bijna $100 \%$. In de wintermaanden is de verhuur van zalen aanmerkelijk minder. De stichting ontvangt subsidie op basis van de "rijksregeling kastelen". De personele kosten worden voor $40 \%$ gesubsidieerd, de afschrijvingen op vaste activa voor $50 \%$ en de huisvestings- kosten voor $60 \%$. Het bestuur stelt jaarlijks een begroting vast. 
Balans per 31-12-91 (x 1000)

\begin{tabular}{|l|r|r|l|r|r|}
\hline & 1991 & 1990 & & 1991 & 1990 \\
Bedrijfsgebouwen & 3060 & 2300 & Algemene Reserves & 480 & 400 \\
en terreinen & 320 & 470 & Voorziening & 340 & 320 \\
Andere vaste activa & 130 & 120 & Leningen & 2700 & 2170 \\
Voorraden & 680 & 425 & Rekening Courant & 230 & 120 \\
Vorderingen & $\mathbf{3 7 0}$ & $\mathbf{4 1 0}$ & Kortlopende & $\underline{810}$ & $\mathbf{7 1 5}$ \\
Liquide Middelen & 4560 & 3725 & Schulden & 4560 & 3725 \\
& & & \\
\end{tabular}

Verlies-en-Winst rekening (x 1000)

\begin{tabular}{|l|r|r|l|r|r|}
\hline Kosten & $\mathbf{1 9 8 1}$ & $\mathbf{1 9 9 0}$ & Opbrengsten & $\mathbf{1 9 9 1}$ & $\mathbf{1 9 9 0}$ \\
Inkopen Horeca & 460 & 290 & Horeca omzet & 925 & 975 \\
Personeelskosten & 1070 & 1060 & Entrees & 400 & 400 \\
Huisvestingskosten & 375 & 625 & Huren & 390 & 390 \\
Afschrijvingskosten & 180 & 160 & Subsidies & 740 & 790 \\
Rente & 190 & 220 & Diverse Baten & $\underline{40}$ & $\underline{40}$ \\
Batig saldo & 220 & $\underline{240}$ & & & \\
& 2495 & 2595 & & 2495 & 2595 \\
\hline
\end{tabular}




\section{Andachtopunten Groothandel}

Directeuren in bezit yan $63 \%$ van de aandelen

Inkoop: prijs- en valutaschommelingen

Verkoop: Hongarije is politiek onstabiel

Betalen met cheques

Voorraad ligt bij groothandel en transporteurs

Geintegreerde orderverwerking door verkopers

Slechts 1 persoon verantwoordelijk voor debiteuren.

Verhouding Eigen Vermogen tot Vreemd Vermogen is slecht

Voorraden te hoog: incourant

Winst is volledig uitgekeerd aan aandeelhouders

Liquide middelen zijn hoog, gezien de kredietomvang,

\section{Andachtspunten Bouwonderneming}

Meerjarige projekten

Winstneming naar rato

Verschillen in voor- en nacalculatie

Afstemming financięle administrateur en werkađminlstrateur

Gefactureerde termijnen worden eerder gefactureerdi dan zou moeten.

Onderaanneming omvangrijk

Mutatie Onderhandenwerk in Balans komt niet overeen met mutatie Onderhandenwerk in

Verlies-en-Winst rekening

Produktiemateriaal daalt terwijl omzet hoger is

Werk derden relatief sterk gestegen in relatie tot stijging netto omzet

Onderhandenwerk is in verhouding tot de omzet laag 


\section{Aradachtopunten 6tichting}

Toegangskaarten, verschillende prijzen

Horeca, opbrengsten niet opgeven

Ingrediènten in eigen zak steken

Verhuuropbrengsten

Seizoensinvloeden: risicovol

Verschuiving van subsidies

Geinvesteerd in gebouwen

Vorderingen relatief hoog

Rente gedaald, maar leningen en schulden zijn gestegen

Personeelskosten zijn hoog

Bevoegdheden (functiescheiding) bestuursleden 


\section{Oefencasus 30}

Hout BV is gevestigd in Zwolle.

Zij is opgericht in 1927.Vestigingen in Nederland. Direktie: P. de Boer (60 jaar).

Commissarissen: Prof. Dr. P.L. Jansen en Ir. K. Visser.

Aandelenkapitaal: Het maatschappelijk kapitaal bedraagt $\mathrm{f}$. 350.000 .

Het bestaat geheel uit gewone aandelen.

Per ultimo boekjaar bedroeg het geplaatst en gestort kapitaal fl. 300.000 .

Hout B.V. is de houdstermaatschappij van een groep bedrijven die aktiviteiten ontplooien in de houtsektor.

Verlies en Winstrekening ( $x$ 1000)

\begin{tabular}{|l|r|r|}
\hline & 1990 & $\mathbf{1 8 8 9}$ \\
Bedrijfsresultaat & 603 & -559 \\
Res. voor belasting & -45 & -1.028 \\
Res. na belasting & 72 & -965 \\
Groepsresultaat & 346 & -1.510 \\
Res. aandeelhouders & 346 & -1.510 \\
\hline
\end{tabular}

Balans (x 1000)

\begin{tabular}{|l|r|r|}
\hline & $\mathbf{1 9 9 0}$ & $\mathbf{1 9 8 9}$ \\
Vaste aktiva & 13.11 .7 & 12.735 \\
Vlottende aktiva & 12.927 & 17.955 \\
Eigen Vermogen & 10.837 & 10.491 \\
Voorzieningen & 2.903 & 3.796 \\
Schuld lange termijn & 5.114 & 4.236 \\
Kortlopende schulden & 7.180 & 12.167 \\
& & 30.690 \\
\hline
\end{tabular}

\begin{tabular}{|l|r|r|}
\hline & $\mathbf{1 9 9 0}$ & $\mathbf{1 9 8 9}$ \\
Netto omzet & 52.245 & 43.340 \\
Personeelskosten & 1.007 & 1.389 \\
Aansprak.vermogen & 9.183 & 1.296 \\
Werkzaam vermogen & 9.183 & 2.052 \\
Werkkapitaal & 5.747 & 5.788 \\
\hline
\end{tabular}

30 Casus zifn afgeleld uit Stevens (Red.). Facts \& Figures Bouw 1991-1992. 


\section{Casus 1}

Van Dijk Bouwgroep BV is gevestigd in Twello.

Zij heeft vestigingen in Nederland.

De bankier: ABN/AMRO N.V.

Het accountantskantoor: Bonsen \& Reuling Accountants.

De direktie: G.M.J. Gerritsen (1945), E.J.J.H. Wezenberg (1946).

Raad van Commissarissen: G.F. van Dijk (1925). J.G.A. van Dijk (1924).

Aandelenkapitaal: Het maatschappelijk kapitaal bedraagt 2 miljoen.

Hiervan is geplaatst en gestort 1.5 miljoen.

Deelnemingen:Van Dijk Bouwmaatschappij B.V. te Twello (meerd.)

Van Dijk Sport/Rekreatiebouw B.V. te Twello (meerd.)

Bouwbedrijf Chris Dijkstra B.V. te Zutphen (meerd.)

De geschiedenis van de Van de Belt Bouwgroep B.V. te Twello gaat terug tot het jaar 1896.

Door de jaren heen is het bedrijf uitgegroeid van een regionaal aannemingsbedrijf naar een sterk landelijk opererende onderneming. Thans is Van Dijk Bouwgroep B.V. houdstermaatschapp!j van een drietal werkmaatschappijen. Van Dijk Bouwmaatschappij B. V., Van Dijk Sport/Rekreatiebouw B.V. en Bouwbedrijf Chris Kappert B.V. Dochteronderneming Van Dijk Bouwmaatschappij B.V. ontplooit aktiviteiten op het gebied van utiliteitsbouw, woningbouw en renovatie van utiliteits- en woningbouw. Het bedrijf realiseert onder meer gebouwen voor de gezondheidszorg, scholen, bedrijfshuisvesting, winkelcentra, kantoren en banken. Daarnaast wordt Van Dijk Bouwmaatschappij B.V. ingeschakeld voor de realisatie van projekten voor (overheids)instellingen en projekten ten behoeve van milieu en energie. Voor snelle reparaties dan wel verbouwingen heeft de onderneming een "after-sales" service-dienst in het leven geroepen. Van Dijk Sport/Rekreatiebouw B.V, ontwerpt, bouwt en. installeert onder andere openlucht- en overdekte rekreatieve zwembaden, therapeutische baclen. sportzalen, bungalowparken. maneges, totale rekreatieprojekten, evenementenhallen, sauna's, bibliotheken en wijkcentra. Daarnaast realiseert het bedrijf renovatie-projekten en worden uitbreidingen en verbouwingen uitgevoerd. Van Dijk Sport/Rekreatiebouw B.V. beschikt over deskundigen op het gebied van waterzuivering, klimaatbeheersing, energiebesparing, verlichting, konstruktie en bouwfysica. 
- Bylage 3 -

Verlies-en- Winst rekening (x 1000)

\begin{tabular}{|l|r|r|r|r|}
\hline 01-01/31-12 & $\mathbf{1 9 9 0}$ & $\mathbf{1 9 8 9}$ & $\mathbf{1 9 8 8}$ & $\mathbf{1 9 8 7}$ \\
Bedrijfsopbrengsten & 30.472 & 37.487 & 35.264 & 32.705 \\
Bedrijfslasten & 30.180 & 36.863 & 34.666 & 32.371 \\
Bedrijfsresultaat & 292 & 624 & 598 & 334 \\
Fin. Baten & 143 & 164 & 113 & 55 \\
Fin. lasten & 0 & 0 & 0 & 0 \\
Res. voor belasting & 435 & 788 & 711 & 389 \\
Res. na belasting & 251 & 541 & 503 & 238 \\
Bijzondere baten & 0 & 0 & 0 & 0 \\
Bijzondere lasten & 0 & 0 & 0 & 0 \\
Belasting bljz. res. & 0 & 0 & 0 & 0 \\
Groepsresultaat & 251 & 541 & 503 & 238 \\
Res. voor stat. uitk. & 251 & 541 & 503 & 238 \\
Res, aandeelhouders & 251 & 541 & 503 & 238 \\
\hline
\end{tabular}

Balans (x 1000)

\begin{tabular}{|l|r|r|r|r|}
\hline 01-01/31-12 & $\mathbf{1 9 9 0}$ & $\mathbf{1 9 8 9}$ & $\mathbf{1 9 8 8}$ & $\mathbf{1 9 8 7}$ \\
Imm. vaste aktiva & 0 & & 0 & 0 \\
Mat. vaste aktiva & 2.802 & 2.919 & 2.661 & 2.378 \\
Fin. vaste aktiva & 0 & 200 & 0 & 0 \\
Vlottende aktiva & 9.369 & 6.348 & 7.062 & 7.304 \\
Eigen Vermogen & 2.052 & 2.013 & 1.472 & 876 \\
Egal. rek. WIR premie & 36 & 66 & 104 & 123 \\
Voorzieningen & 492 & 764 & 692 & 1.087 \\
Schuld lange termijn & 0 & 0 & 0 & 0 \\
Kortlopende schulden & 9.591 & 6.624 & 7.455 & 7.844 \\
Balanstotaal & 12.171 & 9.467 & 9.723 & 9.930 \\
\hline
\end{tabular}

Medewerkers gemiddeld

Personeelskosten

Cash-flow

Investeringen

Aansprakelijk vermogen

Rentedr. vreemd vermog.

Werkzaam vermogen

Werkkapitaal

\begin{tabular}{|r|r|r|r|}
\hline $\mathbf{1 9 9 0}$ & $\mathbf{1 9 8 9}$ & $\mathbf{1 9 8 8}$ & $\mathbf{1 9 8 7}$ \\
5 & 5 & 5 & 5 \\
2.180 & 1.874 & 1.903 & 1.720 \\
887 & 1.054 & 1.175 & 806 \\
145 & 11 & 344 & 1.630 \\
2.478 & 2.687 & 2.133 & 1.915 \\
353 & 0 & 0 & 0 \\
2.933 & 2.843 & 2.268 & 2.086 \\
-222 & -276 & -393 & -540 \\
\hline
\end{tabular}




\section{Casus2}

Baggermaatschappl] Bagger B.V. is gevestigd in Hardinxveld-Giessendam.

Zij heeft vestigingen in Belgiê, Denemarken, Frankrijk, Groot-Brittanniē, Ierland, Israēl, Nederland en Spanje.

De Bankier is ABN/AMRO N.V.

Het accountantskantoor: Deloitte \& Touche.

De direktie: Ir. A.A. van Beek (1932), Ir J.J. Scheele (1958), Ing. P, van der Vlies (1942), Ing J. van Zandbergen (1938).

Raad van Commissarissen: Prof. Dr. L.H. Klaassen (1920) (voorzitter). Ir. A.G. Penning (1923) (waarnemend voorzitter), A. Krakeel (1923), Ing. H.T. Scheele (1956) en

L.J.P. de Waal (1946).

Aandelenkapitaal: het maatschappeljk kapitaal bedraagt fl. 2,8 miljoen.

Hiervan is geplaatst en gestort f. 596.800, bestaande uit f. 16000 prioriteitsaandelenkapitaal en $\mathbf{0} . \mathbf{5 8 0 . 8 0 0}$ gewoon aandelenkapitaal.

Deelnemingen: V.o.f. Deltaklei te Hardinxveld-Giessendam (25\%),

Pijplijn B.V. te Papendrecht (meerd.)

Wijnands Werkendam B.V. te Werkendam (meerd.).

Baggermaatschappij Bagger B.V. is de houdstermaatschapply van een aantal nationale en Internationale ondernemingen.

Deze houden zich bezig met het verrichten van bagger-, haven-, water-, grond- en wegenwerken, alsmede met het leggen van pijpleidingen.

Zo 18 het bedriff onder meer betrokken geweest bij diverse projekten op het gebied van landwinning, havenuitbreiding en dijk- en damverhoging.

In Nederland ressorteren onder Baggermaatschapplj Holland B.V. de werkmaatschappij en Pijplijn B.V. en Wijnands Werkendan B.V.

Pijplijn B.V. die in 1980 werd opgericht, is gespectaliseerd in het aanleggen van pijpleidingen en het verrichten van daarmee samenhangende werkzaamheden.

Wijnands Werkendam B.V. werd in 1973 verworven, teneinde de capaciteit op het gebied van oeverbescherming te vergroten.

Naast de Nederlandse ondernemingen beschikt Baggermaatschappij Holland B.V. over zeven ondernemingen in Belgiě, Denemarken. Frankrijk, Groot-Brittanniě, Ierlanđ, Israēl en Spanje.

Deze buitenlandse ondernemingen beschikken evenals de Nederlandse over een uitgebreide vloot materieel. 
- Bylage 3 .

Verlies-en-Winstrekening ( $x$ 1000)

\begin{tabular}{|l|r|r|r|r|}
\hline 01-01/91-12 & $\mathbf{1 9 8 0}$ & $\mathbf{1 9 8 9}$ & $\mathbf{1 9 8 8}$ & $\mathbf{1 9 8 7}$ \\
Bedrijfsopbrengsten & 34.833 & 32.153 & 58.953 & 54.854 \\
Bedrijfslasten & 34.081 & 29.491 & 56.783 & 52.220 \\
Bedrijfsresultaat & 752 & 2.662 & 2.170 & 2.634 \\
Fin. Baten & 1.216 & 370 & 373 & 567 \\
Fin. lasten & 346 & 392 & 466 & 688 \\
Res. voor belasting. & 1.622 & 2.640 & 2.077 & 2.513 \\
Res. na belasting & 1.571 & 2.524 & 1.983 & 1.923 \\
Bijzondere baten & 0 & 0 & 0 & 0 \\
Bijzondere lasten & 0 & 0 & 0 & 0 \\
Belasting bijz. res. & 0 & 0 & 0 & 0 \\
Groepsresultaat & 1.571 & 2.524 & 1.983 & 1.923 \\
Res. voor stat. uitk. & 1.571 & 2.524 & 1.983 & 1.923 \\
Stat. uitkeringen e.d. & 79 & 116 & 78 & 75 \\
Res. aandeelhouders & 1.492 & 2.408 & 1.905 & 1.848 \\
\hline
\end{tabular}

Balans (x 1000)

\begin{tabular}{|l|r|r|r|r|}
\hline 01-01/31-12 & $\mathbf{1 9 9 0}$ & $\mathbf{1 9 8 9}$ & $\mathbf{1 9 8 8}$ & $\mathbf{1 9 8 7}$ \\
Mat. vaste aktiva & 37.583 & 33.726 & 35.979 & 45.522 \\
Fin. vaste aktiva & 331 & 1.428 & 1.437 & 1.576 \\
Vlottende aktiva & 37.598 & 21.447 & 17.700 & 38.636 \\
& & & & \\
Eigen Vermogen & 26.714 & 25.222 & 23.025 & 21.074 \\
Egal. rek. WIR premie & 2.227 & 2.670 & 2.908 & 5.162 \\
Voorzieningen & 7.464 & 8.334 & 12.151 & 14.507 \\
Schuld lange termijn & 6.153 & 4.832 & 5.738 & 11.563 \\
Kortlopende schulden & 32.954 & 15.543 & 11.294 & 33.428 \\
Balanstotaal & 75.512 & 56.601 & 55.116 & 85.734 \\
\hline
\end{tabular}

Medewerkers gemiddeld Personeelskosten

Cash-flow

Investeringen

Aansprakelijk vermogen

Rentedr, vreemd vermog.

Werkzaam vermogen

Werkkapitaal!

\begin{tabular}{|r|r|r|r|}
$\mathbf{1 9 9 0}$ & $\mathbf{1 9 8 9}$ & $\mathbf{1 9 8 8}$ & $\mathbf{1 9 8 7}$ \\
148 & 123 & 148 & 140 \\
13.783 & 10.759 & 11.634 & 12.135 \\
6.979 & 7.832 & 7.994 & 9.151 \\
8.242 & 3.162 & -3.606 & 2.859 \\
28.941 & 27.892 & 25.933 & 26.236 \\
6.728 & 5.270 & 6.1651 & 4.450 \\
43.133 & 41.496 & 44.249 & 55.193 \\
4.644 & 5.904 & 6.406 & 5.208 \\
\hline
\end{tabular}


$-176-$ 


\section{Vragen en antwoorden Casus Bagger BV}

1. Hoe kan het dat er in 1990 sprake is van een negatieve investering?
A) Er zijn meer desinvesteringen dan investeringen in activa (5)
B) Materiêle vaste activa verkocht (3)
C) Vlottende activa afgenomen (2)
D) Financiêle activa gedaald (2)

2. Hoe kan het dat de omzet van 1991 is gedaald, terwijl het groepsresultaat is gestegen.
A) Bedrijfslasten nemen af (2)
B1) Een belangrijk deel van de bedrijfslasten bestaan uit het varlabele kosten (10)
B2) Personeelskosten (1)
B3) afname werknemers (1)
B4) efficiêntere produktie (1)
B5) Kostprijs verkopen daalt (1)
D) Bedrijfsresultaat is per saldo gestegen (2)
E) Verliesgevende actuviteit afgestoten (5)

3. Wat kun je opmerken m.b.t. de verschillen die in een bepaald jaar bestaan tussen resultaat voor en het resultaat na belasting?
A) Blelastingen in het begin hoog later minder hoog (1)
B) Het verschil moet veel groter zijn, zo'n 35 a $40 \%$ (2)
C) Financięle baten minder belast (4)
D) Het is een relatief klein bedrag, dat ten laste van het commercięle (bedrijfseconomische) resultaat is gelegd (6)

E) Er zijn veel permanente verschillen en/of veel positief tujdelijke verschillen waardoor er relattief grote bedragen ten laste van voorzieningen voor belastingen zijn gebracht (8)

F) Tevee! betaald in eerdere jauren, wat leidt tot verlaging in latere jaren, aanspreking voorziening (10).

4. Wat kun je zeggen van de fluctuaties in het balanstotaal in relatie tot fluctuaties in de omzet?
A) Balansstijging/ daling is pas 1 jaar later in Verlies-en-Winstrekening te zien (5)
B) Bedrijf anticipeert op toekomst, er zal waarschijnlijk sprake zijn van een positieve. ontwikkeling in '92 (10).


5. Schets het verband tussen de veranderingen in werkkapitaal ten opzichte van de veranderingen in omzet.

A) $\mathrm{Er}$ is minder verkocht, dus minder aan debiteuren, daarom daalt netto-werkkapitaal (=vlott activa-vlott passiva) (5)

B) $\mathrm{Er}$ is minder verkocht en daardoor minder geproduceerd, dus minder voorraden en ook lagere schulden (5).

6. Hoe kan het dat er een stijging van personeelsleden en personeelskosten is, terwijl de omzet gelijk blijft.

A) Duurder personeel (1), Ondersteunend personeel (1), Meer overheaduren (1). Arbeidstijdverkorting (1), Daling verkoopprijzen (1), Concurrentiestrijd (1)

B) Voorraden geproduceerd, maar nog niet verkocht (4)

C) Het bedrijf bereidt zich voor op positteve ontwikkelingen (10)

7. Stel je moet een schatting maken van de omzet over 1993. In welke range zou je schatting dan uitkomen?

Minder dan 20.000/20.000-30.000/30.000-40.000/40.000-50.000 of meer dan 50.000

Geế een zo duidelijk mogelijke toelichting voor je keuze.
A) Gemiddelde van de omzet van cle vorige jaren (2)
B) Op basis van. balanstotaal (4)
C) Op basis van personeelsleden (4)
D) In '92 finke Investeringen gedaan, waar ze in '93 van profiteren (4)
E) Hoog Kort Vreemd Vermogen in '92, ze verwachten dus in '93 een hoge omzet (4).

8. Welk verband bestaat er tussen de cash-flow en de investeringen?

A) Investeringen worden gefinancierd met de cash flow $=$ winst + afschrijvingen. Dus als de cash flow groter is dan de investeringen, kan er vermogen worden afgelost (10)

B) Hoe hoger de investeringen, hoe lager de cash flow (4)

C) Investeringen kunnen in de toekomst aanleiding geven tot een hogere cash-flow, omdat er waarschijniljk meer winst/ afschrijvingen gerealiseerd gaan worden (6).

9. Geef een zo duideljk mogelijke verklaring voor de toename van de financiêle baten, terwijl de financięle vaste activa zijn afgenomen.
A) Deelnemingent verkocht met "gigantische" boekwinst, dat leidt tot hoge baten (6)
B) Verkoop verliesgevende deelneming, de baten worden niet langer gedrukt (6)
C) Toename interest percentage (4)
D) Toename verkregen dividend (4)
E) Capital gains op verkochte financiêle vaste activa (4) 
10. Geef verklaring voor de relatief sterke toename van de kortlopende schulden in ' 92 , terwijl de financiêle lasten in dat jaar zijn afgenomen?"

A) Een groot deel bestaat uit niet rente dragend vreemd vermogen (4)

B) Onder Kort Vreemd. Vermogen bevinden zich termijnen van onderhanden werken waarover geen interest is betaald (4)

C) Rentepercentage moet verlaagd zijn (2)

D) Op oude leningen moet ook het rentepercentage verlaagd zijn en/of de oude leningen moeten zijn omgezet in nieuwe leningen (2)

E) De kortlopende schulden zijn pas tegen het eind van het jaar opgenomen en hebben nog geen of weinig effect gehad op de rentelasten van dat jaar (4). 
-180 - 
Bij het tot stand komen van dit proefschrift zijn een aanzienlijk aantal mensen van belang geweest. Allereerst wil ik mijn (co)promotoren Els Boshuizen, Henk Schmidt en Arnold Schilder bedanken voor de tijd en energle die ze in de begeleiding gestoken hebben. Els Boshuizen heeft daarbij de meeste uren in de begeleiding gestoken. Zij stond voortdurend klaar om problemen op te lossen en kritisch mee te denken over het verloop van het project. Henk Schmidt bedank ik voor het feit dat hij mij op de juiste momenten heeft gestimuleerd en gemotiveerd. De rode draad verloor hij daarbij nimmer uit het oog. Arnold Schilder wil ik bedanken voor de wijze waarop hij mij heeft bijgestaan bij het overbruggen van de kloof tussen het cognitief psychologisch domein en het accountancy veld. Wim Gijselaers, die nauw betrokken was bij de opzet van het project, dank tk voor zijn waardevolle adviezen.

De leden van de beoordelingscommissie wil $\mathrm{ik}$ bedanken voor hun opmerkingen en adviezen om het manuscript te verbeteren.

Verder ben ik vele medewerkers van de sectie Berichtgeving en van de Postdoctorale Opleiding Accountancy van de Universiteit Maastricht erkentelijk voor hun ondersteuning. Met name Wim Aibers, Hans Bijvoet, Jos Blommaert, Roger Dassen, Ad Marneffe, Eddy Vaassen en Jacques Vermeer waren onmisbaar bij het ontwikkelen van het casusmateriaal. Rolf Wenemoser en Desy Mercks wil $\mathrm{k}$ bedanken voor het felt dat zij als tweede beoordelaar hebben willen optreden. Docenten van de postdoctorale opleiding ben ik erkentelijk voor het feit dat zij mij altijd de gelegenheid hebben gegeven om tijdens hun onderwijsbijeenkomsten postdoctorale studenten te werven voor de empirische studies. Dankzij de inzet van Mark Gullkers, Harold Hassink, Steven Majoor en Luc Quadackers was het mogelijk om voldoende vierdejaars accountancystudenten te werven voor het derde en tevens laatste onderzoek.

Miranda van der Boorn. Sabine Galama, Ilse Gronenschild en Sonja Passau bedank $\mathrm{ik}$ voor hun assistentie bij het registreren van accountancystudenten die deelnamen aan de onderzoeken.

Niet alleen medewerkers van de Universiteit Maastricht hebben overigens hun ondersteuning verleend. Ook Ger Karreman en Tullie Schmidt 
van het NIVRA en het secretariaat van de vakgroep Accountancy en Recht van de Universiteit van Amsterdam ben ik erkentelijk voor hun medewerking.

Uiteraard zou dit proefschrift niet gerealiseerd zijn als de proefpersonen niet hadden meegewerkt aan de onderzoeken. Alle deelnemende studenten en registeraccountants wil ik daarvoor bedanken.

Cathy Nagelkerke ben $1 \mathrm{k}$ erkentelijk voor haar commentaar op de Engelse samenvatting.

Verder wil $\mathrm{k}$ mijn directe collega's van de vakgroep Onderwijsontwikkeling \& Onderwijsresearch bedanken voor de prettige samenwerking. Met name Erik Driessen, Jeannette Hommes, Cita van Til en Margje van de Wiel dank ik hartelijk voor het contact dat zij met me hielden gedurende de tijd dat $\mathrm{k}$ in het noorden vertoefde.

Drie vriendinnen verdienen het zeker hier genoemd te worden. Petra de Maar die in ijltempo tekstuele correcties heeft uitgevoerd, Jannie Damstra die op professionele wijze de omslag en de uitnodigingen heeft vormgegeven en Saskia van der Lyke wier gastvrijheid nagenoeg een jaar mocht duren.

Tenslotte wil ik John Dijkstra bedanken voor de emotionele steun die hij heeft verleend bij deze omvangrijke klus.

Maastricht, oktober 1996. 
Rina Vaatstra werd op 30 augustus 1963 geboren te Leeuwarden. Zij voltooide haar VWO-opleiding in 1982 aan de Rijksscholengemeenschap 'Simon Vestdijk' te Harlingen. Na één jaar Agogische Academie heeft ze cle overstap gemaakt naar Psychologie aan de Rijksuniversiteit Groningen. In 1989 studeerde zij af in de Funktieleer. Na haar studie heeft zij in een academische boekhandel gewerkt, waarnaast zij cursussen volgde op het gebied van bedrijfskunde. In 1991 werd zij AIO bij de vakgroep Onderwijsontwikkeling en Onderwijsresearch ten behoeve van de Faculteit der Economische Wetenschappen en Bedrijfskunde van de Universiteit Maastricht. Sinds oktober 1996 is zij daar werkzaam als universitair docent op het gebied van docentenprofessionalisering en het vaardigheidsonderwijs. 


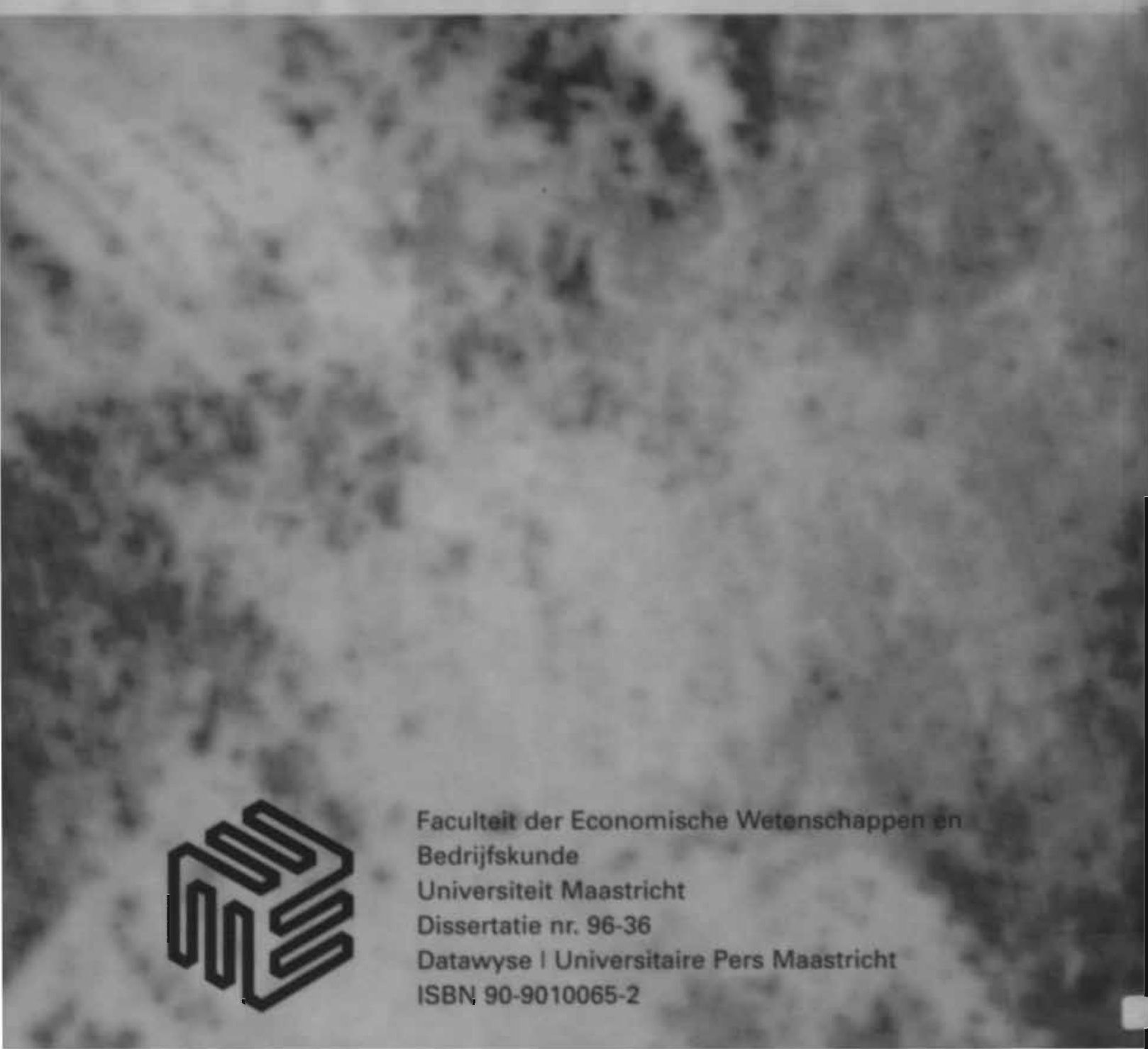

